\title{
الاستقلال بين \\ العلاقات التجارية المرتبطة
}

\author{
shel
}

أ.د / حسام رضا السيد عبدالحميد

أستاذ القانون التجاري والبحري المساعد

كليتتالحقوق - جامعت عين شمس 


\section{هبحث تههيدي}

\section{استقلال شرط التمكيم كوسيلة لفض المنازعات الناشئة}

\section{عن العلاقات التجارية المرتبطة}

فكرنا عند إعداد خطة هذا البحث أن نفرد فصلاً مستقلًا لاستقلال شرط التحكيم عن العقد الأصلي، ليكون فصلاً رابعاً إلى جانب الفصول الثلاثة التي تناولنـا في الأول منها استقلال الالتزام الصرفي في الورقة التجاريـة، وفي الثاني استقلال الأمـة الماليـة

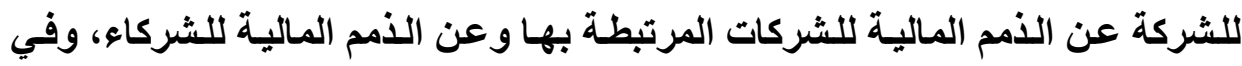
الثالث استقلال التزام البنك بلفع قيمة الاعتماد المستندي وخطاب الضمان. إلا أنتا عدلنا

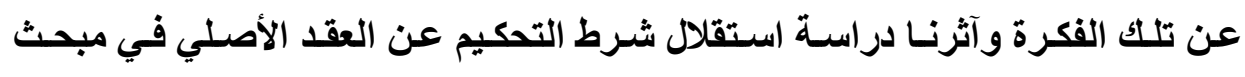

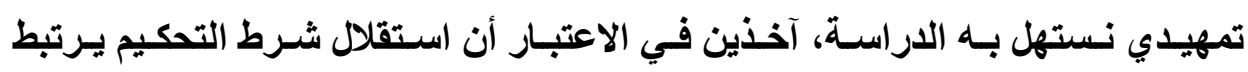

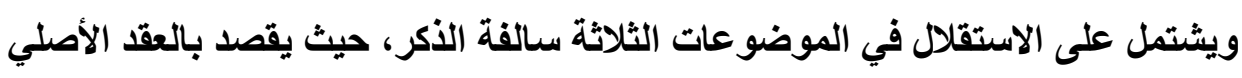

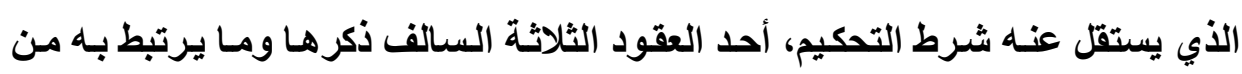
عقود أخرى. فقد يكون هذا العقد هو الورقة التجارية وما يرتبط بها من علاقة الأسـاس والعلاقـات بين المظهرين المتعاقبين وتلك التي تشتمل عليها الوراقة ذاتها (')، وقد يكون عقد الأساس في العمليات المصرفية الأي ترتبط بها العلاقات الأخرى التي تثتمل

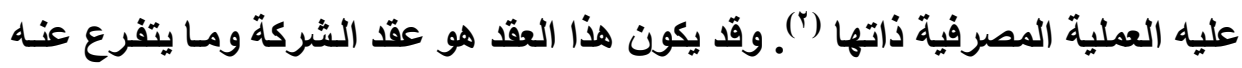

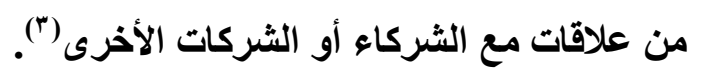

( (1) د. راجح فؤاد العيد مصبح، التحكيم في الأوراق التجارية، دراسة مقارنة، رسالة دكتوراه، حقوق

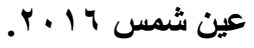

(r) د. رضـا السيد: مسائل في التحكيم ـ التحكيم في الكفالـة المصرفية وخطاب الضمان، طبعة r ا ب. Y، صده وما بعدها.

(3) D. Cohen. Arbitrage Et Société, Preface, R. Oppétit. L. G. D. J. 1993. 
فدراسـة استقلال شرط التحكيم، إذا اتفق على التحكيم للفصل في المنازعـات

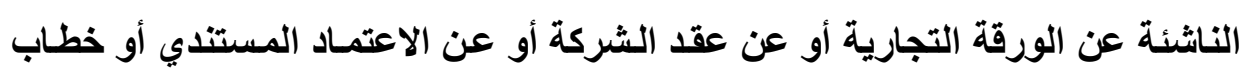

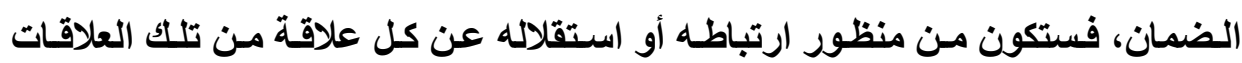

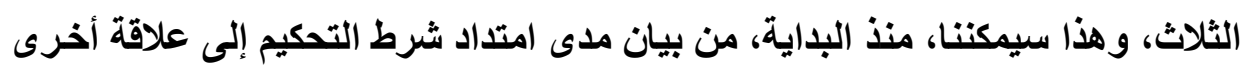
لم يرد النص عليه فيها أو انتقاله من علاقة إلى علاقة أخرى. وهناك مجموعة من المصطلحات تستعمل في مجال استقلال شرط التحكيم، قد يختلط المقصود منها ببعضه البعض، لذا لزم تحديد معنى كل منها (المطلب الأول)،

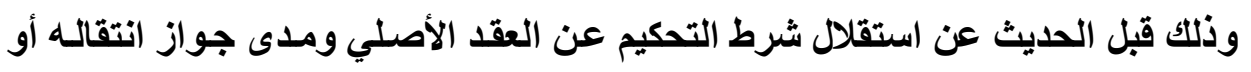
مده من عقد إلى آخر (المطلب الثاني).

\section{الاطبا الأول}

\section{ضبط الاصطلاحات في همال شرط التمكيم}

قـ يستعمل مـصطلح "اسـتقلال شـرط التحكيم أو انفصاله(') (الفرع الأول) أو

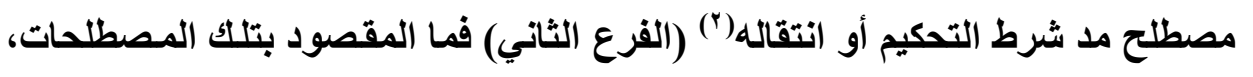

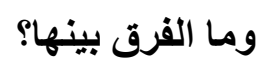

(1) Pierre MAYER, les limites de la séparabilité de la clause compromissoire, Rev. arb. 1998. p. 359 etss.

(2) Eric LOGUIN, tribunaux de commerce et arbitrage, de la transmission et de l'extension de la clause compromissoire, RTD. Com. 2007, p. 677 et 55 . 


\section{الفرع الأول}

\section{استقلال شرط التمكيم وانفصاله}

قد يرد شرط التحكيم في العقد الأصلي فيكون مستقلاً عنه (أولاً)، وقد يرد في مستند مستقل عن العقد الأصلي فيكون منفصلاً عنه (ثانياً).

أولاً: استقلال شرك التحكيم: Autonomie

قد يرد شرط التحكيم كبند من بنـود العقد الأصلي، أي أن الأمر يتعلق بمستتد

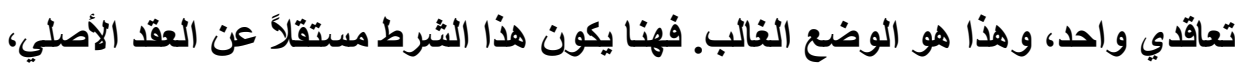
بحيث لا يتأثر بما يطرأ على هذا العقد من بطلان أو فسخ أو انقضاء من هيث هيث المبدأ

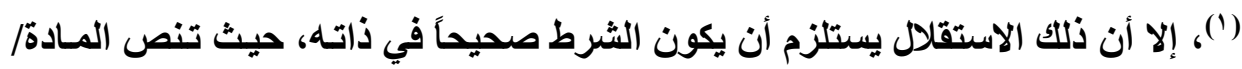

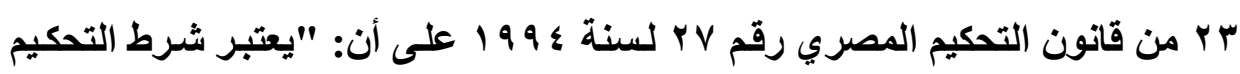
اتفاقًا مستقلاً عن شروط العقد الأخرى، ولا يترتب على بطلان العقد أو فسخه أو إنهائهـ أي أثر على شرط التحكيم الذي يتضمنه إذا كان هذا الشرط صحيحاً في ذاته". وقد يتفق أطراف العقد الأصلي صراحة على هذا الاستقلال. كأن يتفقوا في شرط

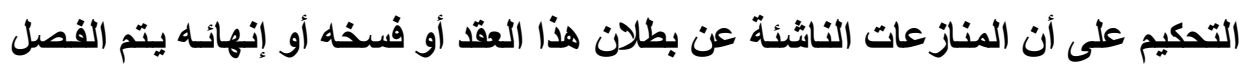

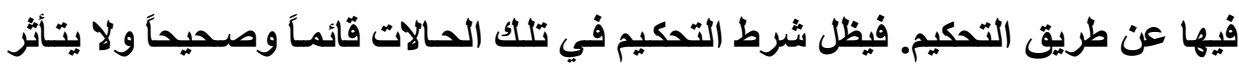
ببطلان العقد أو فسخه أو إنهائه. وقد لا يتفق الأطراف على ذلتك ولكن استقلال الشرط

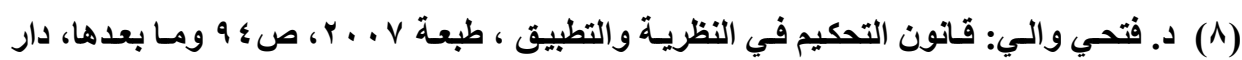

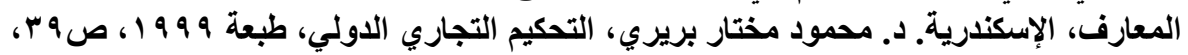

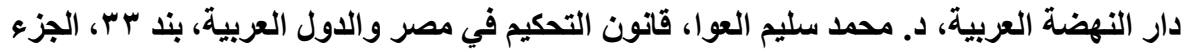

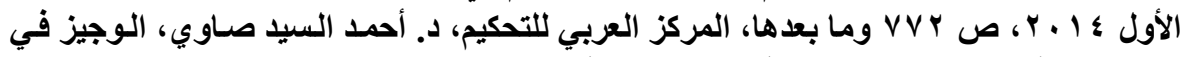

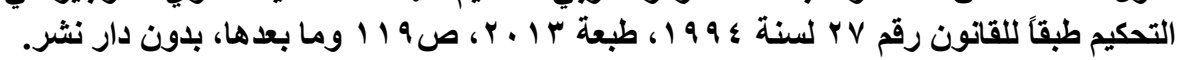

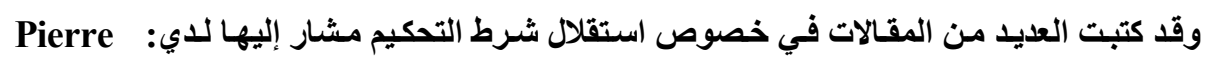
MAYER, art. Precit. 
عن العقد الأصلي يكون مفهوماً ضمنياً، ومستنداً على حكم المادة/ بr المشار إليها من قانون التحكيم المصري.

والحقيقة أن استقلال شرط التحكيم عن العقد الأصلي هو أمر طبيعي بمجرد اتفاق

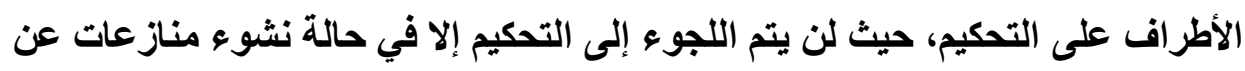

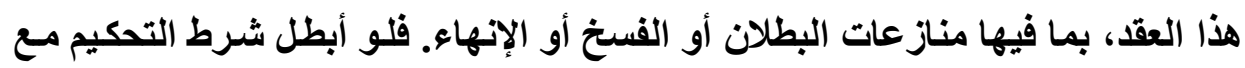

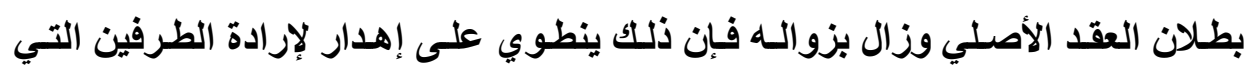
اتجهت، صراحة أو ضمنا، إلى التحكيم كوسيلة لفض المنازعات الناشئة عن العقد بـلاًا من القضاء.

ولكن استقلال شرط التحكيم عن العقد الأصلي يستلزم أن يكون هذا الشرط في

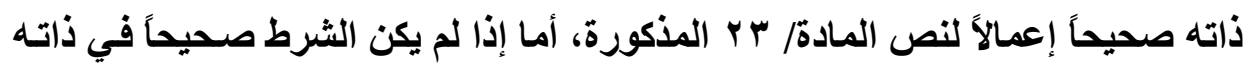
فيتبع العقد الأصلي ولا يستقل عنه ويرتبط مصيره بمصير هذا العقد ويزول بزواله. وتتمثل الحالات التي لا يكون فيها شرط التحكيم صحيحاً في ذاته، ويزول بزوال العقد الأصلي، فيما يأتي:

اـ إذا شاب إرادة المتعاقدين في العقد الأصلي أو أحدهما عيب من عيوب الرضا، أو نقص أو انعدام في الأهلية. فبإذا أبطل العقد الأصلي لأي من هذه الأسباب يبطل الأبل معه شرط التحكيم، لأن تلك الأسباب تتعلق بالإرادة في تكوين العقد، وتلك الإرادة واحدة في العقد الأصلي وشرط التحكيم الذي تتضمنه، فذات الإرادة المعيبة هي التي أبرمت العقد الأصلي وشرط التحكيم. r- إذا أبرم العقد الأصلي من قبل شخص بصفته وكيلاً عن أحد الطرفين دون أن يكون متمتعاً أصلاً بتلك الصفة أو تجاوز حدود الوكالة في إبرام هذا العقد. فانعدام الوكالة أو تجاوز حدودها، والتي كاتت سبباً في بطلان العقد الأصلي، تثمل أيضاً شرط التحكيم الواردة فيه. 
وننوه في هذا الخصوص إلى أن هناك حالة يكون فيها شرط التحكيم بـاطلاً أمسا

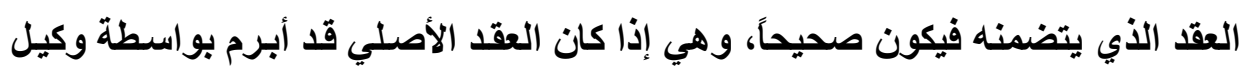

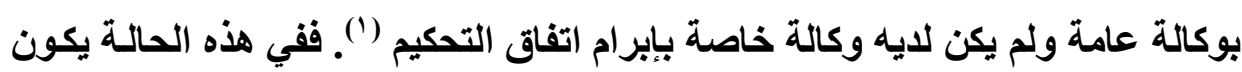

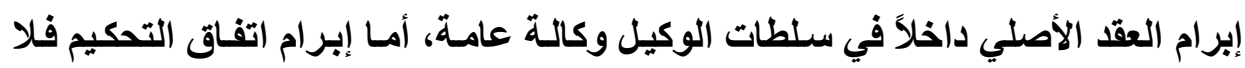

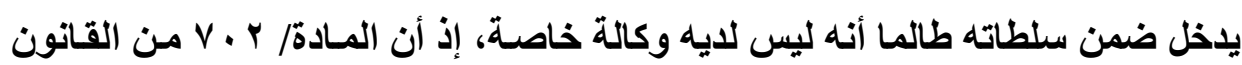
المدني المصري تستلزم وكالة خاصة لإبرام اتفاق التحكير.

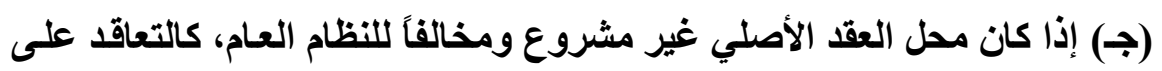
بيع صفقة مخدرات أو إيجار منزل للاعارة، فهنا يكون العقد الأصلي باطلاً بطلاناً مطلقاً

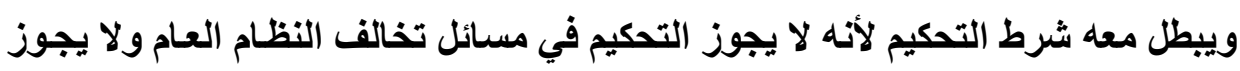

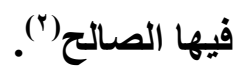

ثنانياً: انفصال شرط التحكيم: Separabilité

يكون اتفاق التحكيم منفصلاً عن العقد الأصلي إذا لم يرد كبند من بنوده، و إنما

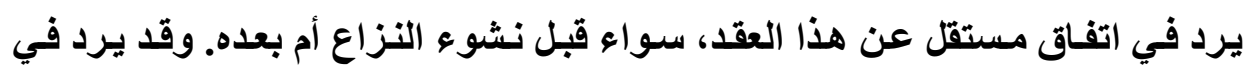

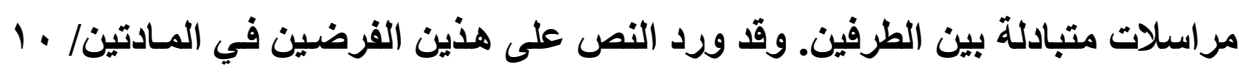

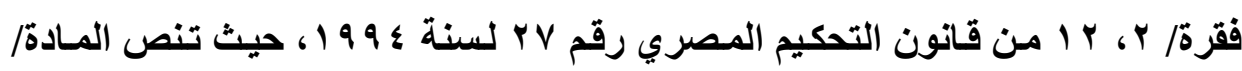

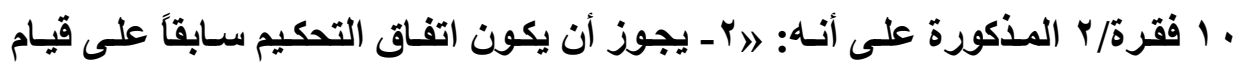

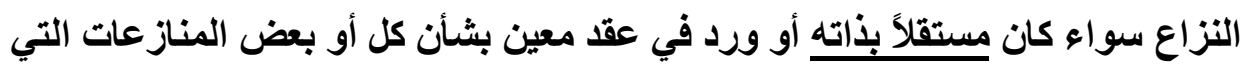

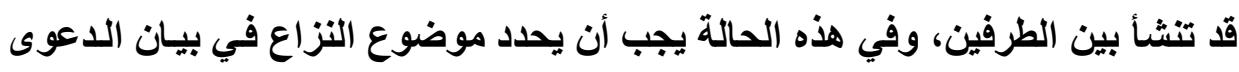

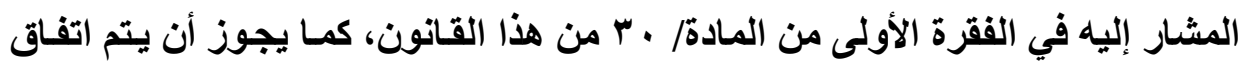

(1) Pierre MAYER, art. Prec. Spec. P. 365.

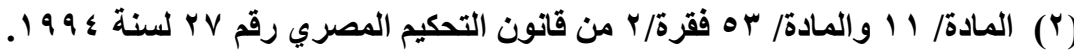


التحكيم بعد قيام النزاع ولو كانت قد أقيمت في شأنه دعوى أمام جهة قضائية. وفي هذه الحالة يجب أن يحدد الاتفاق المسائل التي يشملها التحكيم وإلا كان الاتفاق باطلاً).

$$
\text { وتتص المادة/ r ا من ذات القانون المذكور على أنه: }
$$

>ايجب أن يكون اتفـاق التحكيم مكتوبـاً وإلا كـان بـاطلًا. ويكون اتفـاق التحكيم

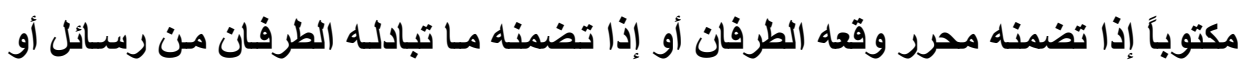

$$
\text { برقيات أو غيرها من وسائل الاتصال المكتوبةهان. }
$$

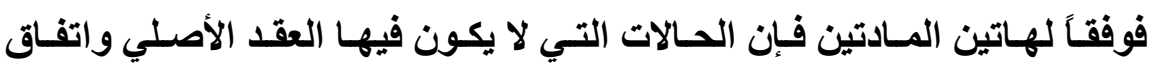
التحكيم وثيقة واحدة، ويأتي الاتفـاق المـكور في مستند منفصل عن العقد الأصلي،

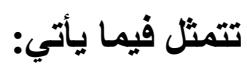

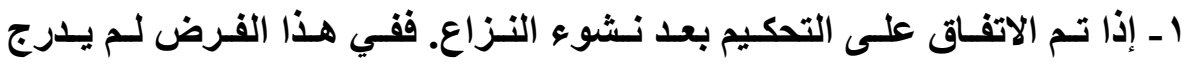

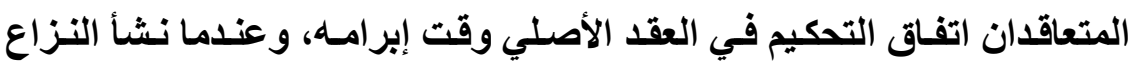
أبرما اتفاقًا مستقلاً اتفقاً فيه على التحكيم. ولكن في هذه الحالة يتعين أن يحدد الاتفاق المسائل التي يشملها التحكيم وإلا كان الاتفاق باطلاً. ץ ـ إذا أتقق على التحكيم قبل نشوء التزاع وورد هذا الاتفاق في مستتد مستقل عن العقد الأصلي. rا إذا لم يرد اتفاق التحكيم في وثيقة مكتوبة بالمعنى التقليدي، وإنما ورد في شكل

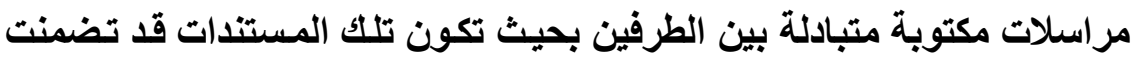
إيجاباً باتفاق التحكيم، صادفه قبول في مستتد مرسل ممن وجـه إليه الإيجـاب، فيبرم اتفاق التحكيم بموجب هذه المراسلات المتبادلة. 
ولكن في جميع الأحوال يتعين الربط وبشكل واضح بين الاتفاق المستقل والعقد

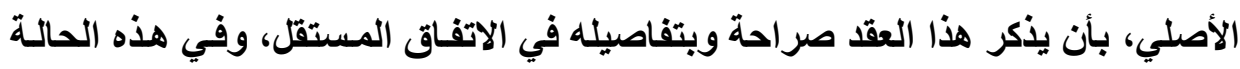
يعد الاتفاق المستقل من ملحقات العقد الأصلي Accessoire.

ووجه الاختلاف في شأن أثر زوال العقد الأصلي على اتفـق التحكيم بين الثرط

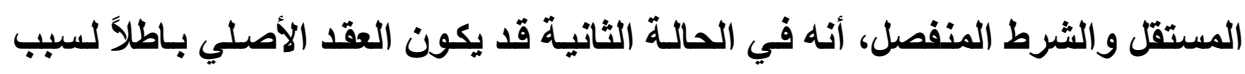

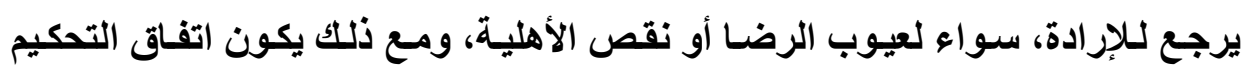

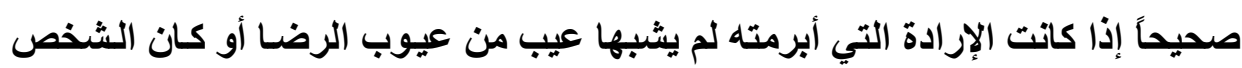

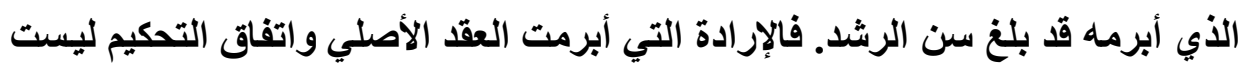

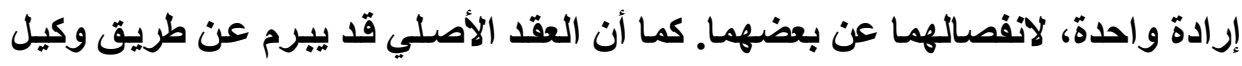

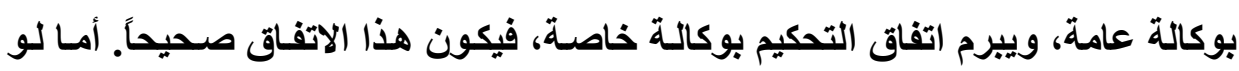

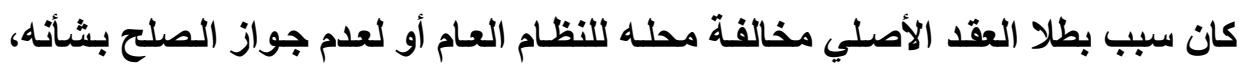

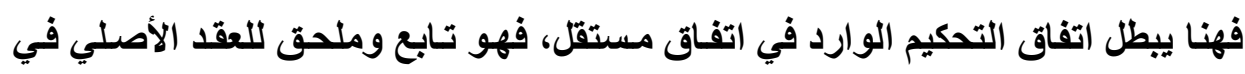

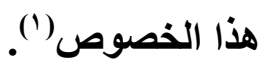

\section{الفرع الثاني}

\section{امتداد شرط التحكيم وانتقاله}

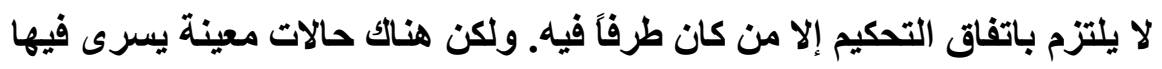

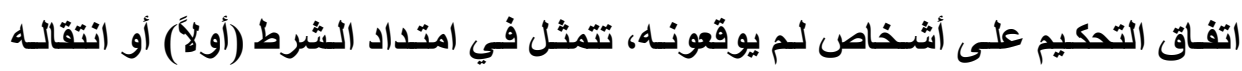

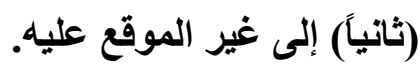

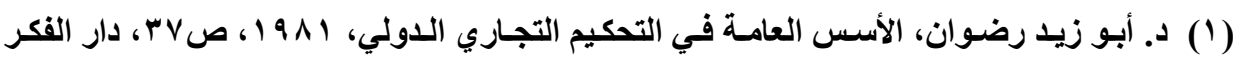

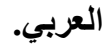




\section{L'extension de la clause compromissoire:}

يقصد بامتداد شرط التحكيم ضم أثخاص جدد إلى اتفـاق التحكيم لـ يكونـوا من

الأصل طرفاً فيه ولم يوقعوا عليه. وبامتداد شرط التحكيم إلى هؤلاء الأشخاص يضحون أطرافاً فيه ويحق لهم التمسك بـه

وبالتـالي يؤدي امتـداد شـرط التحكيم إلى توسيع دائسرة أشخاصسه، أي توسسيع النطاق الشخص لاتفاق التحكيم، حيث ينضم أشخاص جدد إلى هذا الاتفـق بجانب من

$$
\text { كانوا من الأصل أطرافًا فيه. }
$$

ودون الاخول في تفاصيل هذا الامتداد والنظريات التي قيلت بشأنه لتبريره لأن مجـال

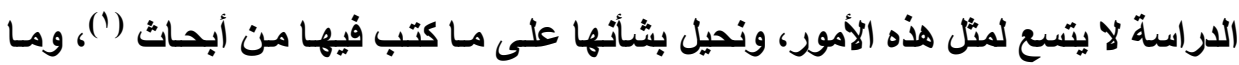

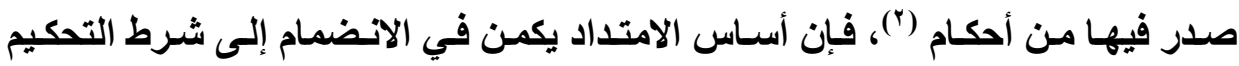
وقبوله ضمناً consentement tacite. ويشبت هذا الانضمام والقبول الضمني باتفـق التحكيم باشتراك الممتد إليه الاتفاق في إبرام العقد الأصلي أو تنفيذه أو إنهائه ("). وقد

(1) Eric Loquin, difference et convergence dans le regime de la transmission et de l'extension de la clause compromissoire, les cahiers de l'arbitrage, vol. 2, p. 49; - Ph. Delebecque, la transmission de la clause compromissoire, Rev. Arb. 1991. 196.

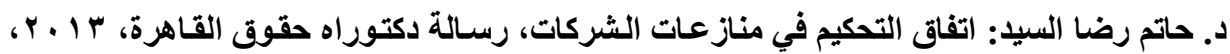

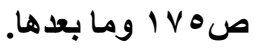

(2) Paris 22 mars 1995, Rev. arb. 1995, 247. obs. E. loquin; - Cass. Civ. 6 fevr. 2001, Rev. Arb. 2001. 1135, note, D. Cohen.

(r) د) د. حاتم رضا السيد، المرجع السابق، ص ع ـ r، وما بعدها. 
أصدرت محكمـة النقض الفرنسية العديد مـن الأحكام استتدت فيها إلى تلك المظـاهر الثلاثة للقبول الضمني بشرط التحكيم للقضاء بامتداده (')

ولكن يجب التنويـه على أن امتـداد شـرط التحكيم اسـتنـاداً إلى الانـضمام إليـه

والرضا الضمني به لا يطبق إلا إذا كانت القواعد الإجرائية التي تسري على الدعوى التحكيمية تستلزم كتابة شرط التحكيم للإثبات وليس للانعقاد. أما إذا كانت الكتابة لازمة الإنة

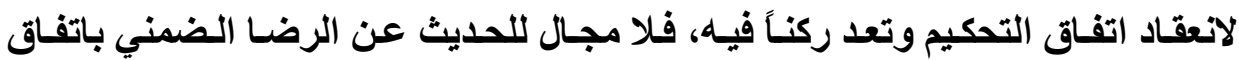
التحكيم، لأنه لا وجود لهذا الاتفاق بالنسبة لشخص لم يوقعه كتابة، مثنال ذلك قانون

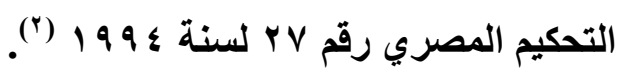
والجدير بالأكر أن من أكثر المجالات التي تثور فيها مسألة امتداد شرط التحكيم هو مجال العقود المرتبطة (")، وخصوصاً في مجال الشركات المرتبطة (") هيث دئ دائمساً ما يثور مد شرط التحكيم من الثركة الأم إلى الثركة الوليدة أو العكس.

ثانياً: انتقال شرط التحكيم: La transmission يقصد بانتقال شرط التحكيم خروج شخص من نطاقه ودخول آخر مكانـه. فاتتقال شرط التحكيم لا يغير من نطاقه الثخصي لا اتساعاً ولا ضيقاً، إذ يبقى أطراف اتفـاق مروح

(1) Cass. Civ. 27 mars 2007, D. 2007 Jun, 2077 note S. Bolle (láffaire ABS/ AGF.;

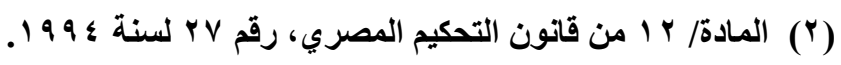

(3) D. Cohen. Arbitrage et groupe de contrat, Rev. arb. 1992, 271; -Ch. Seraglini, le transfert de la clause compromissoire dans les chaines de contrats, après l'arrêt peavey, les cahiers de l'arbitrage, vol.1., P. 87.

(4) Sentence arbitral, C. C. I du 23 sept. 1982, Rev. Arb. 1984. 137. 
التحكيم كما هم من حيث العدد، على عكس امتداد هذا الاتفـاق الذي يؤدي إلى توسبيع دائرة النطاق الثخصي له باتضمام أشخاص جدد إليه كما رأينا سابقًا ( '). ويجد انتقال شرط التحكيم أساسـه في كونـه أحد توابع الحق، حيث ينتقل الحق بتوابعه، وشرط التحكيم يقع ضمن تلك التوابع باعتباره وسيلة حمايـة الحق، وينتقل شرط التحكيم إلى الخلف ayant droit كانتقالـه إلى المشترى في عقد البيع، و إلى المظهر إليهه تظهيراً نـاقلاً للملكيـة في الأوراق التجاريـة، وإلى الكفيل الذي يحل محل

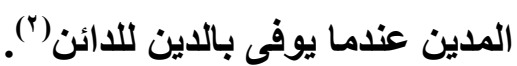
وعلى عكس امتداد شرط التحكيم، فِإن انتقالهه يـتم سواء كانت كتابته لمجرد الإثبات أم للانعقاد، لأن الانتقال يستتد إلى كون شرط التحكيم من توابع accessoire الحق المنقول، أما الامتداد فيستند إلى الرضا الضمني بشرط التحكيم. الامطاب الثاني

\section{انتقال وهد شرط التهكيم}

\section{في هبال العلاقات التجارية المرتبطة}

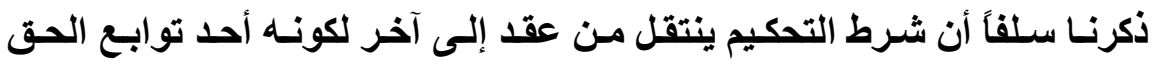
المنقول لأنه وسيلة حمايته. أما امتداد شرط التحكيم من علاقة عقدية إلى أخرى يستند إلى الانضمام لتلك العلاقة الأخرى والرضا الضمني باتفاق التحكيم.

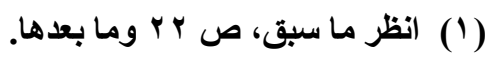

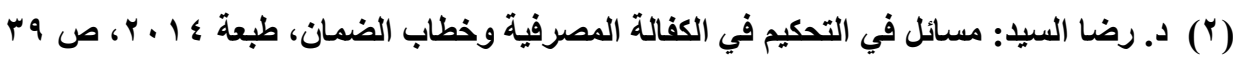
وما بعدها، دار النهضة العربية. 
ولو طبقتا الاتتقال والامتداد في مجال العلاقات التجاريـة الثلاث المرتبطة، والتي سندرسـها لاحقاً، وهي الأوراق التجاريـة، والشركات، والعمليـات المصرفية، سيتضح الآتي:

(أولاً): فيما يتعلق بمد شرط التحكيم أو انتقاله في مجـال الأوراق التجاريـة، فبإذا ورد هذا الثرط ضمن بنود عقد الأساس فإنه يلزم طرفيه حتى بعد نشوء الورقة فئة، وهمـا الساحب والمستفيد، دون الحديث عن مد أو انتقال لله. فتحرير الورقة التجاريـة إعمالاً للبند الوارد في علاقة الأساس ليس تجديداً للالتزام الناشئ عن تلكك العلاقة وإنما مجرد تغيير في الأداة التي تثبت الدين، فتصبح تلك الأداة هي الصك بعد أن كان العقد، كمـا سنرى لاحقًا (') ولكن هذا الثرط يمتد إلى المسحوب عليه الذي لم يكن طرفاً في علاقة

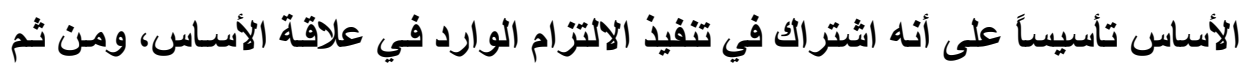

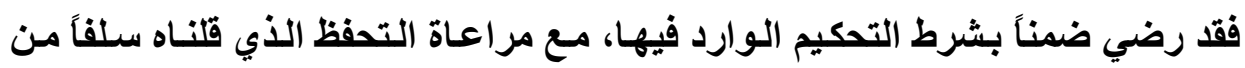
حيث كون الكتابة شرطاً لانعقاد اتفاق التحكيم أم مجرد وسيلة لإثباته. (ثثانياً): أمسا في العلاقات الأخرى التي تنشأ عن التعامل بالورقة التجاريـة عن طريق تظهيرها، أي العلاقات التي تنشأ بين المظهرين المتعاقبين على الورقة، فإذا كان

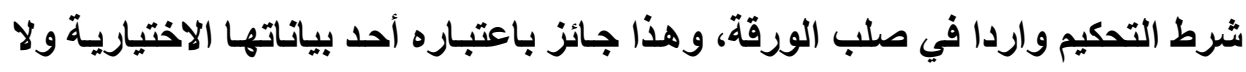

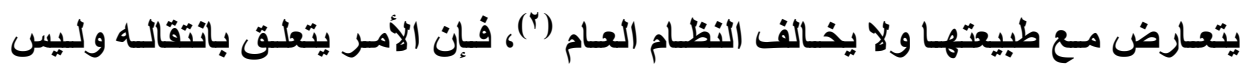
بامتداد. ويتم انتقاله بالتظهير الناقل للملكية إذ أن المظهر إليه يعتبر خلفاً للمظهر. أمسا إذا كان هذا الشرط مدرجاً في عقد الأسـاس فإنها يمتـد للمتعاملين بالورقة باعتبـار أنهم اشتركوا في تتفيذ الالتزام الصرفي فرضوا ضمناً بشرط التحكيم. 
(ثالثًاً): وبالنسبة لمـ شرط التحكيم وانتقالـه في مجال العلاقـات بين الشركات المرتبطة، كالشركة الأم والشركة الوليدة، أو الشركة القابضة والشركة التابعة، فإنـه يمتد من العقد الأي تبرمه أي من تلك الثركات إلى الثركة الأخرى بحسبان أن الأخيرة

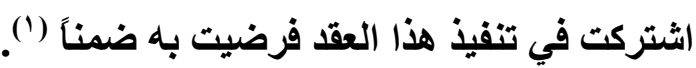
أمسا عن انتقال الشرط من شركة إلى أخرى فيحدث في حالة الاتدماج، سواء بالضم أو بالمزج، حيث ينتقل هذا الشرط من الشركة المندمجة إلى الشركة الدامجة باعتبار أن الأخيرة خلفاً للأولى. ولا يحاج هنا بعدم الانتقال استناداً إلى أن شرط التحكيم

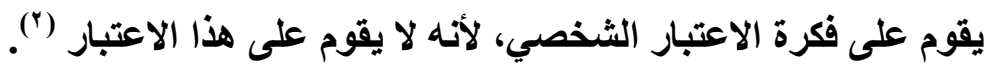
r- وعن مـد شرط التحكيم أو انتقاله في مجـال العمليـات المصرفية: الاعتمـاد

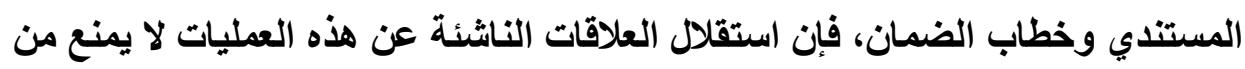
مد شرط التحكيم من علاقة إلى أخرى على أساس اشتراك الممتد إليه الشرط في تنفيذ

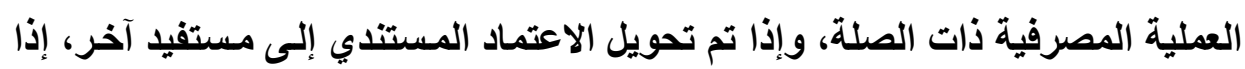
ما اتفق على قابلية الاعتماد للتحويل، فإن شرط التحكيم ينتقل إلى المستفيد المحول إليه باعتباره خلفاً للمستفيد الأول.

(1) D. Cohen. L'arbitrage et société, op. cit. p. 376.

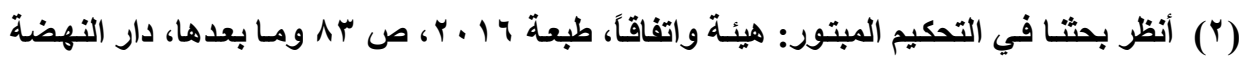
العربية. 


\section{الفصل الأول}

\section{الاستقلال بين العلاقات العقدية في هبال \\ الأوراق التجارية}

تتعدد وتتشابك العلاقات التي تصاحب نشأة الالتزام الأصلي، والذي يؤدي بعد ذلك إلى نشوء الالتزام الصرفي بموجب الورقة التجارية. وكذلك تتعدد العلاقات التي تنولدابلد

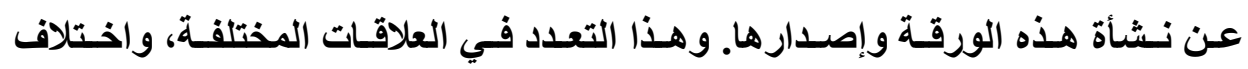
أشخاصها وموضوعها وسببها، قد آثار جدلاً واسـعاً ولا يزال حول الأسـاس القانوني لكل علاقة من تلك العلاقـات. ولكن إذا كـان هذا الجدل أقل وطـأة عندما يتعلق الأمر

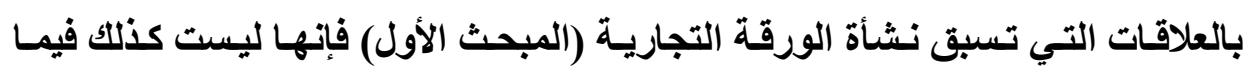
يخص العلاقات المتفرعة عن الالتزام الصرفي الذي أنشأته الورقة التجاريـة (المبحث

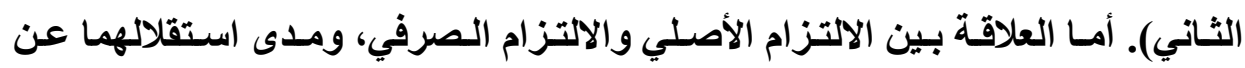
بعضهما، ومدى تأثير كل منهما في الآخر، فكاتـت الشغل الشاغل لآراء الفقه وأحكام القضاء في مجال الأوراق التجارية (المبحث الثالث).

\section{المبحث الأول}

\section{الأساس القانوذي للعلاقات السابقة على نشأة}

\section{الورقة التجارية والاستقلال بينها}

لا تنشأ الورقة التجاريـة بالعلاقـات التـي تشملها مـن فراغ، وإنمـا هـي ترجمـة

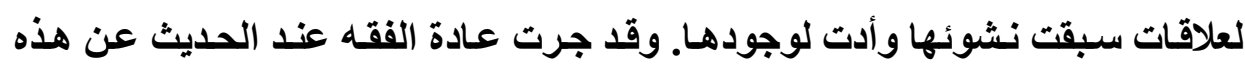

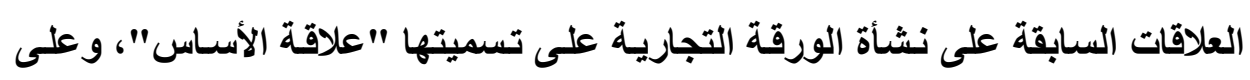
تسمية الالتزام الناشئ عنها بالالتزام الأصلي. 
فتنشأ علاقة الأساس، بمفردات العلاقات المختلفة التي تكونها خارج نطاق قانون الصرف، فـلا تتـأثر بقواعده ولا يـتم تفسير أسـاسـها القـانوني في ضـوء أحكـام هـا القانون. فالبيئة التي نبتت فيها علاقة الأسـاس تختلف جذرياً عن تلك التي نشأ فيها الالتزام الصرفي. ولذلك فإن البحث عن الأسـاس القانوني لعلاقة الأسـاس، بمفرداتها

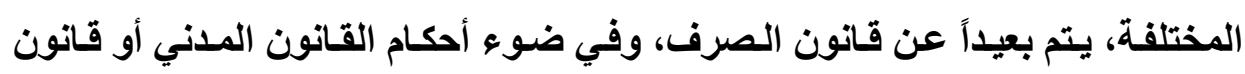

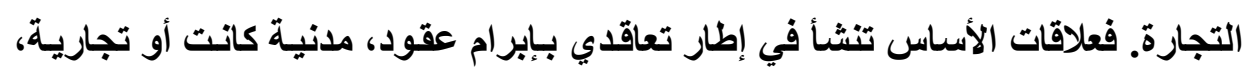
بين مجموعة من الأشخاص، لتحقيق غرض محدد من العقد. فيبرم عقد بين شخصين

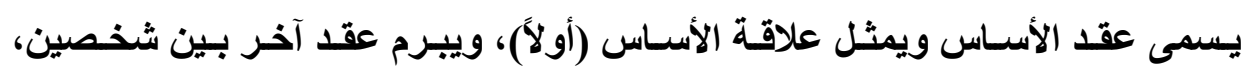

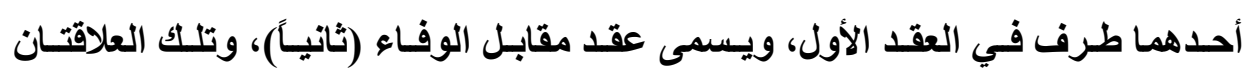
مستقلتان عن بعضهما البعض (ثالثاً). أولاً: الأسساس القانوني لعقد الأساس:

تبدأ دورة الورقة التجارية بعقد يبرم بين شخصين أحدهما دائن والآخر مدين، ويختلف نوع هذا العقد باختلاف سبب المديونيـة. إذ في الغالب مـا تمثل تلك المديونية

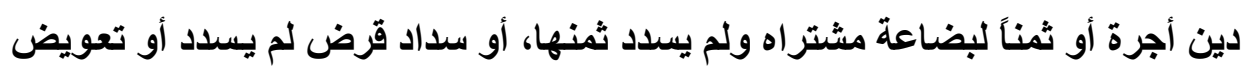
لم يتم دفعه، فيبرم عقد بين المؤجر والمستأجر يتكون من عدة بنود من بينها بند لسداد قيمة الأجرة، ويبرم عقد بين البائع والمشتري يتكون أيضا من مجموعة بنود من بينها

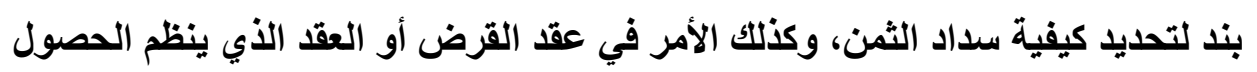
على تعويض أصاب أحد الطرفين(').

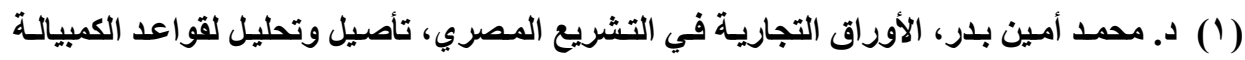

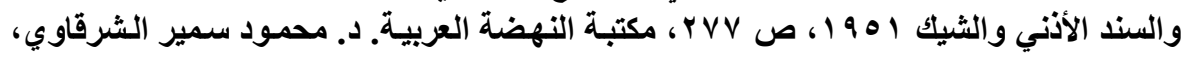

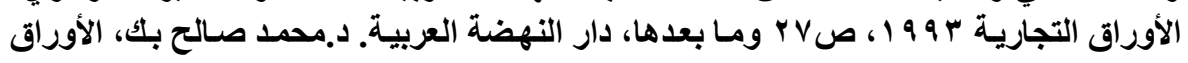

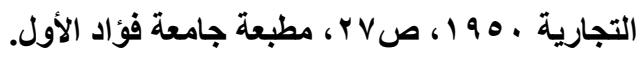
$=$ 
ولا حديث من علاقة هذا العقد كعقد أساس للورقة التجارية إلا إذا تضمنت بنوده

بنداً يقضي بأن تسوية المديونية الناشئة عنه تكون بقيام المدين بتحرير ورقة تجارية التهاية

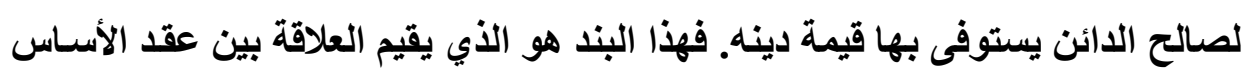
والورقة التجارية. لأنه نفاذاً لهذا البند يصدر المدين ورقة تجارية لصالح الدائن ويكون

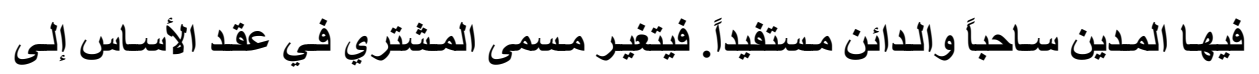

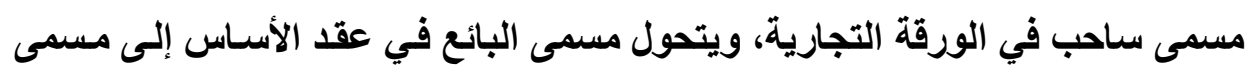

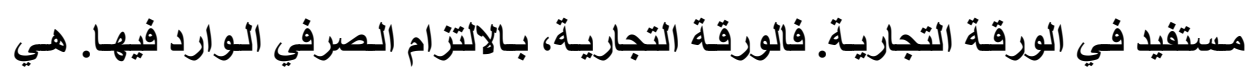
ترجمة لبند كيفية الوفاء بالثمن.

فعلاقة الأسساس المذكورة التي سبقت نشأة الورقة التجاريـة، والتي انتقلت في ثوبها الجديد إلى الورقة، ليست ناشئة عن الورقة وإنما كاتت قائمة قبل نشوء الأخيرة. وعند الحديث عن الأساس القانوني لتلك العلاقة فإنه يتعين بيان هذا الأساس في

الفترة السابقة على نشأة الورقة التجارية، أي بعيداً عن أحكام قانون الصرف. أمسا إذا

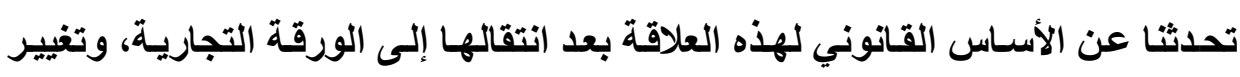
مسمى أطر افها واختلاف موضوعها وسببه عن موضوع وسبب علاقة الأسساس خـارج

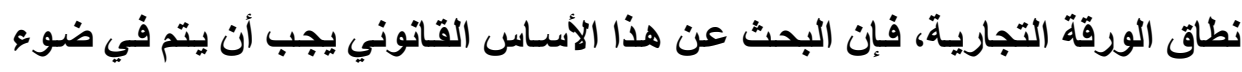
قواعد قانون الصرف وليس في ضوء القواعد العامـة في القانون المدني أو قانون

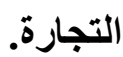

ولا نـرى ثـــة احتمـال لإثـارة الجـدل أو الخـلاف حـول الأسـاس القـانوني لعلاقـة

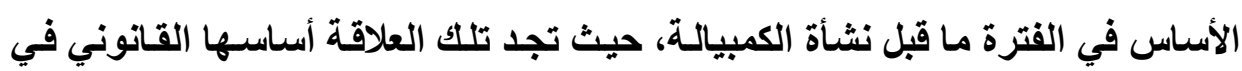

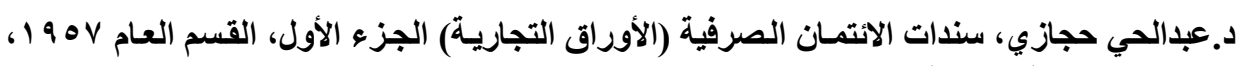
ص IV ا المطبعة العالمية. 
العقد المبرم بين الدائن والمدين، أياً كان مسماه، باعتبار أن العقد هو قانون العاقدين.

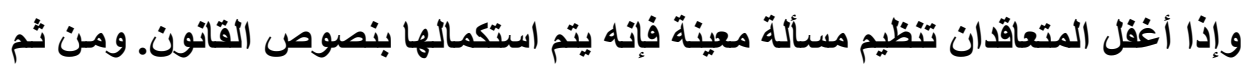
فِان الأساس القانوني لهذه العلاقة هو العقد والقانون.

وتجدر الإشارة إلى أن هناك فرضاً، وإن كان نادر الحدوث، إلا أنه متصور، وهو عدم وجود علاقة سابقة بين المتعاملين بالورقة التجارية. فقد تنشأ العلاقة بينهم لأول

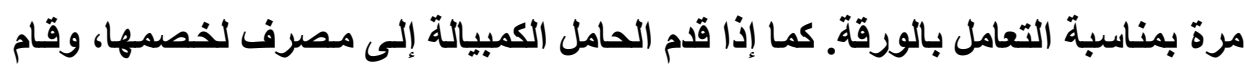
المصرف بعملية الخصم نظير تقليم الورقة إليه، فإن المصرف هنا يكون حاملاً للورقة، بمالة

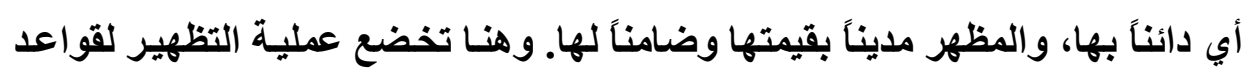
قانون الصرف، ويتم البحث عن الأساس القانوني لها بمنأى عن رابطة قانونية سـابقة وفئة بين البنك الخاصم كمظهر إليه والثخص طالب الخصم كمظهر (') ثانياً: عقد مقابل الوفاء:

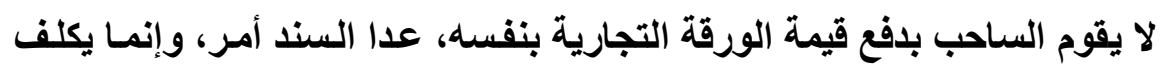

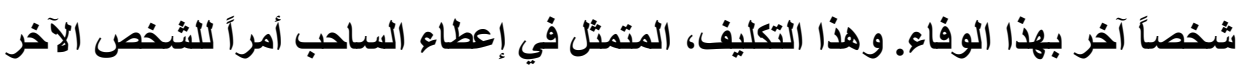

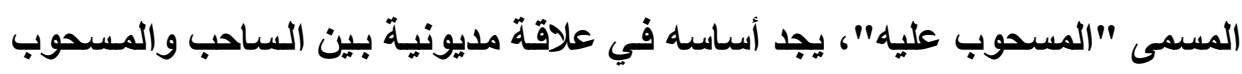
عليه، نشأت خارج نطاق الورقة التجاريـة، وفي وقت سـابق على إصدار هذه الورقة. فالعلاقة بين الساحب والمسحوب عليه لم تنشئها الورقة التجارية.

وتلكك العلاقة التي يكون فيها الساحب دائناً والمسحوب عليه مديناً تنشأ نتيجة عقد، أياً كان نوعه، يرتب للساحب ديناً في ذمـة المسحوب عليه. وعندما يعطي الأول 
للثاني أمراً بالوفاء بقيمة الورقة فإن هذا الوفاء يتم من الدين الذي للساحب في ذمـة المسحوب عليه. ولذلك تسمى تلك العلاقة بعلاقة مقابل الوفاء.

و وعلى ذلك فإن الأساس القانوني لعلاقة مقابل الوفاء، قبل أن تنتقل إلى الكمبيالة ويتغير مسمى أطر افها إلى ساحب ومسحوب عليه، يتمثل في العقد المبرم بين الدائن

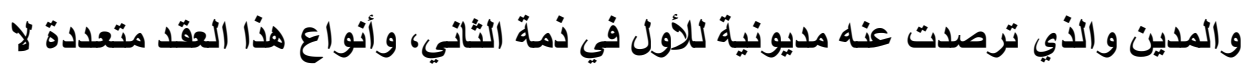

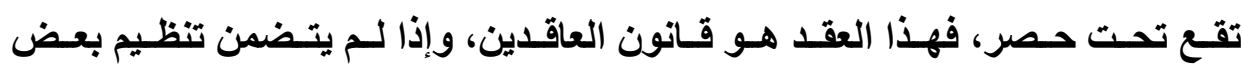

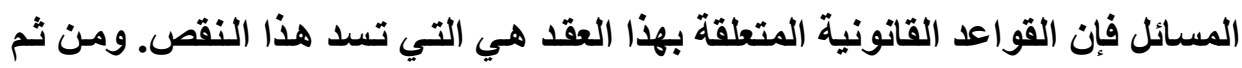

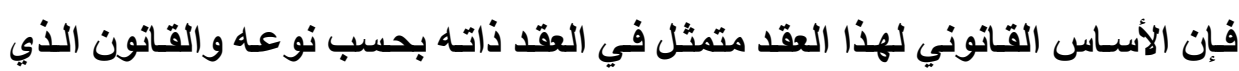

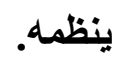
ثالثاً: استقلال عقد الأساس من علاقة مقابل الوفاء: إن علاقة الأسـاس التي تضم طرفي عقد الأسـاس، اللذان يصبحان فيمـا بعد

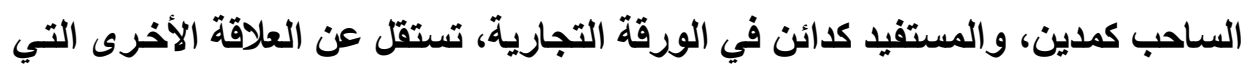

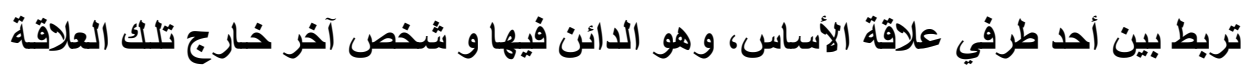

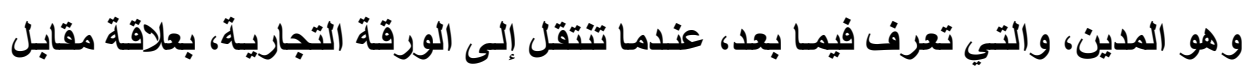

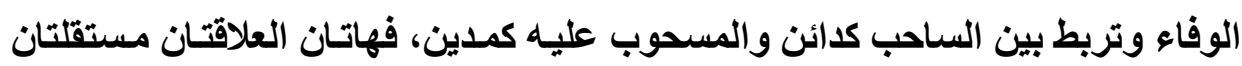
عن بعضهما البعض ولا أثر لأي منهمـا على الأخرى بـالرغم من أن أحد أثخاصهما

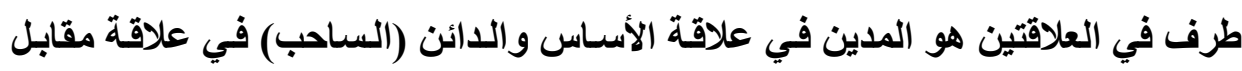

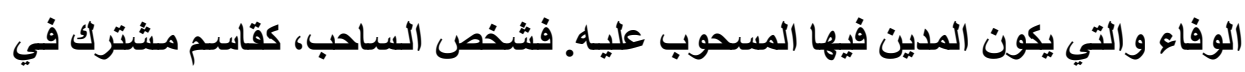

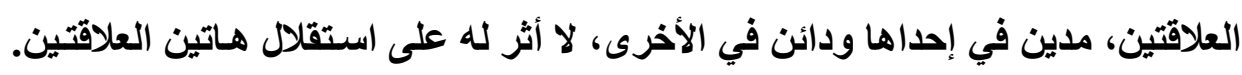

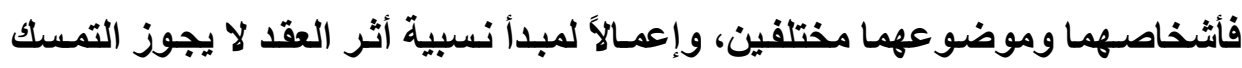
بأية دفوع ناشئة عن إحداهما في العلاقة الأخرى. 


\section{المبحث الثاني \\ الأساس القانوذي للعلاقات التي تتضمنها \\ الورقة التجارية والاستقلال بينهـها}

هناتك عدة علاقات تتضمنها الورقة التجارية، منها ما كان قائماً قبل نشأة الورقة

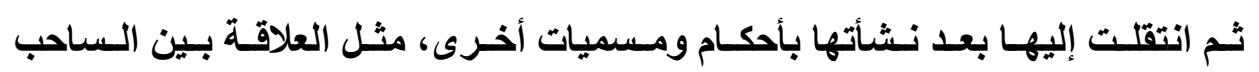

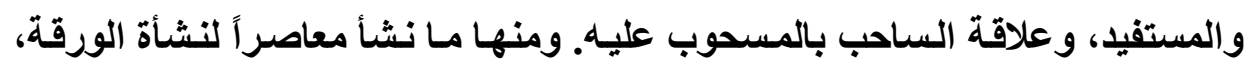
حيث لم تكن قائمة من قبل، وإنما الورقة التجارية هي التي أوجدتها، مثل العلاقة بين المسحوب عليه والمستفيد الأول والحملة المتعاقبين نتيجة تظهير الورقة، والعلاقة بين المظهر والمظهر إليه، والعلاقة بين الساحب والحامل غير المستفيد الأول. وقد أثير

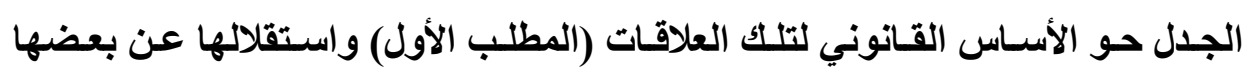
البعض (المطلب الثاني).

\section{المبب الأول}

\section{الأساس القانوني للعلاقات التي تتضمنها}

الورقة التجارية

لقد قيلت العديد من النظريات، سواء من جانب الفقه الفرنسي (الفرع الأول)، أو

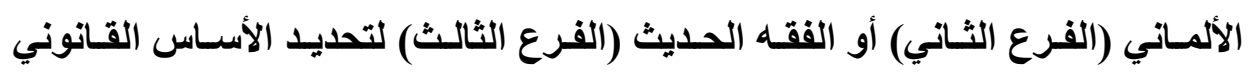
للعلاقات التي تتضمنها الورقة التجارية. 


\section{الفرع الأول}

\section{النظريات الفقهية التقليدية في الأساس القانوني للعلاقات}

\section{التي تتضمنها الورقة التجارية}

نعرض لتلـك النظريـات في الفقـه الفرنسي (أولاً) وفـي الفقـه الألمساني (ثانيـاً)

التقليدي.

$$
\text { أولاً: الفقه الفرنسي التقليدي: }
$$

ذهب الفقه التقليدي الفرنسي إلى أن الورقة التجارية مجرد أداة لإثبات التزام

سابق على نثأتها ولا ترتب التزاماً جديداً على عاتق من وقعها. وقد إقترح هذا الفقه الفته

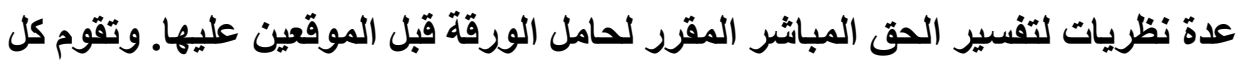

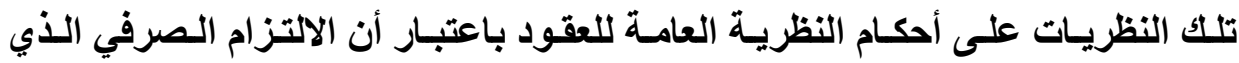

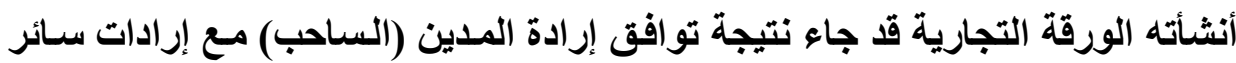
الموقعين على الورقة للوفاء بقيمتها' (') .

وقد انقسم هذا الفقه إلى ثلاثة اتجاهات لتحديد نوع العقد الذي يتولد عن الالتزام

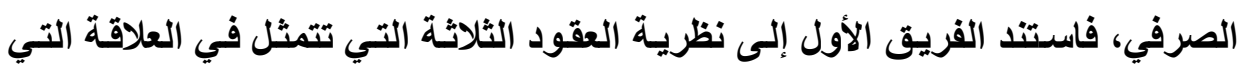
تربط الساحب بالمستفيد وهي عقد الأساس الذي تحول بنثأة الورقة إلى عقد الصرف،

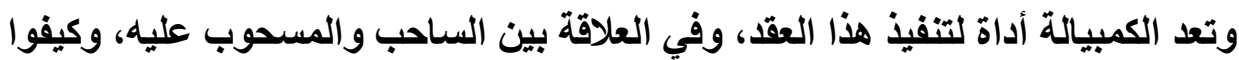

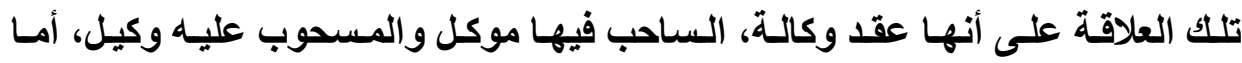

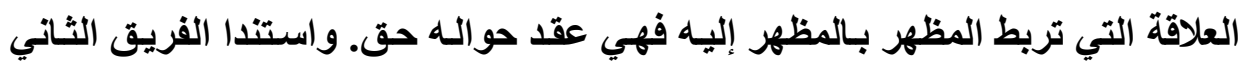


على نظرية الإنابة في الوفـاء والكفالة والفريق الثالث قـال بنظريـة الاثتراط لمصلحة

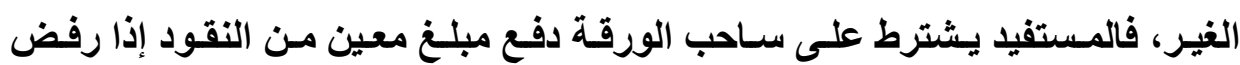

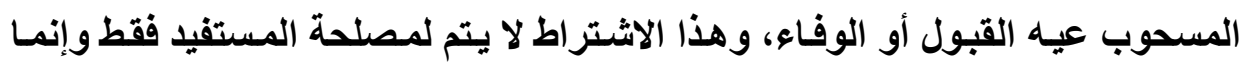

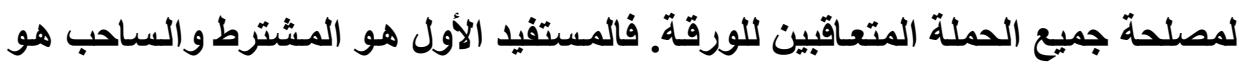
المتعه وحامل الورقة هو المنتفع.

إلا أن كل تلك النظريـات قد تعرضت لانتقـادات كثيرة دارت معظمها حول عدم كفاية تلك النظريات لتقديم التحليل الوافي للعلاقات الناشئة عن الورقة، وعدم ملائمتها في بعض الأحيان لأحكام الالتزام الصرفي. ونحيل بشأن تلك الاتتقـادات على مـا عرضـه

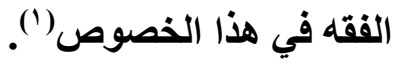
ثانياً: الفقه الألماني التقليدي: على عكس مـا ذهبت إليـه النظريـات الفرنسية، تقوم النظريـات الألماتيـة على النى أساس أن التوقيع على الورقة التجارية ينشئ في ذمـة الموقع التزامـاً مستقلاً ومتميزاً

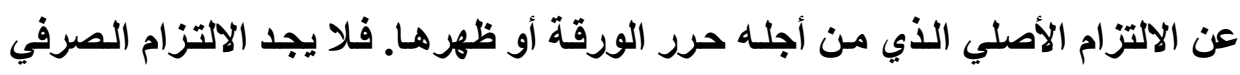

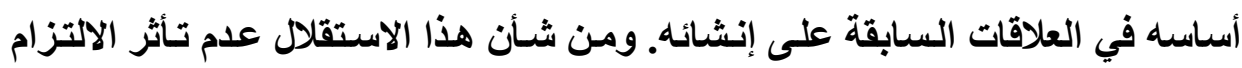
الصرفي بانتفاء أو بطلان أو انقضاء أو فسخ الالتزام الأصلي.

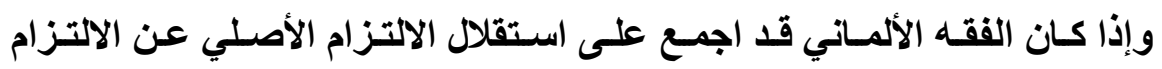
الصرفي، إلا أنه قد اختلف في بيان الأساس القانوني للالتزام الصرفي وسند استقلاله عن الالتزام الأصلي. وقد قيل في هذا الخصوص ثُلاث نظريات هي: 
ومبنـى هذه النظريـة أن كافة المـوقعين على الورقة يرتبطون فيمـا بينهم بعقد

يلتزمون بموجبه بدفع قيمة الورقة في ميعاد استحقاقها. وهذا العقد الذي يترتب عليه الالتزام الصرفي هو عقد مستقل عن العلاقات السابقة على إنثاء الورقة، ولاتئه تعد هذه

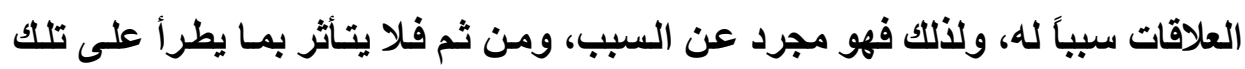
العلاقات السابقة من بطلان أو انقضاء أو فست. فإذا وقع المسحوب عليه مثنلاً بـالقبول فإنـه يلتزم بالوفـاء قبـل حامـل الورقة ولـو لـم يكن قد حصل مـن الساحب على مقابـل الوفاء، وكذلك لا أهمية لذكر سبب الورقة المتمثل في بيـان وصول القيمة. فكل من فئن

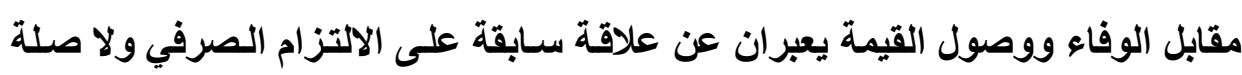
لـها بهذا الالتزام (').

إلا أن هذه النظرية قد تعرضت لاتتقادات كثيرة من أهمها أنها تتنـاقض مـع أحكام

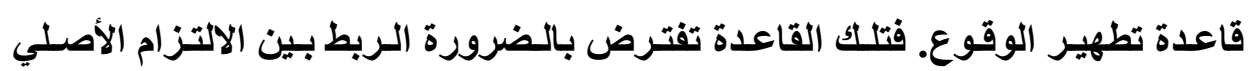

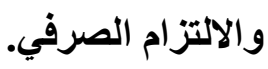

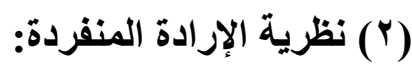
لقد شبه أنصار هذه النظرية الورقة التجارية بالنقود باعتبارهـا عملة التجار في

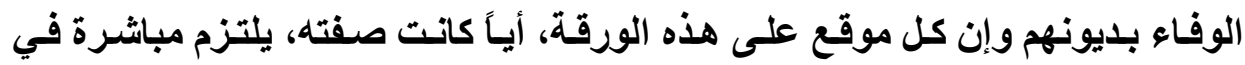
مواجهة حاملها بإرادته المنفردة بدفع قيمتها في ميعاد استحقاقها. فالموقع على الورقة

(1) حول تلك النظرية بصفة عامة انظر:

- G. FRIEDEL, de l'inopposabilité des exceptions en matiere d'effets de commerce, Paris 1950; - F. A zencot, la protection de porteurs d'obligations. L. G. D. J. Paris 1939. 
يصبح مديناً قبل أن يعرف من هو دائنه، وهذا يعد بمثابة وعداً بالوفاع صادر عن إرادة منفردة، وهو بذلك يعتبر نوعاً من الالتزام المجرد.

إلا أن تلك النظرية قد لاقت انتقادات عديدة أهمها عدم دقة تشبيه الورقة التجارية

بالنقود للاختلاف الجوهري بينهما. (r) نظرية اتحاد الإرادة المنفردة والعقد:

وقد حاول أنصار هذه النظريـة تفـادي الانتقـادات التي وجهت إلى نظريتي العقد

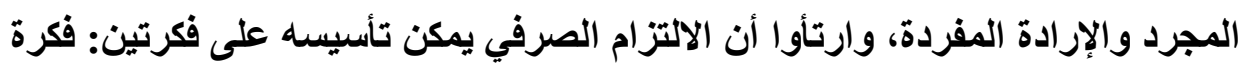
العقد في العلاقة بين المدين ودائنه المباشر كالعلاقة بين الساحب وبين المستفيد الأول والعلاقة بين المظهر والمظهر إليه المباشر، وفكرة الإرادة المنفردة في العلاقة بين أي موقع على الكمبيالة، وأي حامل لها، ممن لا تربطه به صلة مباشرة (') إلا أن هذه النظريـة تعرضـت لأوجـه النقد التـي وجهت لنظريتـي العقد المجرد والإرادة المنفردة.

\section{الفرع الثاني}

\section{النظريات الحديثة}

لقد هجرت النظريات الحديثة في مجال تحديد الأساس القانوني للالتزام الصرفي بما يتفرع عنه من علاقات مختلفة توجد داخل الورقة التجارية، إسناد هذا الالتزام إلى مئ الإرادة المتمثلة إما في العقد أو الإرادة المنفردة.

(1) د. محمد أمين بدر، المرجع السابق، فقرة ب به ، د. محمود سمير الثرقاوي، الأوراق التجارية، المرجع السابق، صس ــ. 
وربطت تلك النظريات الحديثة بين أسناس الالتزام الصرفي والقاعدة التي تسود أحكام قانون الصرف وتعد عموده الفقري وهي قاعدة تطهير الوقوع، حيث رأي أنصار

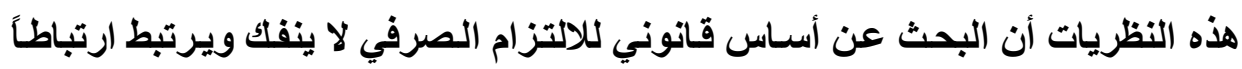

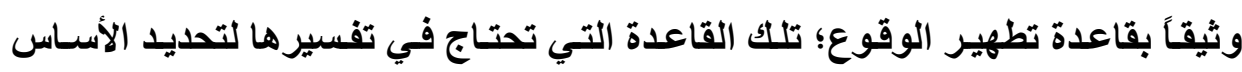
القانوني الصحيح للالتزام الصرفي.

فذهب أنصار هذه النظريات الحديثة إلى أن القانون هو الذي قرر حرمـان المدين

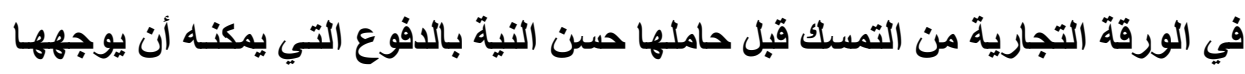

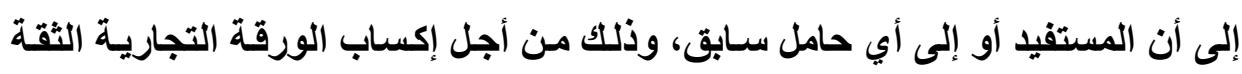

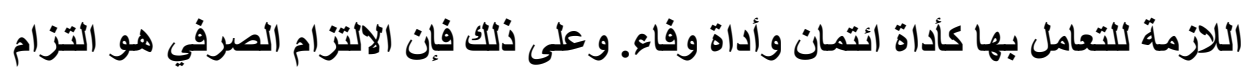

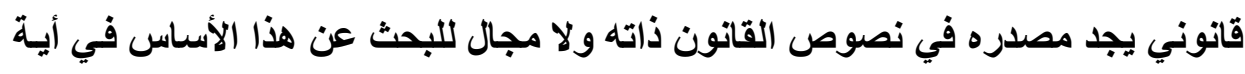
علاقة تعاقدية أياً كان نوعها أو أشخاصها أو موضوهو فهرها. ورغم اتفاق أصحاب النظريات الحديثة في أن مصدر الالتزام الصرفي وأساسـه هو القانون، إلا أنهم قد اختلفوا فيما بينهم في هذا الخصوص، وذلتك على النحو التالي: أولاً: نظرية الظاهر وحسن النية: ذهب أنصار هذه النظرية إلى أن تداول الورقة التجارية تظلبت وطغت على جميع

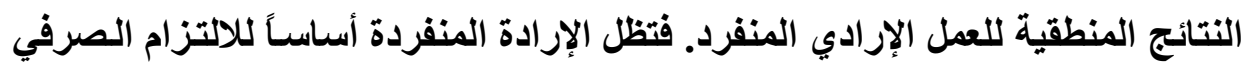
خلال مدة بقاء الورقة في مرحلة سكون، أما إذا تحركت عن طريق التداول ووضعت في الإدة في الاردي

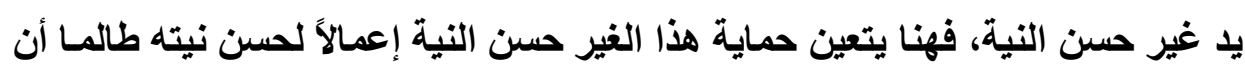
الورقة صحيحة في مظهرها العام الخارجي ولا تنظوي على عيب ظاهري. فالغير حسن

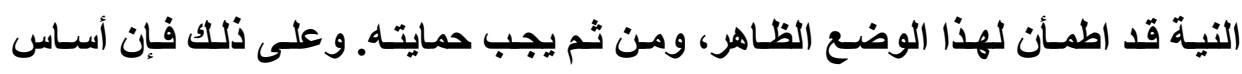

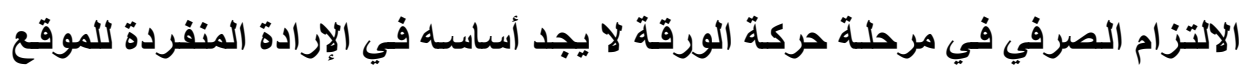


عليها وإنما في القانون الذي قرر حماية الغير حسن النية بإعطائه حق التمسك بقاعدة تظهير الدفوع وبمنع المدين من التمسك بالدفوع العالقة بالورقة. ثانياً: نظرية المسئولية المدنية(')

مؤدي هذه النظريـة أن الموقع على الورقة التجاريـة يلتزم في مواجهة حاملها بسداد قيمتها، ولا يجوز لله أن يخل بهذا الالتزام، ويكون من شـأن إخلالهه بهذا الالتزام قيام مسئوليته المدنية بتعويض الحامل حسن النية عما أصابه من أضرار. إلا أن أنصار تلكك النظريـة قد اختلفوا في نوع هذه المسئولية من حيث الخطأ الواجب توافره لقيامها. فذهب فريق إلى أن إخلال الموقع على الورقة بدفع قيمتها يعد في ذاتـه خطأ لأنها.

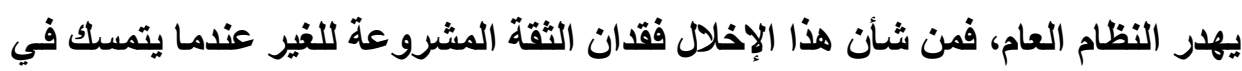
مواجهة الحامل حسن النية بأية دفوع قد تشوب التزامسه كسبب من أسـابب البطلان أو الفسخ، وفقدان الثقة في الورقة يعد اعتداء على النظام العـام. والتزام الموقع بسداد قيمة الورقة يفرضه القانون نتيجة واقعة محددة هي واقعة التوقيع على الورقة. وذهب فريق آخر إلى أن المسئولية في هذه الحالة لا تقوم على الخطأ المفترض أو واجب الإثبات، وإنما تقوم على فكرة تحمل التبعة. فالورقة التجاريـة لا تعد تجديداً للالتزام الواقع على عاتق الموقع ولكنها وسيلة لإثبات العلاقة السابقة عليها، ويتحمل الموقع تبعة وجود تلك العلاقة لأن الغير اطمـأن على ذلك نتيجة هذا التوقيع ونشوء الوضع الظاهر الأي خلقه.

(1) Valery, quell est le fondement de l'obligation engendrée par l'acceptation d'une lettre de change, Ann. De dr. Com. 1923p. 180 etss.

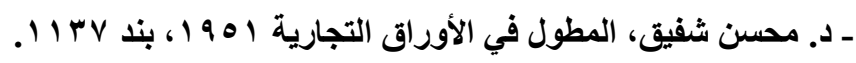




\section{ثالثاً: نظرية الإرادة والقانون('):}

ذهب أنصار هذه النظريـة إلى أن الالتزام الصرفي ينشأ نتيجة إتحاد مصدرين:

إرادة الموقع على الورقة، والقانون. فيجد الالتزام الصرفي مصدره في إرادة طرفيه الصها

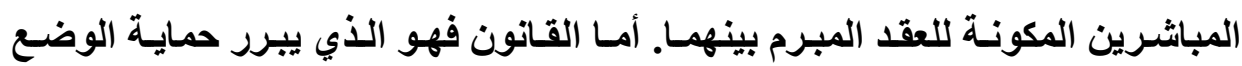
الظاهر لمصلحة الحامل الشرعي حسن التيـة للورقة التجاريـة. ومن ثم ينشأ، وبحكم القانون، في ذمة كل موقع التزام مباشر في مواجهة الحامل حسن النيـة الذي يثق في صحة الصك الظاهرة.

\section{الإطلب الثاني \\ الاستقلال بين العلاتات التبي تتضمنهها الورقة التجارية \\ والتوقيدات الهاردة عليهها}

تستقل العلاقات التي تشتمل عليها الورقة التجارية عن بعضها البعض (الفرع

الأول)، ومـن الأسباب الرئيسية لهذا الاستقلال هو استقلال توقيعـات الموقعين على لهـ الورقة (الفرع الثاني).

\section{الفرع الأول}

\section{الاستقلال بين العلاقات التي تقضهنهـا}

\section{الورقة التجارية}

ذكرنــا أن الورقـة التجاريـة تـشتمل على مجموعـة مـن العلاقـات، مــع بعض

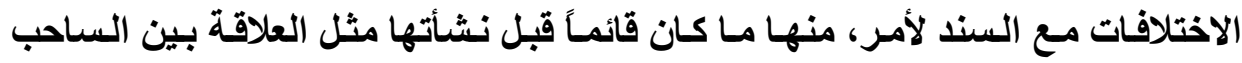
والمستفيد، والعلاقة بين الساحب والمسحوب عليه، ومنها ما أوجدته الورقة بتداولها،

(1) Lecico et Roblot, troité de droit commercial no. 116. 
مثل العلاقـة بـين المسحوب عليـه والمستقيد والعلاقـة بـين الملتزمين بالوفـاء بقيمـة الورقة والحملة المتعاقبين لها الذين لا تربطهم بالملتزمين علاقات مباشرة. وتلكك العلاقات مستقلة بعضها عن بعض، فلا تنشأ أي منها إستناداً على نشأة الأخرى، ولا تمثل أي منها سبباً لنشأة الأخرى. ورغم استقلال العلاقات المـكورة إلا بهمات

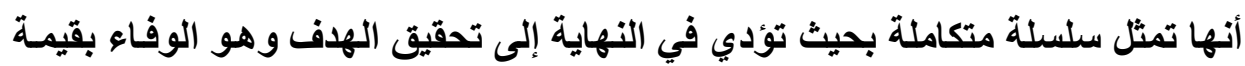
الورقة التجارية في ميعاد استحقاقها.

فالعلاقة بين الساحب والمستفيد التي يكون فيها الساحب مديناً والمستفيد دائناً،

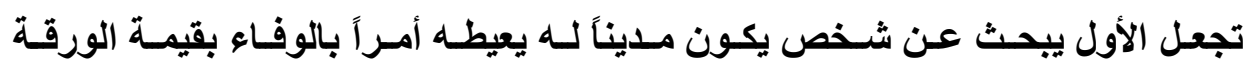

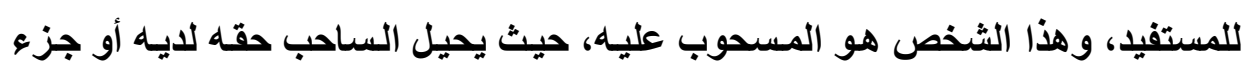
منه للمستفيد، ومن ثم فقد قامت علاقة بين الساحب والمسحوب عليه لتكمل العلاقة بين

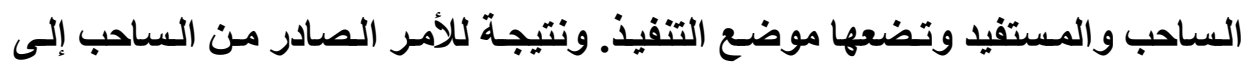
المسحوب عليه بدفع قيمة الورقة إلى المستفيد، تقوم علاقة لأول مرة أنشأتها الورقة ولم تكن قائمة قبل ذلك، وهي علاقة المسحوب عليه بالمستفيد، فيقوم الأول بالوفاء بقيمة الورقة للثاني، وتلك العلاقة تكمل العلاقة بين الساحب والمسحوب عليهه وتضعها موضع التنفيذ.

وتتحصر العلاقات التي تثتتمل عليها الورقة التجارية في تلك العلاقات الثلاث فقط عندما تكون الورقة لازالت في مرحلة سكون ولم يـتم إطلاقها في التداول بعد سواء بتسليمها للغير أو بتظهيرها لهن.

وبخروج الورقة التجارية من مرحلة السكون إلى مرحلة الحركة بتداولها، تبدأ نشأة

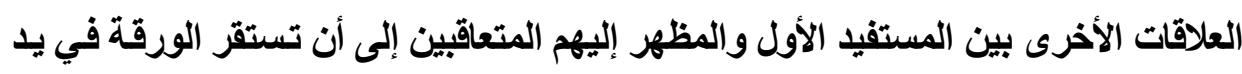

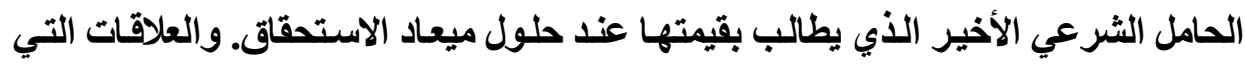

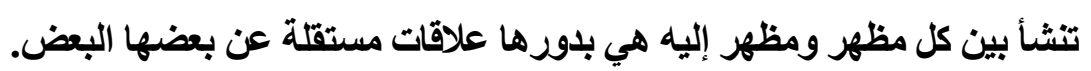


والحقيقة أن استقلال الالتزام الصرفي، بكل علاقاته، عن علاقة الأسـاس، بكل

مفرداتها، يجب أن تتم معالجته في مرحلة حركة الورقة وليس في مرحلة سكونها لمـا

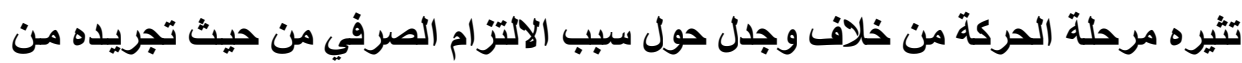
عدمه، وللارتباط الحتمي بين قاعدة تطهير الدفوع، التي لا توجد إلا في مرحلة حركة من فئ الورقة، وبين مسألة استقلال الالتزام الصرفي عن علاقة الأسـاس، فتلك القاعدة هي لوني التي تحكم هذا الاستقلال من عدمه حسبما سنرى لاحقًَ' (')

\section{الفزرع الثانتي}

\section{استقلال التوقيـعات الواردة على الورقة التجارية}

إن السبب الرئيسي لاستقلال العلاقات التي تشنتمل عليها الورقة التجارية راجع إلى

استقلال التوقيعات الواردة عليها. فمن أهم السمات التي تميز الالتزام الصرفي أن التوقيعات

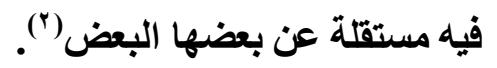

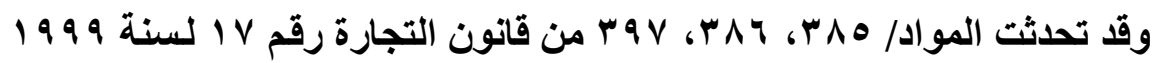

عند مبدأ استقلال التوقيعات الواردة على الورقة التجارية. فتنص المادة / مش ع على ما يأتي: الكون التزامات ناقصي الأهلية الأين ليسوا تجاراً وعديمي الأهلية الناشئة عن توقيعاتهم على الكمبيالة كساحبين أو قابلين أو ضامنين احتياطيين أو بأية صفة أخرى الإين باطلة بالنسبة إليهم فقطه

(1) (1) انظر لاحقاً ص 77 (1) وما بعدها.

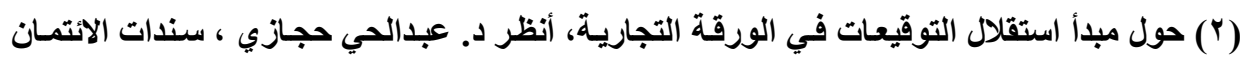

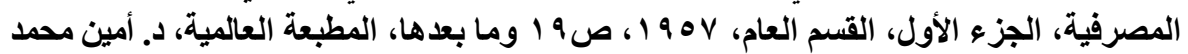

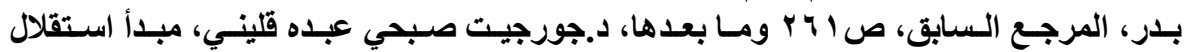

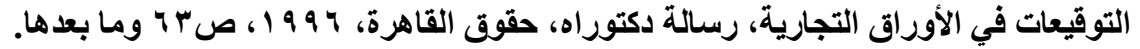




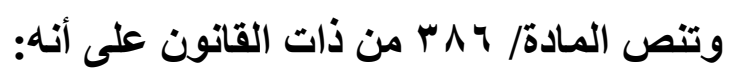

إإذا حملت الكمبيالة توقيعات أشخاص ليست لهم أهلية الالتزام بها أو توقيعات مزورة أو لأشخاص وهميين أو توقيعات غير ملزمـة لأسباب أخرى لأصحابها أو لمن

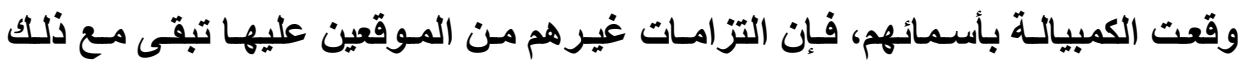

$$
\text { صحيحةه. }
$$

وتنص المادة / V ₹ من القانون المذكور على أنه:

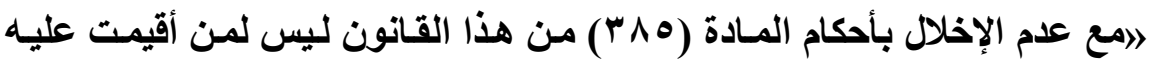
دعوى بكمبيالة أن يحتج على حاملها بالدفوع المبنية على علاقاته الشخصية بساحبها أو بحامليها السابقين ما لم يكن قصد الحامل وقت حصوله عليها الإضرار بالمدينها. ويقصد باستقلال التوقيعات في الالتزام الصرفي وفقاً للمواد سـالفة الذكر أنها إذا تعدد الملتزمـون بالورقة التجاريـة، فبان كل توقيع فيها مستقل بذاتـه عن التوقيعـات الأخرى، فيلتزم كل موقع على الورقة بالوفـاء بقيمتهـا بـالتزام مستقل تمامـاً عن بـاقي

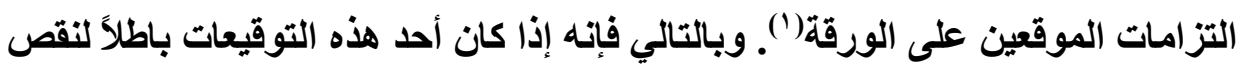

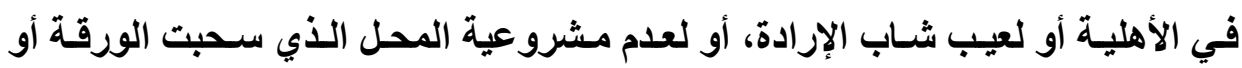
ظهرت بسببه، فإن هذا البطلان أو العيب لا ينسحب على التوقيعات الأخرى السابقة أو الو الو اللاحقة عليها، طالما أنها سحبت صحيحة. وقد قضت محكمة النقض الفرنسية بأنسه وفقاً للمـادة / ع 1 المن قانون التجـارة (القديم) إذا كانت الكمبيالة تحمل توقيعاً مزوراً، فـإن الالتزامـات الناثـئة عن التوقيعات الأخرى تكون صحيحة'(؟) (1) د.جورجيت صبحي عبده قليني، المرجع السابق، صه 1 وما بعدها. (2) Cass. Com. 21 dec. 1959, D. 196, J. 262 etss. 
ولقاعدة استقلال التوقيعات في الورقة التجارية العديد من التطبيقات منها أنسه إذا تم تغيير ميعاد الاستحقاق أو ثم تغيير مبلغ الكمبيالة أثناء مسيرتها، فيلتزم الموقعون اللاحقون لهذا التغيير به وإن لم يلتزم به الموقعون السابقون على حدوثي.

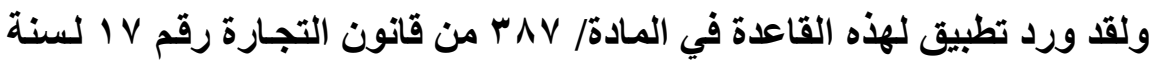
1999 199

\ا - يخضع شكل الالتزامات بموجب الكمبيالة لقانون الدولة التي صدرت فيها. ץ - ومع ذلك إذا كان الالتزام غير صحيح شكلاً بموجب القانون المشار إليه في الفقرة

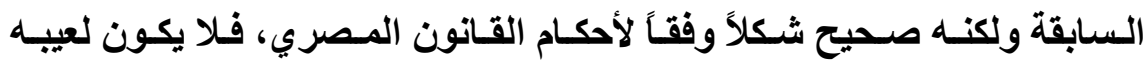
الثكلي أثر في صحة الالتزامات اللاحقة التي تنشأ بموجب الكمبيالة في مصربه. ومؤدي هذا التطبيق لمبدأ استقلال التوقيعات أنـه إذا كان التزام أحد الموقعين

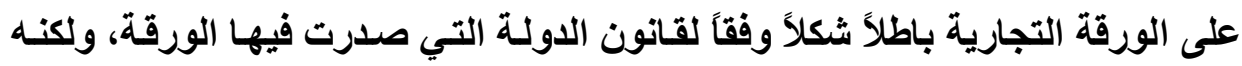
صحيح شكلاً وفقاً لأحكام القانون المصري، فإن هذا العيب الشكلي لا يؤثر على صحة

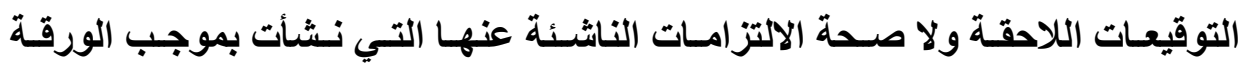
التجارية في مصر.

وهنـاك تطبيق آخر لمبدأ استقلال التوقيعات ورد النص عليه في المـادة / • ؟ ع فقرة/r من قانون التجارة، حيث يجري نصها على أنه:

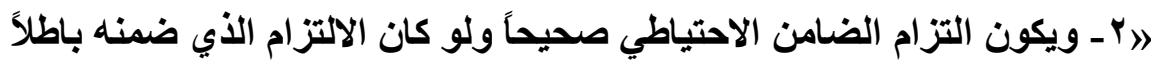

$$
\text { لأي سبب آخر غير عيب في الشكله. }
$$

ومؤدي هذا النص أن التزام الضامن الاحتيـطي يكون صحيحاً ولو كـان الالتزام المـضمون بـاطلاً بشرط ألا يكون هذا البطلان راجعـاً لعيب في الشكل. لأنسه إذا كـان 
الضامن الاحتيـاطي ملتزم بالأوجـه التـي يلتزم بهـا المـضمون، إلا أن التزام الضـامن الاحتياطي هو التزام صرفي يستمد قوته من ذات الصك الحامل له له

ويعتبر حكـم المـادة المـشار إليهـا خروجـاً علـى القواعـــ العامـة فـي الـضمـان

الاحتياطي التي تقضي بأن الضامن الاحتياطي يتبع التزام المضمون وجوداً وعدماً' '. ويرجع هذا الخروج إلى أن الضامن الاحتياطي يتحمل بالتزام صرفي، فهو مدين صرفي

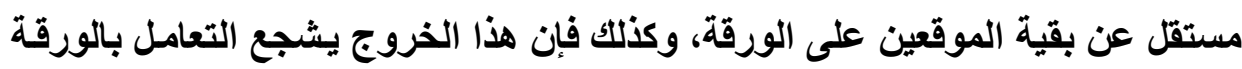
التجارية ويقوي ائتمانها.

وتجدر الإشـارة إلى أن قاعدة استقلال التوقيعات لا تتعارض مـع قاعدة تضامن الموقعين على الورقة وآثاره، لأن كل موقع، ولو أنسه ملتزم بالتضامن مـع غيره من الإن الموقعين الآخرين، إلا أن التزام كل موقع مستقل عن التزام الموقع الآخر، حيث يلتزم كل موقع بمقتضى سبب يختلف عن سبب التزام بقية الموقعين، فلكل التزام مصدره

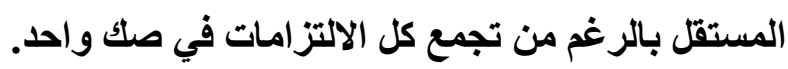




\section{المبحث الثالث}

\section{استقلال الالتزام الأصلي عن الالتزام الصرفي}

لم يشغل بال الفقه التجاري، ولم يثر بينهم خلافاً حساد بثأن مسألة من مسائل

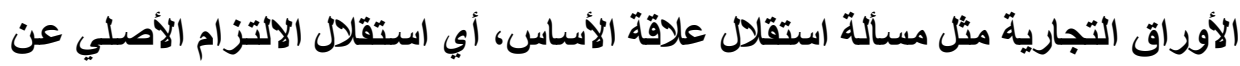

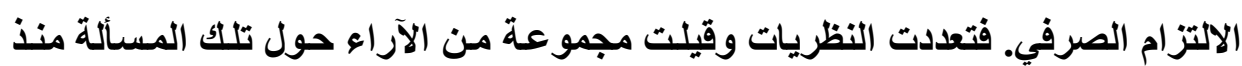

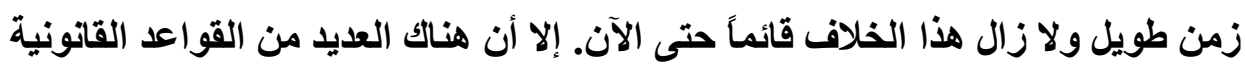

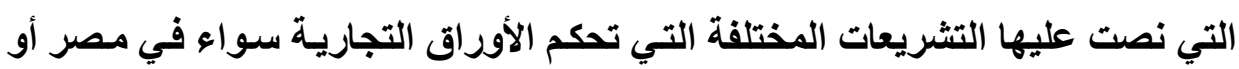

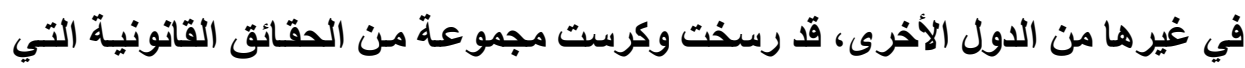

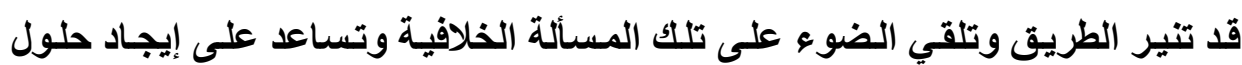

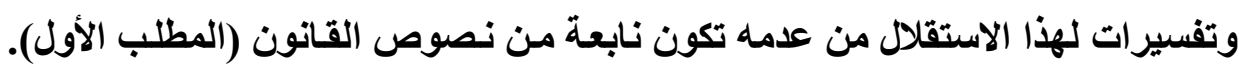

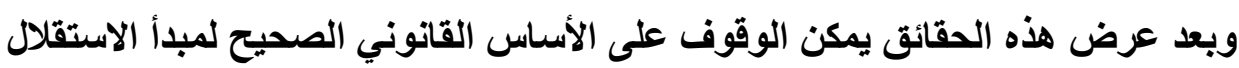

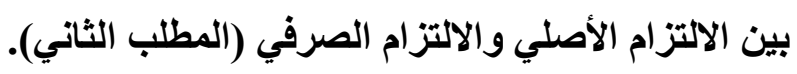

\section{المطاب الأول}

\section{حقائق قانونية تؤثر على هبدأ الاستقلال}

\section{وعلى أساسيه القانوني}

قبل مناقشة النظريـات والآراء العديدة التي قيـل بهـا تفسيراً لطبيعة الالتزام

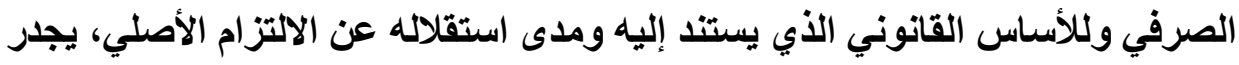

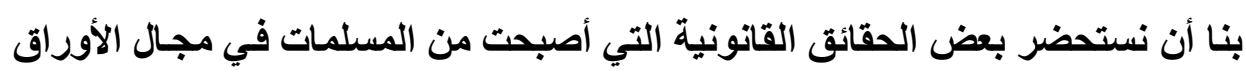

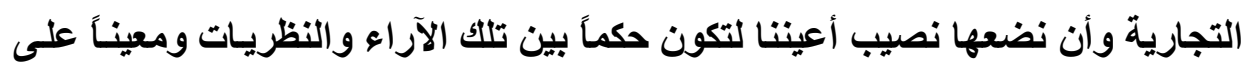
إيجاد الأساس السليم للالتزام الصرفي ومدى استقلاله عن علاقة الأساس. وتتمثل هذه 
الحقائق في سبب الالتزام عموماً وسبب الالتزام الصرفي على وجـه الخصوص (الفرع الأول)، وفي قاعدة تطهير الافوع (الفرع الثاني).

\section{الفرع الأول}

\section{سبب الالتزام الصرفي}

أركان الالتزامات عموماً، ومنها الالتزام الصرفي، ثُلاثة: الرضا والمحل والسبب.

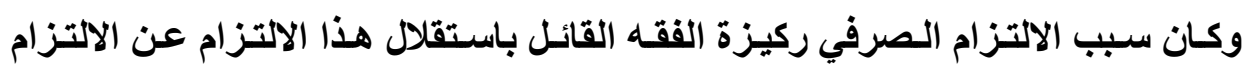
الأصلي استناداً إلى أن الالتزام الصرفي مجرد عن سبيه. إلا أنتا نبادر إلى القول أن لكل

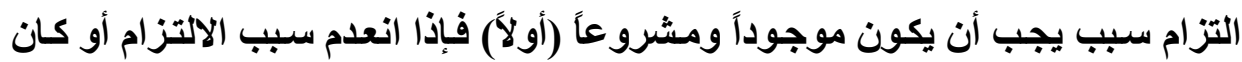
غير مشروع بطل الالتزام (ثانياً). أولاً: سبب الالتزام الصرفي مفترض في وجوده وفي مشروعيته: نظراً لعدم وجود نصوص خاصة بسبب الالتزام الصرفي فيطبق بشأنه النصوص

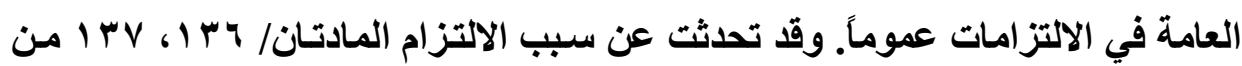
القانون المدني ويسري حكم هاتين المادتين على سبب الالتزام الصرفي. فتنص المادة/ بس ا المذكورة على أنه: إإذا لم يكن للالتزام سبب، أو كان سببه مخالفًاً للنظام العام والآداب، كـان العقد باطلاًه. وتتص المادة/ V ا المشار إليها على أنه: \ا ـ كل التزام لم يذكر له سبب في العقد يفترض أن لله سبياً مشروعاً، ما لم يقم الاليل على غير ذلك...ب. 
ومؤدي نص هاتين المادتين أن الالتزام لا بد أن يكون له سبب موجود ومشروع،

و إذا كان سبب الالتزام منعدماً أو غير مشروع بطل الالتزام لفقدانه أحد أركانه الثلاثة.

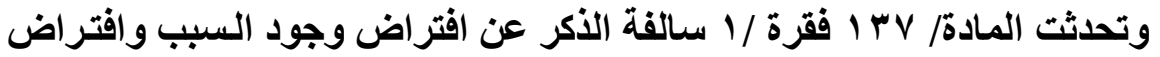

مشروعيته(') حيث قضت بأن الالتزام الذي لم يذكر لله سبب فيفترض أن سببه موجوداً

و مشروعاً.

إلا أن الققه(`) منذ وقت طويل وحتى الآن قد درج على استعمال تعبير بالنسبة

لسبب الالتزام الصرفي، هو أنـه التزام مجرد عن سببه Engagement abstrait. ولا يمكن تفسير هذا المصطلح بأن الالتزام الصرفي ليس لله سبب لأن هذا التفسير

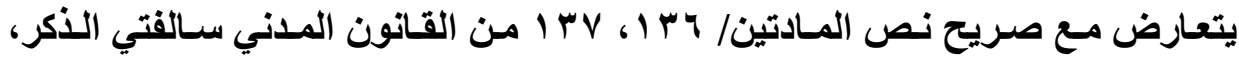
اللتان إشترطتا وجود سبب الالتزام ومشروعيته، وفي حالة عدم ذكر السبب فيفترض أنه موجود ومشروع إلى أن يثبث العكس.

ولذلك فإننا نرى ضرورة البعد عن استعمال مصطلح الالتزام المجرد عن السبب

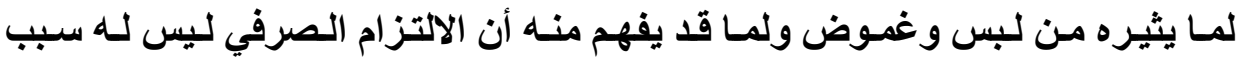
لمخالفة ذلك لصريح نصوص القانون المدني سـالفة الذكر والمتعلقة بسبب الالتزام بوجه عام.

ونفضل اسـتعمال مـصطلح أن "سـبب الالتـزام الـصرفي مفتـرض في وجـوده ومفترض في مشروعيته إلى أن يثبت عكس ذلك". ونفضل استعمال هذا المصطلح

(1) M. CABRILLAC, la letter de change dans la jurisprudence, librairies techniques, 1978, p. 17 etss.

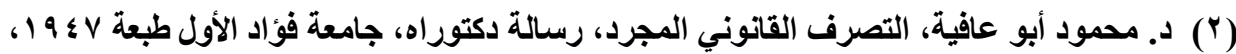
مطبعة جامعة فؤاد الأول، وغالبية فقه القانون التجاري يستعمل مصطلح الالتزام "المجرد عن التهن 
سواء اعتبرنا أن سبب الالتزام الصرفي هو عقد الأساس أو أن سببه هو إقرار الملتزم

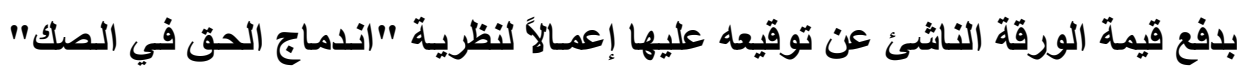
التي قال بها بعض الفقه، ولنا عودة إلى هذه المسألكة لاحقًاً (1).

وكان سبب الالتزام الصرفي متمثثلاً في ظل قانون التجارة الملفي في ذكر بيان

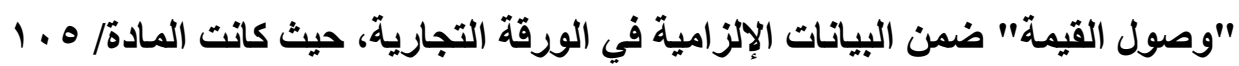

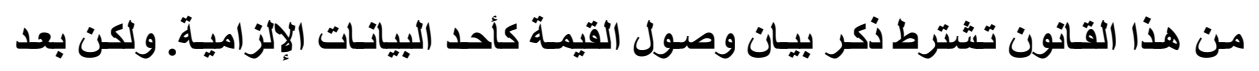

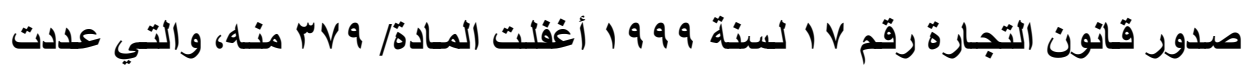

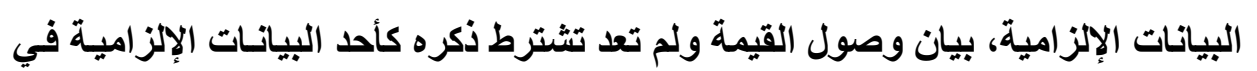

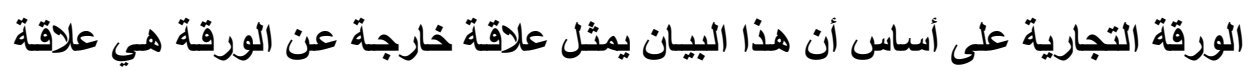
السـاحب بالمستفيد أو المظهر بـالمظهر إليـه، إلا أن ذلـك لا يحول دون اعتبـار بيـان وصول القيمة من البيانات الاختيارية التي يجوز لأي من الموقعين على الورقة إدراجها

وأثناء مناقشة قانون التجارة رقم V V لسنة 999 1 في مجلس الشعب، اقترح

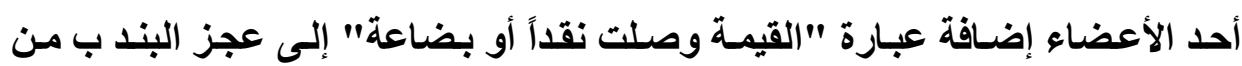

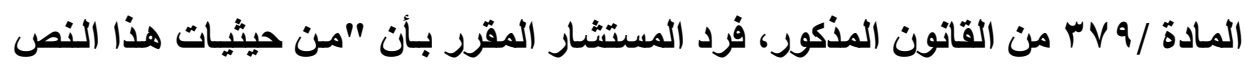

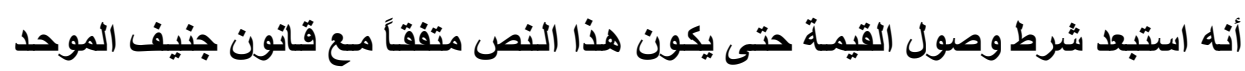

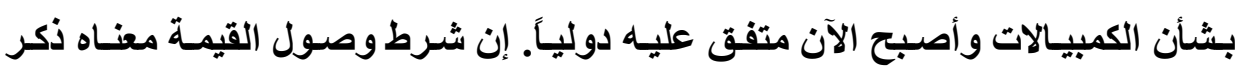

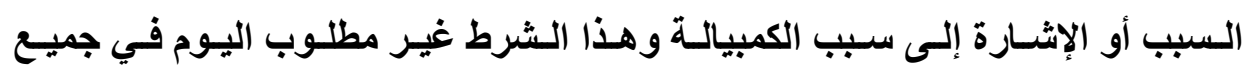

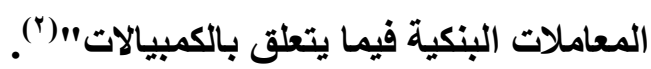


وقد كان من شأن عدم اشتر اط ذكر بيان وصول القيمة كأحد البيانات الإلزامية في

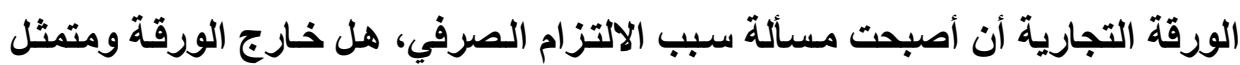

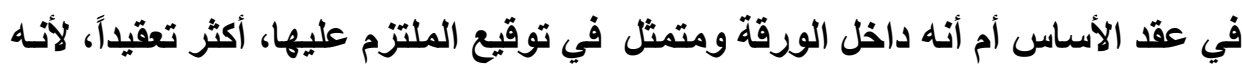

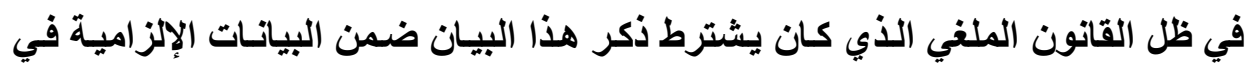

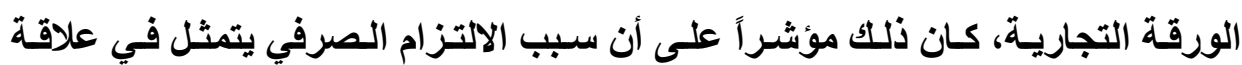

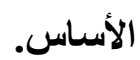

وإن كـان ذكر بيـان وصـول القيمـة مـن عدمهـ يـؤثر على تحديد سبب الالتزام

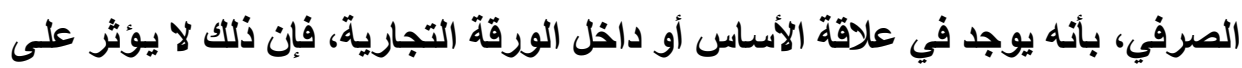

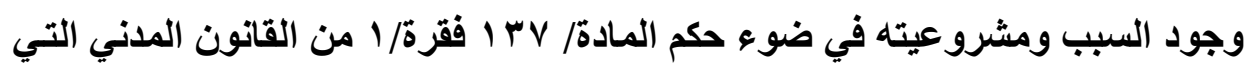

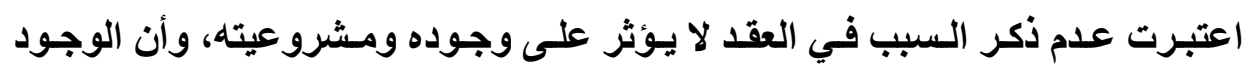
والمشروعية مفترضان إلى أن يثبت العكس.

وثمة تعليق أخير على رد المستثار ممثل الحكومة على إغفال ذكر بيـان وصول

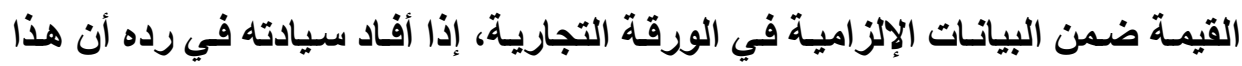

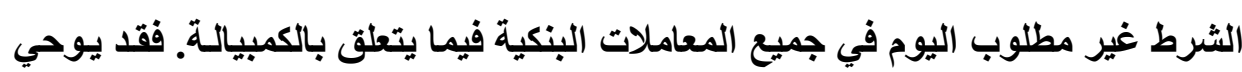
هذا الرد أن ممثل الحكومة يقصد تعاملات البنوك فيما يتعلق بالكمبيالة بثأن خصمها.

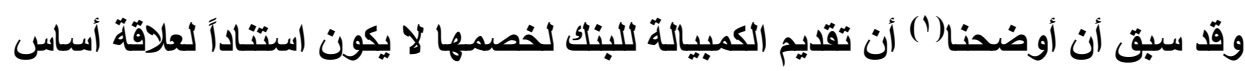

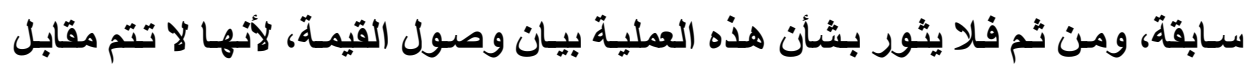
وصول قيمة. وتلكك حالة نادرة لا يوجد فيها علاقة أساس. ونحن نرى أنه كلان يجب على المشرع الإبقاء على بيـان وصول القيمة كبيان

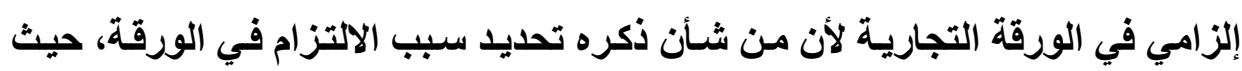


يكون متمثّلًا في علاقة الأساس وهذا سيقضي على الخلاف المحتدم حو المقصود بسبب

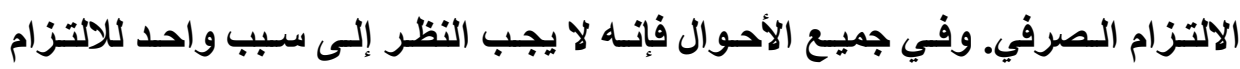

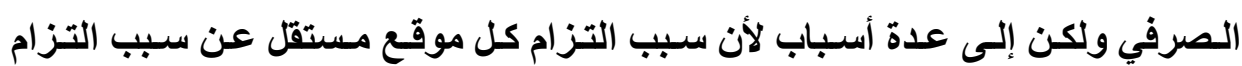

ثانياً: حالات انعدام سبب الالتزام الصرفي أو عدم مشروعيته:

لا بـ أن يكون للالتزام الصرفي سبب قائم ومشروع، وذكرنـا أن العبارة التقليديـة التي درج الفقه على استعمالها أن الالتزام مجرد عن السبب هي عبارة غير دقيقة وتثير

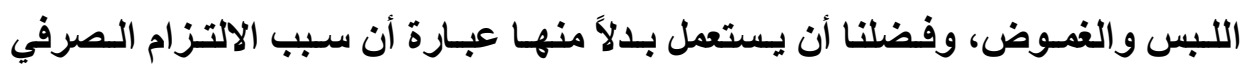
مفترض في وجوده (1) ومفترض في مشروعيته (ץ). فالقول بأن الالتزام الصرفي

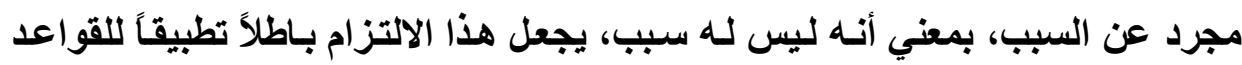

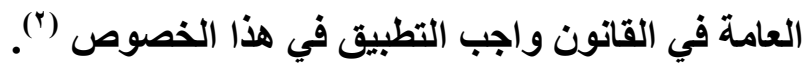
(1) علم وجود سبب الالتزام الصرفي:

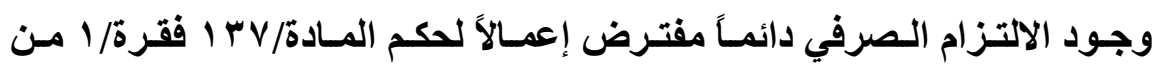

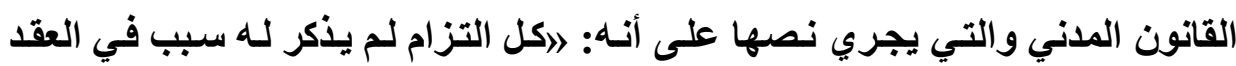

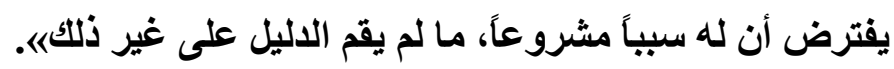
فعدم ذكر سبب الالتزام الصرفي لا يعني أنه غير وجود، حيث يفترض وفقاً للمادة المذكورة أنه موجود، فقد أقامت هذه المادة قرينة على وجودئه، إلا أنها قرينـة بسيطة تقبل إثبات العكس، إذ ذكرت المادة المشار إليها في عجزهـا عبارة "مـا لم يقدم الدليل

(1) M. Cabrillac. Op. cit. p. 17. 
على غير ذلك". ومن ثم فمن يدعى أن السبب غير موجود يقع عليه عبء إثبات عدم

ولغياب سبب الالتزام الصرفي عدة صور نذكر منها على سبيل المثال كمبيالات

$$
\text { المجاملة ( أ ) وزوال السبب قبل نشوء الالتزام الصرفي (ب). }
$$

( أ ) كمبيالات المجاملة: Les effets de complaisance

قد يحدث أحيانًا أن يختل ائتمان التاجر ويتأزم وضعه المـادي على نحو تتضاعل

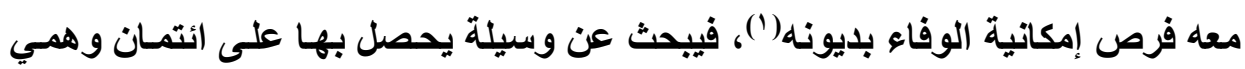
لإخفاء عجزه المالي، فيلجأ إلى ما يسمى "بكمبيالة المجاملة". ولم يتناول المشرع المصري صراحة هذا النوع من الكمبيالات، مثله في ذلك مثل كافة التثريعات لأن هذا النوع من الكمبيالات أفرزته الحياة التجاريـة بوجهه عـام. إلا أن

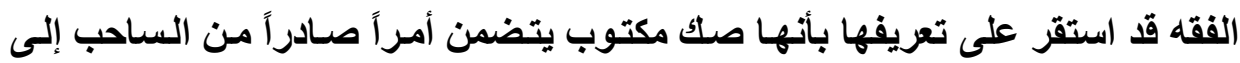

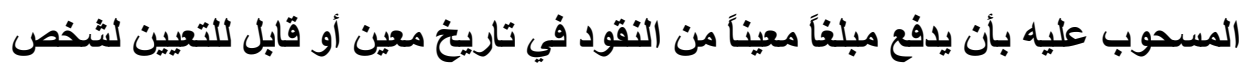

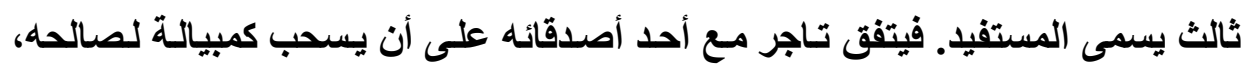

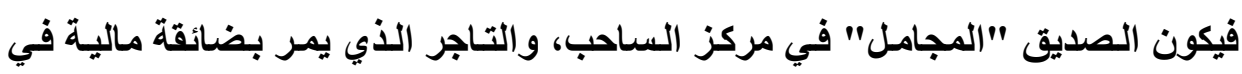
مركز المستفيد، وتقدم تلك الكمبيالة إلى المسحوب عليه لقبولها إمعاناً في خلق ائتمـان وهمي ظاهر لصالح المستفيد بقصد اجتذاب ثقة الأغيار فيها. ويقوم هذا المستفيد من المجاملة بخصم الورقة لاى أحد البنوك أو تظهيرها لتحصيل قيمتها.

(1) انظر مقال بعنوان: كمبيالات المجاملة وأثرهـا على الاتتمسان والتداول التجاري، منشور على http://www.mohamoon/montada/default.aspex?action=Display 
وتلك الكمبيالة لا تستتد إلى وجود علاقة ما بين الساحب والمستفيد، حاضرة أو مستقبله. أي أنها لا تستند إلى سبب مسا سـوى المجاملـة. فتوقيع الساحب على هذه

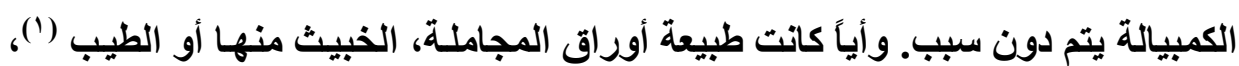
فإنه من المستقر عليه بطلان تلكك الأوراق وذلك لانعدام سببها (「). ويقترب هذا النوع من الكمبيالات من نوع آخر وهو الكمبيالة التي تسحب على شخص وهمي وتسمى "السحب في الهواء"، والتي تسحب على غير مدين وتسمى هنى

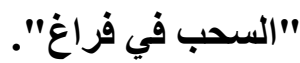

وفي كمبيـالات المجاملة لا يوجد مقابل وفاء للساحب في ذمـة المسحوب عليه التي قبلها رغم ذلك. إلا أن الساحب في النهايـة هو الملتزم بتوفير مقابل الوفاء عند

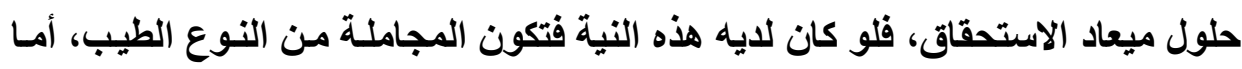

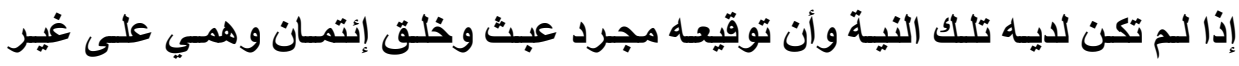

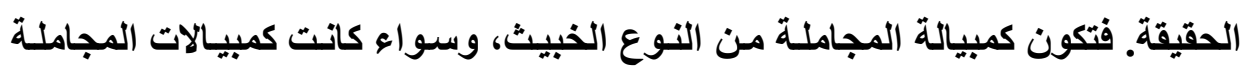
من النوع الطيب أو الخبيث، فإنها باطلة لانعدام سبيها. وتجدر الإشارة هنا إلى أنـه لا مجال للحديث عن استقلال كمبيالة المجاملة من

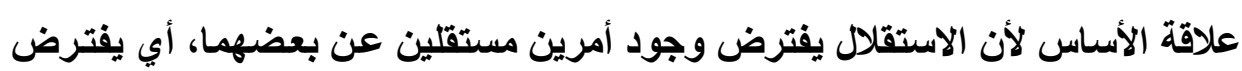

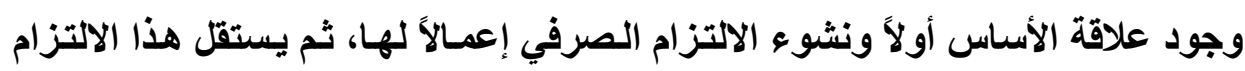

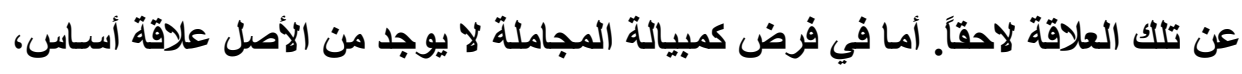

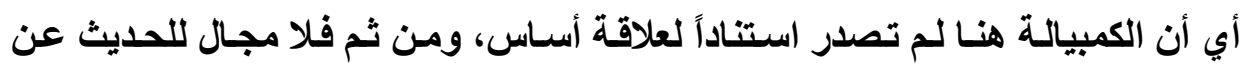
استقلال الالتزام الصرفي عن علاقة الأساس غير الموجودة الصادة أصلاً.

(1) Cass. Com. (Req) 18 oct. 1943. S. 1944, p. 1 a 18.

(2) Ch. Gavalda et j. stoufflet, cheques et effets de commerce, Paris 1979. p. 90 et 91. 
غير أن هذا البطلان بالنسبة لكمبـالات المجاملـة إذا كـان أكيداً بين أطراف

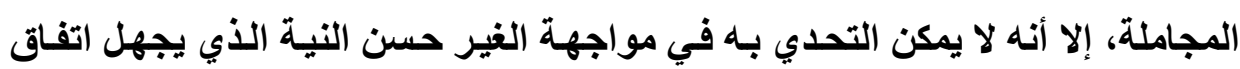

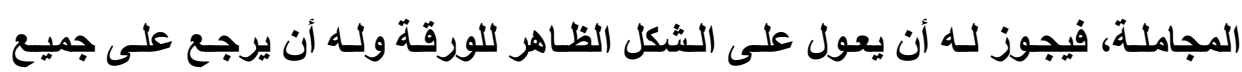

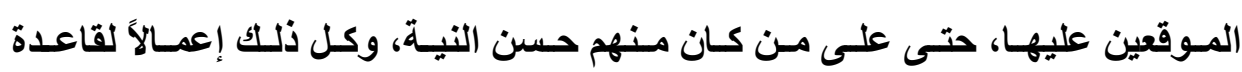

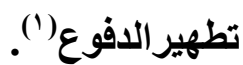

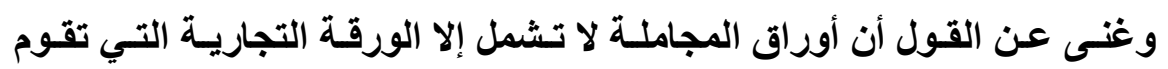

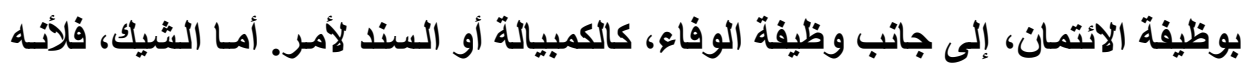
أداء وفاء فقط، فلا يكون محلاً لأوراق المجاملة. (ب) زوال السبب قبل نثوء الالتزام الصرفي:

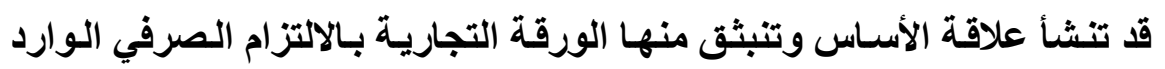

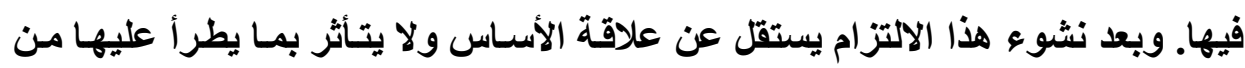

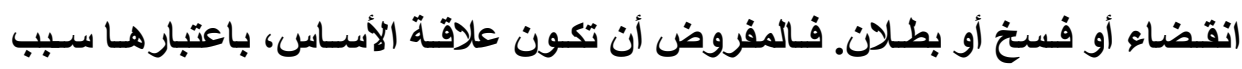

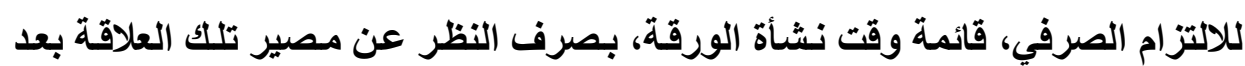
ذلك.

أما إذا كاتت علاقة الأساس قد زالت لأي سبب من الأسباب كالانقضاء أو الفسخ أو البطلان، قبل نثأة الكمبيالة، فإن الالتزام الصرفي الوارد في الكمبيالة يكون قد نشأ

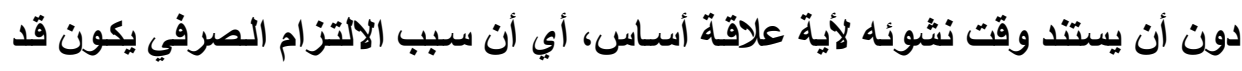
زال وقت نثأة الورقة، فيكون الالتزام الصرفي هنا باطلاً لانعدام سبيه. 
وقد أصدرت محكمة النقض الفرنسية حكماً في هذا الخصوص بتـاريخ ^ ب مسايو

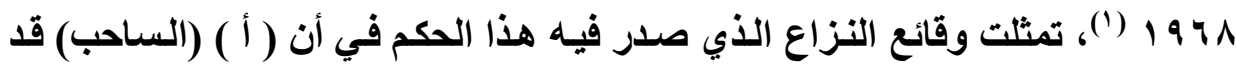

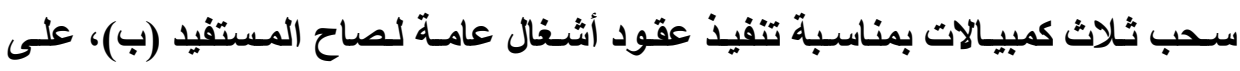
المسحوب عليه (ج). وكانت تلك الكمبيالات صادرة بتاريخ ؛ مسارس ؛ ج 9 1، في حين

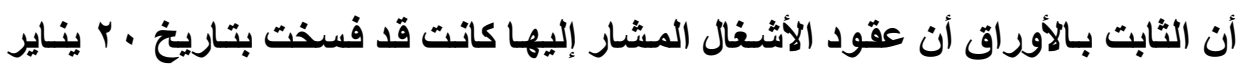

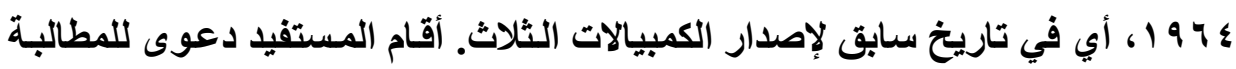
بقيمة تلك الكمبيالات فقضت محكمة الاستئناف بأن هذا المستفيد كان حامل سيء التئية

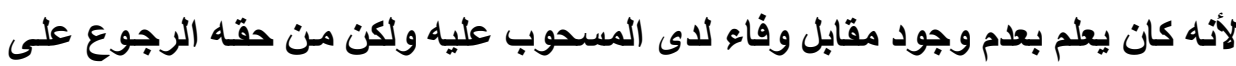
الساحب باعتباره ضامناً للوفاء بقيمة الكمبيالة. طعن على هـا الحكم أمسام محكمـة النقض، وتمسكك الطـاعن بـأن سـبب تلـك الكمبيالات بما ورد فيها من التزام صرفي لم يكن قائماً وموجوداً وقت نشأة الكمبيالات،

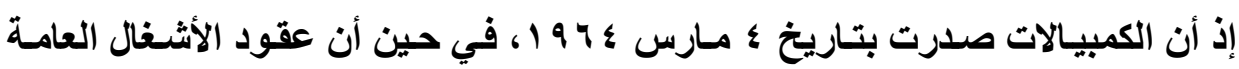

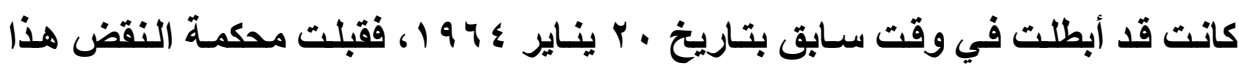
الطعن وقضت بإلغاء الحكم المستأنف وإبطالـه تأسيساً على أنه لـ يطبق على على النزاع القاعدة القانونية السليمة، إذ أن وقت نشوء الالتزام الصرفي كانت علاقة الأسـاس قـ أبطلت، فنشأ الالتزام الصرفي عن سبب ليس له وجود وقت نشأتها. إلا أن هذا البطلان، وإن كان أكيداً بين أطراف علاقة الأسـاس والالتزام الصرفي

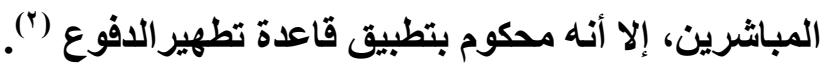

(1) Cass. Com. 28 Mai 1968. bull. Civ. 1968, IV. No 170.

(2) M. Cabrillac. Op. cit. p. 18. 


$$
\text { (r) عدم مشروعية سبب الالتزام الصرفي: }
$$

إن البحث عن سبب التزام الساحب في الورقة التجارية، وأي ملتزم لاحق للوفاء

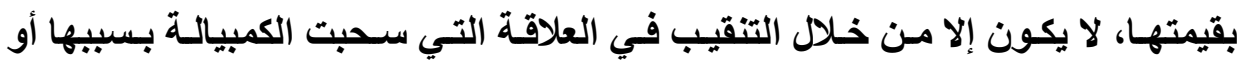
بمناسبتها وهي علاقة الأساس التي تربط بين الساحب والمستفيد، وهذا مـا كـان يعبر

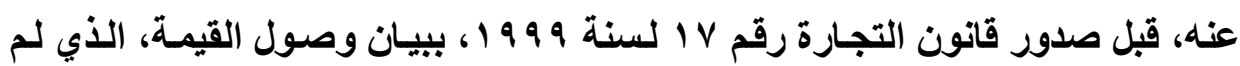
يعد القانون المذكور يستلزم ذكره ضمن البيانات الإلزامية في الكمبيالة. فإذا كان سبب التزام الساحب، بمفهوم الباعث الدافع، غير مشروع بأن يذكر أن القيمة وصلت بضاعة والحال أن الكمبيالة حررت تسوية لدين قمسار أو رشوة أو ثمنـاً لارتكاب جريمة أو لإقامة علاقة جنسية غير مشروعة(')، فإن التزام الساحب يقع بـاطلاً

$$
\text { لعدم المشروعية. }
$$

ومسن البـيهي أن توقيع السـاحب على الكمبيالـة يعتبر قرينـة على مشروعية

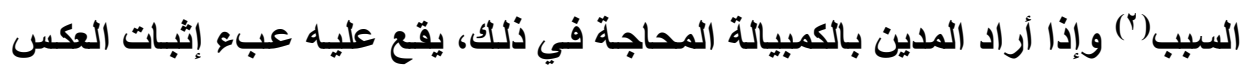

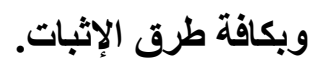

وتجدر الإشـارة إلى أنسه لا يمكن التحدي ببطلان السبب لعدم المشروعية أمسام الحامل حسن النية الذي انتقلت إليه الورقة ولا يعلم بعدم مشروعية سبب الالتزام وذلكت بلكئل إعمالاً لقاعدة تطهير الدفوع. وكذلك فإنه بإطلاق الكمبيالة في التداول، وتطبيقًا لمبدأ استقلال التوقيعات، تعتبر التوقيعـات اللاحقـة لهـا سـبب موجـود ومسشروع، ويلتـزم أصـــابها بالوفـاء بقيمـة

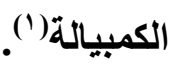

(1) Cass. Civ. 11 Mars 1918, d. 1918.1. 100.

(2) Cass. Com. 25 Mars 1974. R. T. D. Com. 1974. p. 558 et 559. 


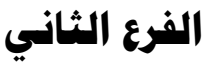

\section{قاعدة تظهيرالدفوع}

\section{L'inopposabilité des exceptions}

إن قاعدة تظهيرالدفوع التي قررها القانون في مجال التعامل بـالأوراق التجاريـة

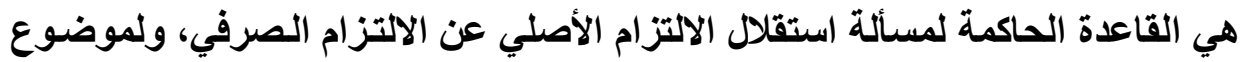

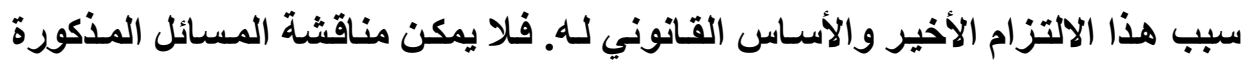

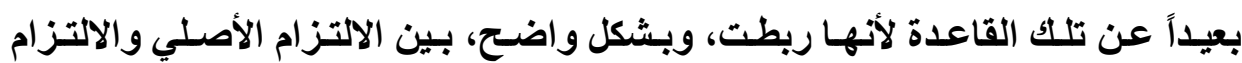
الصرفي، فقررت استقلالهما في بعض الأحيان والارتباط بينهما في أحيان أخرى. ويبين مدى أثر قاعدة تظهير الدفوع على مبدأ استقلال الالتزام الأصلي عن

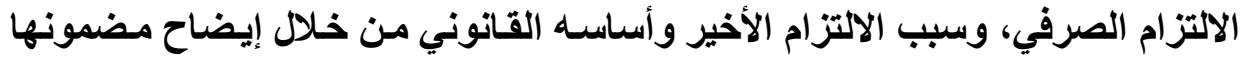

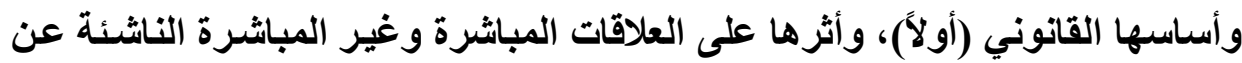
التعامل بالورقة التجارية (ثُانياً). أولاً: مضمون قاعدة تظهير الدفوع و أساسها القانوني: تنشأ الكمبيالة ابتداء بين ثلاثة أثخاص يرتبطون معاً بعلاقات مباشرة، ويعرفون بعضهم بعضاً. فتوجد علاقة بين الساحب الذي أنثأ الكمبيالة وضمنها بياناتها الإلزامية والمستفيد منها، وترتد تلك العلاقة بجذورها إلى علاقة أخرى قامت بينهما قبل إصدار

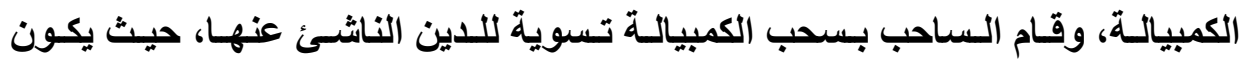
الساحب في تلكك العلاقة السابقة مديناً والمستفيد دائناً، وهي ذات صلات صفتهما في الكمبيالة،

(1) Cass. Com. 4 Juil 1966. d. 1967, J. 144; Cass. Com. 15 Mars 1974. R. T. D. Com. 1975. p. 558. 
فالسـاحب مـدين بمبلغها والمستفيد دائن بهـا المبلـغ وهـي علاقـة مباشرة. والعلاقة الثانية التي تشملها الكمبيالة تربط بين الساحب والمسحوب عليه، يكون فيها الأول

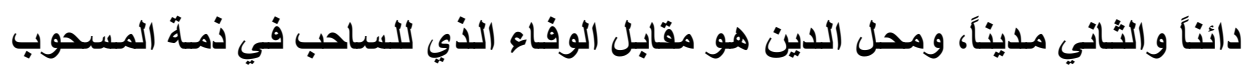
عليه، وهو المبلغ الذي يافعه المسحوب عليه إلى المستقيا بنـاء على أمر صـادر إليه

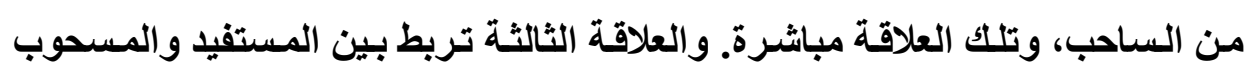

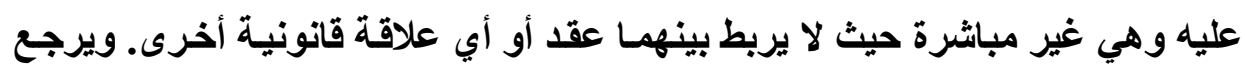
المستفيد على المسحوب عليه ليحصل على قيمسة الكمبيالـة، ويقوم المسحوب عليه إيه بالدفع تنفيذاً للأمر الصادر إليه من الساحب لكونه مديناً لهذا الأخير. وطوال فترة وجود الكمبيالة في حالة سكون واقتصارها على تلك العلاقات الثثلاث وعدم انضمام أشخاص من الغير إلى أطرافها الثلاثة المذكورين، فإنسه لا مجـال لحدوث مفاجآت عند المطالبة بقيمة الكمبيالة عند حلول ميعاد الاستحقاق، وذلك لكون علاقات إلكات

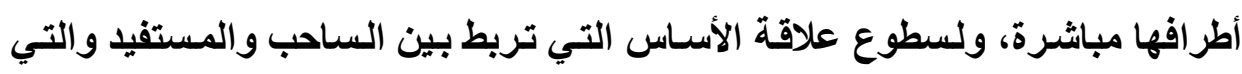

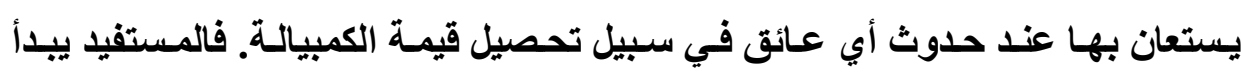
بالرجوع على المسحوب عليه بلا أدنى صعوبة إذا كان هذا الأخير قد قبل الكمبيالة، أمسا

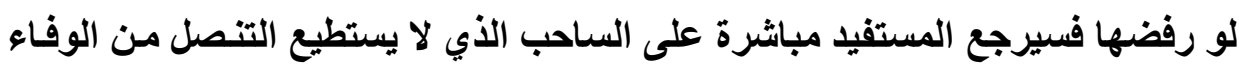

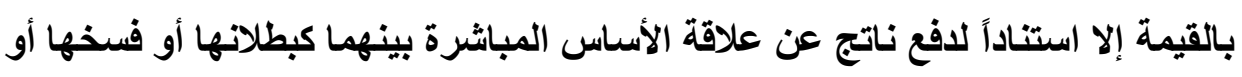

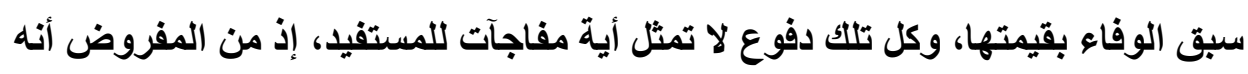
يعلمها جيداً لتعلقها وإرتباطها بعلاقة مباشرة بينه وبئ وبين الساحب. إلا أن الأمر يكون جد مختلف إذا انتقلت الكمبيالـة من طور السكون إلى طور

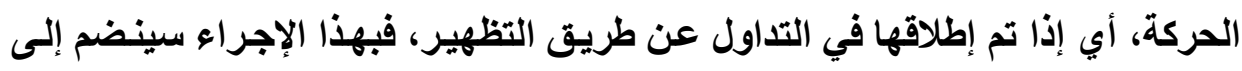
ركب الكمبيالة أشخاص من الغير، غربـاء عن الكمبيالة يجهلون أصل نشأتها وحقيقة

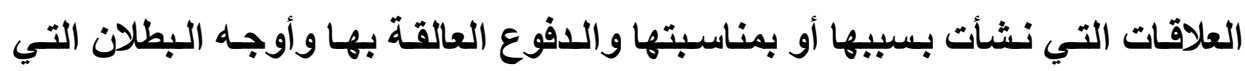

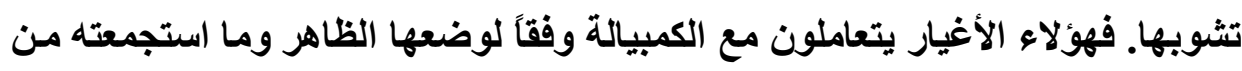


بيانات إلزامية تطلب القانون اشتمالها عليها، فكل مـا يعنيهم ويعتمدون عليه في هذا التعامل هو صحة الكمبيالـة مسن حيث الظـاهر، واستيفائها لشروط صحتها الشكلية، لاسيما في ظل اهتمام المشرع واعتماده على الشكلية المفرطة، وتوافرها في الكمبيالة كأساس لتداولها والتعامل بها.

ومن يتلقى من الغير كمبيالة ـ تبدو في ظاهرهـا صحيحة ـ يتولد لايـه اعتقاداً

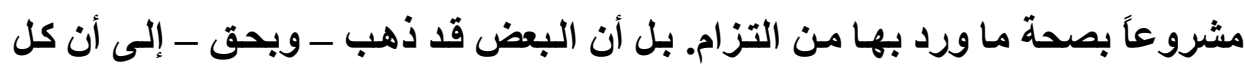
حائز شرعي لصك يكون لله حق مطلق بل وجديد في اقتضاء قيمته(') ولن تستطيع الكمبيالة أداء وظيفتها كأداة وفاء، تقوم مقام النقود في الوفاء، إذا

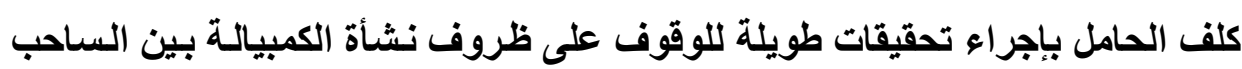

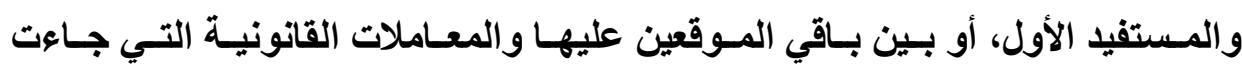
الكمبيالة تسوية لها. وهذا كله مؤداه أنه يجب حماية الغير حسن النية الذي انضم لركب الكمبيالـة دون

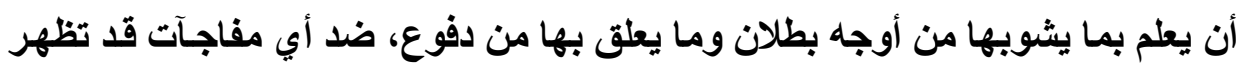

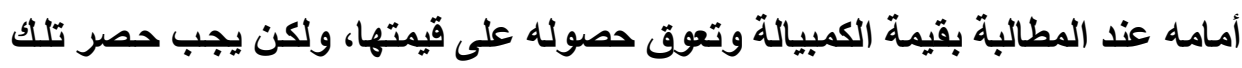
الحماية في حالة رجوع الغير (الحامل الثرعي) على دائنه غير المباشر، ووسيلة تلك ونك

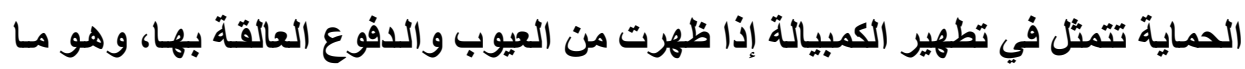
يطلق عليه"قاعدة تطهير الدفوع". فالأساس القانوني إذن الذي ترتكن عليه هذه القاعدة يكمن في فكرة الظاهر التي تقوم عليها معظم الأبنية القانونية التجارية. (1) مارين، الاحتجاج بالدفوع، مشار إليه لاى د. أبو زيد رضوان، الأوراق التجارية، المرجع السابق، 
وتجدر الإثـارة إلى أن تلك القاعدة، على أهيتها وعلى الرغم من أنها تعد

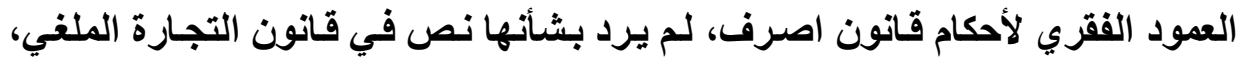

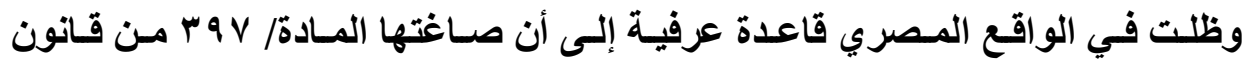
التجارة الحالي التي تنص على أنه:

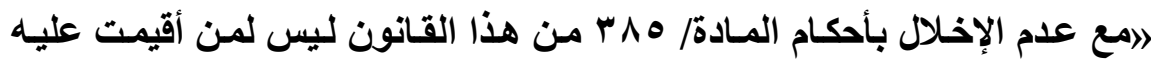

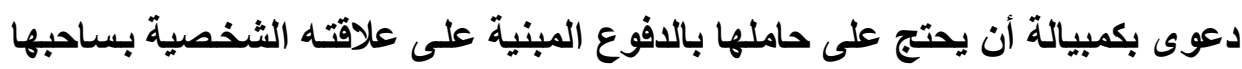
أو بحامليها السابقين ما لم يكن قصد الحامل وقت حصوله عليها الإضرار بالمدينها. ثنانياً: أثر تطبيق قاعدة تطهير الدفوع على العلاقات المباشرة وغير المباشرة الناثئة من الورقة التجارية:

يختلف أثر تطبيق قاعدة تطهير الدفوع على العلاقات بحسب ما إذا كانت مباثرة أو غير مباشرة (1) وهذا الأثر يرتبط بمسألة الأساس القانوني لعدم تطبيق تلك القاعدة

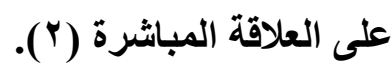
(1) تطبيق قاعدة تظهير الدفوع على العلاقات المباشرة وغير المباشرة: تنص المادة/ q ب من قانون التجارة، على أنه:

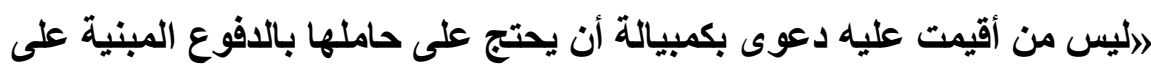
علاقته الثخصية بساحبها أو بحامليها السابقين.....). وقد ذكرنـا سـلفاً أن الهـف مـن قاعدة تطهير الدفوع هو حمايـة الحامـل في

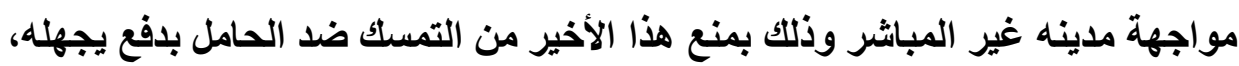

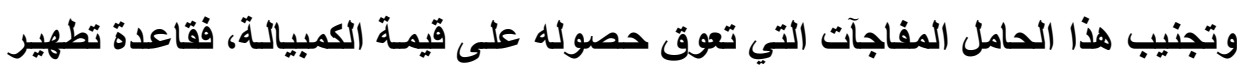

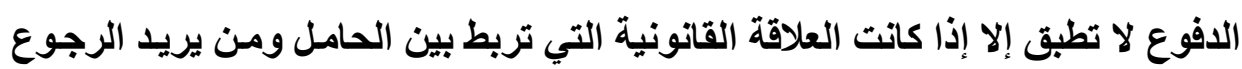
عيك من الملتزمين بالورقة علاقة غير مباشرة. 
ولذلك، وإعمالاً للنص المذكور، فإنـه لا يجوز لأي من الملتزمين بالكمبيالة أن

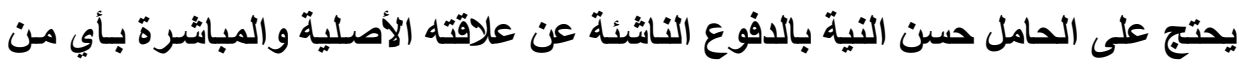

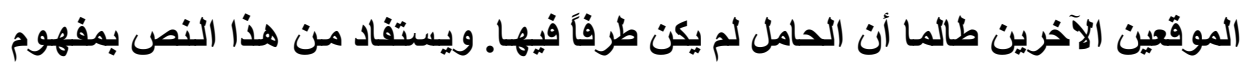

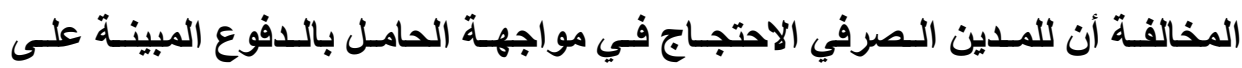

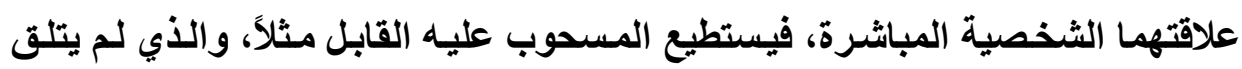

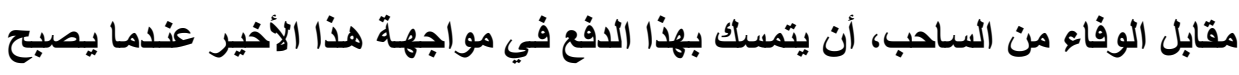

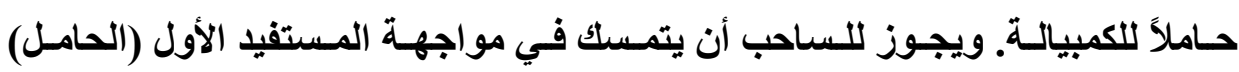
بانقضاء علاقة الأساس بينهما أو فسخها أو تنفيذها لأن الافع ناشئ عن علاقة مباشرة

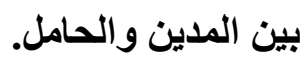

والعلة من عدم استفادة الحامل من قاعدة تطهير الدفوع وعدم استطاعته التمسك

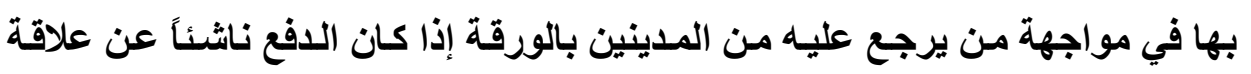

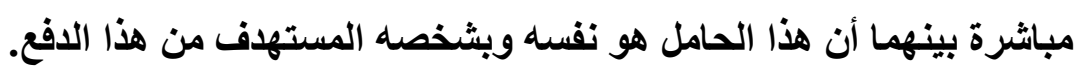
وتجدر الإثـارة إلى أن بعض الفقهـ لا يتــاول شرط ألا يكون الحامل طرفاً في

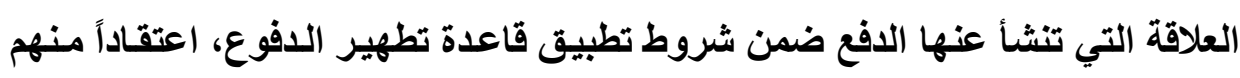

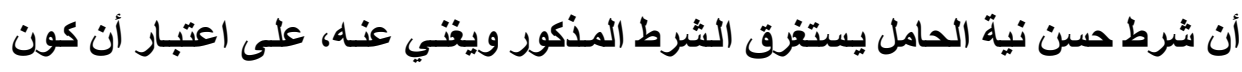

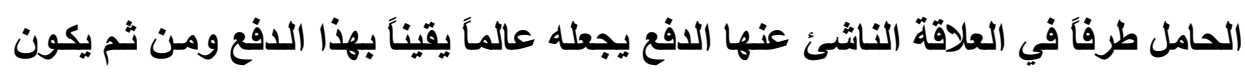
سيء النية ولا يستفيد من القاعدة المذكورة.

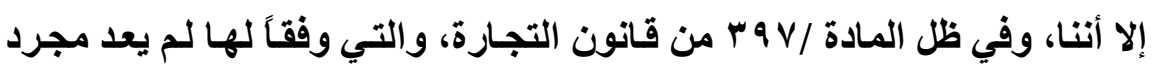

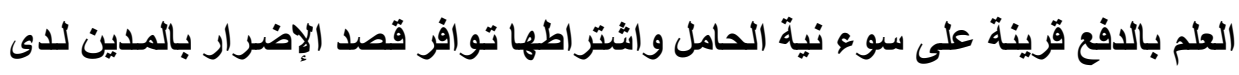
الحامل، نرى أنه يجب دراسة الثرط المشار إليه على استقلال.

فقاعدة تطهير الدفوع - في نظرنا - تعمل في حالة عدم وجود علاقة مباثرة بين

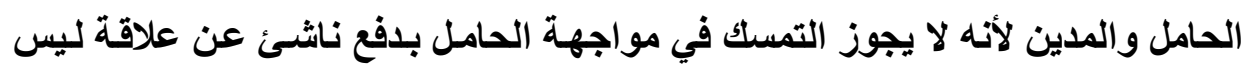


طرفاً فيها، وأمسا إذا كاتت هناك علاقة مباشرة بين الحامل والمدين فيحدث ارتباط بين

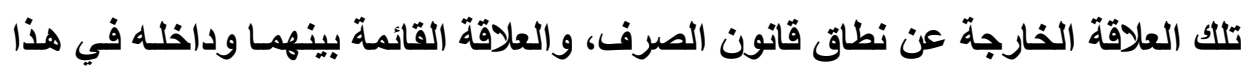
النطاق، ويتم التسوية بين العلاقتين في ضوع ما ينشأ عنهما من دفوع لكل من المدين

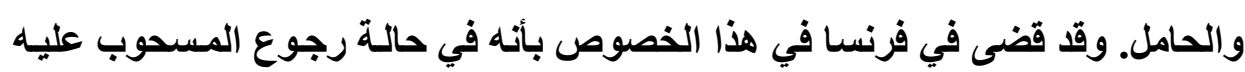
أو المستفيد على الساحب الذي سحب الكمبيالة لصالح هذا المستفيد مقابل قيمـة تلقاهـا

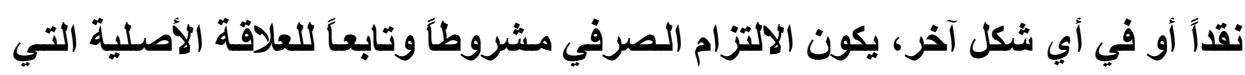

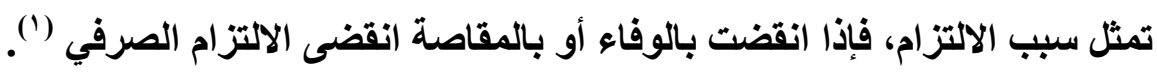
ويناءً على ما سبق فإن المدين بالالتزام الصرفي يظل لـه الحق في التمسك بـأي دفع ناشئ عن علاقة مباشرة بينه وبين الحامل حتى لو انتفى قصد الإضرار بالمدين بالين

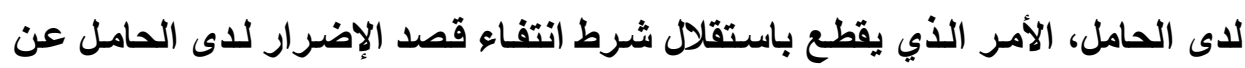

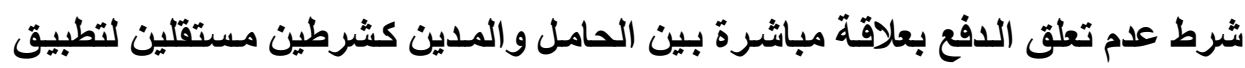
قاعدة تطهير الدفوع.

خلاصة القول أن قاعدة تطهير الدفوع لا تطبق على الدفوع الناشئة عن العلاقات

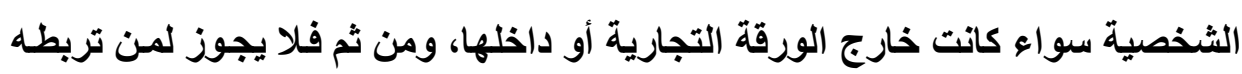
علاقة مباشرة من الملتزمين بالوفاء بقيمة الورقة وصاحب الحق فيها أن يتمسك بأيسة

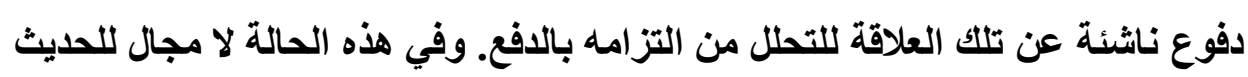
عن استقلال الالتزام الأصلي عن الالتزام الصرفي، ويكون الالتزام الأول أساساً للالتزام الثاني وسبباً له.

أما إذا كاتت العلاقة بين الملتزم بالوفاء بقيمة الورقة وصساحب الحق فيها علاقة

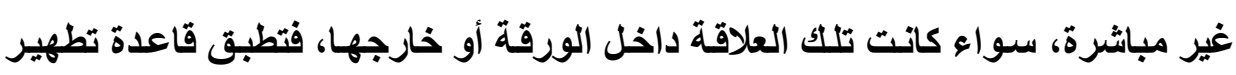
الدفوع على الدفوع الناشئة عن هذه العلاقة، ومن ثم فلا يجوز للملتزم بالوفاء التمسك

(1) Paris 16/6/1986. D. 1986. inf. Rapid. P. 12. 
في مواجهة صاحب الحق في الورقة بأية دفوع ناشئة عن تلك العلاقة غير المباشرة. وفي هذا الفرض، وفي ضوء تطبيق قاعدة تطهير الدفوع، يكون الاستقلال واضحاً بين الالتزام الأصلي والالتزام الصرفي. وهذا الاستقلال يجد سببه في تطبيق قاعدة تطهير

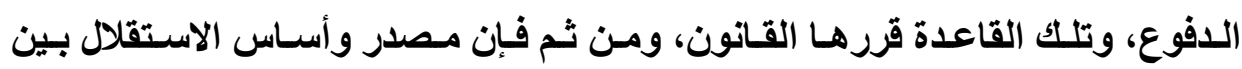

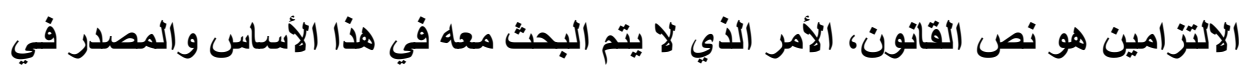

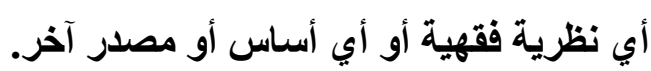

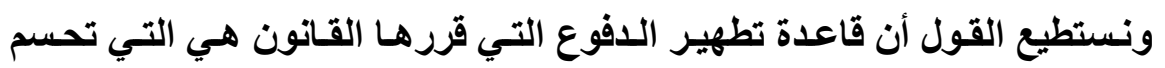

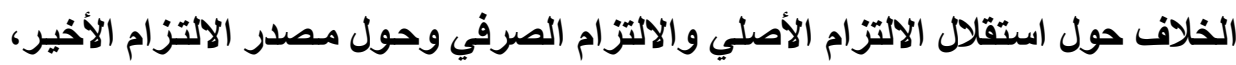

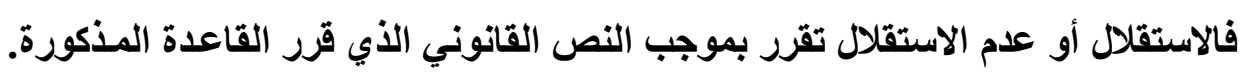
ولذلك فإن تأثير تلك القاعدة على مبدأ الاستقلال من عدمه هو تأثير مباشر.

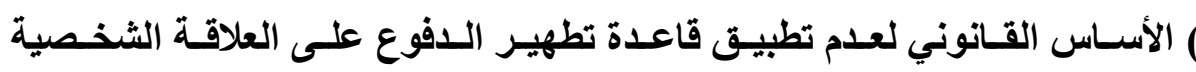

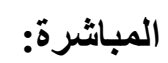

يتمثل الأساس القانوني لعدم تطبيق قاعدة تطهير الدفوع على العلاقة الثخصية

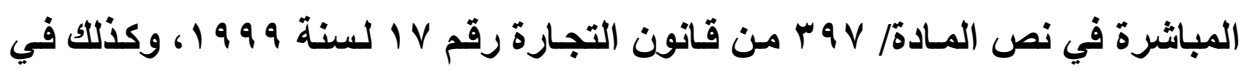

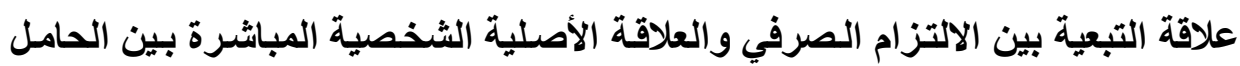

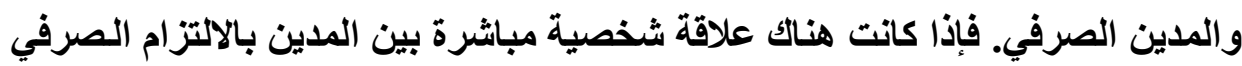

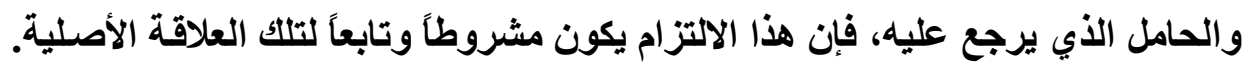

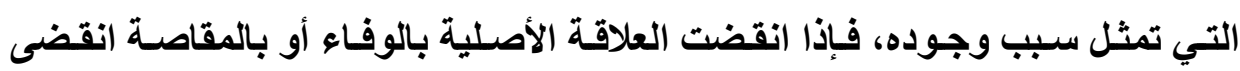

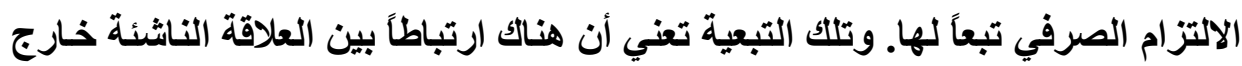

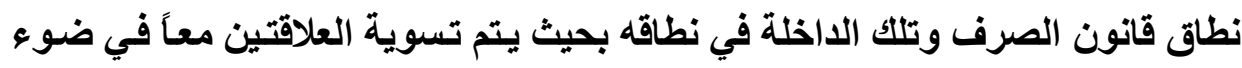

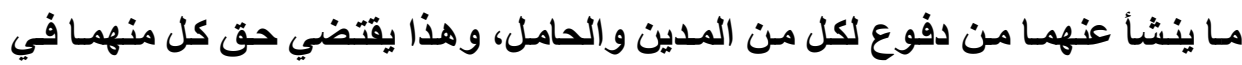

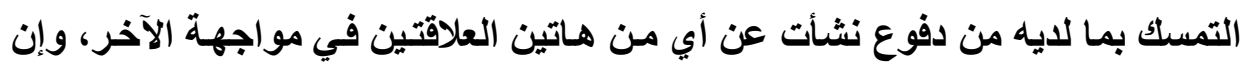

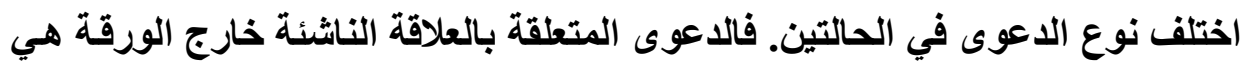




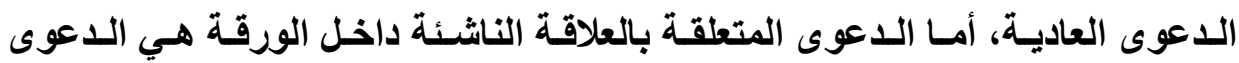
الصرفية.

وكما سبق وذكرنا فإنـه يقصد بالدفوع الشخصية المباشرة تلك الدفوع الناشئة

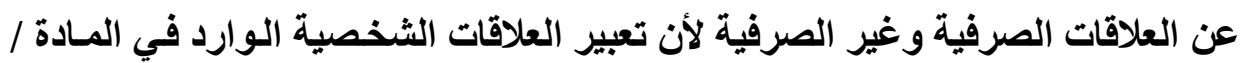

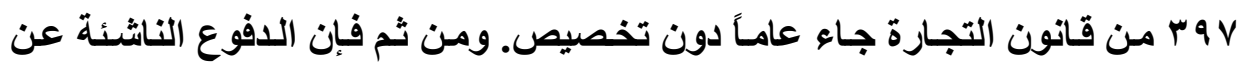
هاتين العلاقتين لا تطهر بالتظهير (')

$$
\text { الاطباب الثاني }
$$

\section{أساس استقلال الالترام الأصلي}

\section{عن الالترام الصرفي}

لقد قيلت عدة نظريـات في تأسـيس الاسـتقلال بين الالتزام الأصـلي والالتزام

الصرفي (الفرع الأول) ولنا في هذا الأساس رأي (الفرع الثاني).

\section{الفرع الأول}

\section{النظريات الفقهية لتأسيس استقلال الالترام الأصلي}

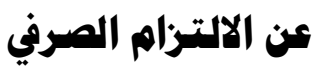

انقسم الشراح في تأسسيس الاسـتقلال بـين الالتز ام الأصـلـي الالتزام الـصرفي

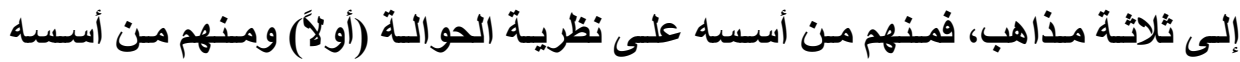
على نظرية الإنابة (ثاتياً) والفريق الثالث أسسه على نظريـة اندماج الحق في الصك 
ذهـب أنـصار هذه النظريـة(') في تعليـل ظـاهرة عدم جـواز الاحتجـاج بالـدفوع والاستقلال بين الالتزام الأصلي والالتزام الصرفي إلى القول بـان إنشاء السند ومـا تهاء

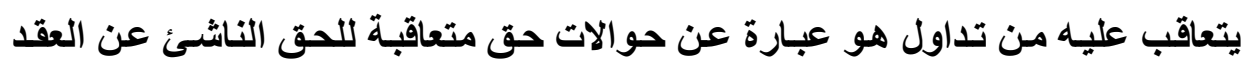

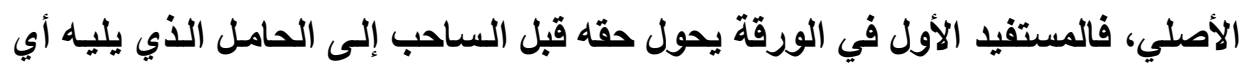
المظهر إليه، ويعتبر كل حامل في الورقة خلفاً للحامل الذي يسبقه في خصوص الأهل هذه

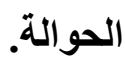

إلا أن تلكك النظرية قد تعرضت لعدة انتقادات كان أهمها أن قواعد الحوالة تقتضي أنـه يجوز للمدين، إذا كاتت لـه دفوع في مواجهة المحيل، أن يـدفع بها في مواجهة المحال إليه. وهكذا تنتهي نظرية الحوالة إلى عكس ما كانت تريد تعليله وهو عدم جواز الاحتجاج بالافوع التي كان يجوز التمسك بها وهابه الحامل السابق.

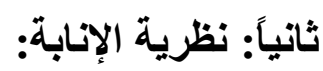

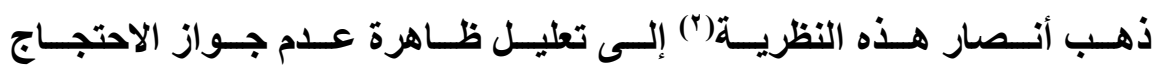
بالدفوع والاستقلال بين الالتزام الأصلي والالتزام الصرفي عن طريث اللجوء إلى فكرة الإنابة.

والإنابـة قانونـاً هـي عمليـة قانونيـة تتضمن اتفـاقين متتـاليين، وثثلاثة أشـخاص، فيبرم الاتفاق الأول بين المنيب والمناب يتعهد بموجبه المناب للمنيب بأن يبرم اتفاقًا مع

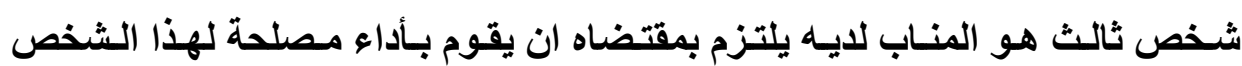

(1) Escarra, manuel de droit commercial T. 2. 1948, p. 676.

(2)Thaller, Nature Juridique du titre de crédit. Ann. Droit commercial 1906. no 60 etss. 
الثالث. أما الاتفاق الثاني فيبرم بين المناب والمناب لايه. وعلى ذلك فإنها يتعين توافر رضا ثلاثة أشخاص هم: المنيب والمناب لديه والمنـاب. وينشأ عن الاتفاق الثاني بين المناب والمناب لايه التزام على عاتق المنـاب في مواجهة المنـاب لديه. ويكون التزام المناب في مواجهة المناب لايه مستقلاً عن التزامه في مواجهة المنيب.

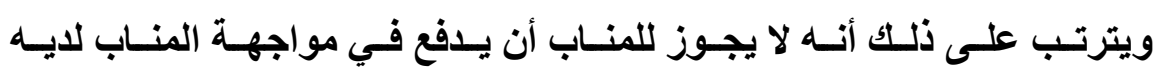
بالدفوع التي كانت لله في مواجهة المنيب بسبب استقلال التزام المنـاب في مواجهة المنيب.

وبتطبيق نظرية الإنابة على الورقة التجارية يكون الساحب عندما يسحب الورقة على مدينه لصالح المستفيد ينيب المدين وهو المسحوب عليه في أن يلتزم في مواجهة المستفيد، وأن المستفيد عندما يظهر الورقة إلى مستفيد آخر فهو ينيب المسحوب عليه

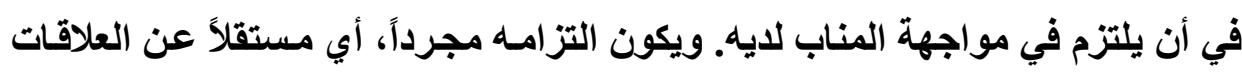
التي تربطه بالساحب.

ولكن هذه النظرية تعرضت لانتقادات كثيرة كسان من أهمها أن من شروط صحة

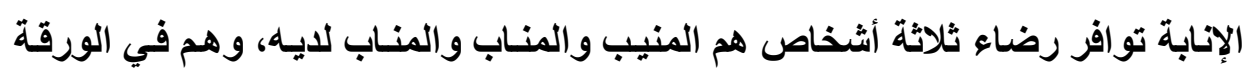
الساحب والمسحوب عليـه والمستفيد، في حين أن رضـاء المسحوب عليهه (المنـاب) وقبوله للورقة ليس شرطاً لنشأتها، فالورقة تكون صحيحة حنى ولو لم يكن عليها قبول

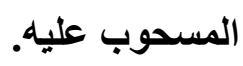
ثالثاً: نظرية اندماج الحق في الصك: ذهب أنصار هذه النظريـة(1)، في تعليل ظـاهرة الاستقلال بين الالتزام الأصلي والالتزام الصرفي وما يتفرع عنها من عدم جواز الاحتجاج بالدفوع على الحامل حسن 
النية، إلى أن تلك الظاهرة تقوم على أساس اندماج الحق في الصك. فالحق وفقاً لهذه

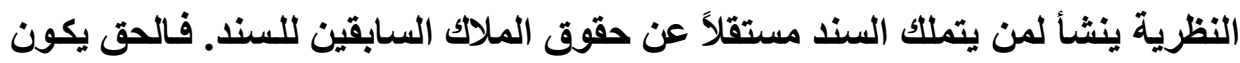
مملوكاً من أول الأمر لثخص غير معين ولكنه قابل للتعيين عن طريق حيازة السند.

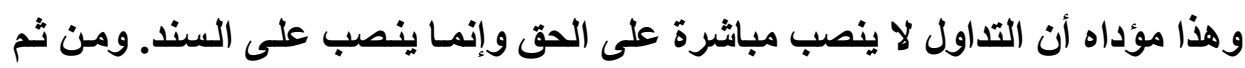

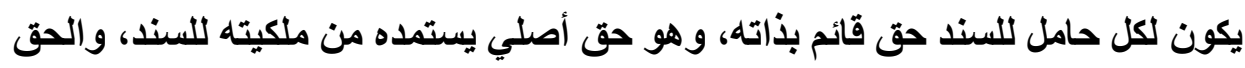
المستقل الناثشئ عن السند يسمى بالحقى الورقي.

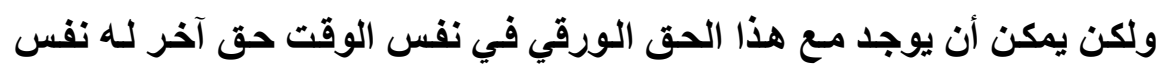

المضمون الاقتصادي، نشأ عن علاقة سـابقة تمت بين الطرفين. وهذا التعاصر بين

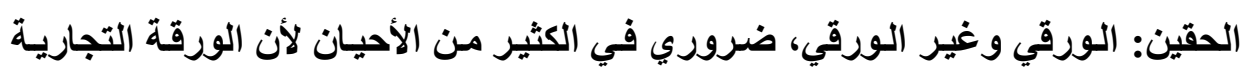

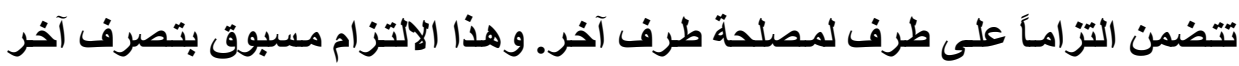

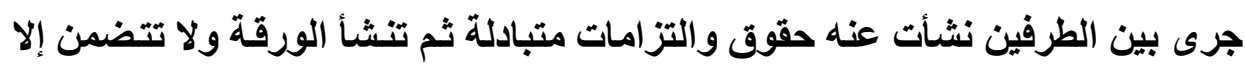

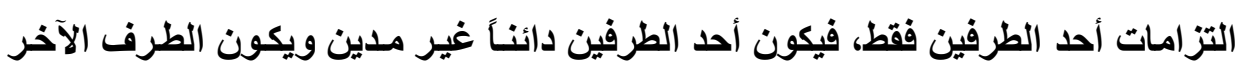

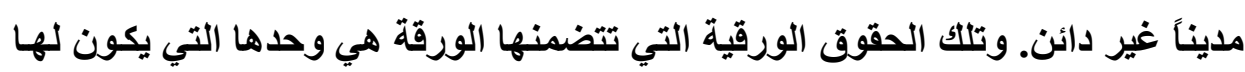

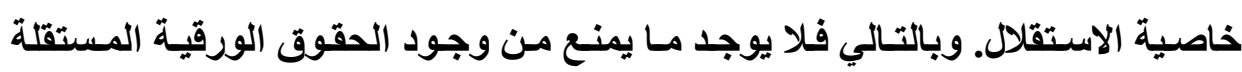

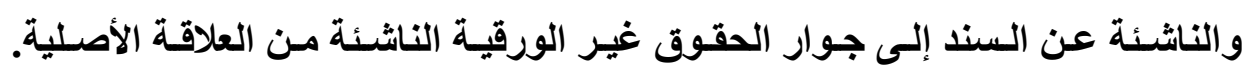

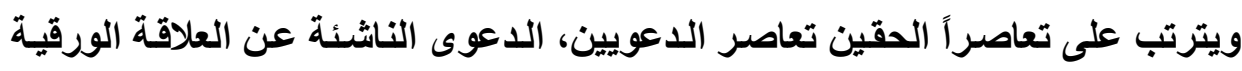
والدعوى الناشئة عن العلاقة غير الورقية، أي العلاقة الأصلية.

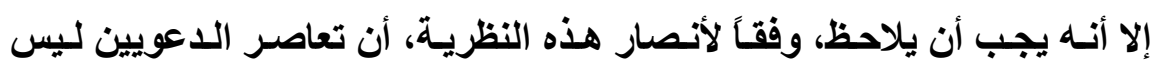

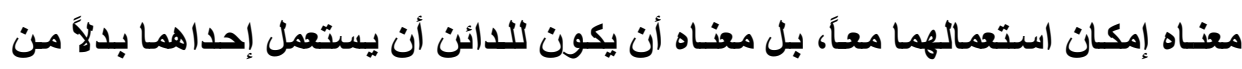

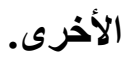




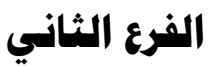 \\ رأينــا الخــاص}

لقد لخص بعض الفقه بشكل رائع وعميق(') نقاط البحث في العلاقة بين الالتزام

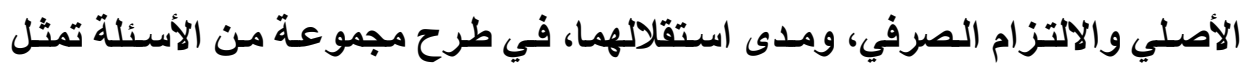

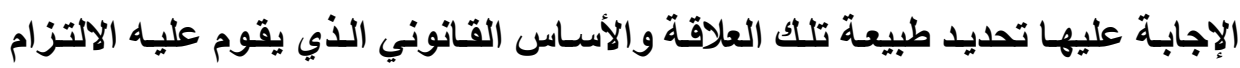

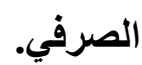

فتساعل الفقهه في هذا الخصوص: هل تمثل العلاقة الصرفية علاقة جديدة

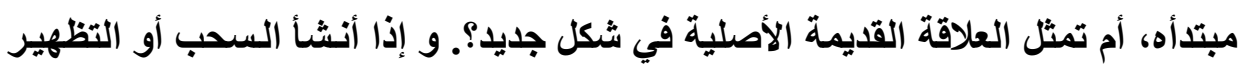

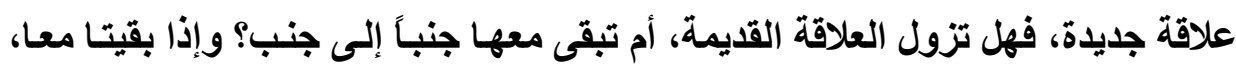

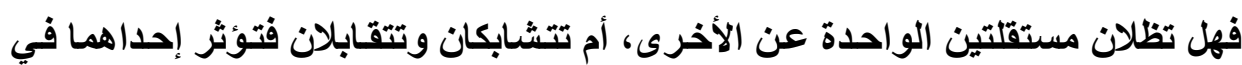
الأخرى؟ - إن

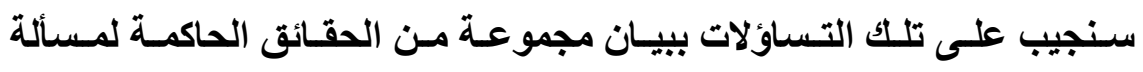

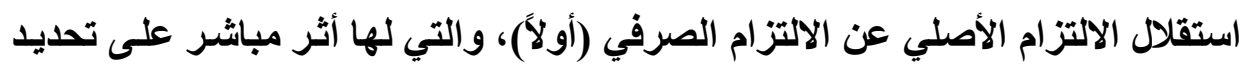
طبيعة الالتزام الصرفي في ضوء استقلاله عن الالتزام الأصلي (ثانياً). أولاً: حقائق حاكمة لمسألة استقلال الالتزام الصرفي عن الالتزام الأصلي: نسرد مجموعة من الحقائق لها أثر مباشر على مسألة استقلال الالتزام الصرفي

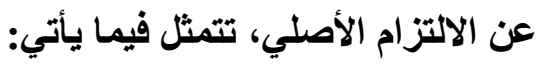

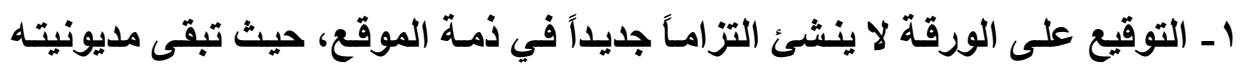

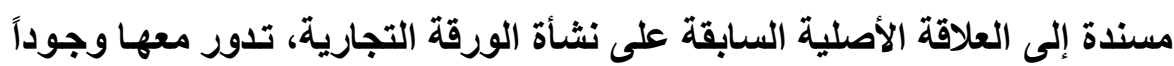


r - أن التوقيع على الورقة التجارية لا يعدل مصدر الالتزام بدفع قيمتها وإنما يعدل فقط

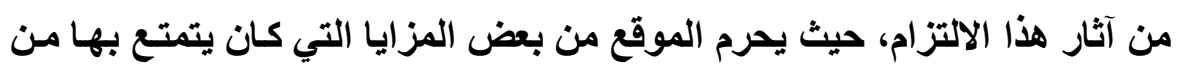

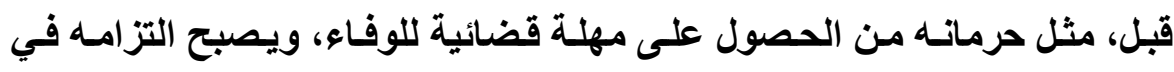

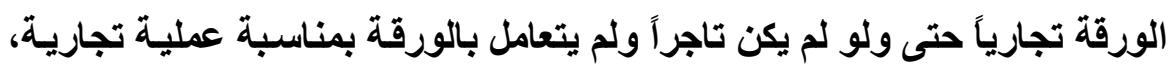

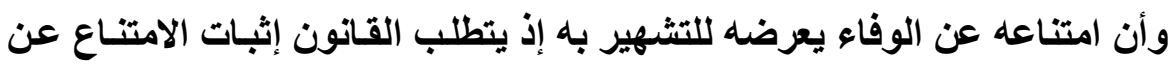

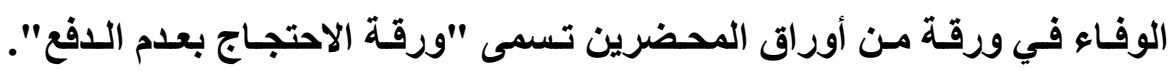

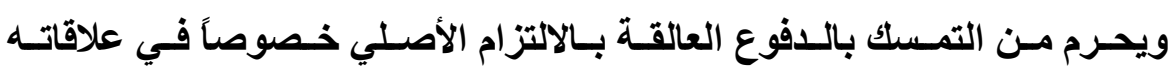
الثخصية والمباشرة مع أصحاب الحق في الورقة التجارية. وغير ذلتك من أحكام

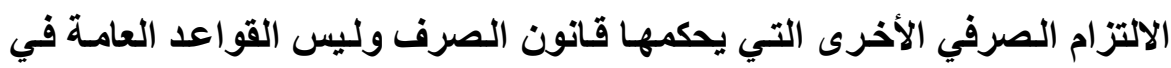

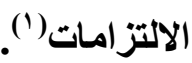

r- لا يعد نشوء الالتزام الـصرفي بتوقيـع الملتزم بـه على الورقـة التجاريـة تجديــاً

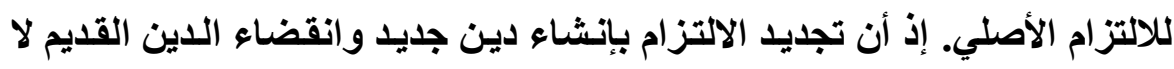

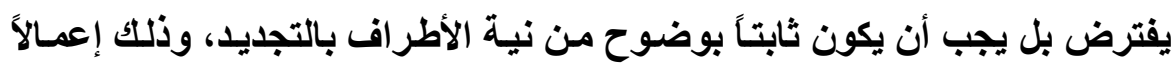

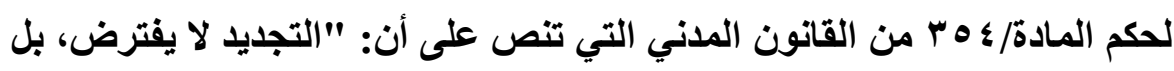
يجب أن يتفق عليه صراحة، أو أن يستخلص بوضوح من الظروف". وقاضسي الموضوع هو الذي يستخلص هذه النية، وهي مسألة موضوعية لا تراقبها محكمة انهية

النقض (r) (الموصوع

(1) Thaller et Percerou, traité élémentaire de droit commercial Paris 1931. t. 2.3 p. 807.

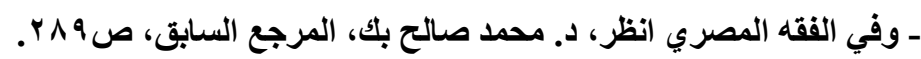

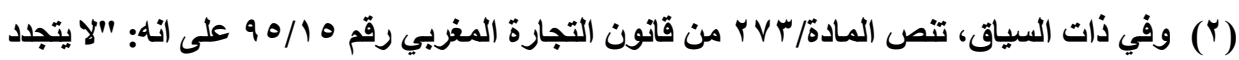

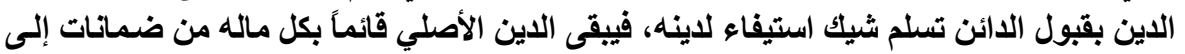


ع ـ أن التوقيع على الورقة التجارية يؤكد التزام الموقع بالوفاء بالالتزام الأصلي الناثئ

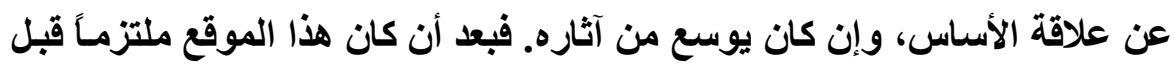
شخص واحل، يصبح مسئولاً في مواجهة كل من تظهر إليه الورقة التجارية.

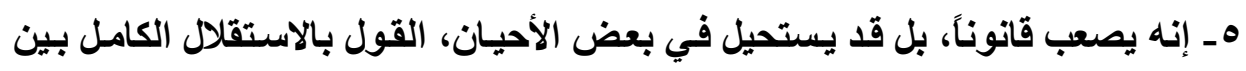

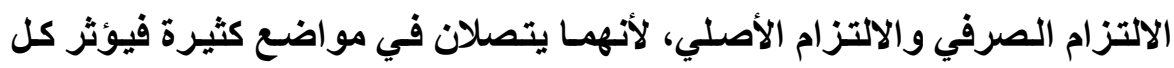

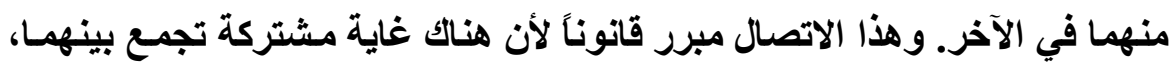

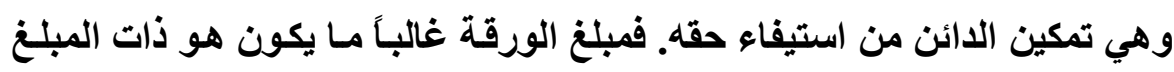

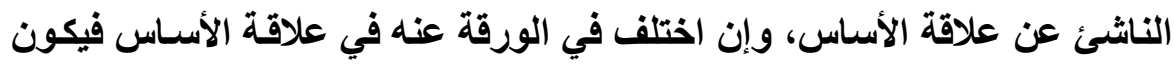

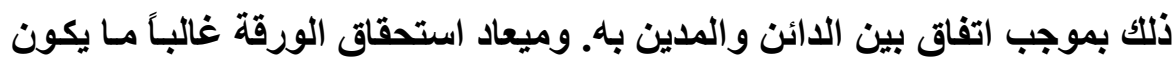

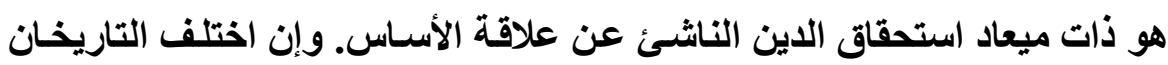
فيكون ذلك باتفاق بين الدائن والمدين.

كما أن الدفوع العالقة بالالتزام الأصلي، وتطبيق قاعدة تطهيرها، التي تعد الحسكم

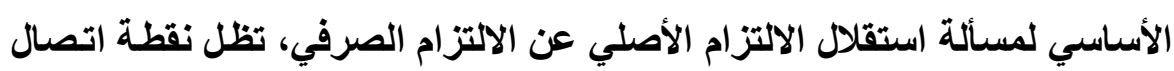

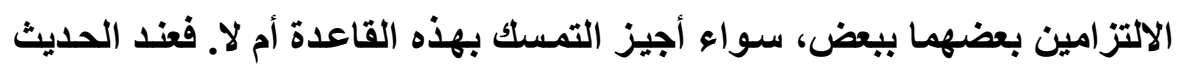

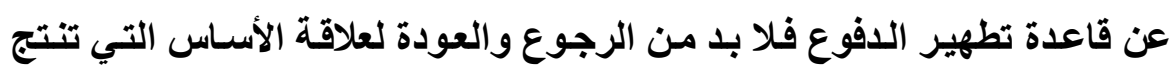
عنها هذه الدفوع.

ج- إن المتعاقدان قد قصدا بتحرير الورقة والتوقيع عليها من قبل المدين إيجاد أداة

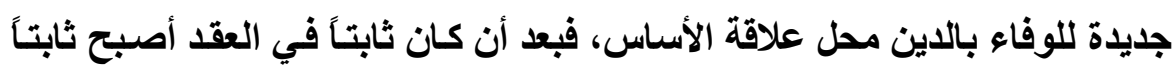

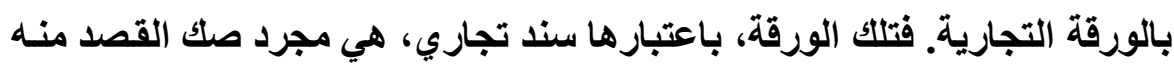

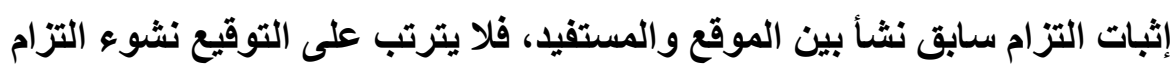

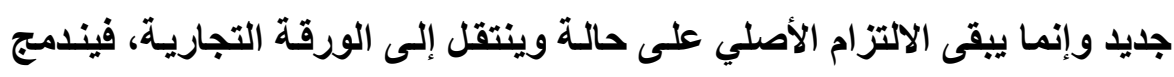

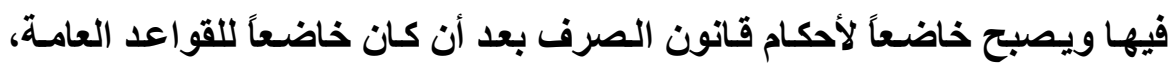


فالأمر في النهاية يتعلق بدين واحد هو الدين الأصلي الذي ارتدى ثوبـاً جديداً هو الورقة التجارية.

وليس هناك ما يمنع قانوناً من أن يلتزم المدين بطريقين مزدوجين للقيـام بـالتزام

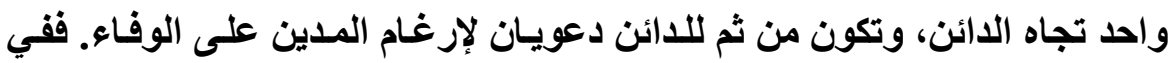

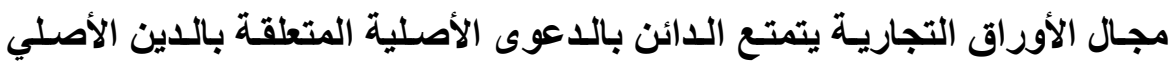

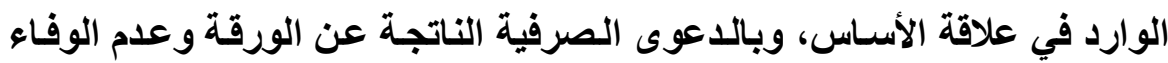

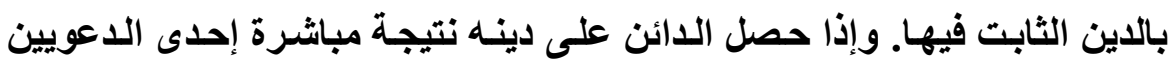

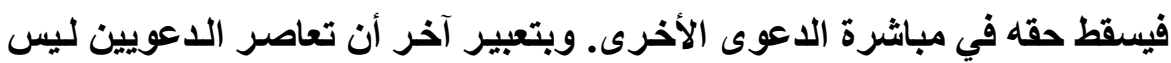

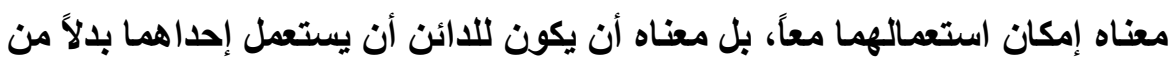
الأخرى، فله أن يستعمل إحدى الدعويين عند عدم إمكان استعمال الدعوى الأخرى

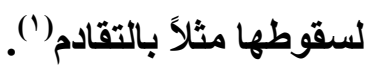

V- إذا كانت العلاقة السابقة على نشأة الورقة التجاريـة يتضمنها عقد الأسـاس الذي

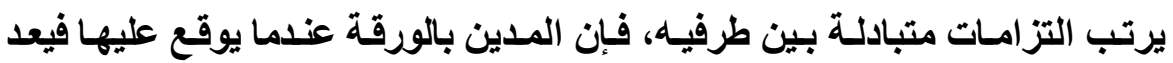
توقيعه بمثابة إقراراً منه بصحة الدين الناشئ عن علاقة الأسـاس، وإقرار بالتزامسه

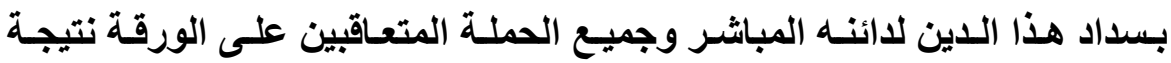
تظهيرها. والمدين قد تنازل بموجب هذا الإقرار عن التمسك بالدفوع الناشئة عن الدين في مواجهة دائنه المباثر وفي مواجهة كل من تربطه بهم علاقة مباته مباشرة

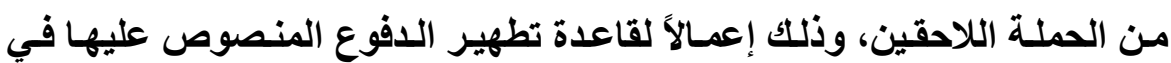

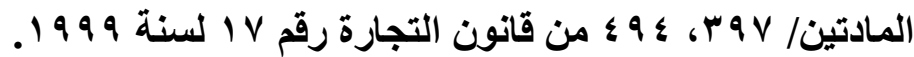
فيترتب على توقيع المدين على الورقة ـ كما ذكرنا ــ أن الدين بعد أن كـان ثابتاً

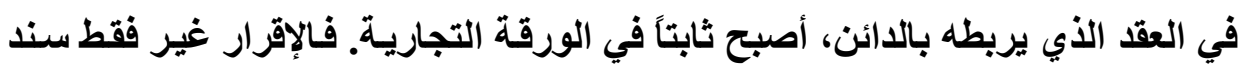


ومن خلال مجموعة المعطيات سالفة الأكر، يمكن التوصل إلى النتائج الآتية: ا - أن تحرير الورقة التجارية والتوقيع عليها ليس تجديداً للالتزام الناثئ من علاقة

الأسناس.

r ـ أن توقيع المدين على الورقة يضيف على عاتقه التزامـاً آخر، يضـف لالتزامسه السابق الثابت في عقد علاقة الأساس، بسداد ذات الدين. فهناك التزامان يتعلقان

بسداد دين واحد. ولكل منهما دعوى مستقلة تحميه.

rـ أنه لا يمكن قانونـاً الحديث عن الاستقلال الكامل بين الالتزام الأصلـي والالتزام

الـصرفي. ففي ضـوء الـص صـراحة على قاعدة تطهير الـدفوع في قـانون

التجارة، فإن الربط بين الالتزامين حتمي، حيث لا يجوز الحديث عن تلك القاعدة

وآثارها إلا بـالربط بين هذين الالتزامين، إذ أن هذا الربط هو الذي يؤدي إلى

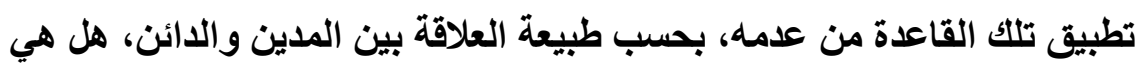
علاقة شخصية مباشرة أم لا، وبحسب حسن أو سوع نية الحامل (1) ف ففي حالة العلاقات المباشرة، وفي حالة سوء نية الحامل، تتعطل آثار تلك القاعدة.

ــ أنه لا يمكن القول بأن الالتزام الصرفي مجرد عن سببه، لأن كل التزام يجب أن

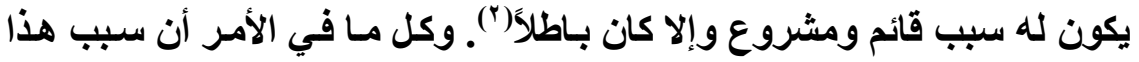
الالتزام ومشروعيته مفترضسان، أي أن هذا السبب مفترض وجوده ومفترض

مشروعيته، وعلى من ياعي عكس ذلك أن يثبته.

(1) حول سوء أو حسن نية الحامل، انظر تفصيلاً د. رضـا السيد، د. حسام رضا، الأوراق التجاريـة،

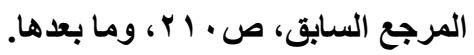

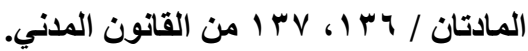


هـ أن التعامل مع الورقة التجارية وهي في مرحلة سكون، أي قبل تداولها، يختلف

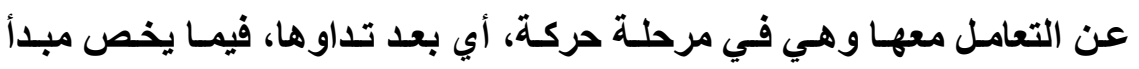

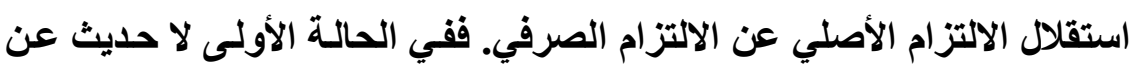

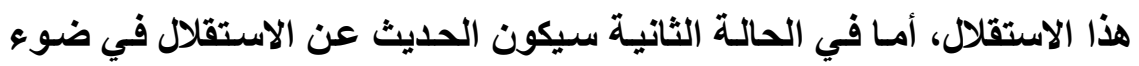
أحكام قاعدة تطهير الافوع والآثار المترتبة عليها. ثانياً: الطبيعة القانونية للالتزام الصرفي في ضوء استقلاله عن علاقة الأساس: لقد ثار خلاف في الفقه حول الطبيعة القانونيـة للالتزام الصرفي، هل هو التزام

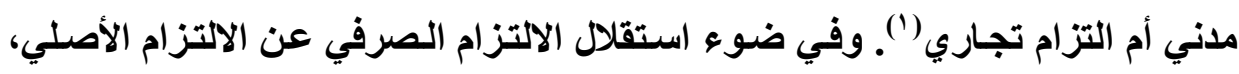

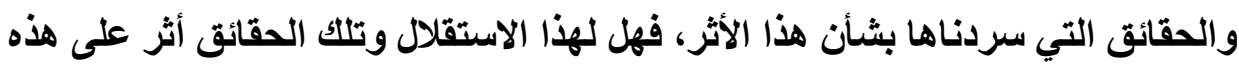

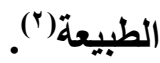
(1) الخلاف الفقهي حول مدى تجارية الالتزام الصرفي وموقف محكمة النقض في هذا

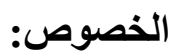

تـــازع الفقـهـ المصري اتجاهـان بشأن الطبيعة القانونيـة للالتز ام الصرفي (أ)، وأصدرت محكمة النقض المصرية حكماً في هذا الخصوص حسمت بـه الخلاف الفقهي (بذانكور (ب).

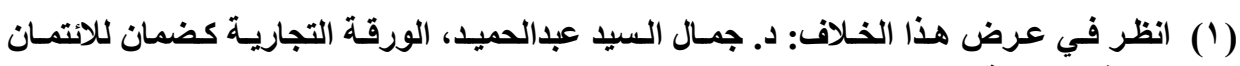

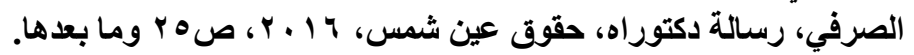

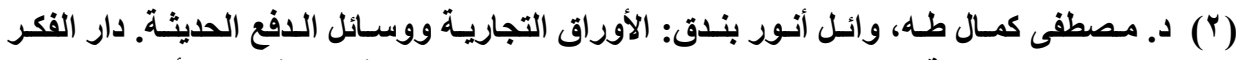

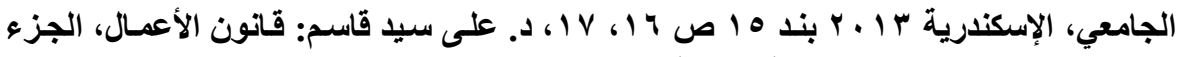

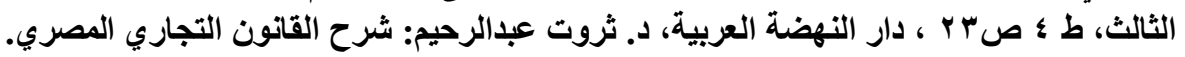

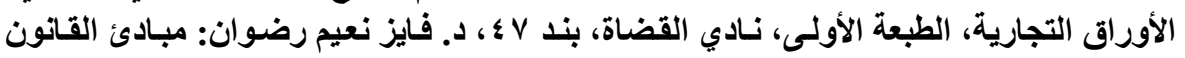

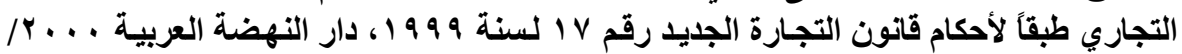

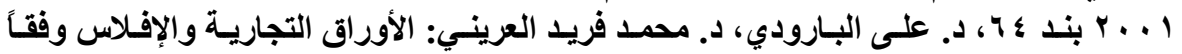

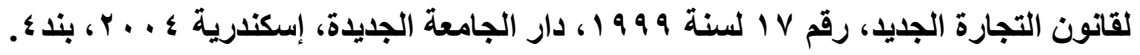


انقسم الفقه المصري حول الطبيعة القانونية للالتزام الصرفي، هل هو ذو طبيعة

تجارية بطبيعته أم أنه عمل تجاري بالتبعية( )

الاتجاه الأول:

ذهب أنصار هذا الاتجاه إلى أن الالتزام الصرفي هو عمل تجاري مطلقاً مستندين

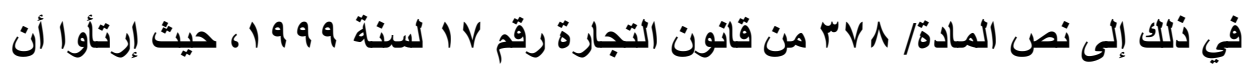
هذا النص كـان صريحاً في اعتبار الأوراق التجاريـة عملاً تجاريـاً مطلقاً إذ تنص تلتك

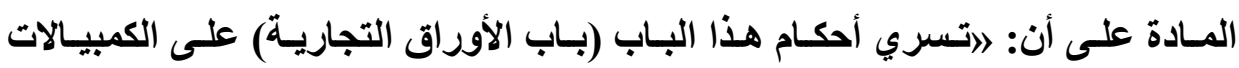

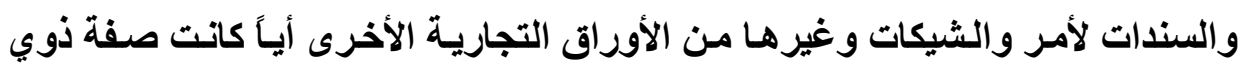

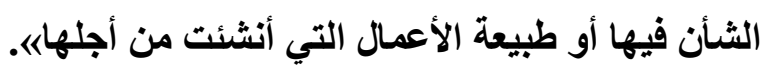

ووفقاً لأنصار هذا الرأي فإن الالتزام الصرفي يعد عملاً تجاريـاً مطلقاً أياً كانت صفة

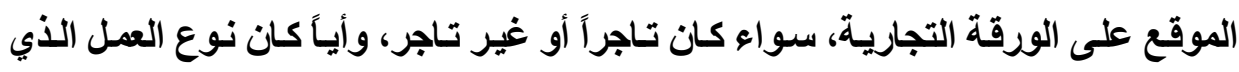
تحررث الورقة بمناسبتهه، مدنياً أو تجارياً. وأضاف أنصار هذا الاتجاه إلى أن الالتزام الصرفي هو عمل تجاري شكلي، أي

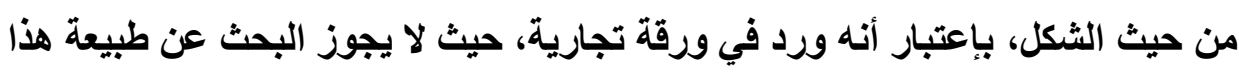
الالتزام خارج الورقة التجارية لتمتعها بمبدأ الكفاية الأتية. ويعلل جانب من الفقه(') خلع الصفة التجارية المطلقة على الأوراق التجارية بأن الورقة التجارية تتثاول وتتتقل من يـ لأخرى، ولا يـري حاملها مـا هي طبيعة الدين

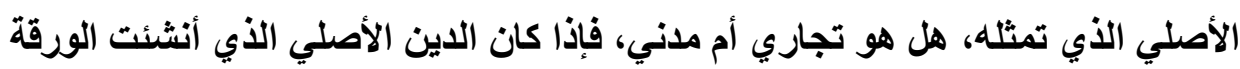
(1) د. مصطفى كمال طه، وائل بندق، الأوراق التجارية ووسائل الدفع الحديثة، مرجع سابق، بند V إ، ص 11 د. 
التجارية من أجله تجارياً، فقد تظهر فيمـا بعد ذات الورقة التجاريـة وفاء للدين مدين،

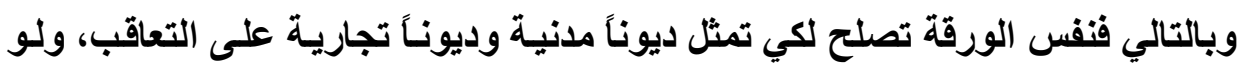
اعتبرت الورقة تجارية تارة ومدنية تارة أخرى تبعاً لصفة الدين الذي تسحب أولئ أو تظهر وفـاء لـه، لأدى ذلـك إلى صـعوبات عمليـة كبرى، وخـصوصاً فيمـا يتعلـق بالأهليـة

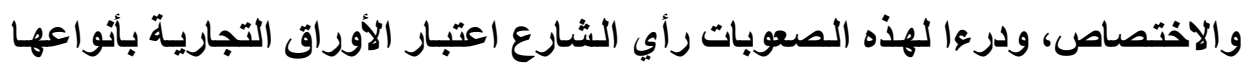

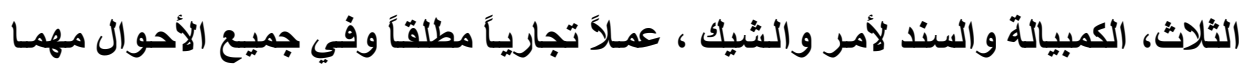

يكن سبيه أو صفة الموقع على الورقة التجارية. : (1)

يرى أنصار هذا الاتجـاه أن المشرع قد عـالج في قانون التجارة مسألة اعتبار

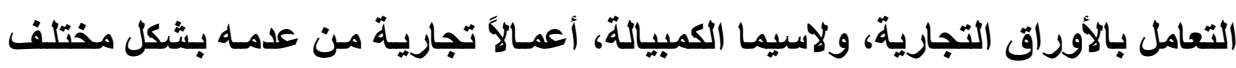
عن قانون التجارة الملغي. فكاتت تنص المادة/ץ من هذا القانون الملفي على أن: إيعتبر بحسب القانون عمـلاً تجارياً كل عمل متعلق بالكمبيـالات أيـاً كـان أولى الشأن فيهی).

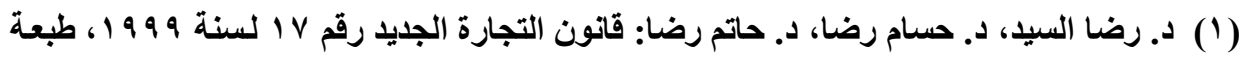

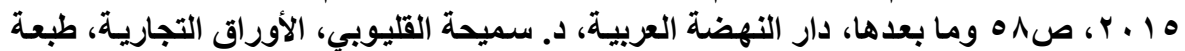

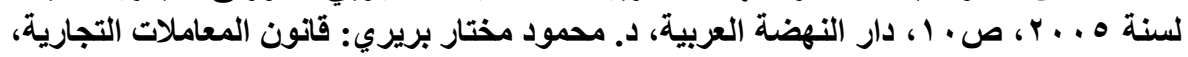

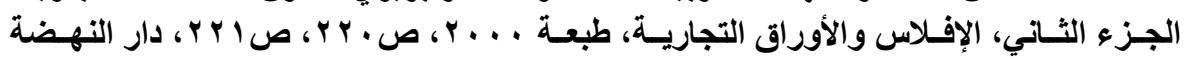

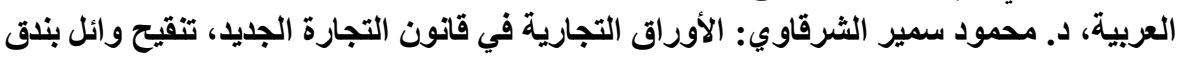

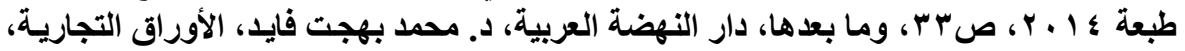

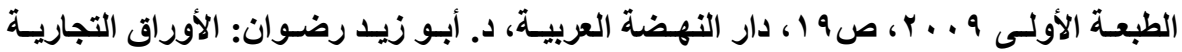

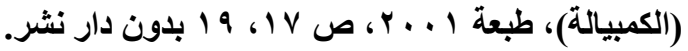


فالمشرع، بهذا النص، قد اعتبر أن جميع التعاملات الخاصة بالكمبيالة، كسحبها

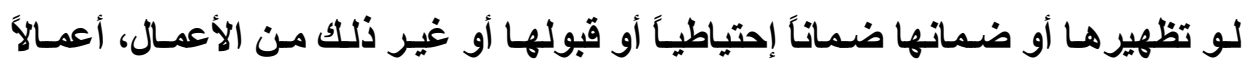
تجاريـة بطبيعتها أي بنص القانون، بصرف النظر عن صفة التعامل بها سواءواء أكسان تاجراً أو غير تاجر، وبصرف النظر عن طبيعة العملية التي حررت بمناسبتها سواء أكاتت عملية مدنية أو تجارية.

وكان المشرع في القانون الملفي يعتبر الأعمال المتعلقة بالكمبيالة أعمالاً تجارية على سبيل المقاولة وليس أعمالاً تجاريـة منفردة، بحيث لا تضفي عليها هذه الصفة

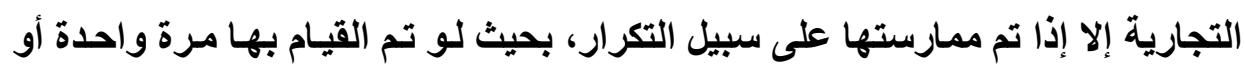

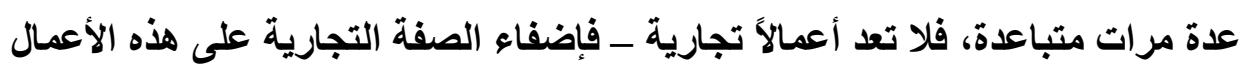

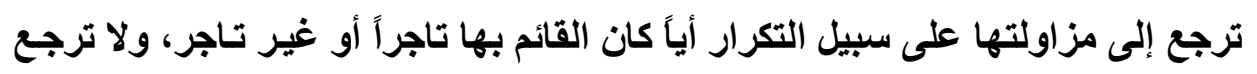

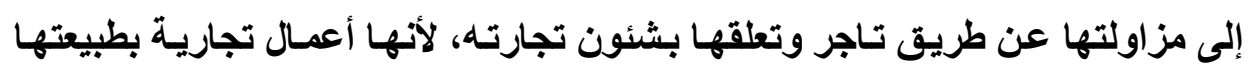

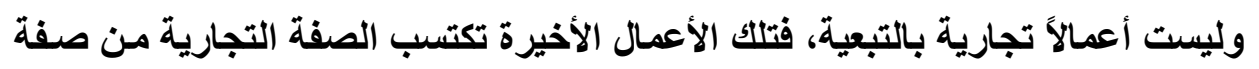

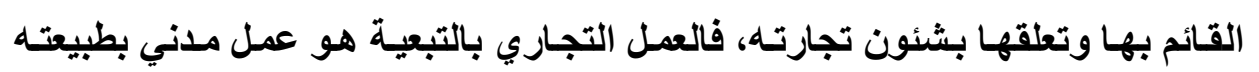

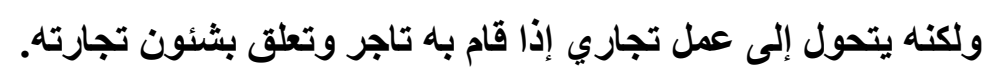

وعلى ذلك فإن الأعمال التجارية بالتبعية لا تضفي على القائم بها صفة التاجر، فالعكس هو الصحيح، إذ أن التاجر هو الأي يسبغ على تلك الأعمـال الصفة التجاريـة،

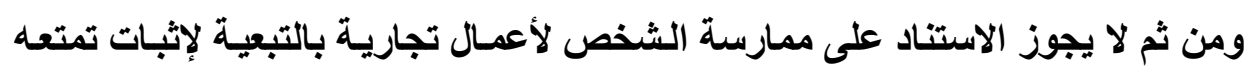

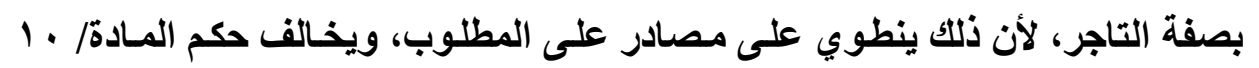
فقرة (1) من قانون التجارة الحسالي التي تنص على أن التاجر هو من يحترف العمل هل التجاري، والمقصود هنا العمل التجاري بطبيعته.

أما قانون التجارة الجديد فقد سلك نهجاً مغايراً عن القـانون الملفي بشأن طبيعة

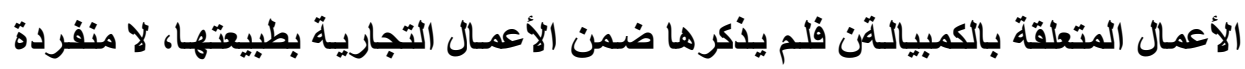


ولا على سبيل المقاولة، حيث جـاء نص المـادة/ ؛ من القـانون المذكور، والذي يحدد

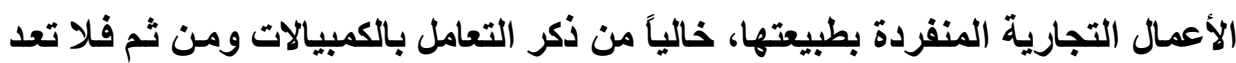

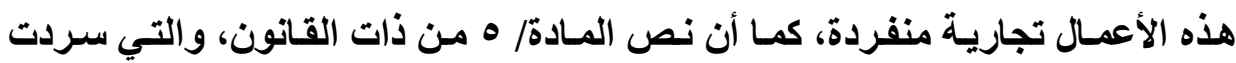
الأعمال التجارية بطبيعتها على سبيل المقاولة، قد جاعت خالية أيضاً من ذكر الكمبيالة، فهل هـذا يعنـي أن التعامـل بالكمبيالـة في قـانون التجـارة الحسالي ليس عمـلاً تجاريـاً

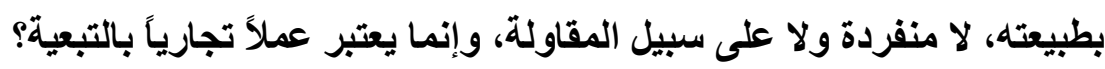
نحن نرى أن قانون التجارة الحالي قد سوى بين الشيك والسند الأذني من جهة

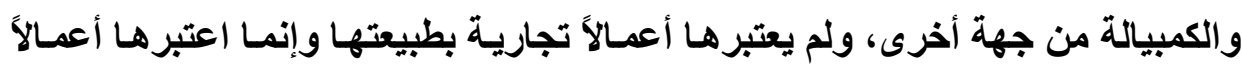

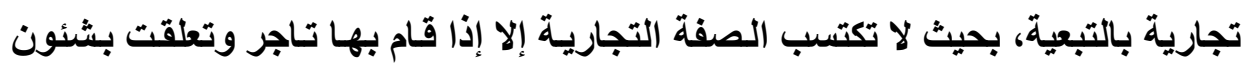

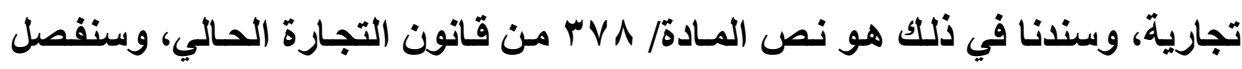
حكم هذه المادة على النحو التالي: * المادة/ HVA من قانون التجارة الحالى: تنص المادة rv من قانون التجارة الحالي على أن: |اتسري أحكام هذا الباب على الكمبيالات والسندات لأمر والشيكات وغيرهـا من

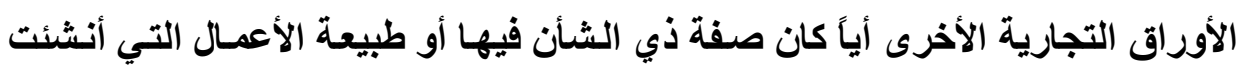
من أجلهای. ويقصد بعبـارة "هـذا البـاب" الـواردة بـالنص المـذكور البـاب الرابـع الخـاص بالأوراق التجارية، ويقصد بأحكامه تلك الأحكام المتعلقة بالالتزام الصرفي الذي تنطوي

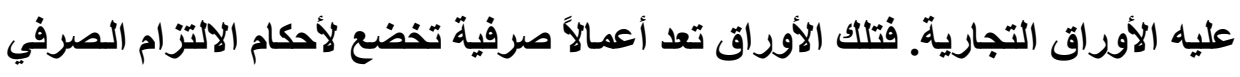
المتمثلة في تضامن الموقعين على الورقة وتطبيق قاعدة تطهير الدفوع والتظهير والضمان الاحتياطي والتقادم وغيرها من الأحكام الواردة في الباب الرابع المشار إليه. 
وتجدر الإثـارة إلى أنـه يجب عدم الخلط بين العمل الصرفي والعدل التجاري،

فمعيار تمييز كل منهما مختلف عن معيار تمييز الآخر، فالعمل المصرفي هو كل عمل الإنس

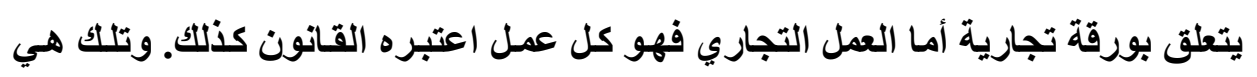
الأعمال التجارية بطبيعتها أو قام بها تاجر وتعلقت بشئون تجارته، وتلكك هي الأعمـال

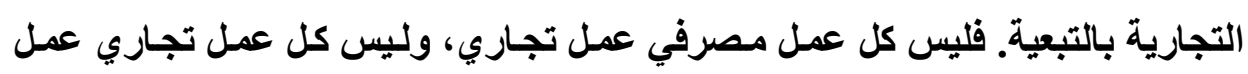

هذا وقد قرر المشرع في المـادة/ rv المشار إليها أن أحكام الالتزام الصرفي

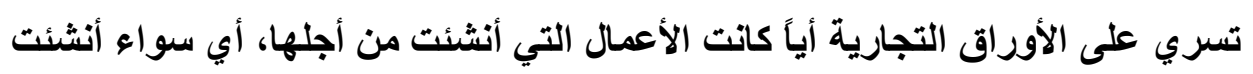

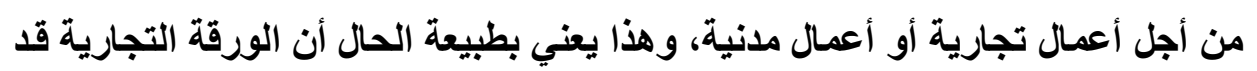

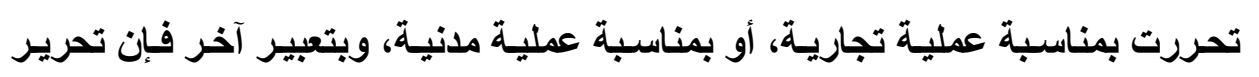

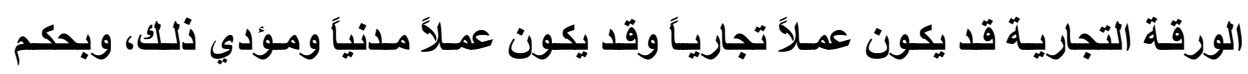

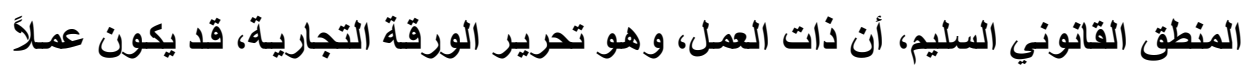

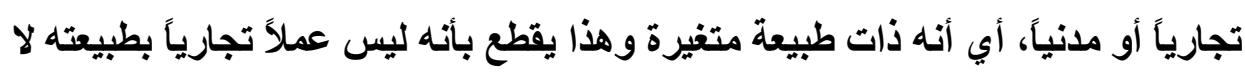

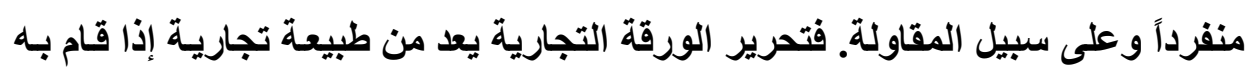

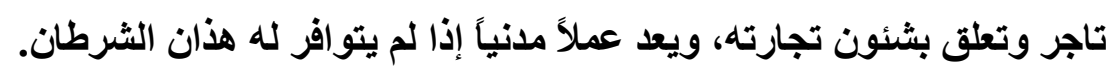

ومـؤدي ذلكـ كلـه أن تحريـر الورقـة التجاريـة يعد عمـلاً تجاريـاً بالتبعيـة وليس

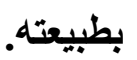

** موقف المذكرة الإيضاحية لقانون التجارة الحالى:

لقد جاء بالمذكرة الإيضاحية ما نصه:

\أخضع المشرع الأوراق التجارية لأحكام قانون الصرف بغض النظر عن صفة الموقعين عليها أو طبيعة العلاقات التي حررت الورقة من أجلهاب. 
فالمذكرة الإيضاحية عندما ذكرت عبارة ابصرف النظر عن طبيعة العلاقات التي حررت الورقة مـن أجلهاء، قـ أكدت مـا سـبق وذكرنـاه مـن حيث أن طبيعة الأعمـال

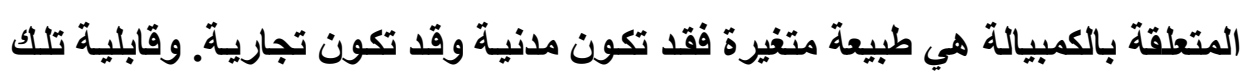
الطبيعة للتغيير لأبلغ دليل على أن هذه الأعمال ليست أعمال تجاريـة بطبيعتها ولكنها

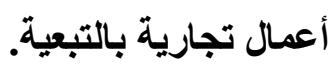
(ب) موقف محكمة النقض: لقد قضت محكمة النقض في حكمها الصادر بجلسة ه // / ب . . r في الطعن رقم هـ لسنة • Vاق (هيئة عامة) بأنه: اوكـان الحكم المطعون فيـه قد استلال على توافر صفة التاجر في الطـاعن من تحريره للكمبيـالات المستحق قيمتها للمطعون ضـده الأول والتي توقف عن سـادها واستخلص بما أثبت بها من أن القيمة وصلت بضاعة أن تحريرها كان بمناسبة عمليات تجاريـة، هـو مـا يكفي لحمل قضاء الحكم بتـوافر هذه الصفة فبإن النعي على الحكم

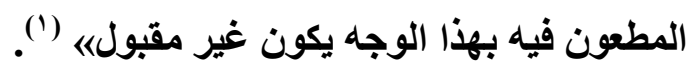

يتضح من هذا الحكم أن محكمة النقض قد اعتبرت الأعمـال التجاريـة المتعلقة بالكمبيالة أعمالاً تجارية بالتبعية، ورغم ذلك فقد جعلتها سبباً لإسباغ صفة التـاجر على التى من يتعامل بها، في حين أن التاجر هو الذي يضفي الصفة التجاريـة على تلك الأعمـال

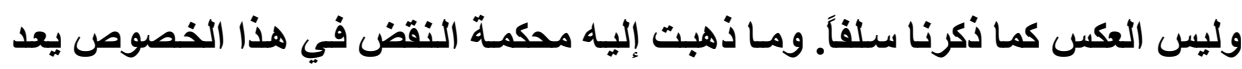
مصادرة على المطلوب. 
(r) أثر استقلال الالتزام الصرفي عن علاقة الأساس على طبيعته القانونية: بداءة نشير إلى أننا نؤيد الاتجاه الثاني وما ذهبت إليه محكمة النقض الذي يرى أن الالتزام الصرفي هو عمل تجاري بالتبعية. وهذا التكييف يتفق مع استقلال الالتزام الصرفي عن علاقة الأساس. فالورقة التجارية عندما تكون في حالة سكون سينظر إلى طبيعة الالتزام الصرفي من منظور طبيعة الدين الوارد في علاقة الأسـاس لارتباط تلكك العلاقة في هذه الفترة، وهي فترة السكون أي قيل تظهيرهـا، بـالالتزام الصرفي وعدم الصن استقلالها عنه، أما إذا تحركت الورقة التجاريـة بتظهيرهـا، فتنشأ علاقة أسـاس جديدة بين المظهر والمظهر إليه، وينظر لطبيعة الالتزام فيها من منظور تلكك العلاقة.

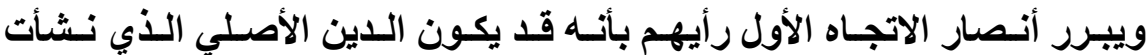
الكمبيالة لتسويته ديناً تجارياً، ثم تظهر بعد ذلك وفاء لدين مدني، فالورقة الواحدة هنـا تمثل دين تجاري ودين مدني على التعاقب، أي أن التعامل بها يكون تـارة عملاً تجارياً وتارة أخرى يكون مدنياً، وهذا يؤدي إلى صعوبات عملية خصوصاً فيما يتعلق بالأهلية

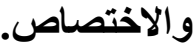

ورداً على هذا التبرير نقول أن اختلاف طبيعة الدين الذي تسحب أو تظهر الورقة سداداً له، هو أمر يمليه مبدأ الاستقلال بين العلاقة التي تربط الساحب والمستفيد، وتلكت التي تربط المظهر بالمظهر إليه وكذلك مبدأ استقلال التوقيعات. وهذا الاستقلال الذي لـوني يؤدي لتغيير في طبيعة الدين، يؤدي أيضاً وبالتبعيـة إلى التغيير في طبيعة الالتزام الصرفي، حيث يكون التعامل بالورقة تجارياً إذا كان الدين تجارياً ومدنياً إذا كان الدين مدنياً، فالطبيعة سنتغير بحسب نوع الدين الذي يلتزم بدفعه المدين الذي تم الرجوع

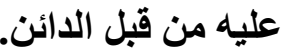
وعلى ذلك فإن القول بأن الالتزام الصرفي هو عمل تجاري بالتبعية لصفة المدين به هو الذي يتفق مع مبدأ الاستقلال بين علاقات الورقة التجارية. ولا مجال هنا للحديث 
عن عدم الاستقلال، لأننا ذكرنا سلفاً أن عدم الاستقلال يثور عند تطبيق قاعدة تظهير الدفوع، أما طبيعة الالتزام الصرفي فلا يمثل دفعاً عالقاً بالورقة التجارية.

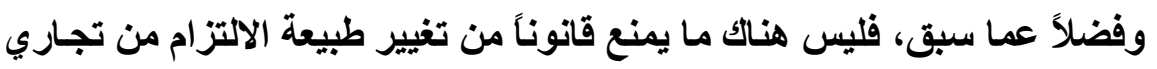

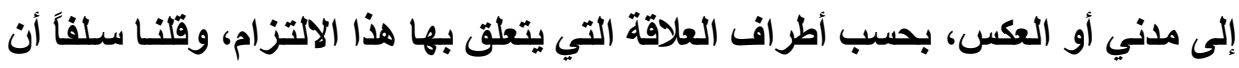

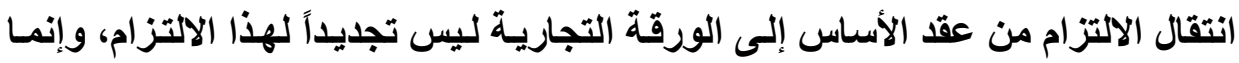

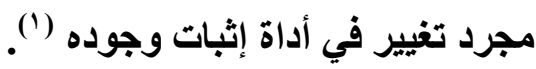




\section{|لفنصل الثانى}

\section{الاستقلال بين العلاقات في هجال الشركات التجارية}

تعتبر الثركة شخصاً اعتباريكا(')، ويختلف تاريخ بدء (كتساب الشركة للشخصية المعنوية بـاختلاف نوع وشكل الشركة (†)، ويترتب على اكتساب الشركة للشخصية

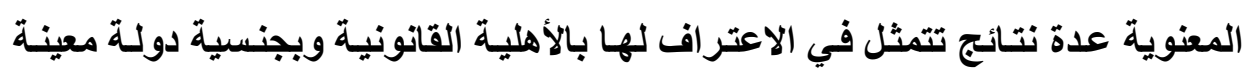
وبموطن يتم مخاطبتها فيه وبالتمثيل القانوني أمام القضاء والغير وتمتعها بذمة مالية

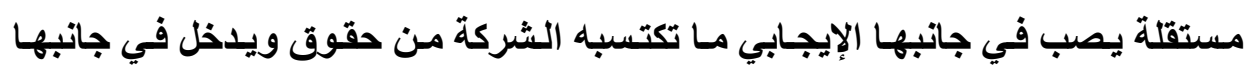

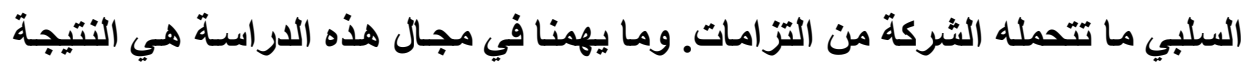

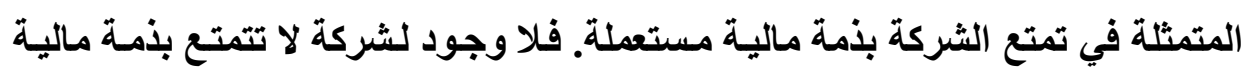

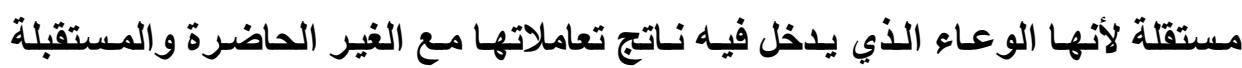

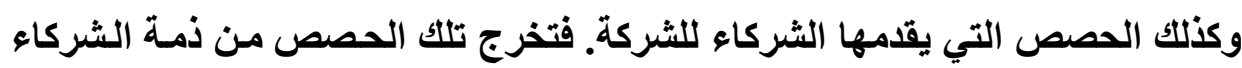

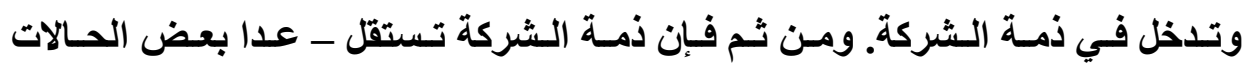
الاستثنائية - عن ذمم الثركاء فيها (المبحث الأول).

وقد ترتبط الشركة بشركات أخرى، ويكونون فيما بينهم مـا يسمى "بمجموعة

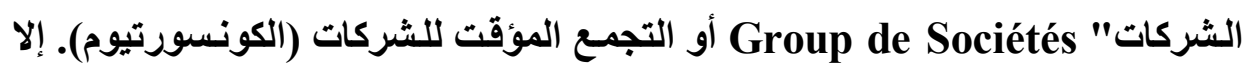

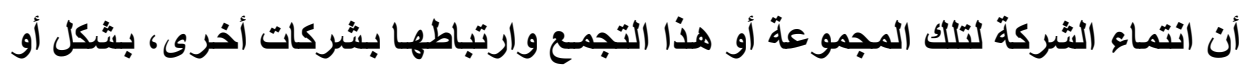
بآخر، لا يؤثر من حيث المبدأ على استقلال الذمم المالية لهذه الثركات المرتبطة لأن كل منها يتمتع بثخصية معنوية مستقلة عن الأخرى (المبحث الثاني). 


\section{المبحث الأول}

\section{استقلال الذهة المالية للشركة عن الذهم المالية للشركاء فيها}

يترتب على اعتبار الشركة شخصاً معنوياً وتمتعها بذمة مالية مستقلة كإحدى

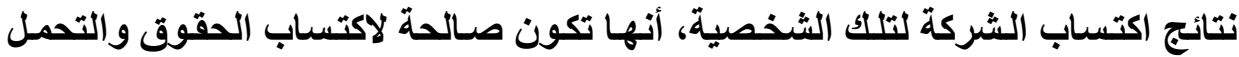

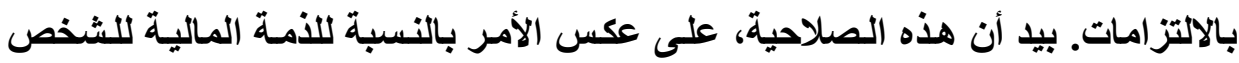

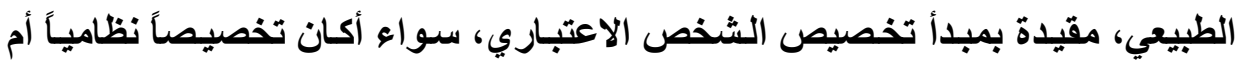

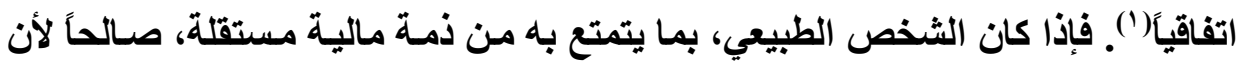
يكون صاحباً للحقوق والالتزامـات بوجه عام ودون تحديد، إذ أن كل الأغراض مباحة

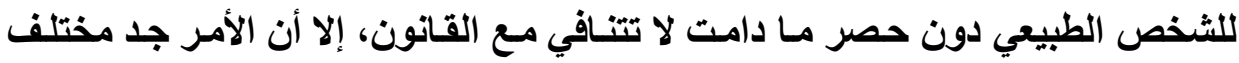

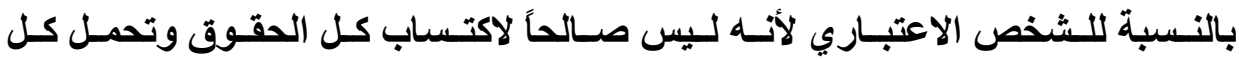
الالتزامات. فتلكك الصلاحية مقيدة ومحصورة في نطاق محدد، وهو نطاق الغرض الذي الذي

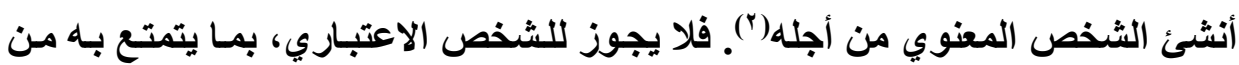

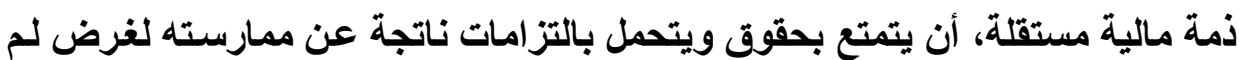

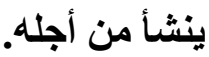

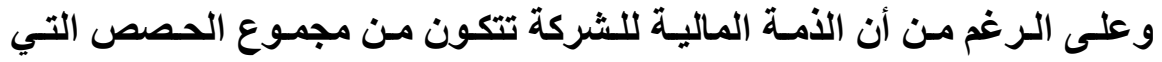

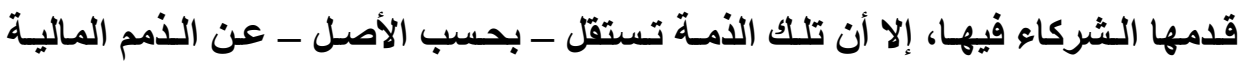
للشركاء فيها (المطلب الأول)، إلا هذا الأصل ترد عليه بعض الاستثناءات (المطلب 


\section{المطلب الأول \\ مبدأ استقلال الذهمة المالية للاشركة \\ عن الذهم المالية لاشركاء}

هناك عدة شروط يجب توافرهـا لتتمتع الشركة بذمسة ماليـة مستقلة ومـا تحتويها تلك الأمة من مكونات (الفرع الأول). وبتوافر هذه الثروط تثبث للشركة الأمسة المالية المستقلة عن ذمم الشركاء فيها، وتحدد تلك الشروط مظاهر هذا الاستقلال ونتائجه (الفرع الثاني).

\section{الفرع الأول}

\section{شروط اكتساب الشركة للذهة المالية وهكوناتها}

أوضـحت المسادة/ به مسن القـانون المـدني الشروط الواجب توافرهـا للاعتراف

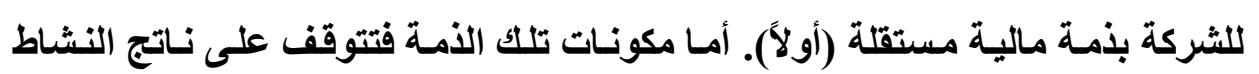
الأي تمارسه (ثانياً).

أولاً: شروط الاعتر اف للشركة باللمة المالية:

للشركة ذمة مالية واحدة، تتكون من عنصرين، عنصر إيجابي ويتضمن الحقوق

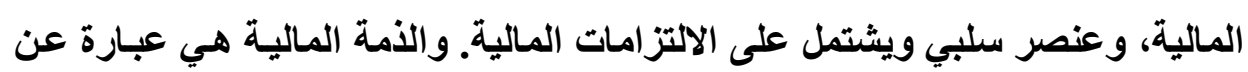

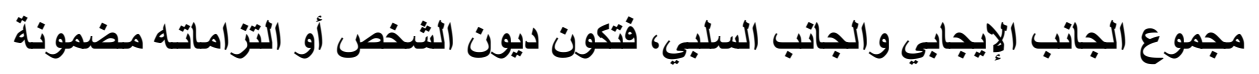

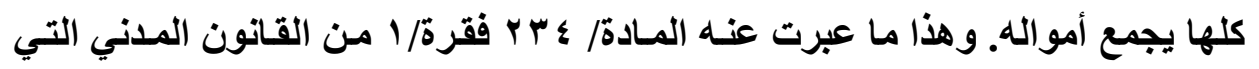
تنص على أن: „| ـ أموال المدين جميعها ضامنة للوفاء بديونها».

ولمـا كانـت الشركة عبـارة عن مجموع مسن الأمسوال تهدف إلى تحقيق عرض معين، فبإن ذلك يتطلب تـخل القانون للاعتراف للشركة بالذمـة الماليـة بالقدر الـلازم 
لتحقيق غرضها. ومن ثم فإن الثروط الواجب توافرها للاعتر اف للشركة بالأمة المالية المستقلة تتمثل فيما يأتي:

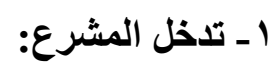
نظراً لاختّلاف طبيعة الشخص المعنوي عن طبيعة الإنسان، فليس لـه وجود حقيقي وليست له إرادة، فإن الاعتر اف له بالثخصية المعنويـة وبالتـالي بالأمسة المالية

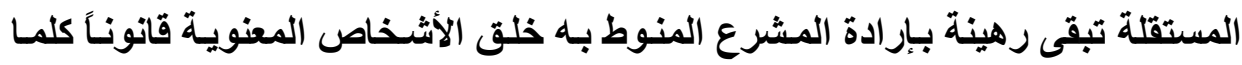
تطلبت الحاجة ذلك. ومن ثم فإن الثخص المعنوي لا يمكن أن ينشا إلا بمشيئة المشرع.

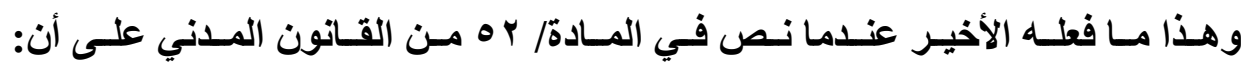

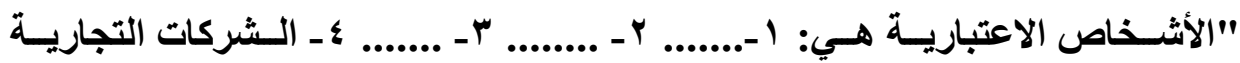
والمدنية". وكذلك عندما نص في المادة/ به من ذات القانون والتي يجر ي نصها على التى

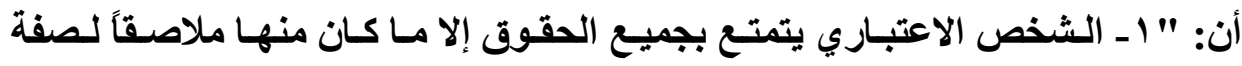

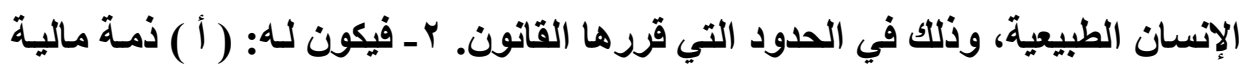

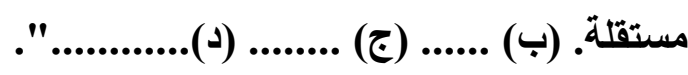

فتلذخل المشرع بهذين النصين قد اعترف للشركة بالشخصية المعنويـة وبالذمـة المالية المستقلة. فالنصان المذكوران هما اللذان أنشأ الثركة كشخص معنوي وأقر بأن لها ذمة مالية مستقلة. ץ ـ قيد الشركة في السجل التجاري:

يتعين قيد الشركة في السجل التجاري لكي يبدأ الاعتراف لها بالثخصية المعنوية

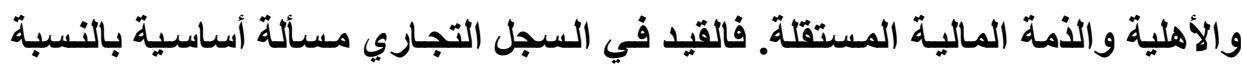

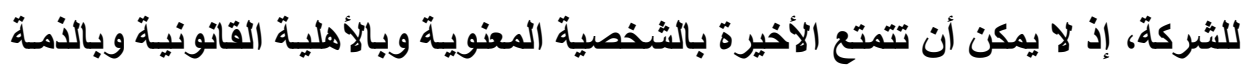

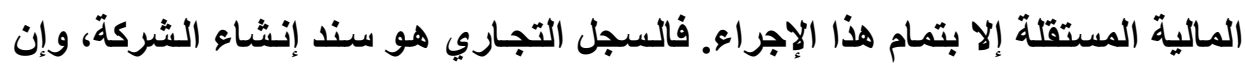

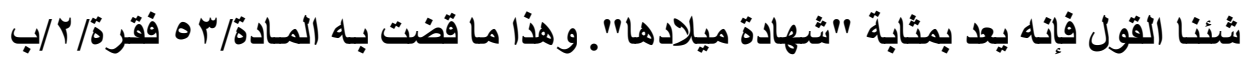


مـن القـانون المـدني، حيث قررت أن الشركة تكـون لهـا أهليـة، وبالتـالي ذمـة ماليـة

مستقلة، في الحدود التي يعينها سند إنشائهاب(') ثانياً: مكونات الأمة المالية للشركة:

تتكون الأمسة المـاليـة للشركة مـن أصـولها المتمثلـة في رأســالها وموجودهـا، وكذلك خصومها.

فتشتمل اصول الثركة على رأسمالها والعقـارات والمنقولات الماديـة والمعنويـة التي تمتلكها. ويتكون رأس المسال من الحصص التي يقدمها الشركاء، سـواء كانت حصصاً عينية أو نقدية. وإعمالاً لمبدأ استقلال الأمة المالية للشركة عن الذمم المالية للشركاء فإنه لا يجوز المساس برأس المال أو توزيعه بين الشركاء، حيث يظل مملوكاً للشركة طوال مدة بقائها.

أمسا الأموال والممتلكات فهي ما تحصل عليه الثركة بعد تأسيسها وبــ ممارسـة نشاطها عن طريق دخولها في علاقات تجارية مع الأغيار. أما خصوم الشركة فهي عبارة عن الديون والالتزامـات التي تترتب على كاهلها نتيجة تعاملاتها مع الغير، وتكون ملتزمة بالوفاء بها. وتجدر الإشارة إلى أن كل أصول الشركة من رأسمال وموجودات ضـامنة للوفاء بكل خصومها، وهذا هو مبدأ وحدة الأمة المالية كما أثرنا سلفاً (). والجدير بالذكر أنـه نظراً لارتبـاط الأمـة الماليـة للشركة بشخصيتها المعنويـة، وكونها إحدى نتائج تلك الشخصية، فإنه لا يمكن الاعتراف لجهة أو لكيان بتلك الأمـة (1) (انظر بحثنا في الأهلية الناقصة والمؤقتة للشركة، المرجع السابق، صه و وما بعدها.

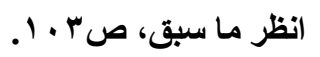


الماليـة إذا لــم تكـن تتمتـع بثخصية معنويـة. وهـا القـول يـصدق بالنسبة لـشركات

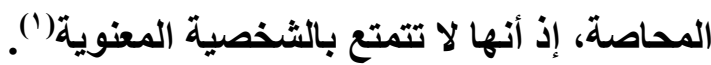

\section{الفزرع الثانتي}

\section{نتائج استقلال الذهة المالية لاشركة}

\section{عن الذهم المالية للشركاء}

يترتـب على اسـتقلال الأمــة الماليـة للـشركة عـن الـذمم الماليـة للـشركاء أو المساهمين فيها عدة نتائج تتمثل فيما يأتي: أولاً: ملكية الشركة لحصص الثركاء والمساهمين:

تنتقل الحصص التي يقدمها الثركاء أو المساهمون، والتي يتكون منها رأسمال الشركة، من الأمم المالية لهم إلى الأمة المالية للشركة وتصبح مملوكة لها، ولا يكون للشريك بعد ذلك، وطوال مدة بقاء الشركة، إلا مجرد نصيب في الأرباح. فأموال الشركة على هذا النحو لا تعتبر ملكاً شائعاً بين الشركاء، ولكن تكون ملكاً

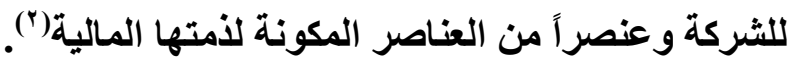
ويترتب على ذلك أنه إذا اتفق في عقد الشركة على استمرارها فيما بين الباقين من الشركاء في حالة وفاة أحدهم، فلا يكون لورثة الثريك المتوفى إلا نصيبه في أموال

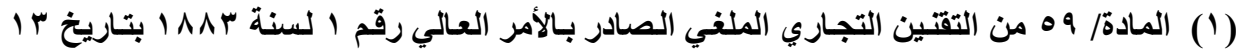

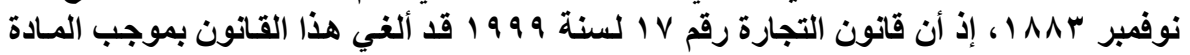

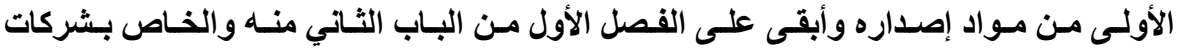

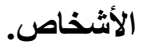

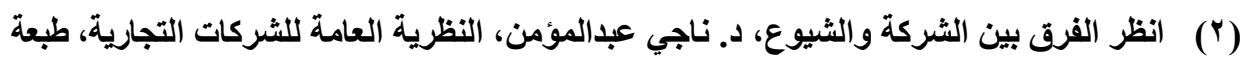

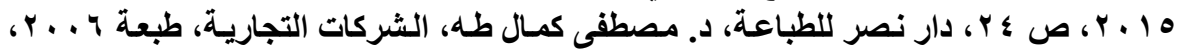
ص ب ؛ وما بعدها. دار المطبوعات الجامعية، الإسكندرية. 
الثركة، ويقدر هذا النصيب بحسب قيمته يوم الوفاة، ويدفع لهم نقداً، حتى ولو كاتت الحصة التي قدمها الثريك المتوفى حصة عينية وتم تقديمها للثركة على سبيل التمليك

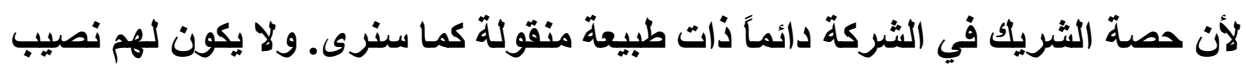
فيما يستجد بعد ذلك من حقوق إلا بقدر ما تكون تلك الحقوق ناتجة عن عمليات سـابقة على الوفاة.

ويتم احتساب نصيب الثريك المتوفى في أموال الشركة بإجر اء تصفية دفتريـة

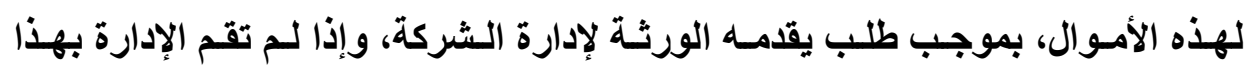
الإجراء يكون من حقهم اللجوء إلى القضاء.

وتجدر الإثـارة إلـى أنسه غالبـاً مـا يـدرج بنــ في عقد الشركة لا يجوز بموجبه. للورثة طلب إنهاء الشركة وتصفيتها ولا طلب وضع أحكام عليها. ثانياً: حصة الثريك أو المساهم ذات طبيعة منقولة:

تعتبر حصة الثريك في الشركة من المنقولات حتى ولو كانت تلك الحصة عقـاراً ويسري من ثم على الحصة كافة القواعد التي تنطبق على المنقول مثل إمكانية تداولها بالطرق التجارية الخاصة دون الحاجة لاستيفاء الإجراءات المقررة في القانون المدني. ولو كانت الحصة عقار وقدمت إلى الثركة على سبيل التمليك فلا يستلزم نقل ملكيتها

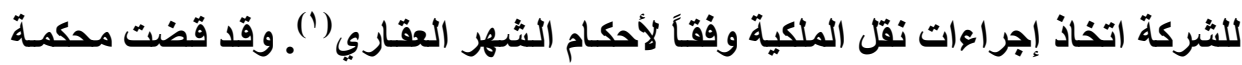
النقض في هذا الخصوص بتطبيق أحكام عقد البيع إذا كانت حصة الثريك حق ملكية أو أي حق عيني آخر آثره. وجوب تسجيل عقد الشركة حتى تنتقل ملكية الحصة العينية

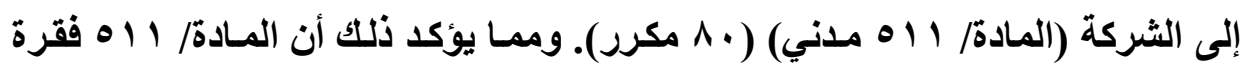

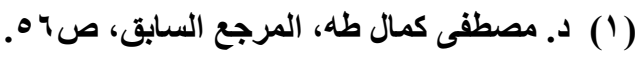

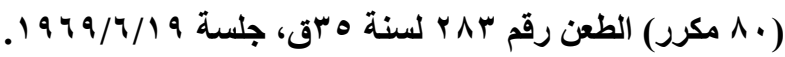


/ من القانون المدني تنص على انسه: "إذا كانت حصة الشريك حق ملكية أو حق

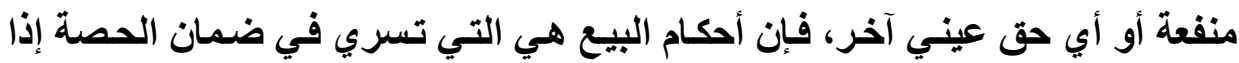

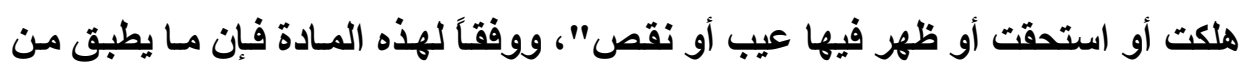

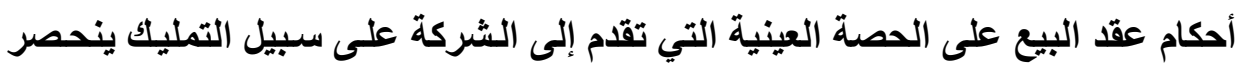

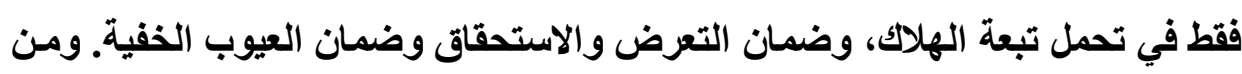

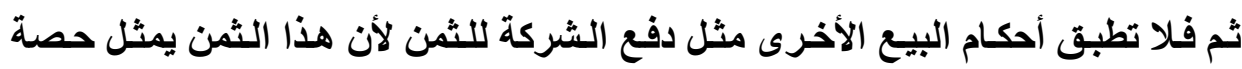

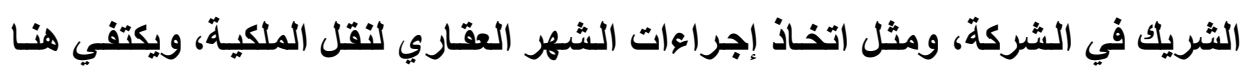
بقيل الشركة في السجل التجاري.

فهذا القيد هو الذي ينقل الملكية. وهذا القول يتسق ميع أحكام نقل ملكية الحصة

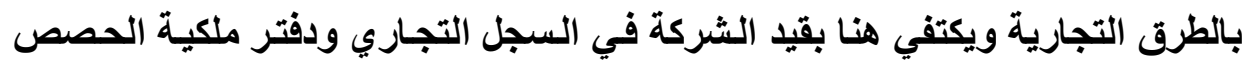

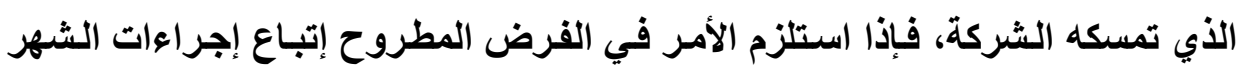

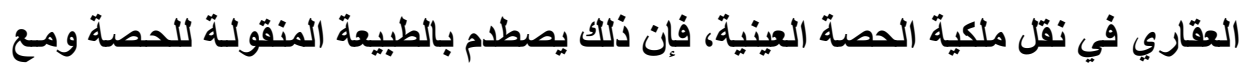
أحكام نقل ملكية الحصة بالطرق التجارية الخاصة.

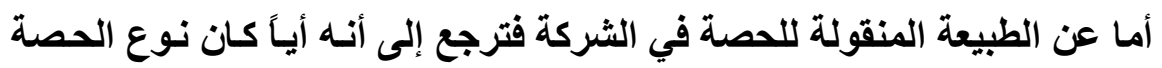

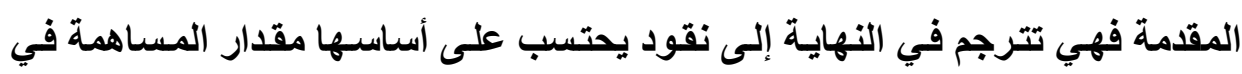

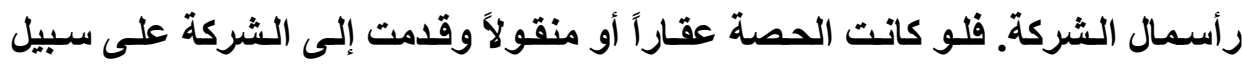

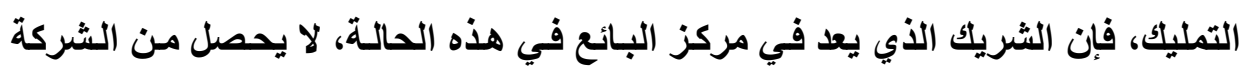

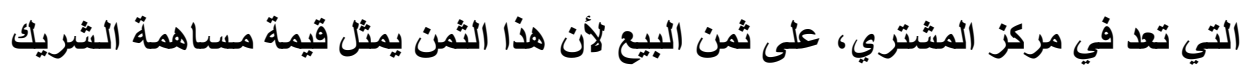

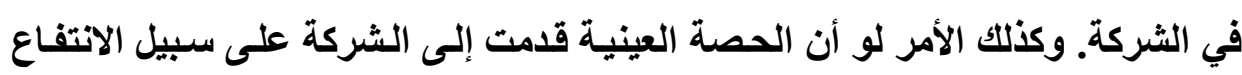

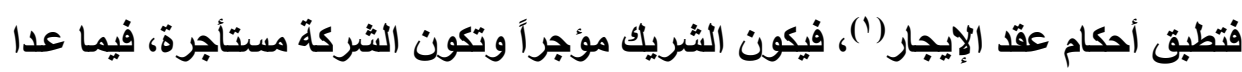

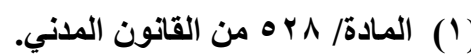


دفع الثركة للأجرة، فالشركة لا تدفعها لأن قيمتها تمثل مقدار مساهمة الشريك في

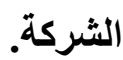

وعلى ذلك فإنه أياً كان نوع الحصة المقدمة من الثريك إلى الثركة فإنها تترجم في النهاية إلى قيمة نقلية، وبالتالي فهي دانئ أناً ذات طبيعة منقولة. ثالثاً: إفلاس الثركة أو الثريك:

بسبب استقلال الذمة المالية للثركة عن الذمم المالية للثركاء فيها، فإنه يترتب التباء على إفلاسها أو إفلاس أي من هؤلاء الثركاء النتائج الآتية:

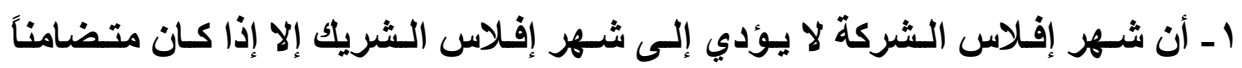

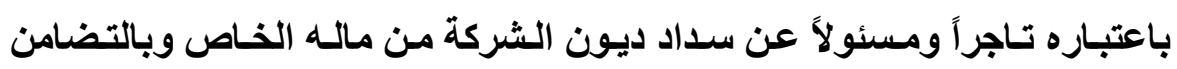

\section{معها.}

r- أن شهر إفلاس الثريك لا يؤدي إلى شهر إفلاس الثركة، وإن كان يؤدي في بعض

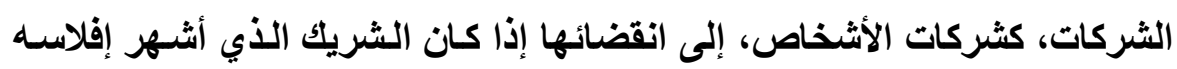

متضامناً (')

r- إذا أثهر إفلاس شركة التضامن أو التوصية البسيطة، فإن ذلك يستتبع شهر إفلاس

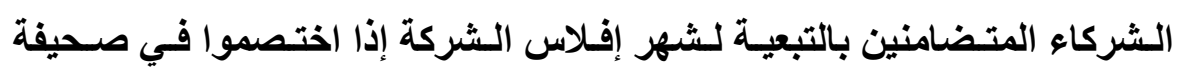

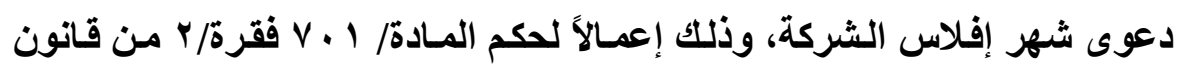

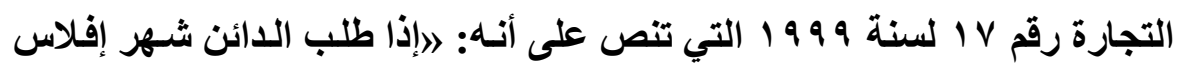
الشركة، وجب اختصام كافة الشركاء المتضامنينه.

(1) وتجدر الإثارة في هذا الخصوص إلى أن القول بأن شهر إفلاس الشركة لا يؤدي إلى انقضائها

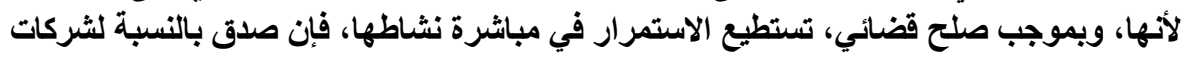

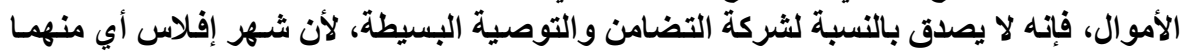
يؤدي على شهر إفلاس الثركاء المتضامنين، ويترتب على شهر إفلاس هؤلاء انقضاء الثركة. 
ومؤدي هذا النص أنسه إذا اختصم كل الشركاء المتضامنين في صحيفة دعوى شهر إفلاس الشركة، وصدر حكم بشهر إفلاس الأخيرة فإنـه يؤدي تلقائياً إلى شـهر

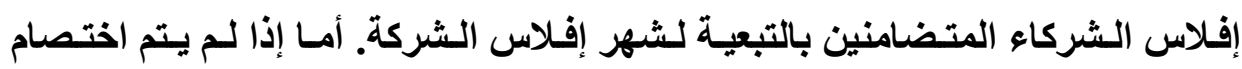
الشركاء المتضامنين فلا يشهر إفلاسـهم تلقائياً بالتبعيـة لشهر إفلاس الشركة، وإنمـا يجب رفع دعوى مستقلة بشهر إفلاسـهم ويقدم فيها الحكم الصـادر بشهر إفـلاس الشركة، ليصدر حكم آخر بشهر إفلاسهم مستقل عن حكم شهر إفلاس الشركة. وهذا النص يبدو في رأينا محل نظر وينطوي على تعقيد في الإجراءات لا مبرر لهل، إذ أن الثريك المتضامن مسئول عن سداد ديون الشركة من ماله الخاص بالتضامن معها،

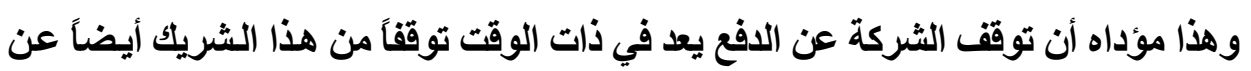

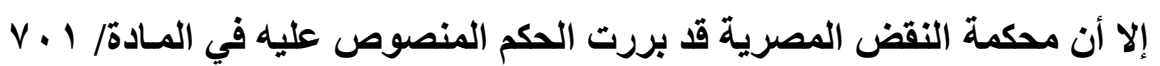
فقرة / ب سالفة الأكر بـالقول أنسه قد يكون من شـأن اختصام الشركاء المتضامنين في

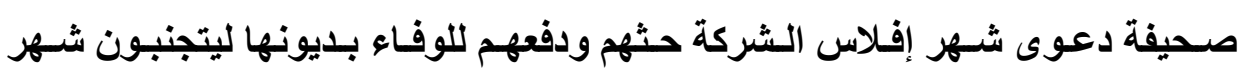
إفلاسها، وشهر إفلاسهم بعد ذلك(')

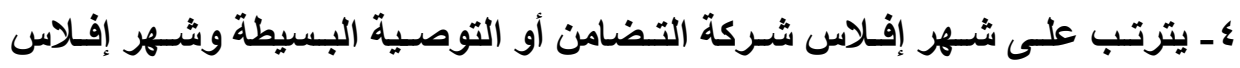
الشركاء المتضامنين فيها تعدد التفليسات. فتوجد تقليسة للشركة وتقليسة لكل

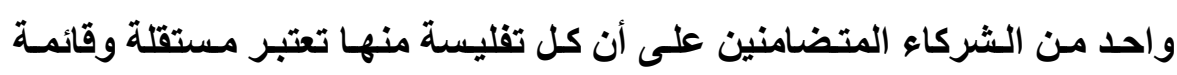

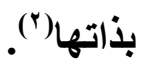


ويبدو اسـتقلال الذمـة الماليـة للشركة عن الذامم الماليـة للشركاء المتضامنين واضحاً في أن تفليسة الشركة لا تضم إلا دائنيها دون الدائنين الثخصيين للشركاء إلا أن لاائني الشركة التقدم في تفليسة الشركة المتضامنين، ولكنهم لا يتمتعون بأفضلية أو امتياز على الدائنين الآخرين، وإنما يتزاحمون مـع دائني الشركة ويخضع الجميع لقسمة الغرماء.

هـ لا يجوز لمدين الشركة أن يتمسك بإجراء مقاصة بين الاين المستحق عليه للشركة والدين المستحق له قبل أحد الثركاء. والعكس صحيح، فلا يجوز أن تقع المقاصـة بين دين على الشركة لأحد دائينها ودين للشريك في ذمة أحد مدينيه. وبتعبير آخر لا يجوز لدائن الشريك في الشركة، والذي أصبح مديناً لهذه الأخيرة، أن يتمسك باجراء المقاصة بين الاينين والعكس صحيح. ولكن إذا كان الثريك نفسه دائناً للشركة ومديناً لها في ذات الوقت فيجوز إجراء المقاصة بين الدينين، ولا يحول استقلال ذمتهما المالية دون إجراء هذه المقاصة. 7- إن الذمـة الماليـة للشركة هـي الضمان العـام لـانئنيها وحدهم الذين تعـاملوا معهـا بواسطة ممثليها، فلا يستفيذ من هذا الضمان الدائنون الشخصيون للشركاء. كمـا

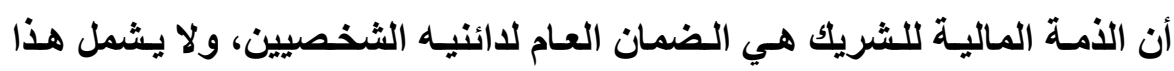
الضمان الدائنين الشخصيين للشركة.

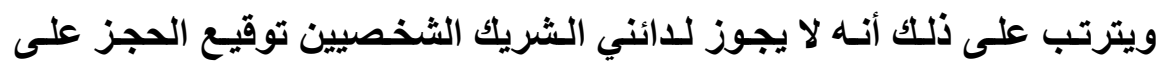

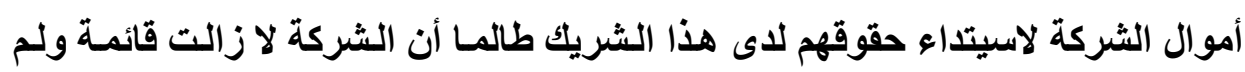

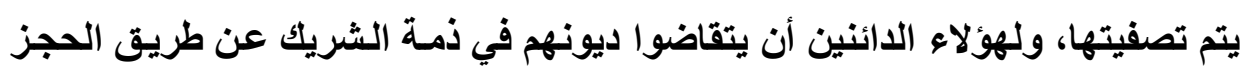


على مـا يخصه من الأربـاح فقط، وذلتك عن طريق الحجز على هذه الأربـاح تحت يـ الشركة بطريق حجز ما للمدين لاى الغير (')

وقد قضت محكمة النقض في هذا الخصوص بأن الحجز الموقع على مـال مملوك

للشركة وفاء لاين شخصي مستحق على أحد الثركاء قبل تصفية الثركة غير جائز (؟) لأن الثركة في هذا الوقت لازالت قائمة ومحتفظة بشخصيتها المعنوية وبذمتها المالية المستقلة.

أما إذا انحلت الشركة وتم تصفيتها فتزول شخصيتها المعنوية(")، وتزول بالتبعية لألك ذمتها المالية، وتصبح أموالها مملوكة على الثيوع بين الشركاء، ومن ثم يجوز للااننين الشخصيين للشريك أن يتقاضوا حقوقهم لديه من نصيبه في أموال الثركة بعد الثد

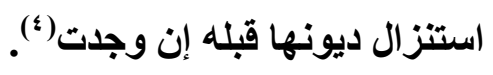

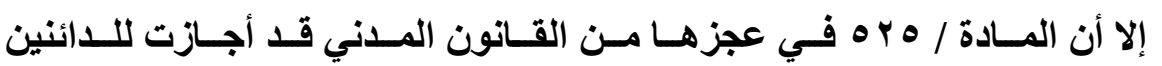
الثخصيين للشريك توقيع الحجز التحفظي على أموال هذا الثريك في الثركة قبل إتمام

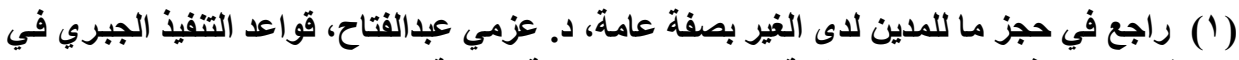

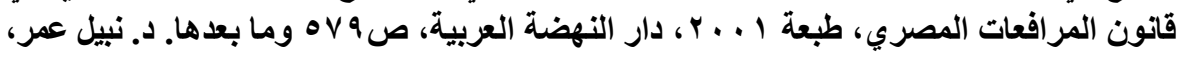

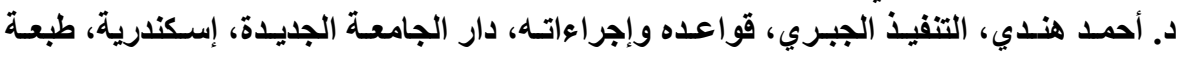

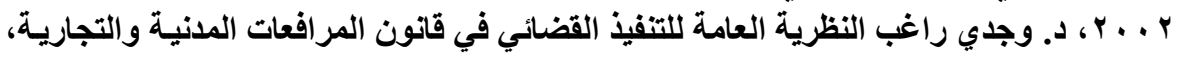

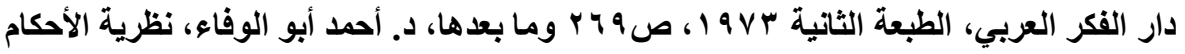

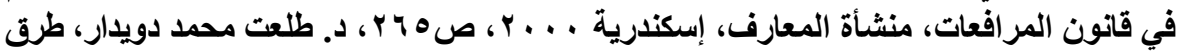

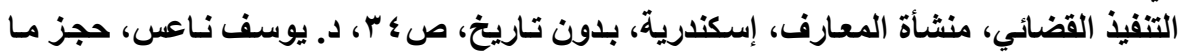

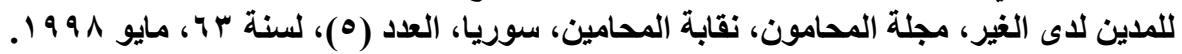

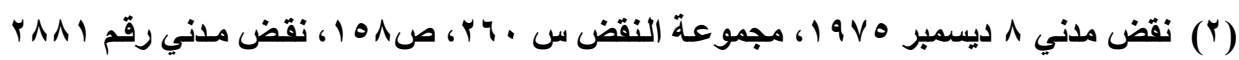

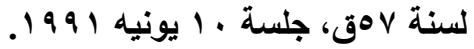

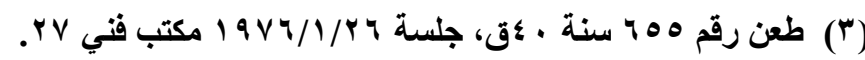

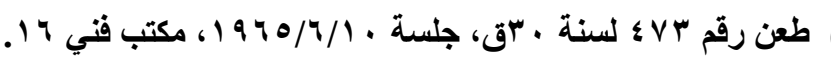


وهذا الحكم يبدو في رأينـا محل نظر، لأن المسادة/ 9 اب فقرة// مـن قـانون المرافعات التي تتظم الحجز التحفظي، ضمن مواد أخرى، تقضي بأنـه لا يوقع الحجز التحفظي إلا اقتضاء لحق محقق الوجود وحال الأداء. في حين أن نصيب الشريك في موجودات الثركة التي أجازت المادة المذكورة توقيع الحجز عليه، قد لا يكون محقق الوجود لأن الشركة قد تمني بخسارة ولا يكون لهذا الثريك أي نصيب في موجوداتها، وحتى ولو كان له نصيب في الموجودات فإن هذا النصيب غير حسل الأداء قبل إتمـام عمليات التصفية، ناهيك عن أن نصيب الشريك في الموجودات في هذا الوقت ليس هوديس

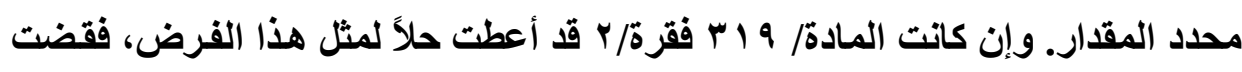
بأنـا إذا كان الدين غير معين المقدار، فـلا يوقع الحجز التحفظي إلا بـأمر من قاضـي التنفيذ يأذن فيه بالحجز ويقدر دين الحاجز تقديراً مؤقتاً. وقد قضت محكمة النقض في هذا الخصوص بأنه:

- اإن قيام المصفي بحصر الديون المطالب بها وإدراجها في كشوف التصفية تمهيداً لتخصيص مقابل للوفاء بها عند ثبوتها لا يعني إقراره بها أو أنها خالية من النزاع

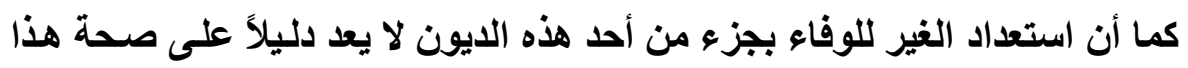

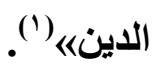

- اتترتب على التصفية ما دامت لم تتم ولم يكن منصوصاً في عقد الثركة على توقيت المدة المتفق عليها لإتمام التصفية فإن تقدير قيمة موجودات الشركة ومـا قد يطرأ عليها من نماء يكون مرهوناً بوقت التصفية وليس بوقت حدوث السبب الموجب

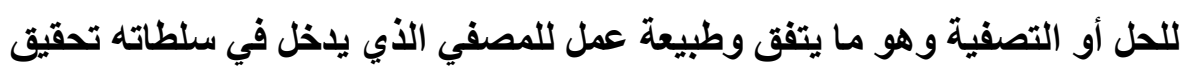


الغرض المقصود من تعيينه وذلكك باستمرار استغلال موجودات الشركة للحفـاظ

$$
\text { على قيمتها حتى البيع) (') }
$$

يتضح من هذه الأحكام أن مقدار نصيب الثريك في الشركة لا يكون مستحق الأداء ولا محقى الوجود ولا معين المقدار إلا بعد إتمام عملية التصفية. الاطباب الثاني

\section{استثناءات هبدأ الاستقلال بين ذهة الشركة}

$$
\text { وذمم الثركاء فيها }
$$

هناك حالات لا تستقل فيها ذمة الشركة عن ذمم شركائها أو مساهميها، ويسأل هؤلاء عن ديون والتزامات الشركة في أموالهم الخاصة، وتوجد تلك الحالات سواء كان الشركاء متضامنين (الفرع الأول) أو غير متضامنين (الفرع الثاني).

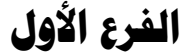

\section{عدم استقلال الذهة المالية للشركة عن الذهمي \\ المالية للشركاء المتضامنين}

يسأل الشريك المتضامن في شركة التضامن أو في شركة التوصية البسيطة عن سداد ديون الشركة في ماله الخاص وبالتضامن مع الشركة (أولاً). وقد يصل الاستقلال بين الأمـة الماليـة للشركة والأمـة المالية للشريك المتضامن فيها إلى حد مسئوليته وحده دون الشركة عن سداد ديون الأخيرة (ثانياً). 
أولاً: مسئولية الثريك المتضامن الثخصية والتضامنية عن سداد ديون الثركة:

يسـأل الـشريك المتـضامن عـن ســاد ديسون الـشركة مـن مالـه الخــاص ( )

$$
\text { وبالتضامن معها (广). (广). }
$$

1 - مسئولية الثريك المتضامن الثخصية عن سداد ديون الثركة:

تنص المادة/ Y من التقتين التجاري الملفي الصادر بالأمر العالي رقم 1 لسنة

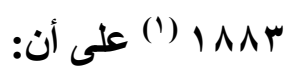

|الثركاء في شركة التضامن متضامنون لجميع تعهداتها ولو لم يحصل وضع الإمضاء عليها إلا من أحدهم إنما يشترط أن يكون هذا الإمضاء بعنوان الثركةهن. فجميع الشركاء المتضامنين، وليس الشريك المدير فقط، مسئولون عن سداد

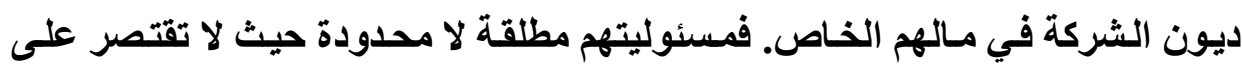

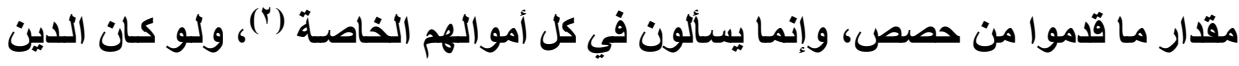

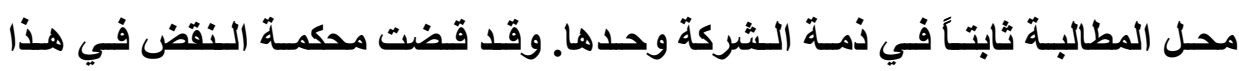

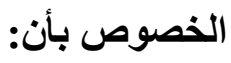

- الثريك المتضامن يسأل في أمو اله الخاصة عن كافة ديون الثركة، فيكون مديناً

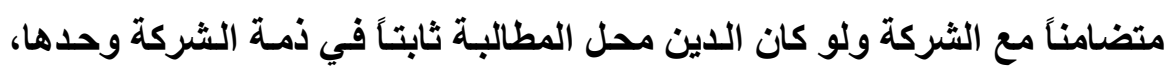

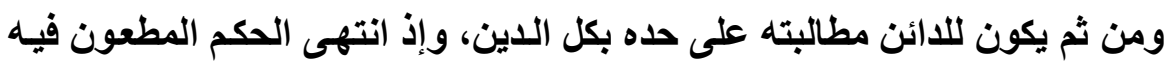
إلى التزام الطاعن بالرصيد المدين الذي ثبت في ذمسة الثركة بوصفه شريكاً

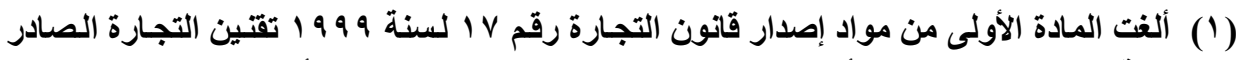

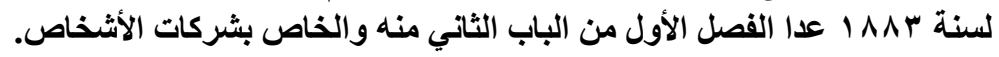


متضامناً وأن حق البنك المطعون ضده خصم هذا الرصيد من حسابه الجاري عملاً

بما ورد في عقود فتح الاعتماد، فإنه يكون قد التزم صحيح القانونهان ('). - >ــن المقرر أن الشريك المتضامن يسأل فـي أموالـه الخاصـة عن كافـة ديـون

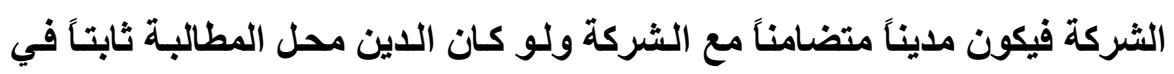

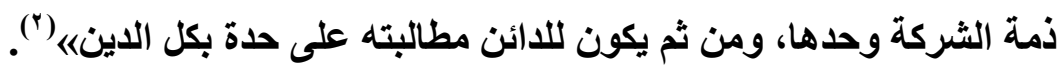
- 》الشريك في شركة التضامن يسأل في أموالـه الخاصـة عن كافة ديون الشركة

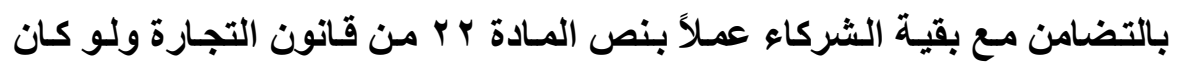
الاين محل المطالبة ثابتاً في ذمة الشركة وحدها، ودون نظر لنصيب الشريك في بـاءي

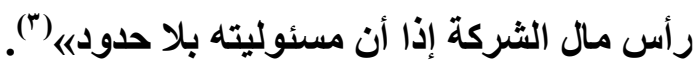

- >يعتبر الحكم الصادر على شركة التضامن حجة قبل الثريك المتضامن في الحدود

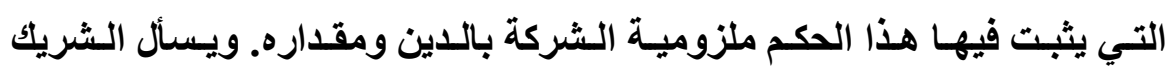
المتضامن - وفقاً للمادة r r من القانون التجاري - مسئولية شخصية وتضامنية عن ديون الشركة، وينبني على ذلك أن للشريك المتضامن بصفته الثخصية صفة في الطعن بالنقض على الحكم الصادر ضد الثركةه (؛).

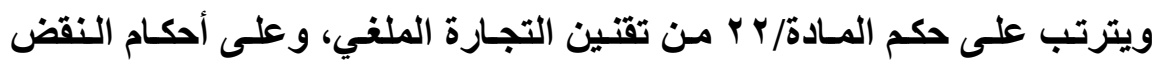
سـالفة الذكر، أن للائني الشركة ضمانان للحصول على ديونهم للدى الشركة، الأول:

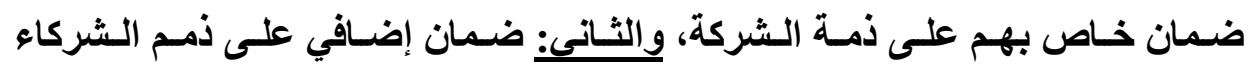
المتضامنين الشخـصية يتزاحمـون عليـه مـع الـدائنين الشخـصيين للشركاء. فـدائن 
الشركة، بسبب عدم استقلال ذمتها المالية عن الذمم الماليـة للشركاء المتضامنين، يكون له الرجوع على ذمة الثركة أو على ذمـة الشريك المتضامنين، أو على الذمتين معاً للحصول على دينه قبل الشركة.

إلا أن عدم استقلال الأمـة الماليـة للشركة عن الأمـة الماليـة للشريك المتضامن يكون فقط في العلاقة بين هذا الشريك ودائني الشركة، فذمـة الشركة وذمـة الشريك المتضامن ينصهران في بعضهما البعض ويضحيان كأنهمـا ذمـة مالية واحدة بالنسبة لهذا الدائن. أما في العلاقة بينه وبين الثركة والثركاء المتضامنين الآخرين، فلا يوجد استقلال للأمم المالية، فلو أو في أحد الثركاء بدين على الشركة جاز لله أن يرجع على الثى

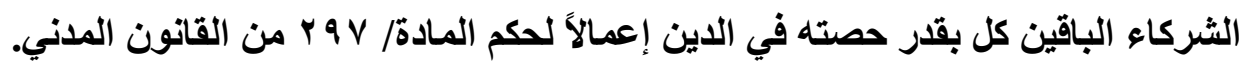

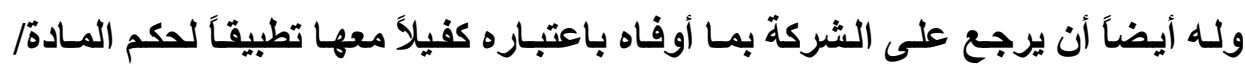
צ V من القانون المدني التي أعطت للكفيل حق الرجوع على المدين المكفول بالدين

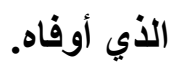

فعدم استقلال الذمـة الماليـة للشركة عن الذمـة الماليـة للشريك المتضامن مقرر

لصالح دائني الثركة وليس للشركة ذاتها أو باقي الشركاء المتضامنين فيها. وقاعدة مسئولية الشريك المتضامن عن سداد ديون الشركة في ماله الخاص هي

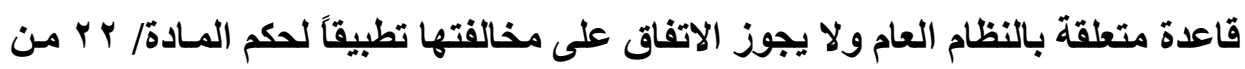
تقنين التجارة الملفي. إلا أن حظر هذا الاتفاق لتعلق القاعدة المذكورة بالنظام العام يرد عليه قيدان هما: القيــ الأول: إن عدم استقلال الأمسة المالية للشركة عن الأمـة المالية للشريك المتضامن والذي بموجبه يستطيع دائن الشركة أن يرجع على الشريك المتضامن في كل أمواله الخاصة لسداد دينه في ذمة الشركة، هو حكم مقررة لصالح دائني الشركة،

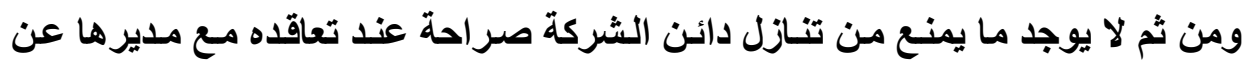


التمسك بمسئولية الشريك المتضامن اللامحدودة عن الالتزامسات الناثـئة عن هـا

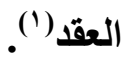

فـالحظر المسشار إليسه يتعلق بالنظـام العـام في العلاقة بـين الشركة والشركاء

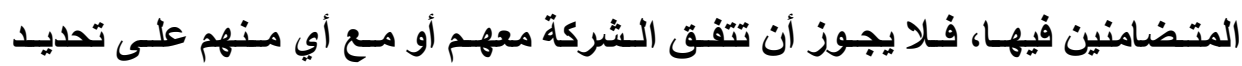

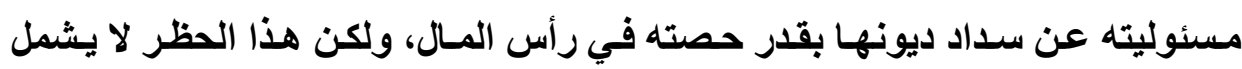
العلاقة بين الثركة ودائنيها.

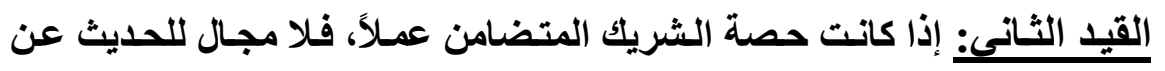

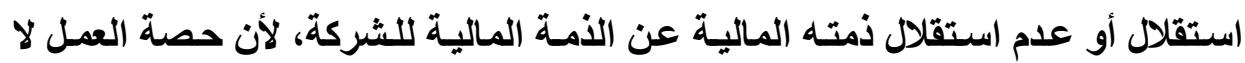
تدخل في تكوين رأسمال الشركة لأنها غير قابلة للتقيـيم بـالنقود، ولا يجوز أن تكون

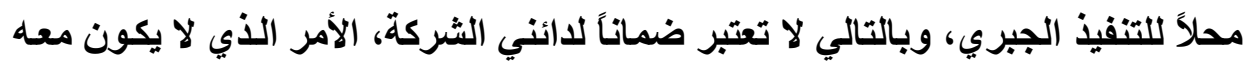
لاائني الثركة ضمانه على ذمة هذا النوع من الشركاء، ففي تلكك الحالـة لا يكون أمسام دائنـي الشركة سـوى ذمـة ماليـة واحدة يجـوز لهـم التنفيذ عليهـا، هـي الأمـة الماليـة للشركة. r ـ مسئولية الثريك المتضامن التضامنية عن سداد ديون الثركة: الشركاء في شركة التضامن، والشركاء المتضامنون في شركة التوصية البسيطة

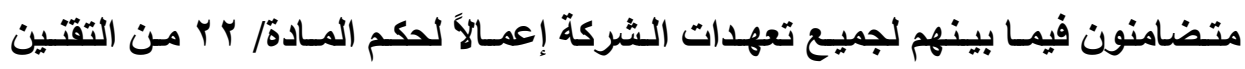
التجاري الملغي. وعلى الرغم من أن ظاهر النص المذكور يقيم التضامن بين الشركاء بعضهم وبعض، إلا أن أحكام النقض قد استقرت على أن هذا التضامن قائم أيضاً بين الثريك المتضامن والثركة، تأسيساً على أن الثريك المتضامن هو مدين متضامن مـع الشركة، ولو كان الدين محل المطالبة ثابتاً في ذمة الشركة وحدها، ومن ثم يكون لدائن 
الشركة مطالبة الثريك المتضامن على حدة بكل الدين باعتبار أن هذا الشريك مدين متضامن.

\section{وقد قضت محكمة النقض في هذا الخصوص بأن:}

- >الشريك في شركة التضامن يسأل في أموالـه الخاصـة عن كافة ديون الشركة

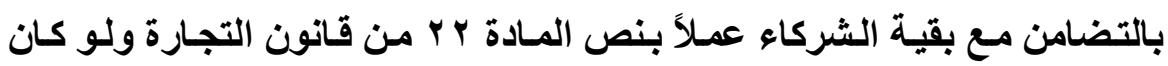
الدين محل المطالبة ثابتاً في ذمة الشركة وحدها، ودون النظر لنصيب الشريك في

رأس مال الثركة إذا أن مسئوليته بلا حدوده (')

- >إذا كان الطاعن باعتباره شريكاً في شركة التضامن يسأل في أمواله الخاصة عن

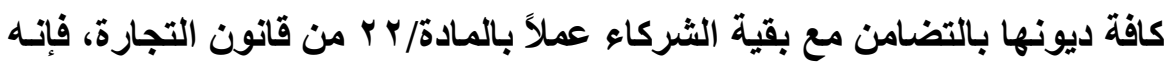
بموجب عقد فتح الاعتماد الرسمي المضمون برهن عقاري، والمبرم بين الشركة المطعون عليها باعتبار ها مرتهنة وبين الطاعن بصفته الشخصية باعتباره كفيلاً

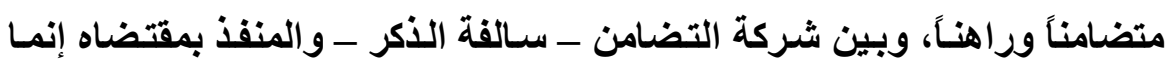
يجمع بين صفة المدين باعتباره شريكاً متضامناً في شركة التضامن الممثلة في العقد، وبين صفة الكفيل المتضامن باعتباره ر راهناً حتى ولـو كـان الدين محل التفيذ ثابتًا في ذمة شركة التضامن وحدهاه(؟) وهذا التضامن بين الشركاء بعضهم ببعض، وبينهم وبين الشركة، لسداد ديون الأخيرة، يعد أحد مظاهر عدم الاستقلال بين ذمـة الشركة وذمم الشركاء المتضامنين فيها، إذ أن دائن الثركة يستطيع مطالبة الثركة أو الثريك حسب اختياره دون الالتزام بالترتيب في الرجوع. 
إلا أن محكمة النقض، ورغبة منها في الحد من العنت أو العسف، الذي قد يأتيه دائن الثركة بتعمده التنفيذ على أموال الشريك المتضامن الخاصـة دون أموال الشركة منه

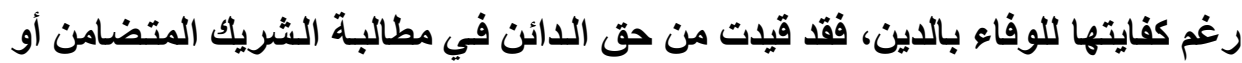
التنفيذ على أمواله دون الشركة بقيدين هما:

القيد الأول: أن يقدم الدائن ما يثبت دينه في ذمـة الشركة. ووسيلة الإثبات هنـا

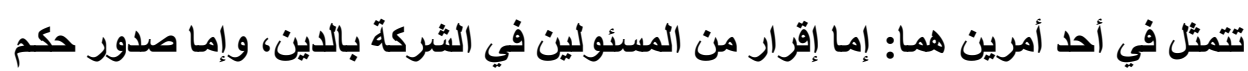

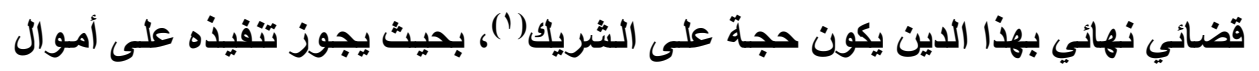
الشريك دون حاجة إلى الحصول على حكم في مواجهته(؟).

القيد الثاني: يجب أعذار الشركة أولاً والتنبيه عليها بالوفاء. فيحق للشريك أن يطالب الدائن بالتوجها إلى الشركة أولاً لمطالبتها بالوفاء. ولكن لا يستطيع أن يطالبه بأكثر من ذلك، فلا يجوز للشريك مطالبة الدائن بالبدء في التنفيذ على أموال الشركة

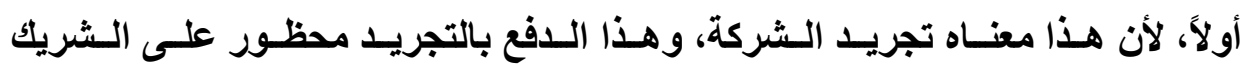
المتضامن باعتباره كفيلاً متضامناً وليس كفيلاً عادياً. وإذا استوفى الدائن هذين الإجراعين جاز له التنفيذ على أموال الثريك المتضامن الخاصة. ولكن ما أثر هذين القيدين على استقلال الأمـة المالية للشركة عن الأمـة المالية

للشركاء المتضامنين فيها؟ ون مسارئ 


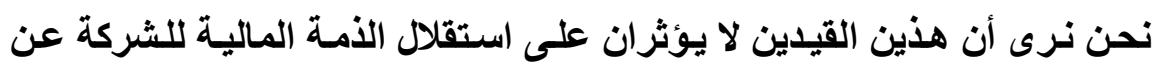

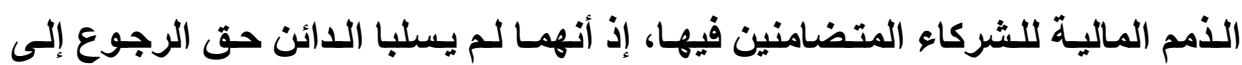

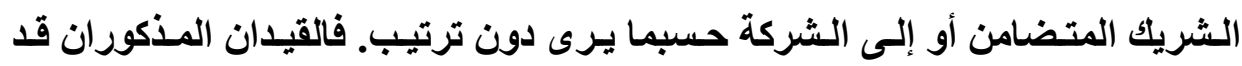

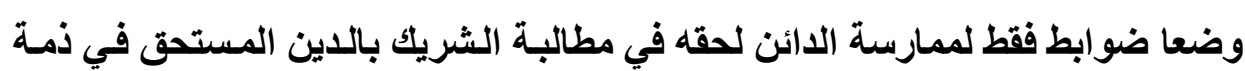

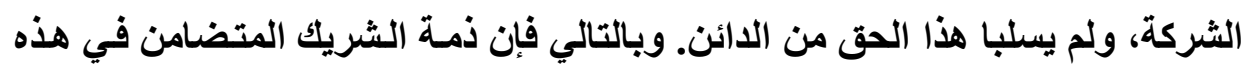

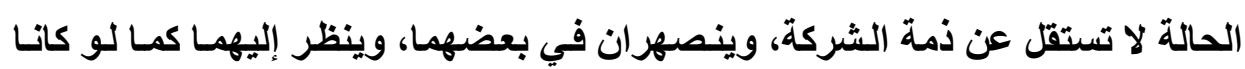
ذمة مالية واحدة.

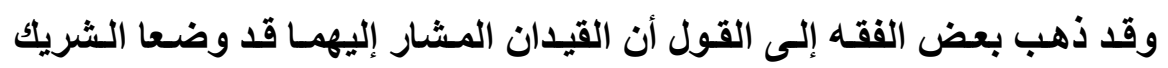

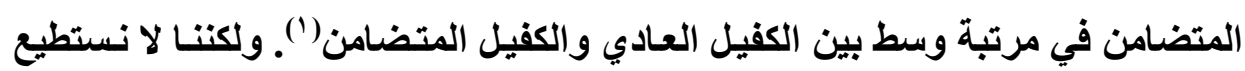

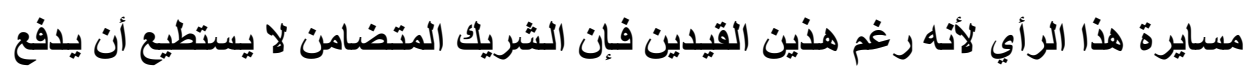

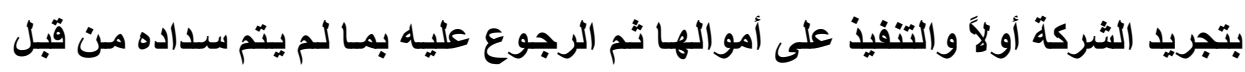

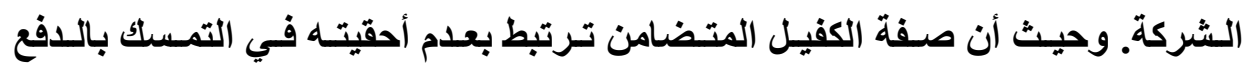

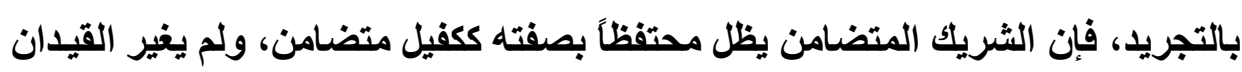
المذكوران من تلك الصفة. ثانياً: مسئولية الشريك المتضامن وحدة دون الشركة أو ميع الشركة في حالية تخارجه عن سداد ديونها:

هناك حالة لا يكون لاائني الثركة فيها سوى ذمة مالية واحدة يستطيعون التنفيذ

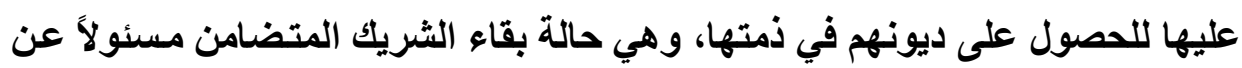

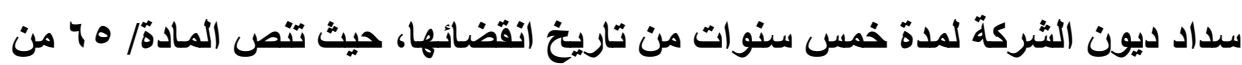

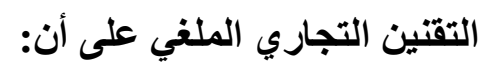


״كل مـا ينشأ عن أعمـال الشركة مـن الـدعاوي على الشركاء غير المـأمورين بتصفية الثركة أو على القائمين مقامهم يسقط الحق في إقامتها بمضي خمس سنين

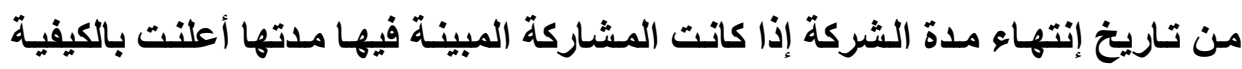

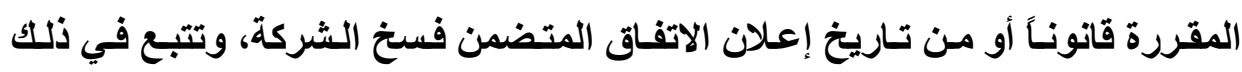

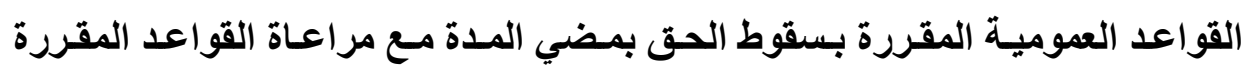
لانقطاعها《.

فالتقـادم الخمسي المنصوص عليهه في هذه المـادة يسري على الـاعاوي التـي يرفعها دائنو الشركة على الثركاء المتضامنين غير المصفين أو ورثة هؤلاء الشركاء لمطالبتهم بسداد ديون الشركة (1). ولفظ اللاعاوي المنصوص عليها في المـادة المذكورة يجب أن يفسر بـالمعنى الواسع للاعوى وليس معناها الضيق، بحيث يشمل هذا اللفظ إجراعات التنفيذ أيضاً. فإذا حصل الدائن على حكم بلينه ضد الشركة قبل انقضائها، فيجوز له التنفيذ بمقتضاه ضد الثريك المتضامن لمدة خمس سنوات من تاريخ انقضاء الشركة. ففي مثل هذا الفرض، فإن انقضاء الشركة يؤدي إلى زوال شخصيتها المعنويـة وزوال ذمتها المالية المستقلة بالتبعية. فمن تاريخ الانقضاء يفقد دائن الثركة الضمانة التي كاتت مقررة لله في التنفيذ على ذمتها المالية، لزوال تلك الأمـة من هذا التاريخ.

(1) أثثر خلاف حول ما إذا كان من حق الشريك المصفي أن يتمكك بالتقادم الخمسي، أنظر في ذلك، أحكام النقض الفرنسي.

- Cass. Com. 28 Mai 1872, Dalloz 1872-1-1247;

- Cass. Com. 27 Mai 1914, S. 1914-1-425.

وكذلك في الفقه المصري، د. حسام محمد عيسى، الثركات التجارية، النظرية العامة للشركة وشركات

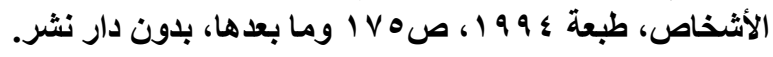


وبالتالي فلم يعد أمام دائني الثركة المنقضية سوى ذمة مالية واحدة يحق لهم التنفيذ عليها وهي ذمة الثريك المتضامن.

وعلى ذلك فلا مجال للحديث في تلكك الحالة عن استقلال أو عدم استقلال الأمـة المالية للشركة عن الأمة المالية للشريك المتضامن، لأن هذا الحديث يقتضي وجود ذمة دمة فئن

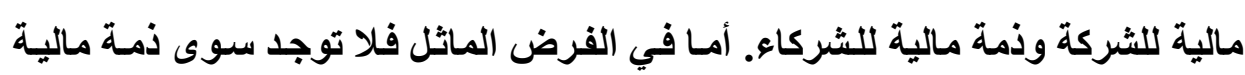

$$
\text { واحدة هي ذمة لشريك. }
$$

وإذا كانـت مـدة التقـادم المـذكورة تبـدأ مـن تـاريخ انقضاء الشركة، إلا أن الفقهـه والقضاء قد استقرا على أن تلك المدة تحتسب بالنسبة للشريك المتضامن المتخارج من تـاريخ تخارجـه إذا اسـتمرت الـشركة قائمسة بـين السشركاء الآخـرين، إذ أن الـشركة في هذا الفرض تكون قد انقضت بالنسبة لهذا الشريك فقط'(') وفي هذا الفرض يكون

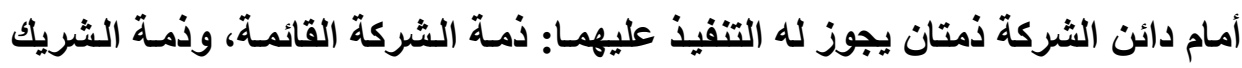

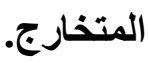

\section{الفرع الثاني}

\section{عدم استقلال الذهة المالية للشركة عن الذهمي}

\section{الكالية لاشركاء فير الإتضاهنين}

يسأل الشركاء غير المتضامنين عن ديون الشركة، مـن حيث المبدأ، بقدر حصصهم في رأس المسال. ولكن اسـتثناء مسن هذا المبدأ قد تكون مسئولية هـؤلاء

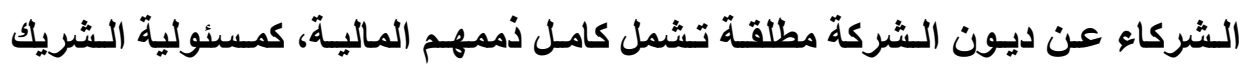

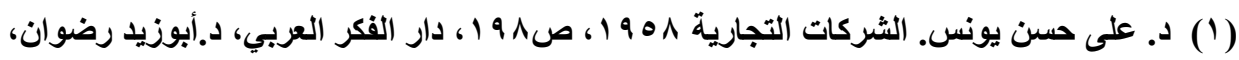

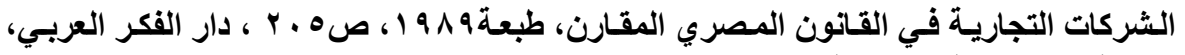

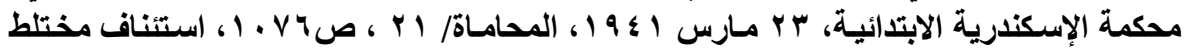

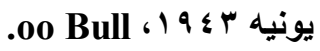


الموصي الذي يدخل اسمه في عنوان الشركة أو يتدخل في إدارتها الخارجية (أولا)،

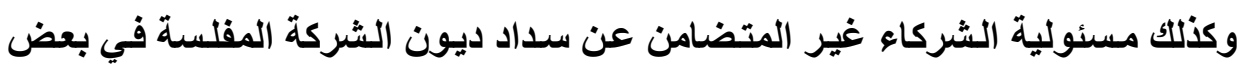
الحالات (ثُانياً). أولاً: عدم استقلال الذمة المالية للثريك الموصي عن الذمة المالية للثركة: الأصل ألا يسأل الثريك الموصي عن ديون الثركة إلا بقدر نصيبه في رأسمالها حيث تتص المادة/ V من التقنين التجاري الملفي على أن: >الشركاء الموصون لا يلزمهم من الخسارة التي تحصل إلا بقدر المـال الذي دفعوه أو الذي كان يلزمهم دفعة إلى الثركةهاء. إلا أن تطبيق هذا الأصل مرهون بعدم دخول اسم الشريك الموصي في عنوان

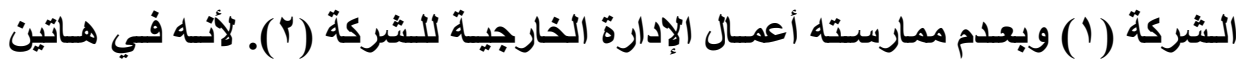
الحالتين ينقلب إلى شريك متضامن. 1ـ أثر دخول اسم الشريك الموصي في عنوان الثركة على استقلال ذمته المالية عن

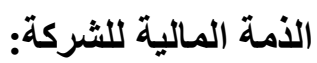
تنص المادة/ צץ من التقتين التجاري الملفي على أنه: ”الا يجوز أن يدخل في عنوان الثركة اسم واحد من الشركاء الموصين أي أرباب

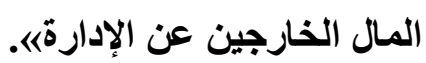
وتتص المادة/ 9 ؟ من ذات التقنين المذكور على أنه: "إذا أذن أحد الثركاء الموصين بلخول اسمه في عنوان الشركة خلافًاً لهـا هو

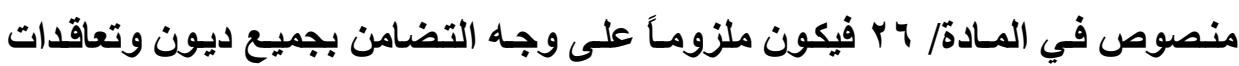
الثركةها. 


$$
\text { وتنص المادة/ ؛ ب من هذا التقنين على أن: }
$$

الكون إدارة شركة التوصية البسيطة بعنوان ويلزم أن يكون هذا العنوان اسم

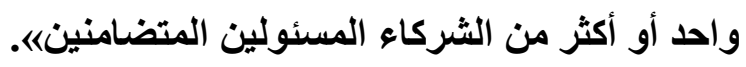

يتضح من المواد المذكورة أن اسم شركة التوصية البسيطة يتكون من اسم واحد أو أكثر من الثركاء المتضامنين مقروناً بما ينبئ عن وجود شركة. ولا يجوز أن يـخل

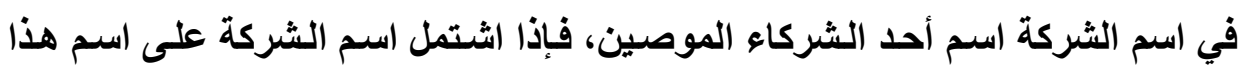
الشريك مع علمه بذلك اعتبر شريكاً متضامناً في مواجهة الغير. ولبيان أثر دخول اسم الشريك الموصي في عنوان الشركة على مسئوليته عن

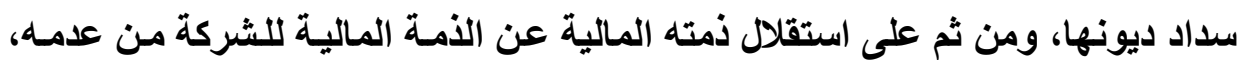
يتعين التفرقة بين فرضين هما: الفـرض الأول: إذا دخل اسـم الشريك الموصسي في العــوان بموافقتهـه أو بعلمـهـ ودون اعتراض منه، فإنه يعد في مواجهة الغير بمثابة الشريك المتضامن ويسأل من ثم عن ديون الشركة مسئولية شخصية في أموالهـ الخاصـة، أمسا في علاقاتـه مـع بـاقي الثركاء فإنه يظل شريكاً موصياً يجوز لله الرجوع عليهم بمقدار مـا دفعه بالزيـادة عن قيمة حصته. ويلاحظ أن مسئولية الشريك الموصي عن الديون في هذه الحالة تقوم بالنسبة للايون التي نشأت بعد دخول اسمه في العنوان. الفرض الثاني: إذا دخل اسم الشريك الموصسي في عنوان الشركة دون علمـه أو بعلمه ولكنه اعترض على ذلك، فإنه يظل شريكاً موصياً في علاقته بـالغير ولا يجوز

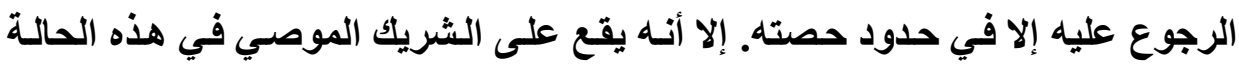
عبء إثبات واقعة عدم علمه بلخول اسمه في العنوان أو اعتراضه على ذلك. 
ففي الفرض الأول يتحول الثريك الموصي إلى شريك متضامن وتطبق عليه ذات أحكام مسئولية هذا الثريك، من حيث استقلال وعدم استقلال ذمته المالية عن الذمـة

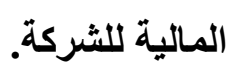

أمسا في الفرض الثاني فيظل الشريك موصياً ولا ينقلب إلى شريك متضامن، وبالتالي تكون ذمته المالية مستقلة عن الذمة المالية للشركة.

rـ أثر تلخل الثريك الموصي في أعمال الإدارة الخارجية على استقلال ذمته المالية عن الأمة

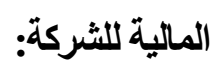

لقد حظرت المادتان/ ^ץ، ، ـ من تقنين التجاري الملغي على الشريك الموصي

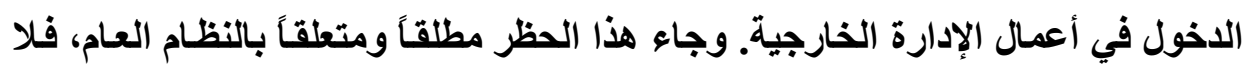

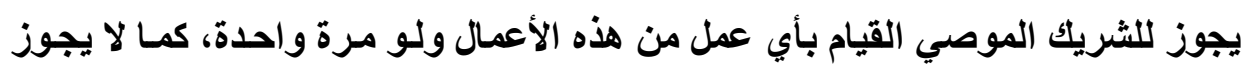

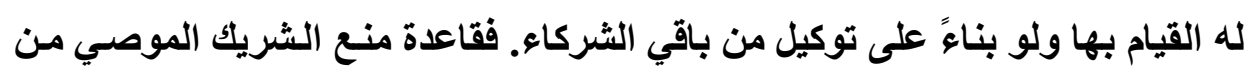

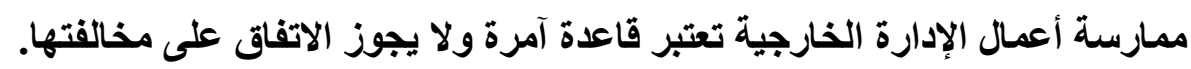
ويقصد بأعمال الإدارة الخارجية كل عمل يظهر الشريك الموصي كمـا لو كـان

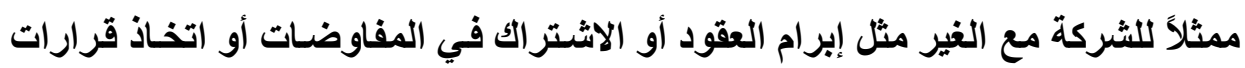

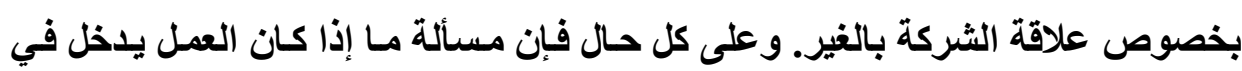

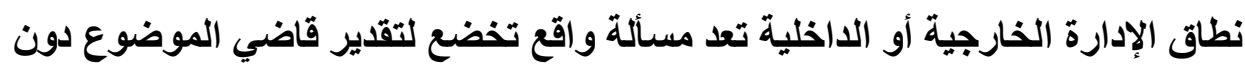
رقابة عليه من محكمة النقض.

أما عن أثر تدخل الثريك الموصي في أعمال الإدارة الخارجية على استقلال ذمته

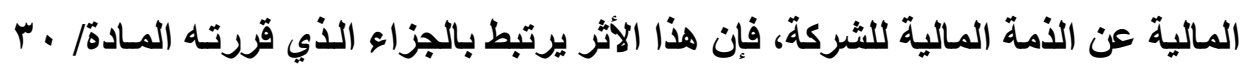

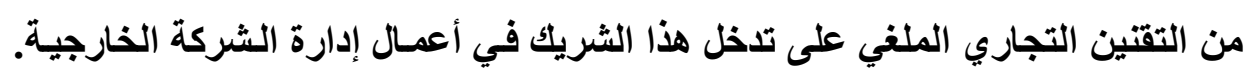

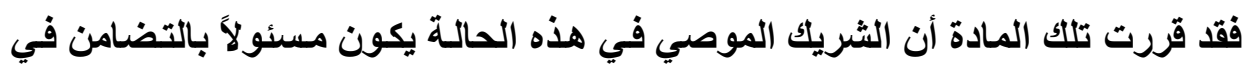
جميع أمواله عن ديون الثركة كما لو كان شريكاً متضامناً. 
إلا أن المادة المذكورة قد فرقت بين فرضين في خصوص مدى مسئولية الثريك أند

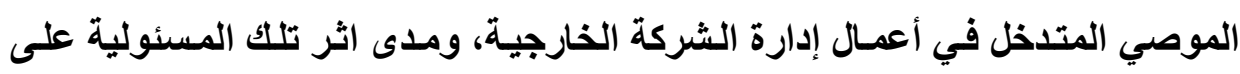
استقلال ذمته المالية عن الذمة المالية للثركة، وهذان الفركية الفرضان هما:

الفرض الأول: إذا كاتت أعمال الإدارة الخارجية التي قام بها الثريك الموصي

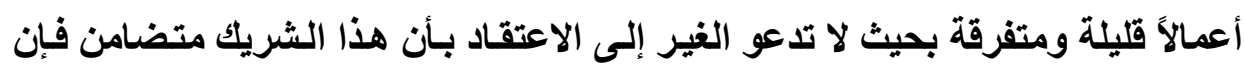

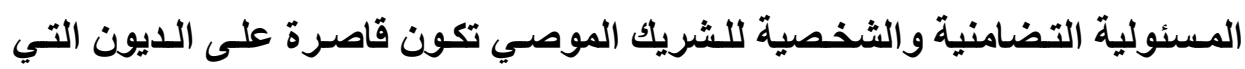
نشأت عن العمليات التي تلدخل فيها فقط، ولا تشمل العمليات الأخرى التي أبرمتها

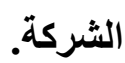

الفرض الثاني: إذا كان تدخل الشريك الموصي في أعمال الإدارة الخارجية يتت

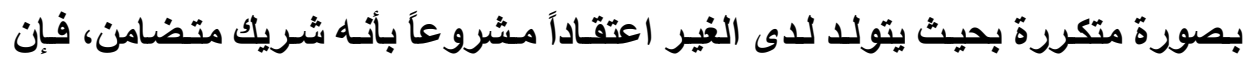

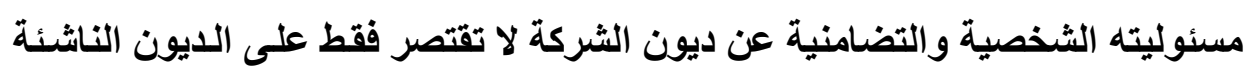

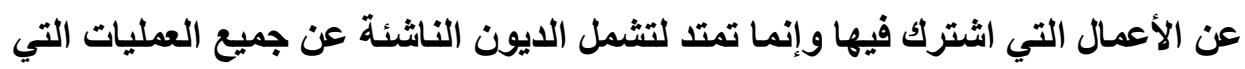
أبرمتها الثركة مع الغير حتى تلك التي لم يشترك فئها. وعلى كل حال، ووفقاً لحكم المادة/ • ب فقرة/ץ من التقنين التجاري الملفي، فيان

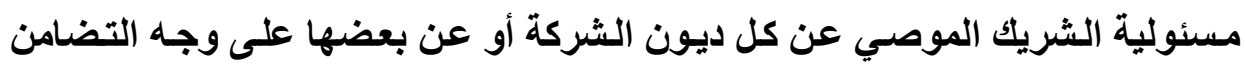

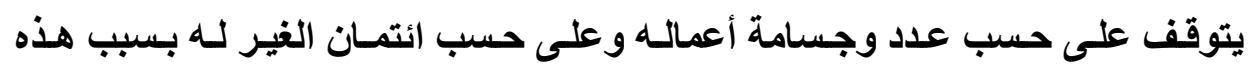

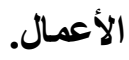
وقد قضت محكمة النقض في هذا الخصوص بأن:

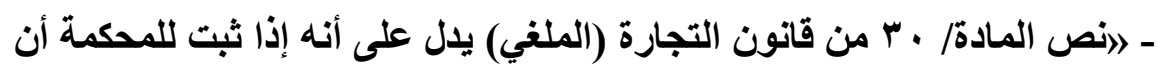

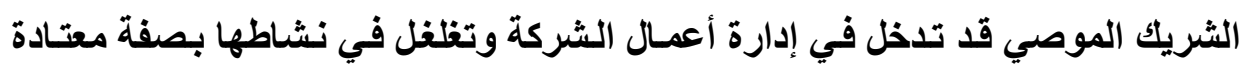

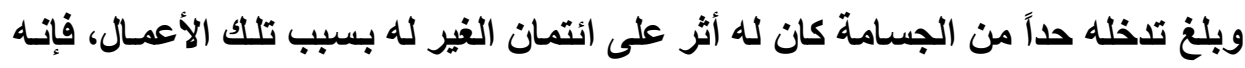

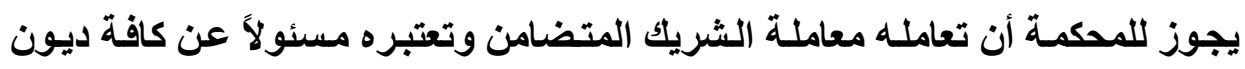


السشركة وتعهداتها مسئولية شخصية وتضامنيه قبل الـذين تعساملوا معهم أو قبـل

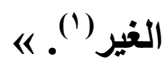

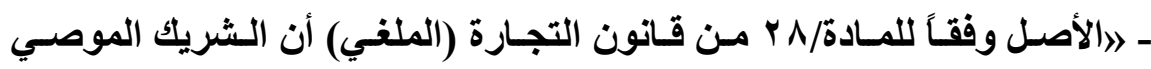

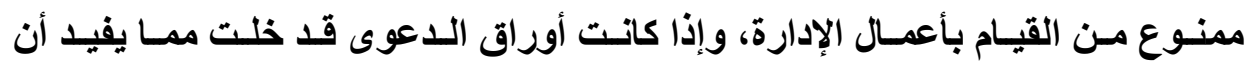

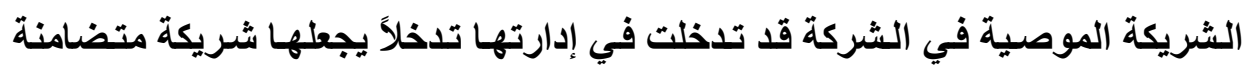
مسئولة عن ديون الثركة، وكان الحكم المنفذ به إنما صدر ضد الشد الشركة فإنه لا يجهوز

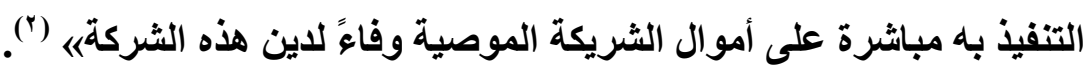
وترتيباً على ما سبق ففي الفرض الأول لا تستقل ذمة الشريك الموصي المتدخل

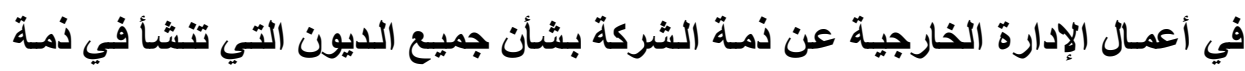

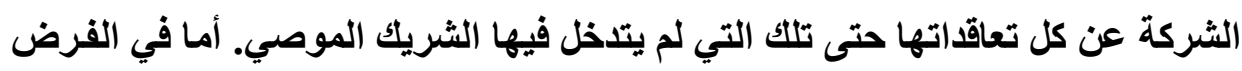

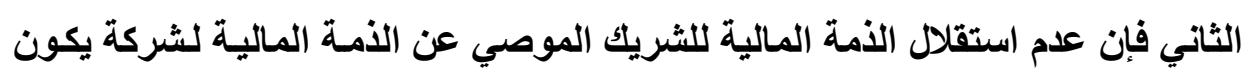

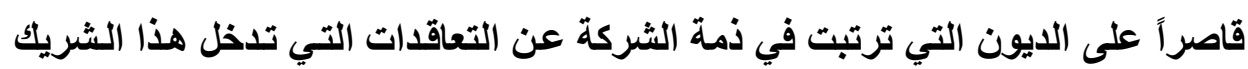
الموصي في إبرامها فقط. وتجدر الإثـارة إلى أن مصدر عدم استقلال الذمـة الماليـة للشريك الموصسي

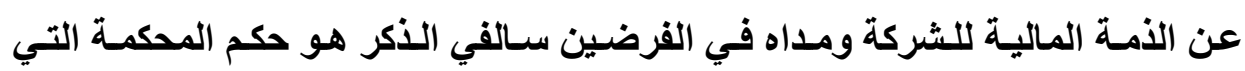

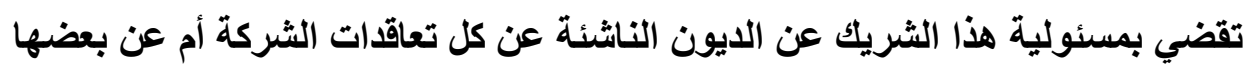
فقط. 
ثانياً: عدم استقلال الذمـة الماليـة للشركاء عن الذمـة الماليـة للشركة في حالـة إفلاسها:

لقد خطي المشرع المصري خطوة هامة في مجال حماية دائني الشركة المفلسة

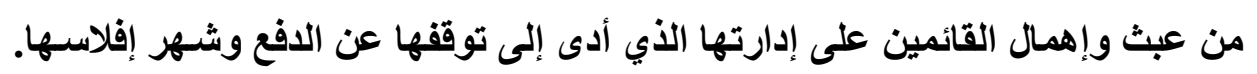

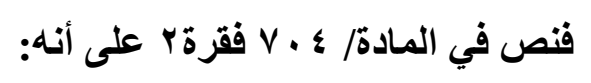

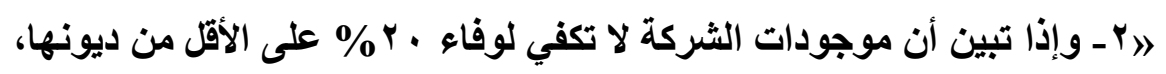

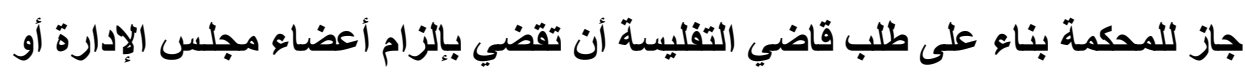

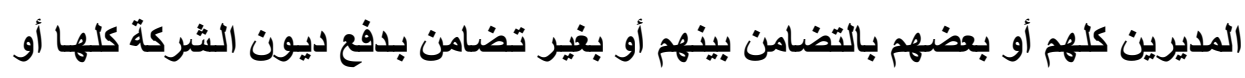
بعضها إلا إذا أثبتوا أنهم بذلوا في تدبير شئون الشركة عناية الرجل الحريصهي. فالمشرع بهذا النص أجـاز للمكمة أن تلزم أعضاء مجلس الإدارة أو المديرين

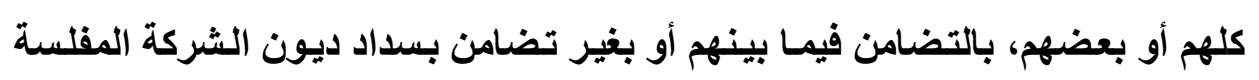

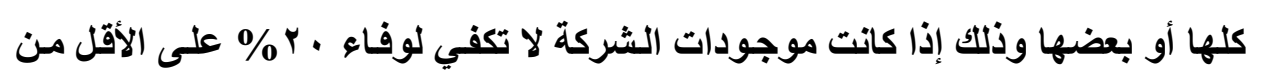
ديونها.

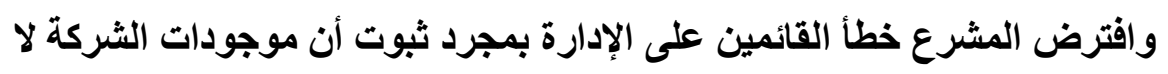

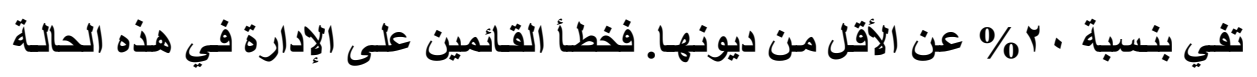
مفترض، ومن ثم يقع عليهم عبء إثبات أنهم لم يخطئون في الإدارة.

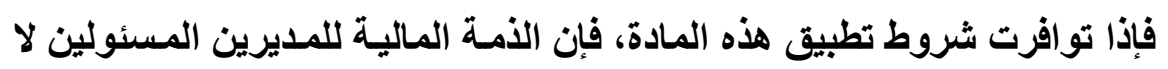

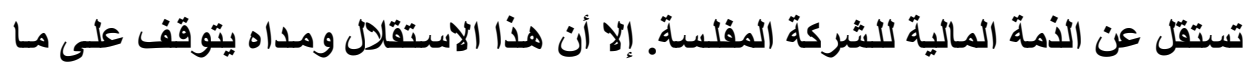

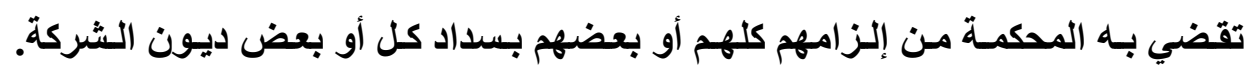

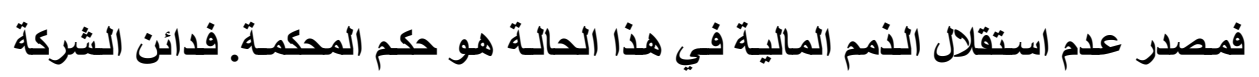

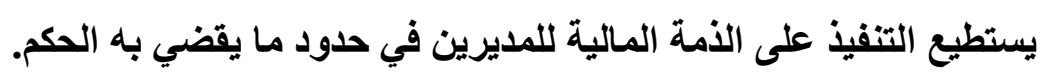


ونشير في هذا الخصوص إلى أن ذكر النسبة الواردة في المسادة المذكورة، وهي

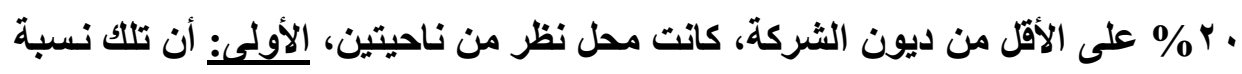

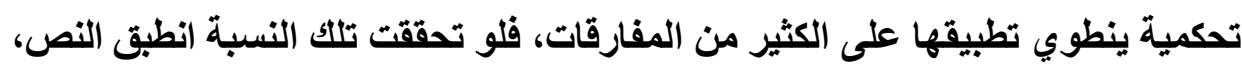
ولو لم تتحقق وكاتت مثلاً 9 , 9 1\% فلا يطبق النص. ولذا فإنتا نرى أن المشرع يجب أن

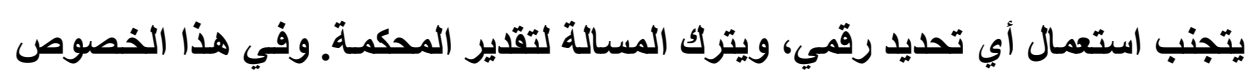

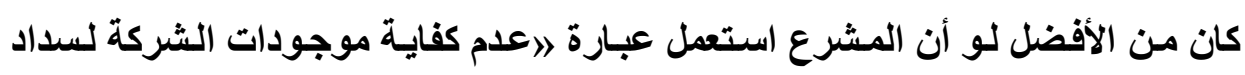

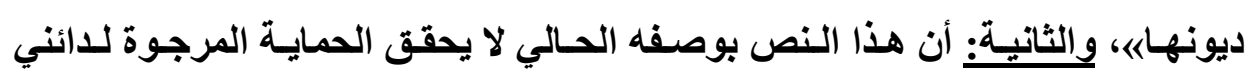
الشركة، فظاهر النص يعني أنه لا يطبق إذا استكمل المديرون موجودات الشركة لتصل

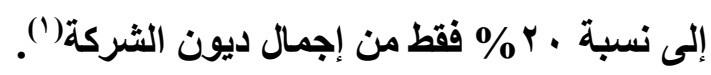

ثالثًا: موقف استقلال الذمـة الماليـة للشركاء الورثـة القصر عن الأمـة الماليـة

$$
\text { للشركة: مون }
$$

قد بينت المادة / ب ا من قانون التجـارة أحكام التزام القاصر إذا أمرت المحكمة

$$
\text { الاستمرار في تجارته، حيث تتص على أنه: }
$$

اإذا أمرت المحكمة بالاستمرار في تجارة الصغير أو المحجور عليه، فلا يلتزم إلا

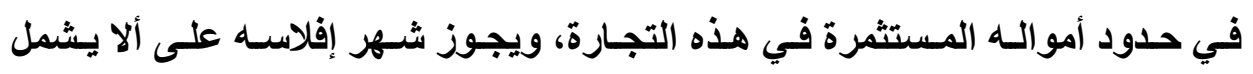
الإفلاس الأموال غير المستثمرة في التجارة. وفي هذه الحالة لا يترتب على الإفلاس أثر الثرة بالنسبة إلى شخص الصغير أو المحجور عليهاء.

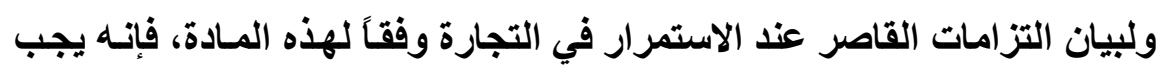
أن نفرق بين صورتين للاستمرار في التجارة، فقد يستمر القاصر في التجارة بمفرده أو 
بصفته شريكاً في شركة. وفي الحالة الأولى فسنكون أمسام نوع من تخصيص الذمـة

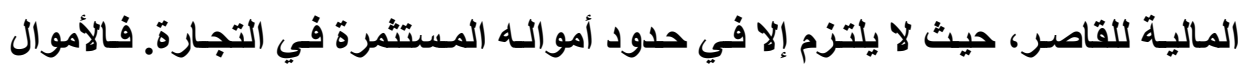
المخصصة فقط لهذه التجارة هي التي تضمن الوفاء بالديون الناشئة عن ممارستها،

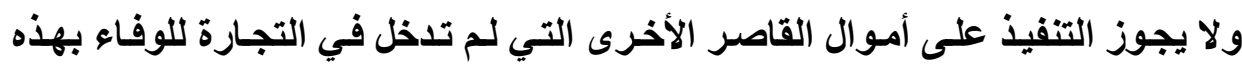
الايون، وفي هذا الفرض يجوز شهر إفلاس القاصر إذا توقف عن دفع الدايون المترتبة

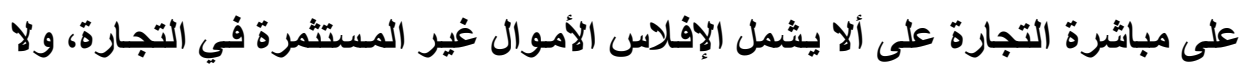
يطبق على القاصر آثار الإفلاس المتعلقة بشخصه.

أما إذا كان القاصر يستثر الأموال في التجارة عن طريق مساهمته في شركة

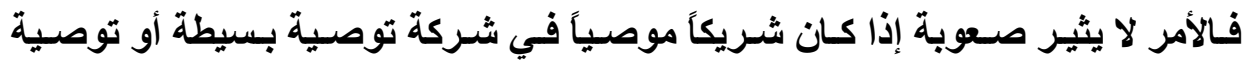

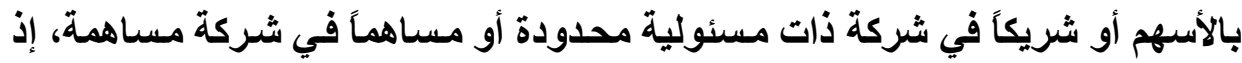

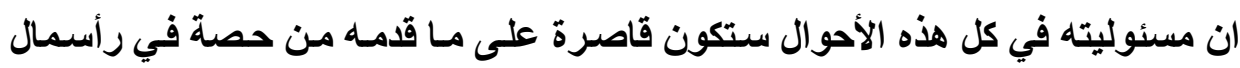
الثركة، أي أنه لن يلتزم إلا في حدود أموالـه المستثمرة. ولن يكتسب صفة الته التاجر، ومن ثم فلن يشهر إفلاسه.

إلا أن الصعوبة تثور في حالة ما إذا كان الاستمرار في تجارة القاصر كانت من

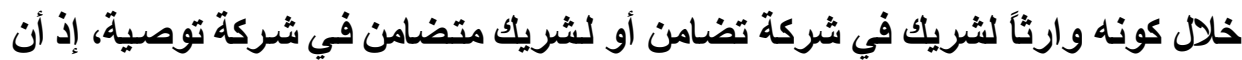

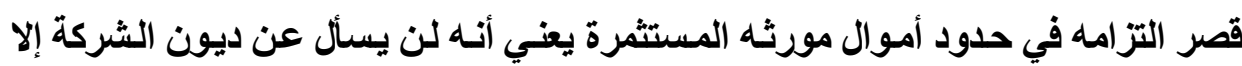

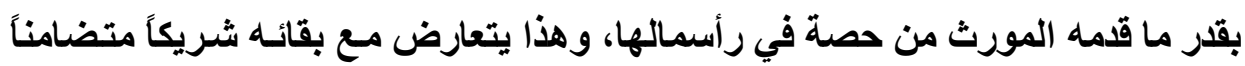
فيها لأن مثل هذا الثريك يسأل عن ديون الثركة في أمو الذه الخاصة مسئولية شخصية،

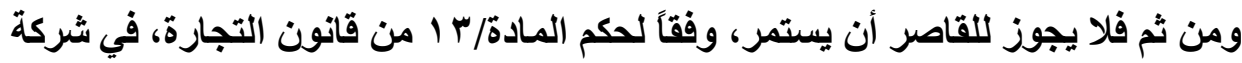

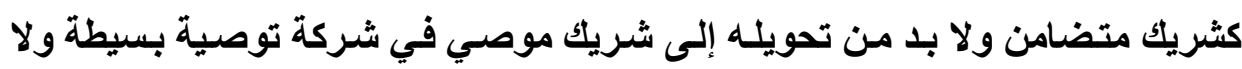

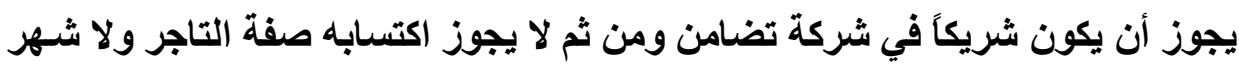


وما يهمنا في مجال هذه الدراسة ما جاء بالمـادة / آ ا من قانون التجارة سـالفة الذكر من أن إفلاس الثريك القاصر الوارث لا يشمل إلا الأموال المستثمرة في التجارة،

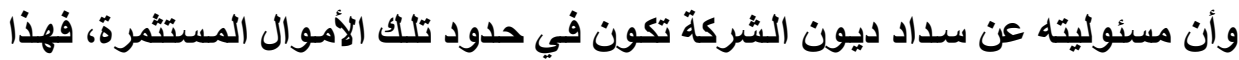

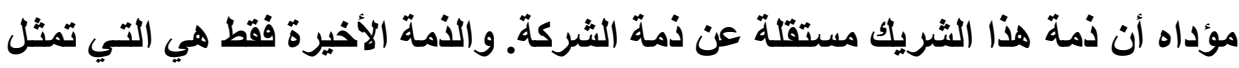

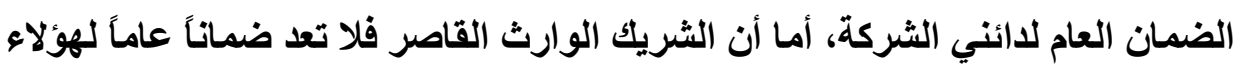

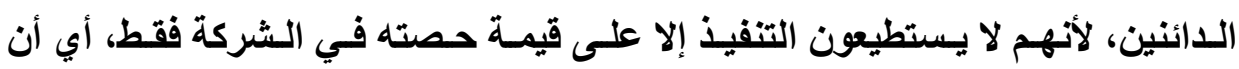
مسئوليته عن ديون الثركة مسئولية محدودة بمقار مساهمته في رأسمالها. 


\section{المبحث الثاني \\ الاستقلال بين ذهم الشركات المرتبطة}

هنـاك عدة أشـكال للـربط بين مجموعـة مـن الشركات (المطلب الأول)، ولهذا

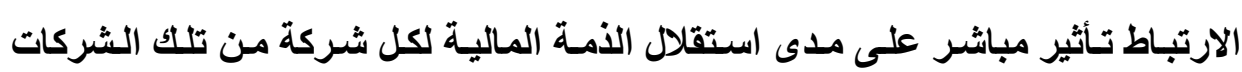

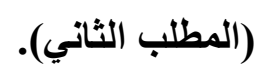

\section{المطلب الأول \\ أشكال الارتباط بين الشركات}

ترتبط الشركات بعضها ببعض عن طريق مـا يسمى مجموعة الشركات (الفرع

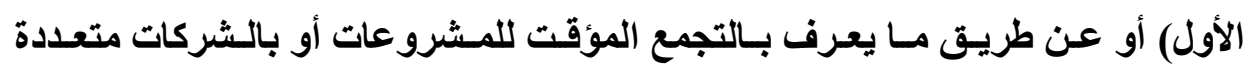
القوميات (الفرع الثاني).

\section{الفرع الأول \\ الارتباط بين الشركات عن طريق}

Lجموعة الشركات Le Groupe de Sociétés

قد ترتبط الشركات فيما بينها عن طريق مـا يسمى بمجموعة الشركات (أولاً)،

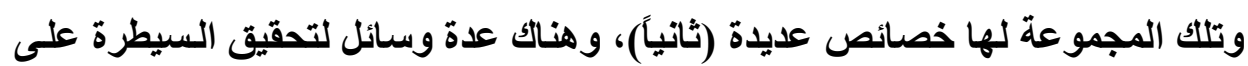
الشركات الداخلة في هذه المجموعة (ثالثاً). 
رغم ذيوع استعمال مصطلح مجموعة الثركات و انتثاره في الأوسـاط التجاريـة،

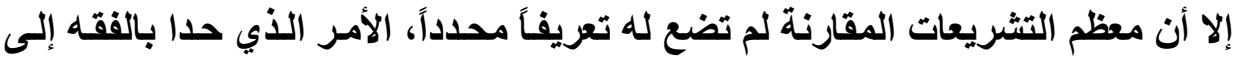
بذل محاو لات عديدة لتعريف هذا المصطلح وبيان المقصود منه. ومن بين التشريعات النادرة التي تناولت موضوع مجموعة الشركات بالتنظيم

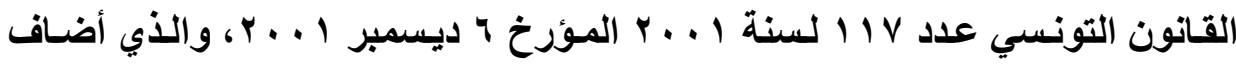

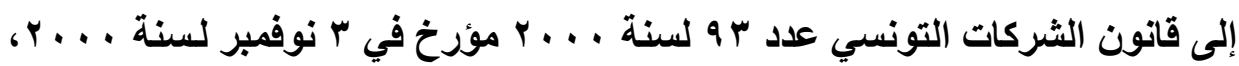

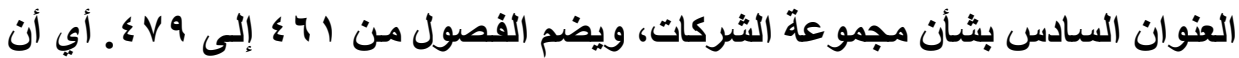
المشرع التونسي أفرد ثمان عشرة مادة لتنظيم تجمع الثركات. وقد عرف الفصل رقم ال7 ؛ من القانون المذكور تجمع الثركات بأنه:

|"مجموعة من الشركات لكل واحدة منها شخصيتها القانونيـة تكون مرتبطة بمصالح مشتركة، وتمسك إحداها، وتسمى الشركة الأم، بقية الثركات تحت نفوذهات القانوني أو الفعلي، وتمارس عليها رقابتها بثكل يؤدي على وتئ وحدة القرار. وتعتبر خاضعة لنقوذ شركة أخرى على معنى هذا العنوان كل شركة: - - تكون شركة أخرى ماسكة لنسبة من رأسمالها تمنحها أغلبية حقوق الاقتراع فيها، - أو تكون شركة أخرى ماسكة لأغلبية حقوق الاقتراع فيها بمفردها أو بمقتضى اتفاق مع شركاء آخرين، - أو تكون شركة أخرى متحكمة فعليًا في اتخـاذ القرارات في إطار جلساتها العامـة بمقتضى حقوق الإقتراع التي تتمتع بها بصفة فعلية. 
ويفترض وجود النفوذ متى كانت شركة ماسكة بصفة مباشرة أو غير مباثرة لأربعين في المائة على الأقل من حقوق الاقتراع في شركة أخرى على على ألا يكون هناك شريك آخر ماسك لنسبة أكبر منها.

ويجب أن تكون الثركة الأم مساهمة مباثرة أو بصفة غير مباثرة في رأس مال كل شركة من الثركات المنتمية إلى تجمع الثركات.

وتعتبر شركة فرعيـة كل شركة يرجع أكثر من خمسين بالمائسة من رأسمالها

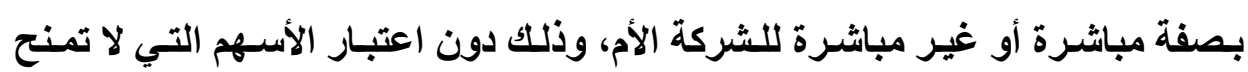

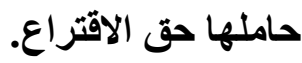
ولا يتمتع تجمع الثركات بالثخصية القانونيةها. ووفقاً للفصل الش؛ المذكور من قانون الثركات التونسي، نكون بصدد مجموعة

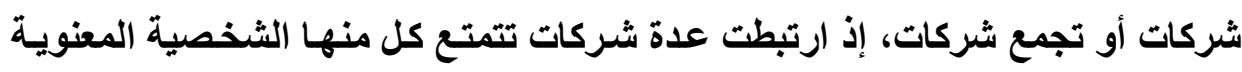

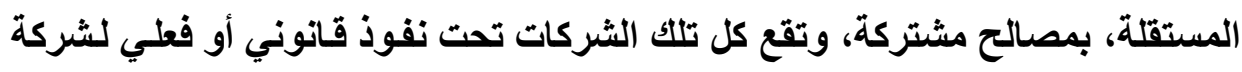

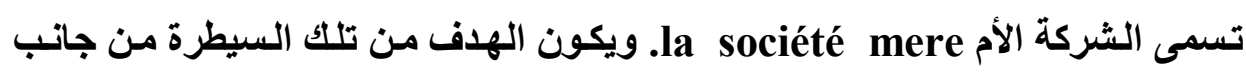
الثركة الأم توحيد القرار بين الثركات المنتمية لمجموعة الثركات.

وقد حدد الفصل المشار إليه حالات تحقق النفوذ القانوني أو الفعي للشركة الأم على باقي الثركات المنتمية لذات مجموعة الثركات. ومن أهم مـا جاء في تعريف الفصل المذكور لمجموعة الثركات أنها لا تتمتع

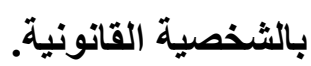

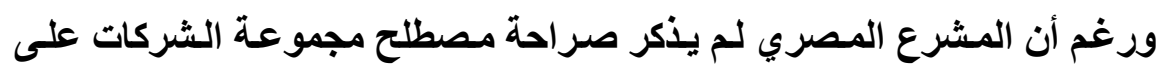

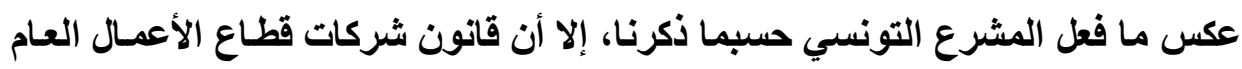

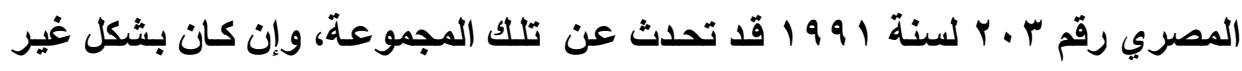


la société مباثر ، حيث أن مواد هذا القانون التي تناولت بـالتظيم الشركة القابضة Holding والشركة التابعة la société subsidaire

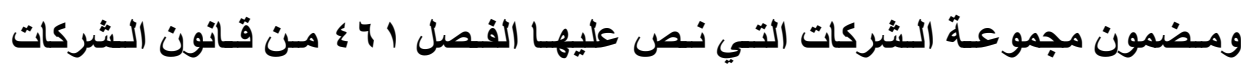

$$
\text { التونسي. }
$$

فتعريف قانون قطاع الأعمـال المصري المـذكور للشركة القابضة وبيـان وسـائل سيطرة الأولى على الثانية وأوجه تلك السيطرة والنتائج التي تترتب عليها، كل هذه

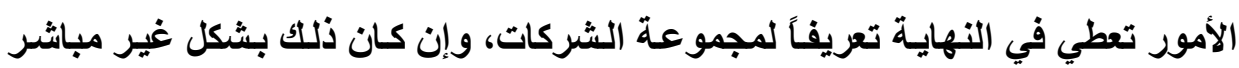

و هكذا يمكن القول أنه أينما وجدت شركة قابضة وشركة تابعة وجدت مجموعة الثركات. فتلك الثركات هي مصدر وسبب وجود مجموعة الثركات.

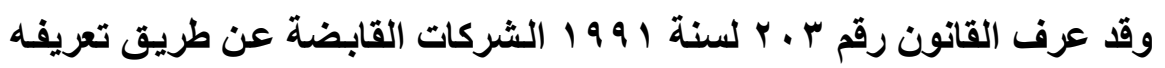
للشركات التابعة، حيث عرف الأخيرة في نص المادة/ 17 منسه بأن الشركة التابعة في تطبيق أحكام هذا القانون هي الثركة التي يكون لإحدى الشركات القابضة اهـ

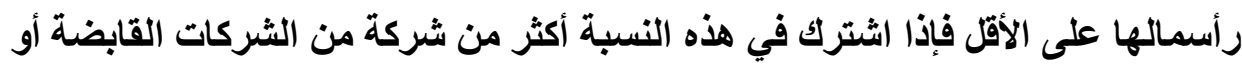

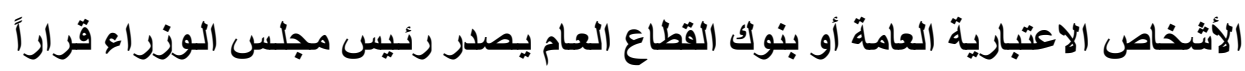
بتحديد الثركة القابضة التي تتبعها هذه الثركة. وأضـافت المـادة / r مـن القـانون المـذكور أن الشركة القابضة تتـولى مـن خـلال الثركات التابعة لها استثمار أموالها. 
ووفقاً لحكم المادة/ ا من هذا القانون يصدر بتأسيس الثركة التابعة قرار من

الوزير المختص بناء على اقتراح مجلس إدارة الثركة القابضة.

وعلى ذلك فِان الثركة القابضة تستمد سيطرتها على الثركة التابعة إمـا من

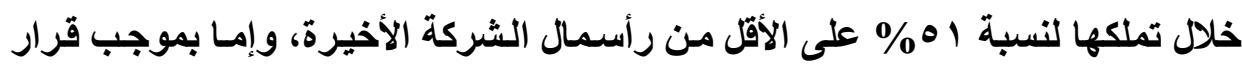

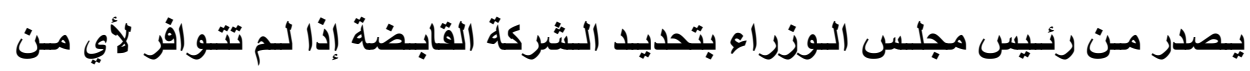
المساهمين في تأسيس الثركة التابعة النسبة المذكورة في ملكية رأسمالها. وتجدر الإشارة إلى أنه يمكن استعمال تعبير الشركة الأم والشركة الوليدة كبديل للثركة القابضة والثركة التابعة باعتبار أن العلاقة بين هذه الثنائيات تقوم على تملك الثك

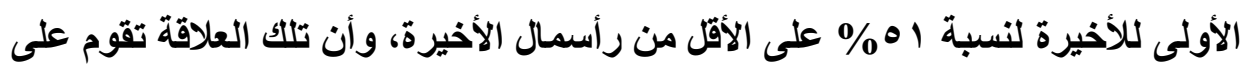

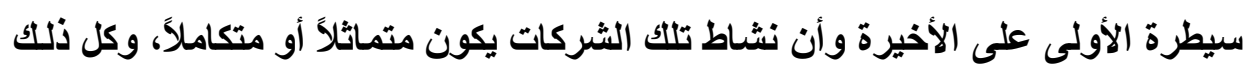

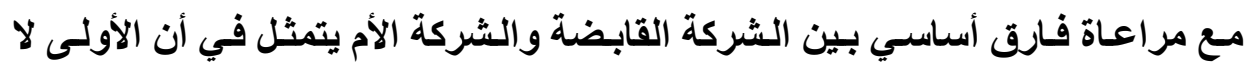
تمارس النشاط بنفسها ويقتصر دورها على المساهمة في رأسمال الشركات التابعة إذا لإنا

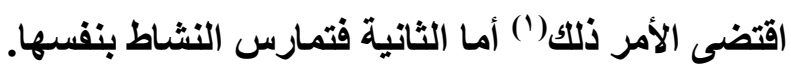
أما عن موقف الفقه من تعريف مجموعة الشركات فقد ذهب البعض من الفقه

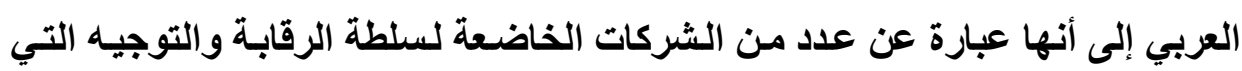

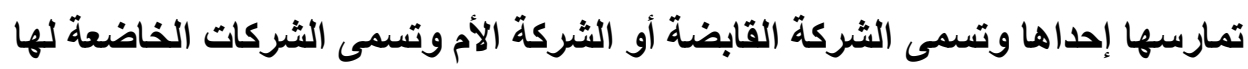

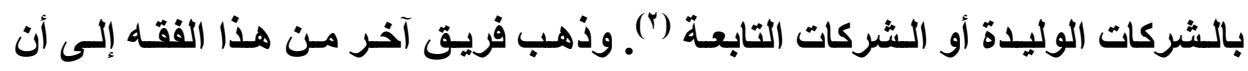


مجموعة الثركات هي نظام قانوني يضم عدد من الثركات تتميز باتحادها من الناحية

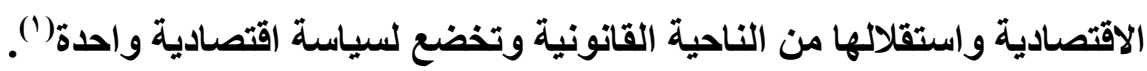
وذهب جاتب من الفقه الفرنسي إلى تعريف مجموعة الثركات بأنها عدة شركات مرتبطة تقوم فيها الثركة القابضة أو الأم بممارسة الرقابة على باتي باقي الثركات التابعة أو الوليدة، وتخضع لقرار اقتصادي واحد("). وذهب جانب آخر من هذا الفقه بأنها كيان

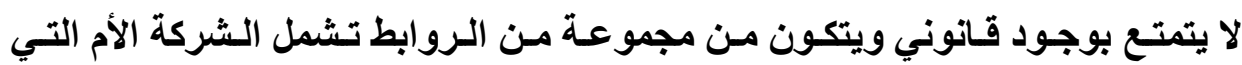

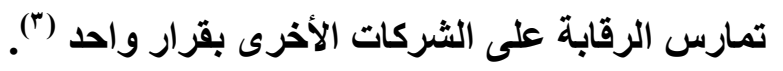

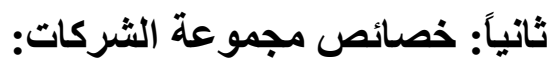

من خلال التعريفات التشريعية والفقهية لمجموعة الثركات يمكن استخلاص أهم

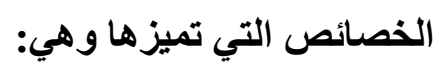

1 - لا تتمتع مجموعة الشركات بالثخصية القانونية، ومن ثم فليس لها ذمة مالية

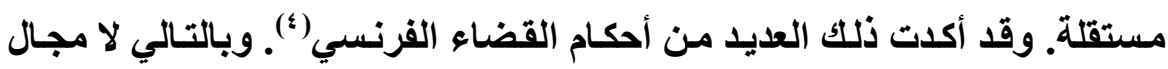

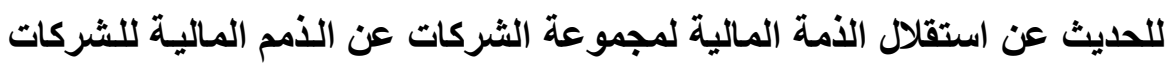

(1) د. محمود عمر : إثكالية امتداد شرط التحكيم بالتطبيق على قضية هضبة الأهرام، دراسة مقارنة،

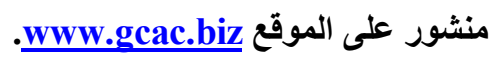

(2) Frederic magnas, les groups de société et la protection des interet catégoriele, sur le site. www.academia.edu.

(3) Huxinyu, le groupe de sociétés en droit francais et en droit chinois, thése Angers, France 2010.

(4) Cass. Soc. 14 Janv. 2014, No13-60165; Cass. Soc. 8 Oct 2014. No1314973 et no. 13. 14974; les sentences sur le site.

www.Lgifrance.gouv.fr 
الاخلـة فيهـا، ولكن الحديث عن الاسـتقلال مـن عدمـه يكـون بين الــمم الماليـة للشركات الداخلة في مجموعة الشركات.

r ـ تضم مجموعة الشركات شركتين أو أكثر توجد روابط بينها عن طريق سيطرة

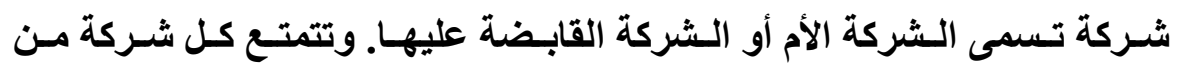
الشركات الاخلة في تكوين مجموعة الشركات بالشخصية المعنويـة المستقلة مـع ما يترتب على ذلك من تمتعها بذمة مالية مستقلة (').

Unité de الخضع الشركات المنتمية لمجموعة الشركات لمركزية ووحدة القرار la decision تسيطر على تلك الشركات وهي الشركة القابضة أو الشركة الأم. ويتعلق القرار الموحد بالسياسة الإستراتيجية والاقتصادية التي تهدف إلى تحقيق وتنفيذ سياسـة عامة موحدة لكل هذه الثركات.

ثالثًا: وسائل سيطرة إحدى الشركات على الشركات الأخرى المنتميـة لمجموعة

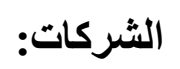

تـستمد إحـدى شـركات مجموعـة الشركات سـيطرتها على شـركات المجموعـة

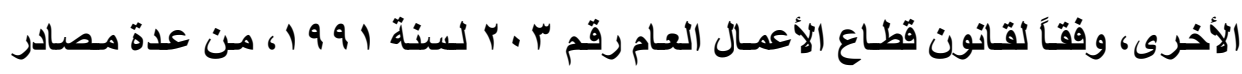
تتمثل فيما يأتي:

1 ـ تملكك الشركة القابضة لأغلبية الأسـهم في رأسمال الشركة التابعة، وهنـاك بعض

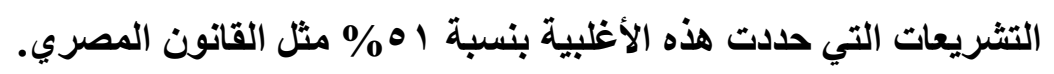

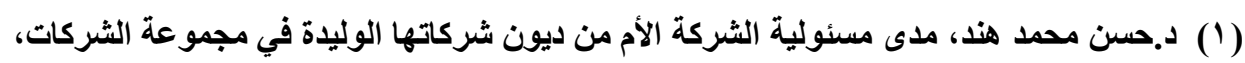

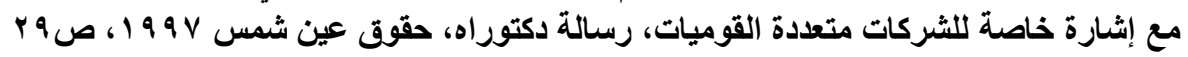

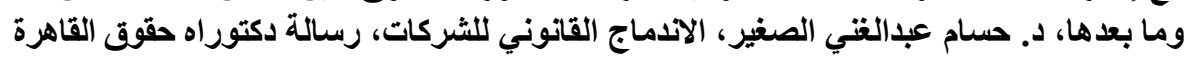

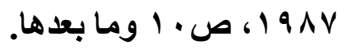


فتلـك النسبة في ذاتهـا كافيـة للتحكم في إدارة الشركة التابعـة، دون الحاجـة لنصوص في النظام الأساسي طالما أن القرارات تصدر عن تلاك الثركة بأغلبية أصوات

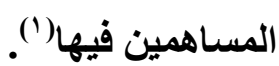

أما إذا كاتت الثركة تمتلك نسبة أقل من 1 \%\% من رأسمال شركة أخرى، فإنـه يجب التفرقة بين فرضين: الأول: إذا كان من بين اسهم تللك الشركة أسهم ممتازة بحيث

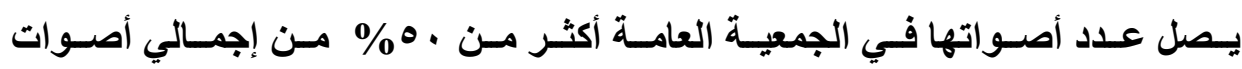

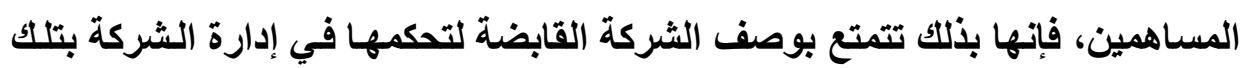
النسبة(؟)، والثانى: إذا كاتت كل هذه الأسهم عادية، فهنا لا تكفي الأغلبية التي تقل عن الته • \% \% لإسباغ وصف القابضة على الشركة لعدم تمتعها بسلطة السيطرة على إدارة

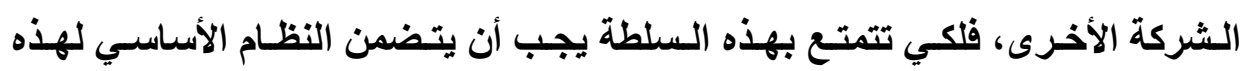
الثركة نصاً يعطي الشركة الأولى الحق في تعيين وعزل أعضاء مجلس إدارة الشركة الثانية، أو يعتبر أعضاء مجلس إدارة الشركة القابضة ـ كلهم أو معظمهم - أعضاء أيضاً في مجلس إدارة الشركة التابعة. وعادة ما ينشأ هذا الوضع في حالة مـا إذا كانت الشركة القابضة مالكة لبر اءوة اختراع، ورخصت للشركة التابعة باستعمالها بشرط أن يكون لها حق السيطرة على لهى إدارتها.

(1) Claude CHAMPAUD. Le pouvoir de concentration de la societé - par action, Librairie sirey, Paris 1962. p. 243 : 317.

(2) Pennington's company law 2nd. Ed. London 1967, p. 583.

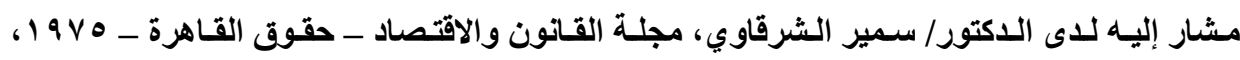

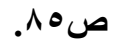


أو يبرم اتفاق بين الثركة القابضة ومساهمين آخرين تكتمل بهم أغلبية 1ه\% من رأسمال الشركة التابعة، يلتزم بمقتضاه هؤلاء المساهمون بالتصويت مـع الشركة القابضة في القرارات التي تتخذها الثركة التابعة.

r - وجود نص في القانون يعطي الثركة القابضة حق التحكم في إدارة الثركة التابعة، أياً كاتت نسبة الأسهم التي تمتلكها الثركة القابضة في رأسمال الشركة التابعة.

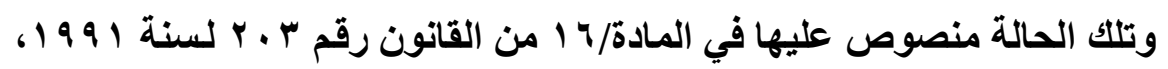
حيث أعطت هذه المادة لرئيس مجلس الوزراء سلطة إصدار قرار بتحديد الشركة

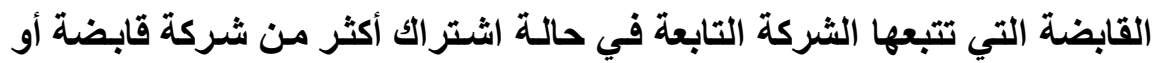

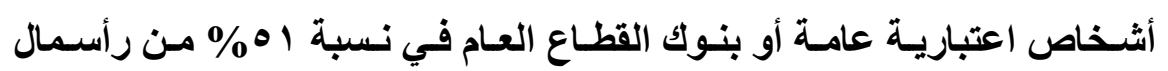

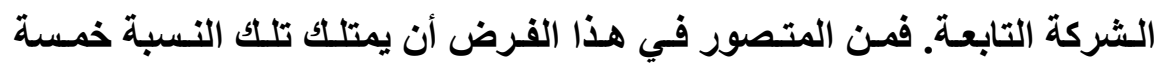

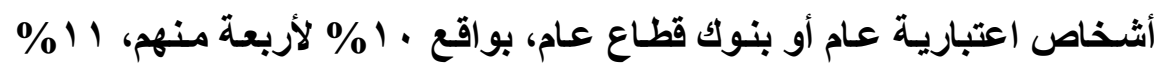
للخـامس مثثلا. فهنـا يختـار رئسيس الوزراء أحد هؤلاء الأثـخاص ليكون بمثابـة

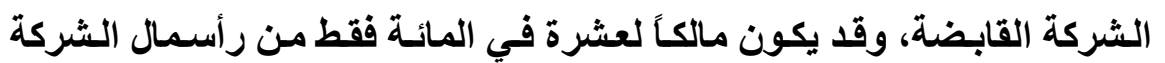
التابعة. فسيطرة الشركة القابضة ـ في هذا الفرض ـ على إدارة الشركة التابعة تجد مصدرها في قرار مجلس الوزراء الأي يستند على نص في القانون. وهناك حالة أخرى تكون فيها الثركة قابضة رغم عدم تملكها في الشركة التابعة لنسبة 10

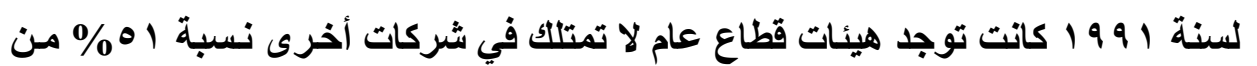
رأس المال، ومع ذلك كاتت هذه الثركات من شركات القطاع العام التي تخضع للقانون

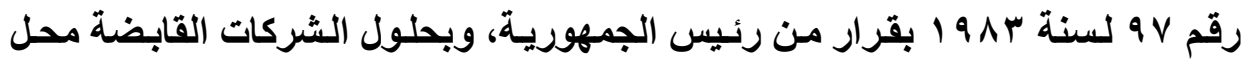
هذه الهيئات والشركات التابعة محل شركات القطاع العام كأثر لصدور القانون رقم

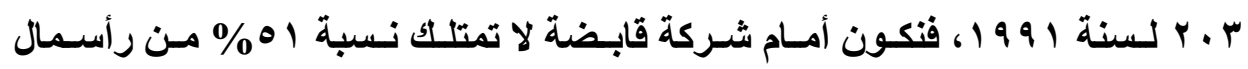


الثركة التابعة. وهكذا فإن القانون هو مصدر تمتع الثركة القابضة بحق السيطرة على

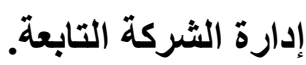

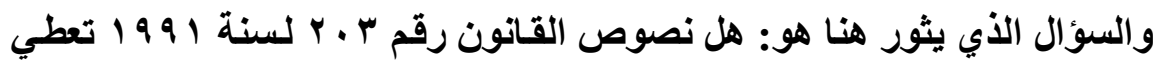

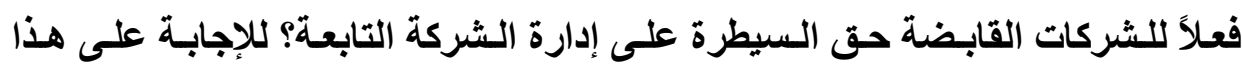
التساؤل يجب التفرقة بين الفرضين الآتيين:

(1) إذا كانت الثركة القابضة تمتلك 10 \% من رأسمال الشركة التابعة، فإنها تتمتع

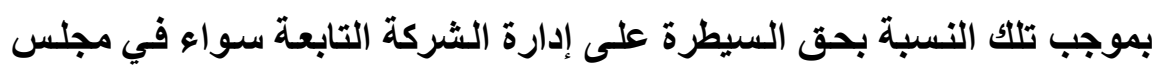

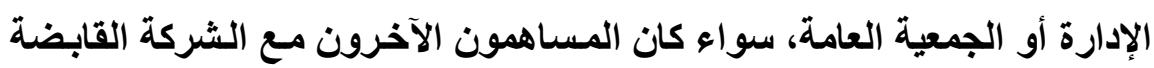

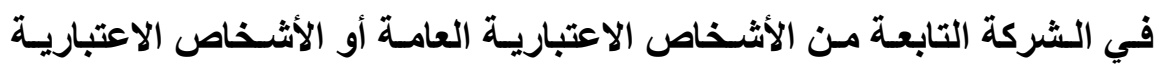

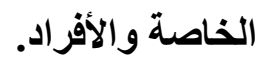

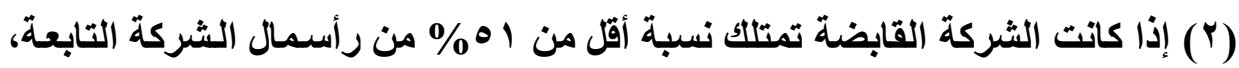
فيجب التفرقة بين نوعين من الثركات التابعة:

أ ـ الثركة التابعة التي يمتلك رأسمالها الثركة القابضة بالاثتراك مع شركات

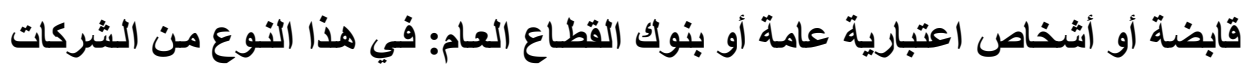

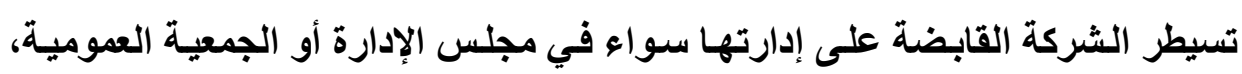

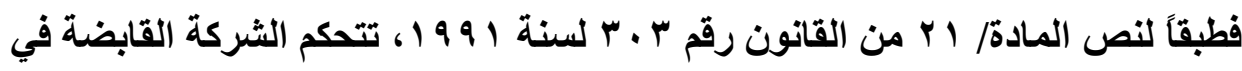

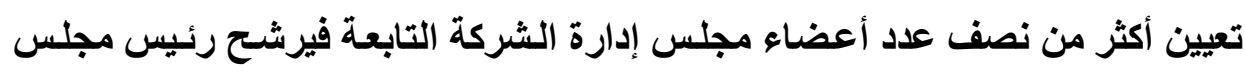

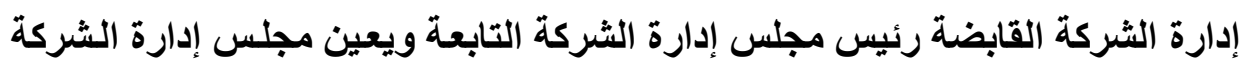
القابضة نصف عدد أعضاء مجلس إدارة الثركة التابعة. وفي الجمعية العمومية لتلك الشركات التابعة، تكون الأغلبية للشركة القابضة،

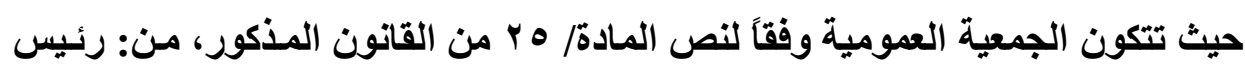


الثركة القابضة (رئيساً) وعضوية أعضاء مجلس إدارة الثركة القابضة، وعدد أربعة أعضاء بحد أقصى تختارهم الجمعية العمومية للشركة القابضة. بـ الشركة التابعة التي يساهم في رأسـمالها أفراد أو أشـخاص اعتباريـة مـن القطاع الخاص: إن نصوص القانون رقم ب • ب لسنة 1991 المتعلقة بإدارة هذا النوع من الشركات قد لا تكفل للشركة القابضة سلطة السبطرة على إدارة الشركة التابعة،

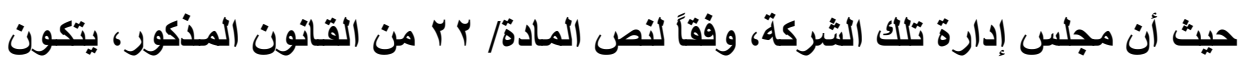

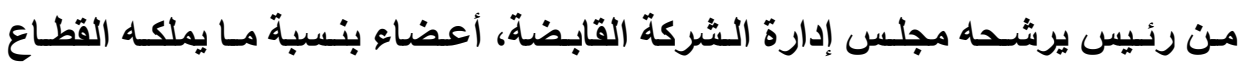
الخاص يختار هم ممثلو هذا القطاع، وأعضاء غير متفرغين يتم انتخـابهم من العاملين

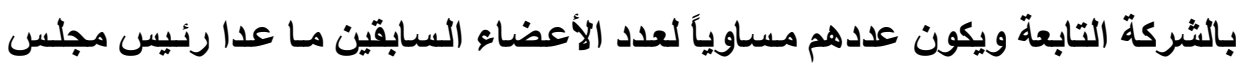
الإدارة. وعلى ذلك لو فرضنا أن عدد الأعضاء من ذوي الخبرة أربعة، وعدد أعضاء أعضاء ممثلي القطاع الخاص أربعة، فإن عدد الأعضاء الذين ينتخبهم العاملين يكون ثمانية،

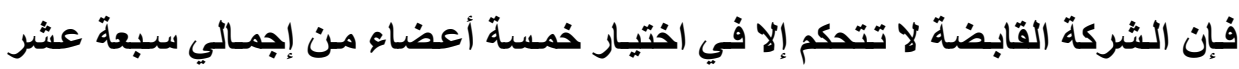
عضواً.

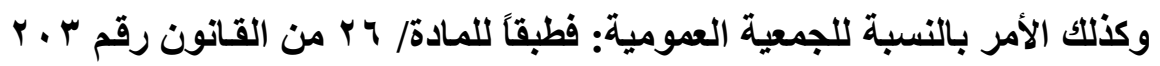

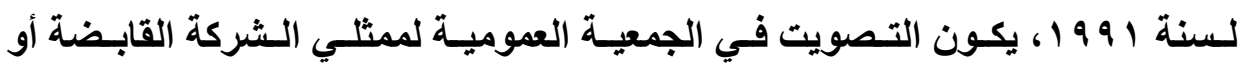

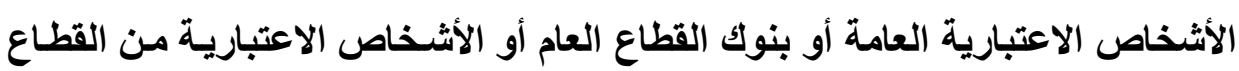

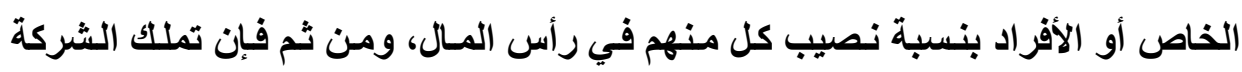
القابضة بنسبة أقل من 1 \%\% في رأسمال الشركة التابعة في هذا الفرض لا يعطيها الأغلبية في التصويت في الجمعية العمومية. وعلى ذلـك، فـإن الشركات التـي لا تمتلك 1 \% \% مـن رأسـمال شـركات أخرى،

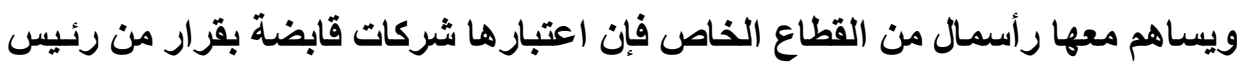

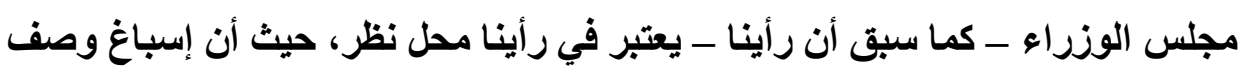


القابضة على شركة ما يستلزم سيطرتها على إدارة الثركة التابعة لها، وهو الأمر الأي لا يتوافر للشركات المشار إليها.

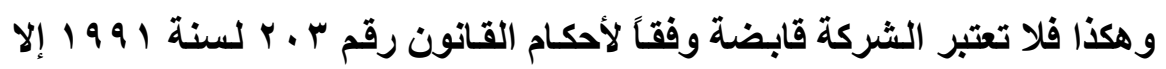
في الحالتين الآتيتين: أ - إذا تملكت نسبة 1 \% من رأسمال شركة أخرى، سواء بالمساهمة مـع القطاع الخاص أو الأشخاص الاعتبارية العامة أو بنوك القطاع العام. ب - إذا تملكت نسبة من 1 \%\% من رأسمال شركة أخرى، إذا كان المساهمين الآخرين

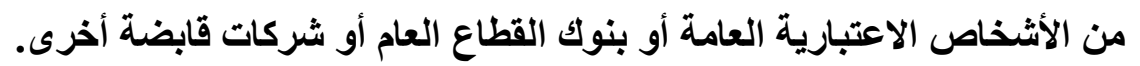
وخلاصة القول أن تحكم الشركة القابضة في إدارة الشركة التابعة يجد مصدره

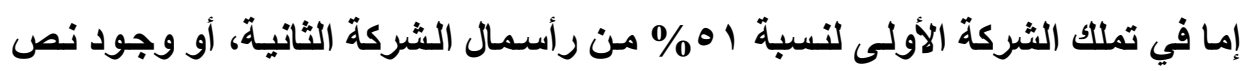
في النظام الأساسي للشركة الثانية أو اتفـاق بين الشركة القابضة وبعض الثض المساهمين الآخرين، أو وجود نص في القانون.

\section{الفرع الثاني}

\section{الارتباط عن طريق التجمع الموقتت}

\section{Consortium (الكونسورتيوم)}

قد ترتبط الشركات بعضها ببعض عن طريق ما يسمى اتحساد الشركات أو التجمع المؤقت للشركات (الكونسورتيوم). وهذا اللفظ ليس عربياً وإنمسا لاتينيا، وينشأ هذا التجمع بين الشركات غالباً لتففيذ عقد إداري لصالح جهة الإدارة، فقد يكون محل هذا العقد مشروع ضـخم لا تسنطيع شـركة واحدة تنفيذه، فتقوم مجموعة من الشركات المتخصصة في مجال محل هذا العقد بتكوين تآلف فيما بينهم يسمى باتحاد الشركات أو أو

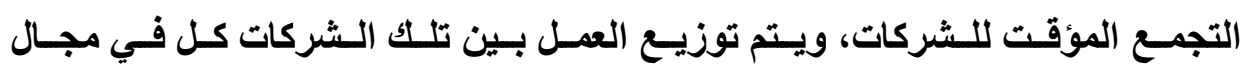


اختصاصها. وتقدم كل شركة مـا لـديها من خبراء فنيـة وتكنولوجية متطورة في سبيل

$$
\text { تنفيذ المشروع. }
$$

وبيان المقصود بهذا التجمع أو الاتحاد (أولاً) يمكنتا من معرفة خصائصه (ثانياً)،

وطبيعته القانونية (ثالثاً) والوقوف على أوجه الثبه والاختلاف مـع غيره من الكيانـات

$$
\text { الأخرى (رابعاً). }
$$

$$
\text { أولاً: مفهوم التجمع المؤقت للشركات (الكونسورتيوم): }
$$

الكونسورتيوم هو اتفاق يبرم بين مجموعة من الأطراف محلية أو أجنبية، قـ

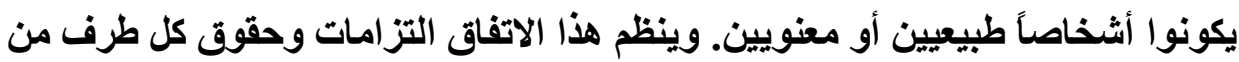
أطرافه في تنفيذ مشروع معين لصالح جهة إدارية، ويهدف أطراف الاتفاق إلى تحقيق

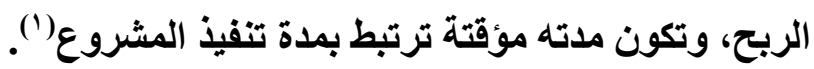

ولا ينشأ عن هذا العقد كيـان ذاتـي أو شخصية قانونية مستقلة عن الشركات

المكونة له، فكل من تلك الشركات تحتفظ بشخصيتها القانونية المستقلة.

ويهـف هذا التجمع إلى تسهيل تنفيذ المشروعات الضخمة، وتقسيم المخـاطر

الناتجة عن التنفيذ والحد من المنافسة بين أطرافه في الأسواق المحلية والدولية.

وقد تكون الثركات المكونة لهذا التجمع من جنسية واحدة أو من عدة جنسيات

مختلفة، وقد تكون من شركات القطاع العام أو الخاص أو كليهما.

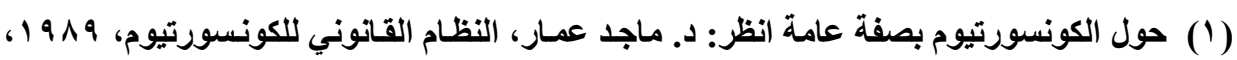

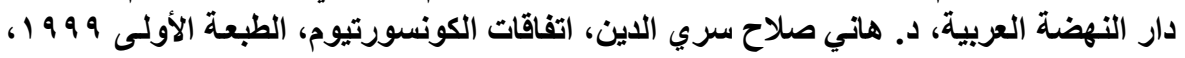

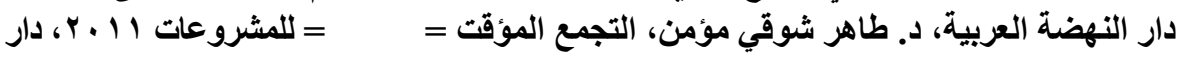

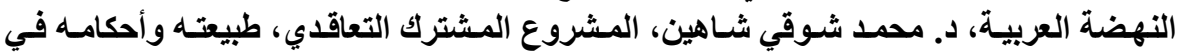

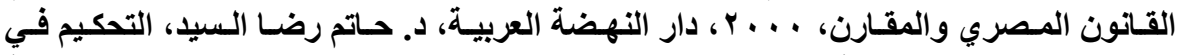

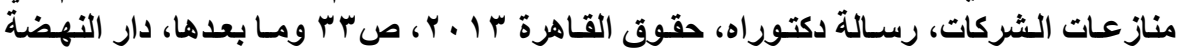


والكونسورتيوم على هذا النحو هو تجمع اقتصادي وقانوني ذات قدرة فائقة على

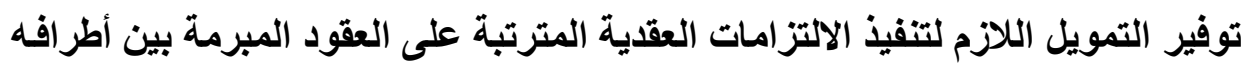
بعضهم ببعض، أو بين كل طرف مـن هذه الأطراف وجهة الإدارة، فـالتجمع المؤقت للشركات يشتمل على مجموعة عقود مرتبطة. وقد إزداد اللجوء إلى التجمع المؤقت في تنفيذ عقود الإنشاءات الدولية، حيث يعد أفضل صورة من صور التعاون في تنفيذ عقود الأثـغال العامـة، نظراً لأن هذه العقود الأن ليست من العقود ذات الأجل الطويل كعقد الالتزام. ثانياً: خصائص الكونسورتيوم وأنواعه:

من خلال التعريف السابق للكونسورتيوم يمكن استخلاص خصائصه التي تتمثل

$$
\text { فيما يأني: }
$$

1 - يتكون التجمع بموجب عقد إطار ومجموعة من العقود بداخله، تنظم التفاصيل الفنية والمالية والإدارية لتنفيذ المشروع المسند لهذا التجمع، وتشتلزم دقة تلك التفاصيل

$$
\text { وتشعبها أن تكون كل تلك العقود مكتوبة. }
$$

Y ـ نظراً لأن التجمع لا يتمتع بشخصية معنوية مستقلة، ومن ثم لا يستطيع إبرام العقود مع الغير ولا التعامل معه بشخصه، فإن الأمر في حاجة إلى تحديد شخص لخد يتعاقد

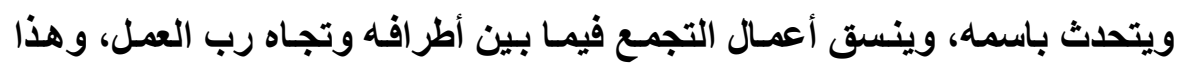

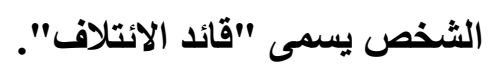

r- لا يتمتع التجمع بشخصية قانونية ولا بذمة مالية مستقلة.

$$
\text { ـ ـ ليس للتجمع رأسمال مشترك. }
$$

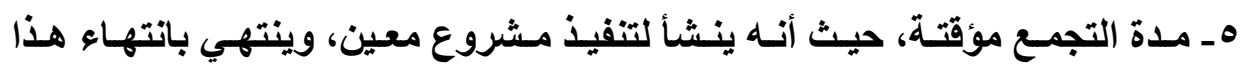

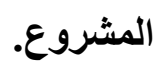

VY. مجلتّ البحوث القانونيت والإقتصاديتة 
أمسا عن أنسواع الكونسورتيوم فهي عديدة، ولكن مـا يهمنـا منهـا مـن الناحيـة

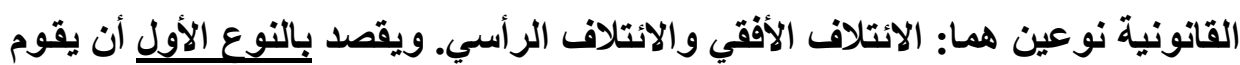

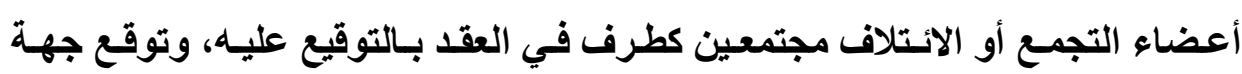

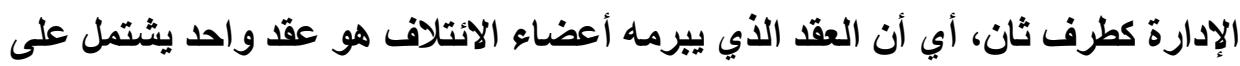

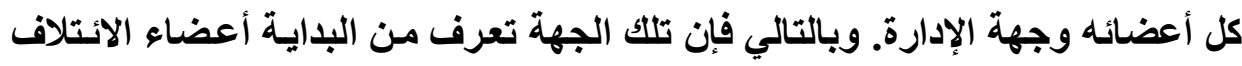

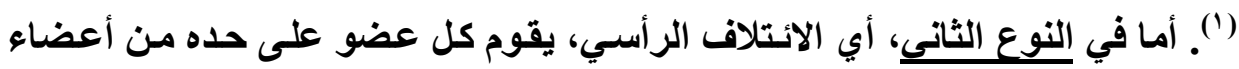

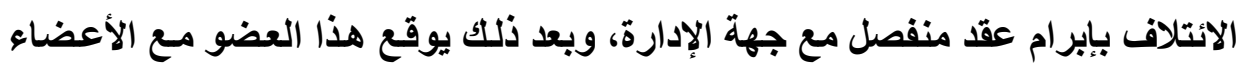

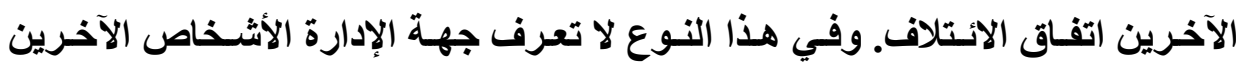

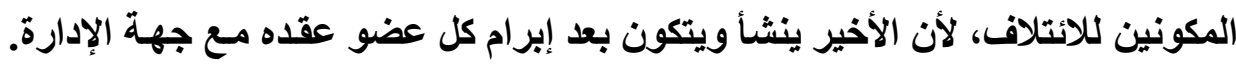
ولذلك فإن الاتتلاف الرأسي ليس ذائعاً في مجال العقود الدولية للإنشاءاتات. ثالثاً: الطبيعة القانونية للكونسورتيوم:

اختلف الآراء حول تحديد الطبيعة القانونية للكونسورتيوم. فذهب البعض إلى انهـ

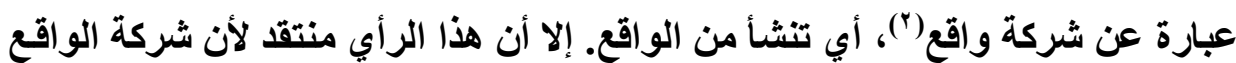

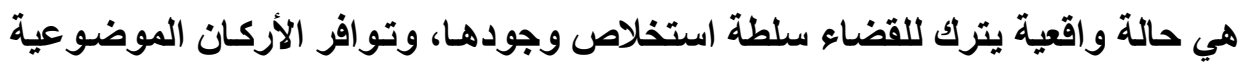

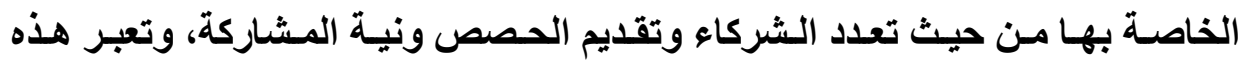
الثركة عن الوضع الذي يوجد فيه عدة أثخاص يتصرفون من حيث الواقع كمـا لو الو الو

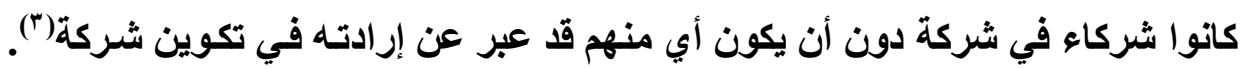

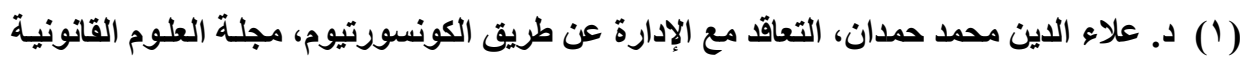

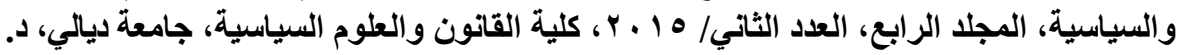

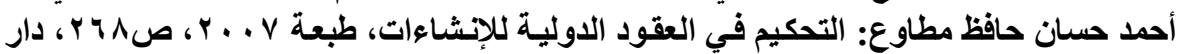
النهضة العربية. - مانية

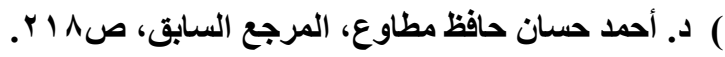

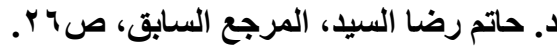


أما الوضع بالنسبة للكونسورتيوم مختلف، حيث لم يقلم أعضاؤه أية حصص، ولم تكن لايهم نية المشاركة، ومن ثم يفتقل الائتلاف لوصف شركة الواقع. وذهب رأي آخر إلـى أن الكونسورتيوم شـركة محاصـة لأنسه يقوم بعمل واحــ وبصورة مؤقتة وله مدير مسئول عن تنفيذ الأعمـال، وليس للمشروع اسم أو عندوان. وهذا الرأي بدوره منتقد، لأن مدير الكونسورتيوم يتصرف بصفته وكيلاً عنـه أمـا مدير

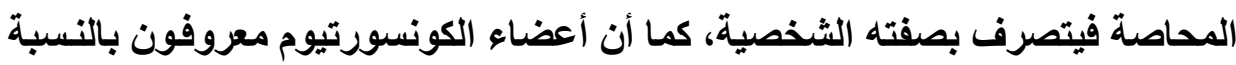
للغير أما شركة المحاصة فهي مستترة ولا يعلم عنها الغير شيئًا. ونحن نـرى أن الروابط العقدية في مجـال الكونسورتيوم نوعـان: النـوع الأول: العقد أو العقود التـي تبرم بـين أعضاء الكونسورتيوم مجتمعين أو أحدهم مـع جهـة الإدارة، وهذا العقد لا يثير خلافاً حول طبيعته، فهو عقد مقاولة أو عقد أشغال عامـة

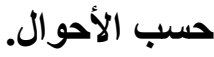

أما النوع الثانىي: فهو العقد الذي يبرم بين أعضاء الائتلاف. وأحكام هذا العقد تأبى تصنيفه ضمن العقود التقليدية كعقود الشركات لافتقاده مقومـات هذه العقود كمـا رأينا، ولذلك فنحن نرى أنسه عقد غير مسمى تحكمـه إرادة المتعاقدين بالدرجة الأولى نظراً لعدم تناول المشرع لله بـالتظيم كعقود البيع أو الإيجار أو الشركة أو غيرهـا من

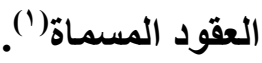
رابعاً: الفرق بين الكونسورتيوم وما يتشابه معه من الكيانات الأخرى: يتشابه الكونسورتيوم مع بعض الكيانات الأخرى من حيث عدم تمتعه بالشخصية

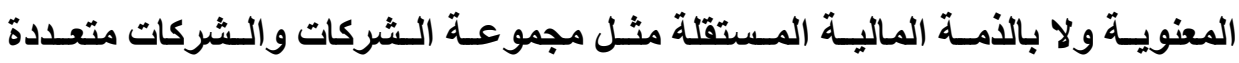


القوميات(') فوجه الثبه بين هذه الكيانات الثثلاثة أنها جميعاً لا تتمتع بثخصية معنوية مستقلة عن الأثخاص المكونة لها، وبالتالي فلا تتمتع بذمة مالية مستقلة. أما عن أوجه الاختلاف بين تلك الكيانات، فتتمثل في الآتي: ا- أن الارتبـاط بين مجموعـة الشركات يجد مصدره في تملك الشركة القابضة أو

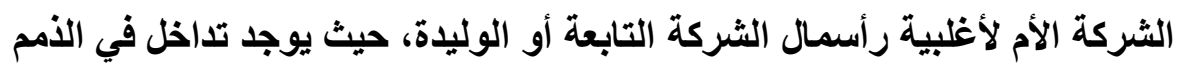

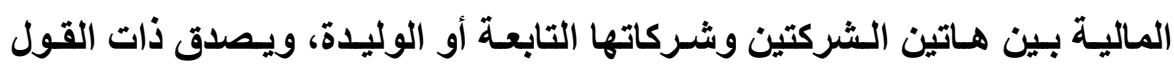

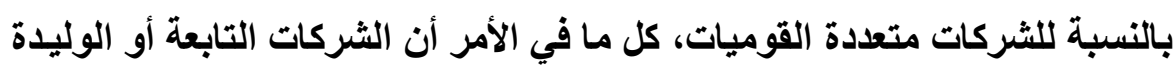

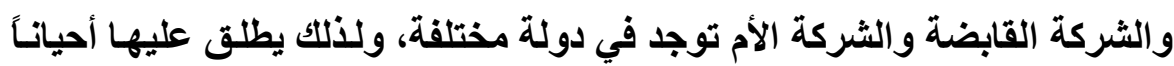
"الثركات عبر الدود"، أما مجموعة الشركات فكل الثركات التي تنتمي إليها

$$
\text { توجد في دول واحدة. }
$$

r ـ أما ارتباط الثركات في الكونسورتيوم فيجد مصدره في عقد الاتتلاف المبرم بين

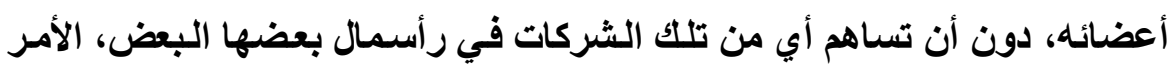

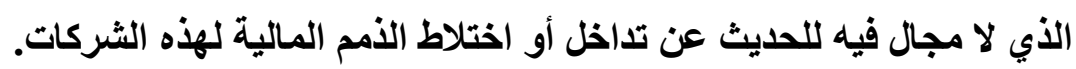

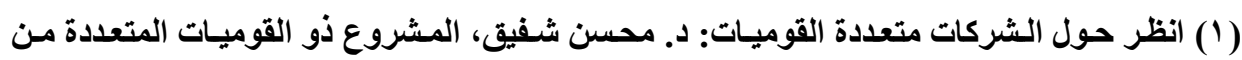

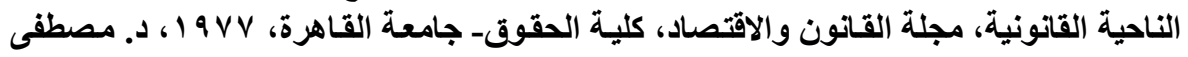

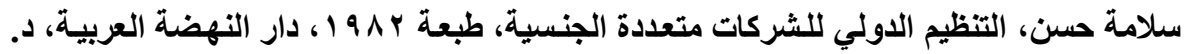

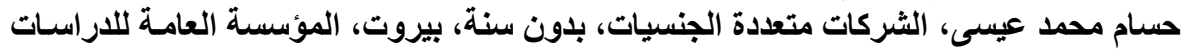

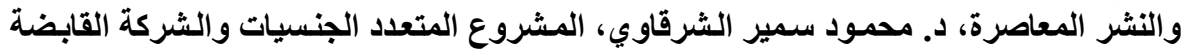

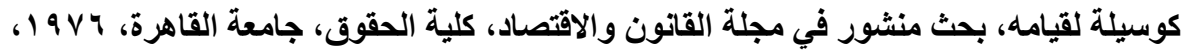

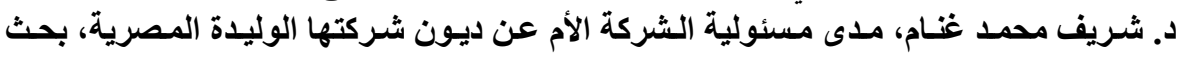

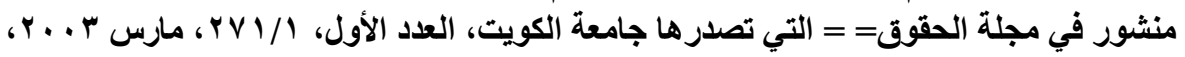

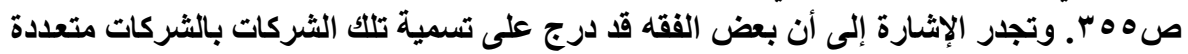

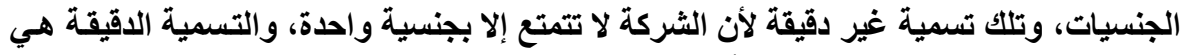

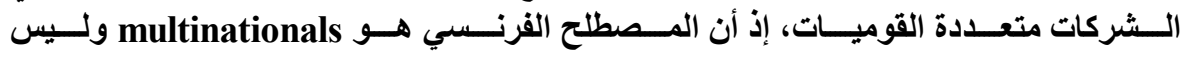
.multnationalités 


\section{المطلب الثاني}

\section{أثر الارتباط على الذهة المالية}

\section{لالشركات المرتبطة}

يختلف أثر الارتبـاط على الذمـة الماليـة للشركات المرتبطة بحسب مـا إذا كـان الارتبـاط في شـل مجموعة شـركات (الفرع الأول) أو في شكل تجمـع مؤقت (الفرع الثاني).

\section{الفرع الأول}

\section{أثر الارتباط في حالة هجموعة الشركات}

إن مـا يميز مجموعة الشركات عن غيرهـا من تجمعـات الشركات الأخرى مثل

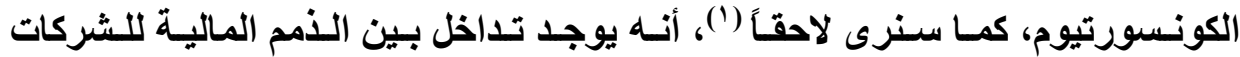
المنتمية لتلك المجموعة. ويرجع مصدر هذا التداخل والارتباط بين ذمم تلكك الشركات إلى خضوعها لسيطرة شـركة تسمى الشركة القابضة أو الشركة الأم، وأسـاس تلكـ السبطرة هو تملك أي من هاتين الثركتين أغلبية رأسمال الثركات التابعة أو الشركات الوليدة، أو وجود نص في القانون يمنحهمـا تلك السيطرة، كمـا هو الحسال في قانون

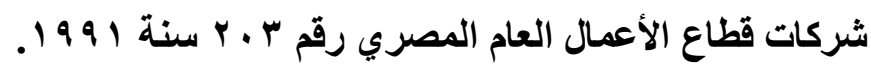
وهذا التداخل والارتباط بين الأمم المالية للشركات المنتميـة لمجموعة الشركات يمثل تركيزاً اقتصادياً في صورة أن المركز المسيطر على تلك الشركات، سواء في في تحديد سياساتها الاقتصادية أو الأهداف التي ترمي إلى تحقيقها، هو الثركة القابضة أو أو الثريزي الثركة الأم، فهي التي تعمل على توحيد القرار بالنسبة لهذه الشركات. فهذا التركيز 
الاقتصادي يهذف في النهاية إلى توحيد الوجهة الاقتصادية للشركات المذكورة. فهناك تبعية اقتصادية بين الثركة القابضة وشركاتها التابعة والثركة الأم وشركاتها الوليدة،

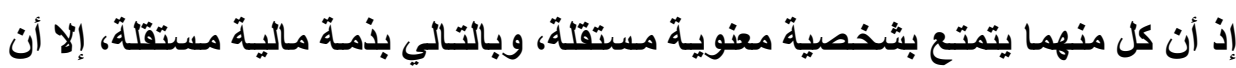

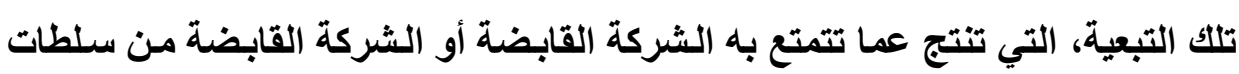

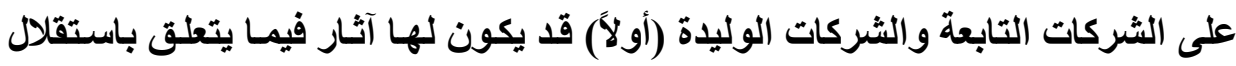

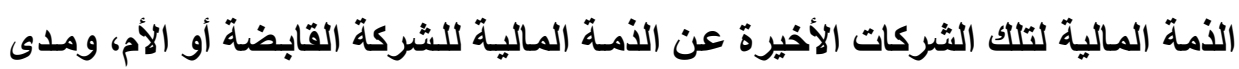

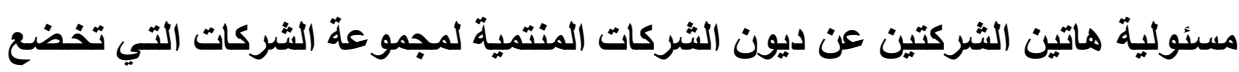

$$
\text { لسيطرة أي منهما (ثانياً). }
$$

(أولاً) أوجه التبعية بين الثركة القابضة أو الثركة الأم والثركات التابعة أو الوليدة:

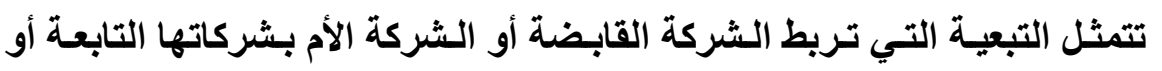

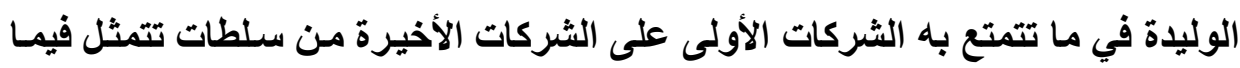
يلي:

1- تملك الثركة القابضة أو الثركة الأم سلطة اتخاذ القرار الذي يحقق المصلحة

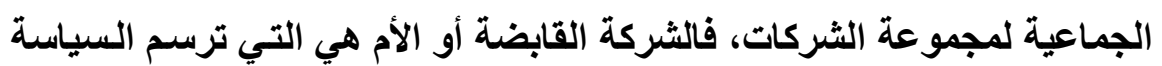

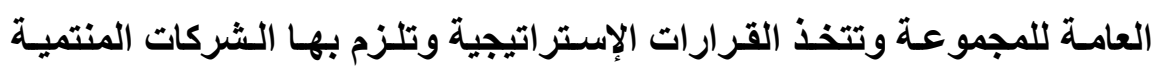

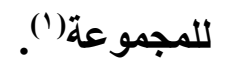
r ـ تمارس الثركة القابضة أو الأم حق الرقابة و التوجيه على الشركات التابعة أو الوليدة في إطار تحقيق أهداف مجموعة الثركات. 
rـ تعد الثركة القابضة أو الثركة الأم القوائم الماليـة المجمعة لمجموعة الشركات

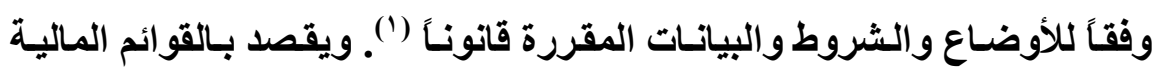

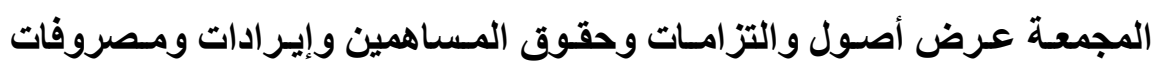

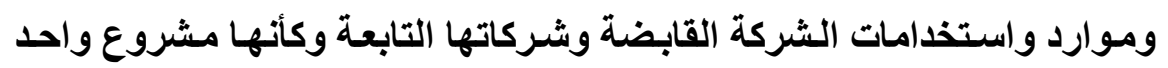
دون النظر إلى الحدود القانونية بين الوحدات المختلفة، بما يكفل بيان الإمكانيات الاقتصادية للمجموعة ككل، وكذلك هيكل الملكية.

ع- تقوم الثركة القابضة بكافة الأعمال اللازمة لتصحيح الهياكل التمويلية ومسار

الشركات المتعثرة التابعة لها وتعظيم ربحية هذه الثركات وترشيد التكلفة(؟).

هـ تتدخل الشركة القابضة في اختيار أعضاء مجلس إدارة الشركة التابعة (").

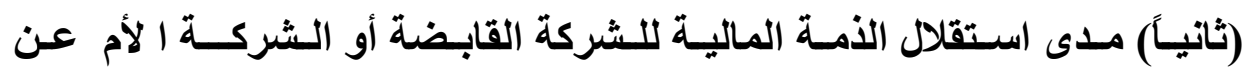

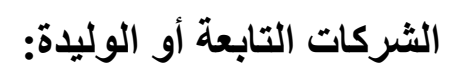

تعتبر الشركة القابـة أحلد مسـاهمي الشركة التابعة إذا كانـت تمتلكـ أغلبيـة

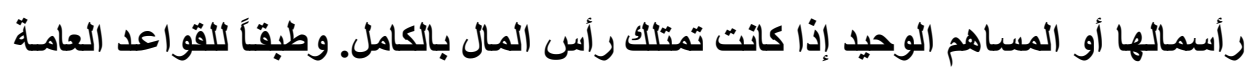

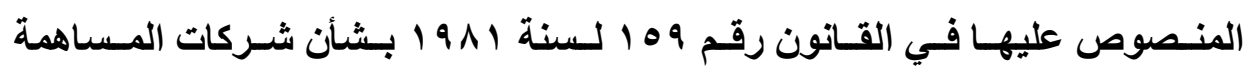
والتوصية بالأسـهم والشركات ذات المسئولية المحدودة، تكون مسئولية المساهم في

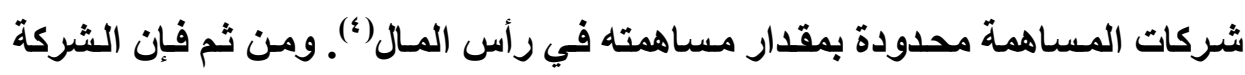

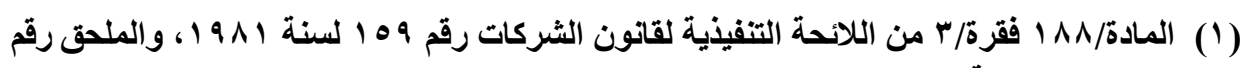
ه من تلك اللائحة.

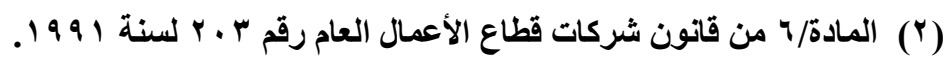

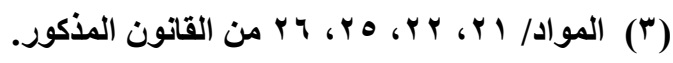

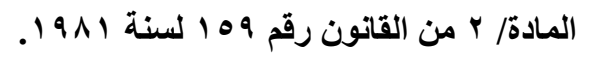


القابضة لا تسأل عن تصرفات الشركة التابعة بحسب الأصل إلا بمقدار مساهمتها في رأسمالها.

إلا أن تطبيق هذه القواعد العامة في مجال الشركات القابضة والشركات التابعة

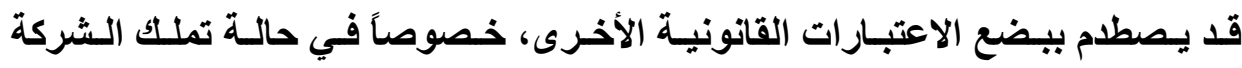
القابضة لكامل رأسمال الثركة التابعة، وكذلك إذا أخذنا في الاعتبار أن الشركة القابضة الإهة هي التي تسيطر على إدارة الثركة التابعة. فبإذا كانـت الشركة القابـضة تمتلـك أغلبيـة رأسـمال الـشركة التابعة، فبجانـب

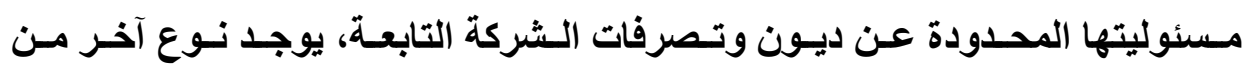
المسئولية يمكن أن تنعقد إذا ثبث أن الثركة القابضة، التي تدير الثركة التابعة بما لها A bus de من أغلبية في رأسمالها، قد ارتكبت تعسفاً في ممارسة سلطاتها في الإدارة Contrôle مصالح شخصية لبعض المساهمين، أو أن الشركة القابضة كانـت تهـف مسن وراء إدارتها إلى تحقيق مصالحها فقط في الشركة التابعة على حساب مصالح المساهمين

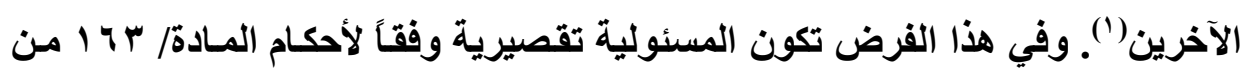
القانون المدني. والأصل أن الثركة تعتبر عقد بين شريكين أو أكثر (). كمـا أن القانون المصري

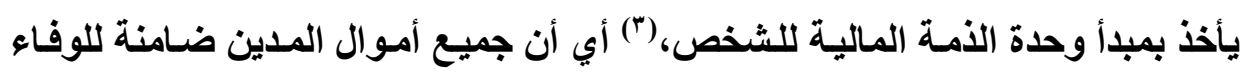
(1) (1) NIOREL, la societé anonyme devant la jurisprudence moderne, Thése Nancy p. 245; CL CHAMPAUD, op cit. P. 145, M 161.

$$
\begin{aligned}
& \text { المادة/ هـ ـ ه من القانون المدني. } \\
& \text { المادة/ ؛ ؟ ب من القانون المدني. }
\end{aligned}
$$


بديونه، ولا يستطيع بالتالي تخصيص جزء من هذه الأمة لاستثمار ها في نشاط معين،

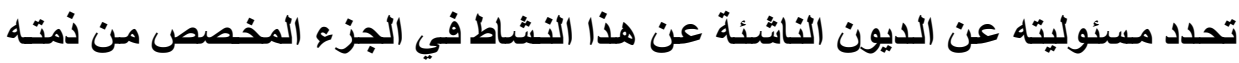
المالية له دون أن تمتد إلى بقية أمواله. وهذا المبدأ يمثل، في حقيقة الواقع، عقبة أمسام مباشرة التجارة حيث أن الشخص الذي يرغب في استغلال جزء من أمواله لمباشرة نشاط بمفرده، يخشى من تعرضه لشهر الإفلاس نتيجة توقفه عن سداد الديون المتعلقة

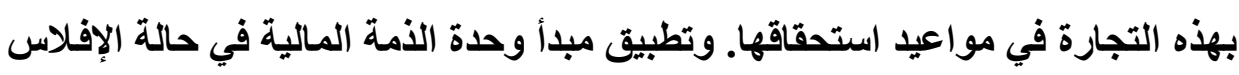
قد يعصف بذمة التاجر المالية بالكامل، ويصبح النشاط التجاري وبالاً عليه ('). لذلك تتجه معظم التشريعات الحديثة نحو الاعتراف للتجار بتخصيص أجزاء من أموالهم لمباثرة نشاط تجـاري معين وتحديد مسئوليته عن هذا النشاط في الأموال

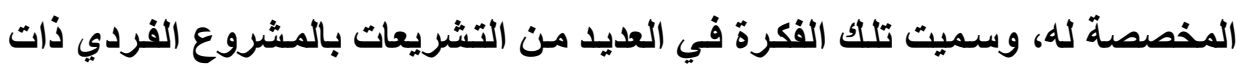
المسئولية المحدودة L'enterprise personnelle à responabilité Limitée. وتتبع هذه التشريعات أحد طريقين لتحديد المسئولية عن الديون الناشئة عن

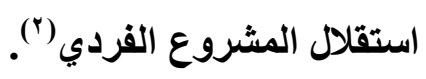

- إمـا إدخـال المشروع الفـردي ذات المسئولية المحدودة في هيئة ذمـة ماليـة متخصصة La patrimoine d'affectation. أي الاعتراف لهذا المشروع بذمـة مالية منفصلة عن الامة المالية الخاصة بصاحبه، بحيث يقتصر ضمان دائني المشروع

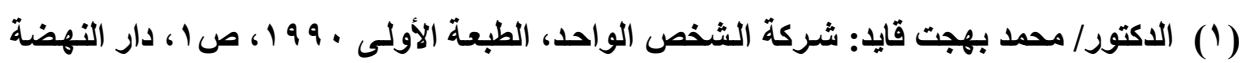

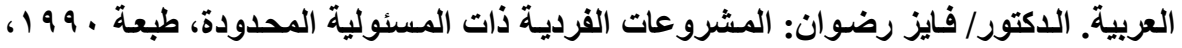

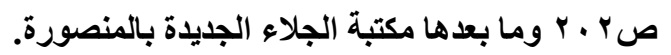

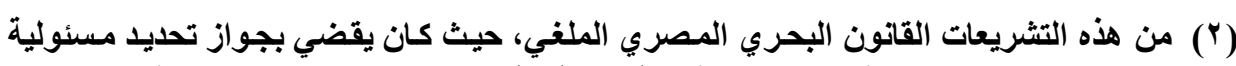

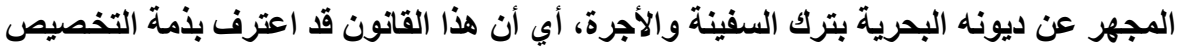

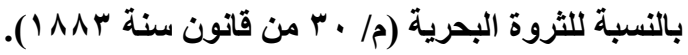


على الذمة المالية المخصصة لاستثماره، وهذا الطريق يغتي عن الاعتراف للمشروع الفردي بالثخصية المعنوية La personalité morale

- إما تأسيس المشروع الفردي ذات المسئولية المحدودة في شكل شركة فردية Une Societé unipersonnelle

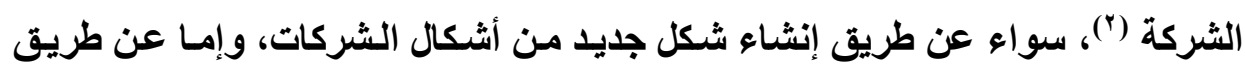
ملاعمة نظام الشركة الفردية مع القواعد المتعلقة بشركات المساهمة أو بالشركة ذات المسئولية المحدودة. وقد اتبع المشرع المصري في القانون رقم ب • ب لسنة الو9 19 الطريق الثاني، حيث اعترف للشركة التابعة المملوكة بالكامـل للشركة القابضة بالشخصية القانونية

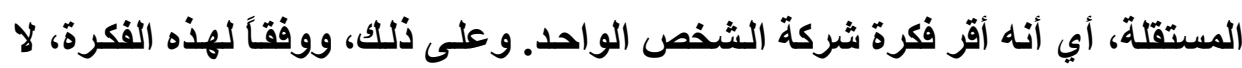

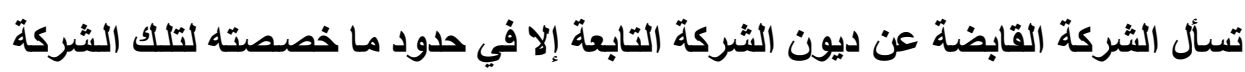

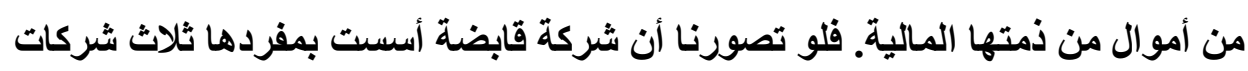

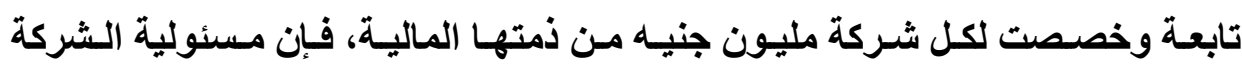

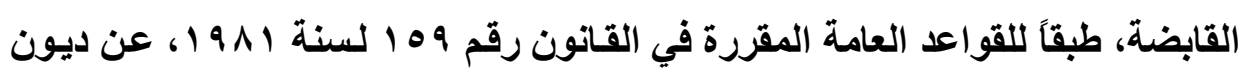
كل من تلك الشركات الثُلاث تكون في حدود مليون جنيه فقط (")، ولا يجوز لدائني أي منها التففيذ على أموال الثركة القابضة في الشركات المملوكة لها الأخرى بـأكثر من فن فئن هذا المبلغ، بحيث إذا لم يكف رأسمال الشركة التابعة للوفاء بكل ديونها وتوقفت عن

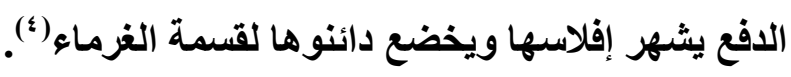

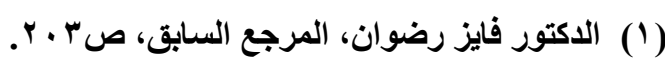

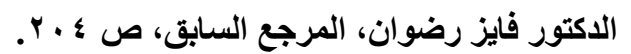

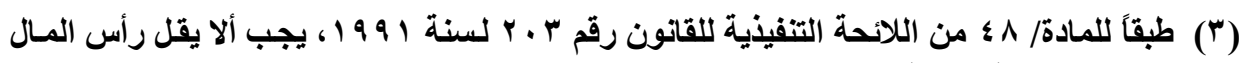
المصدر للشركة التابعة عن مليون جنيه.

$$
\text { انظر سابقاً ص س با } 19 \text { وما بعدها. }
$$


ولكن إذا كـان تطبيتق هذه الأحكـام على شـركات المسـاهمة بشكل عـام لا يثير صعوبات تـكر، فـإن الأمسر لا يسير على هذا النحو مـن البساطة إذا تعلق بمسئولية

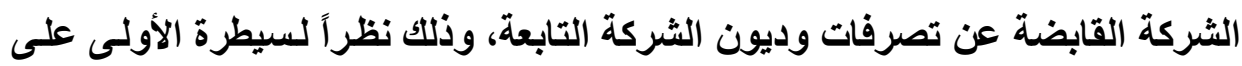
إدارة الثانية. فالثركة القابضة هي التي تقوم على إدارة الشركة التابعة. فإذا ثبت أن

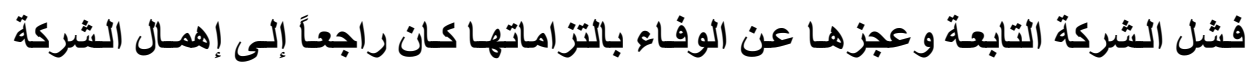

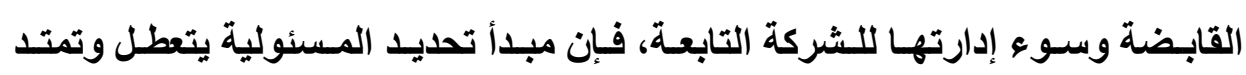

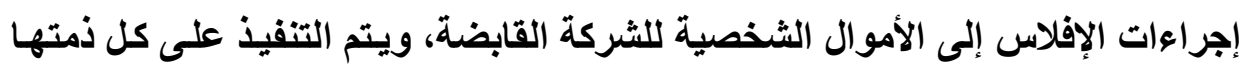

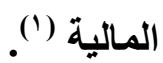
وكذلك قد تسأل الشركة القابضة مسئولية كاملة عن ديون الشركة التابعة في

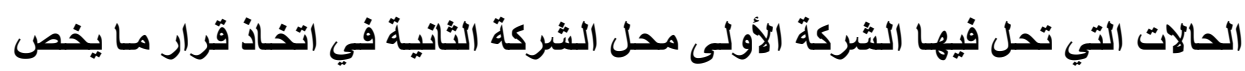

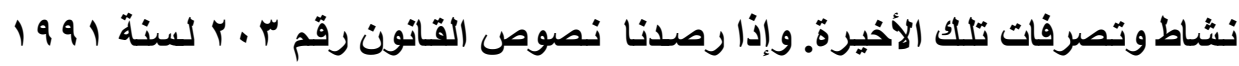

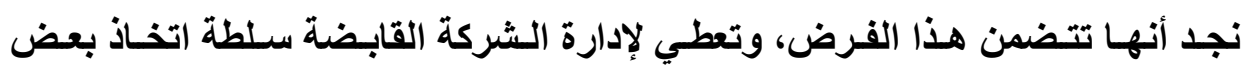

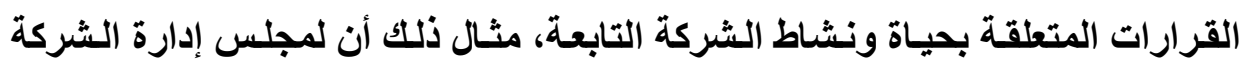
القابضة حق القيام بكافة الأعمال اللازمة لتصحيح الهياكل التمويلية، ومسار الشركات المتعثرة التابعة لها، وتعظيم ربحية هذه الشركات وترشيد التكلفة(؟). وكذلك فإن لمجلس إدارة الشركة القابضة سلطة القرار المناسب بشأن كل من: - - قوائم نتائج الأعمال والقوائم المالية الأخرى السنوية للشركات التابعة وتقارير مراقبي الحسابات.

- CL. CHAMPAUD. Op. cit. p. 280; - VERDIER filiales et participation fasc. 165 bis du traité jurisclasseur des societés. 


$$
\text { - مؤشرات الاستثمار في الثركات التابعة. }
$$

- الدراسات التي تعد لتصحيح مسار الشركات التابعة ومقترحات تصحيح المسار. ففي مثل هذه الفروض فإن القرار الخـاص بالشركة التابعة لا يصدر من مجلس

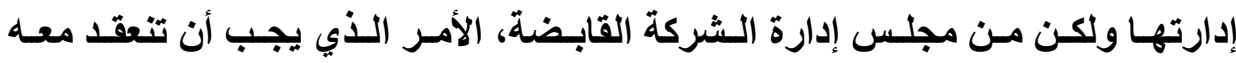
المسئولية الكاملة للشركة القابضة عن أعمال الثركة التابعة. فنحن هنا أمام وحدة في التهاره الإدارة بالنسبة للشركتين. Unité de direction وكذلك فإن تأسيس الشركة القابضة بمفردها لمجموعة شركات تابعة قد يؤدي في بعض الأحيان إلى الخلط بين الأمم المالية لهذه الثركات الأمر الذي يعطي دائني إحداها حق التنفيذ على أموال الثركات الأخرى. وقد ذهب القضاء الفرنسي إلى هذا المعنى حيث أعطى لموظف إحدى الشركات التابعة حق التنفيذ على الذمم المالية لكل هذه الثركات نظراً للخلط بين تلكك الذمم. واستخلصت المحكمة هذا الخلط من واقعة أن كل شركة من تلك الشركات لا تتخذ مقراً أو مركز

مستقلاً لإدارتها.

وجدير بالذكر أن حدوث الخلط بين الذمم الماليـة للشركات التابعة مـن ناحية والأمة المالية للثركة القابضة التي يتبعونها من ناحية أخرى، أكثر احتمالاً في القانون

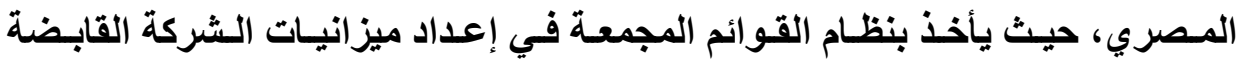
والشركات التابعة لها. وبعيداً عن هذا الوضـع، هنـاك عدة تطبيقـات قضائية في القضاء المقارن في خصوص استقلال الذمـة المالية للشركة القابضة عن الذمم المالية لشركاتها التابعة، نـذكر منهـا أربعة تطبيقـات إحداها في القضاء الأردنسي والثاني في القضاء القرنسي والثالث في أحكام محكمة العدالة التابعة للسوق الأوربية المشتركة، والرابع في القضاء الأمريكي. 


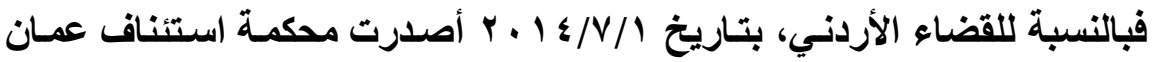

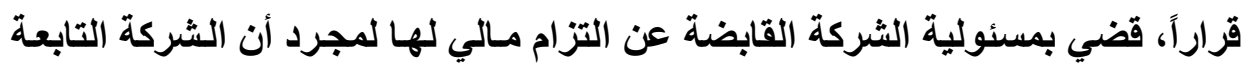
مملوكة بالكامل للثركة الأم، في هذه القضية قامت شركة القبس للتطوير العقاري ذات الترات

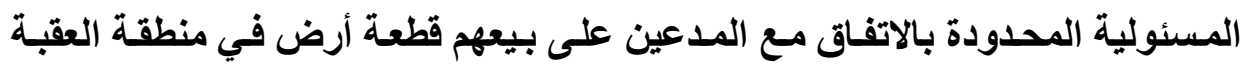

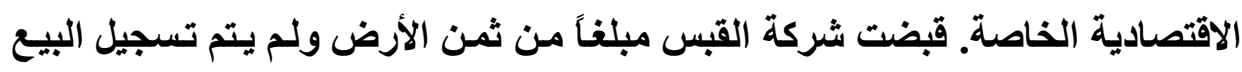

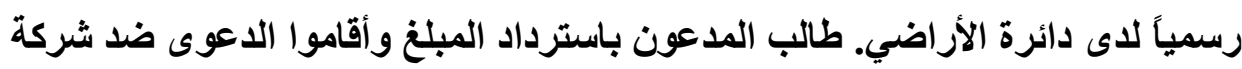
القبس وأيضاً ضد شركة تعمير الأردن القابضة على أساس أن شركة القبس تابعة لها. تمسكت شركة تعمير باستقلال شخصيتها القانونية وبالتالي ذمتها المالية. إلا أن

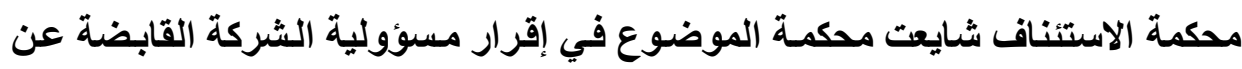

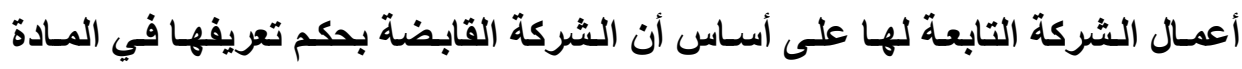
؟ ـ r من قانون الشركات تملك وتدير شركات تابعة لها. كما استدلت محكمة الاستئناف

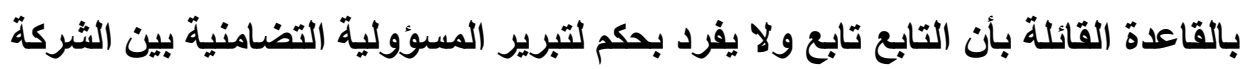
القابضة والثركة التابعة المدعي عليهما. طعت الشركتان المدعي عليهما في قرار محكمة الاستئناف متمسكتين باستقلال

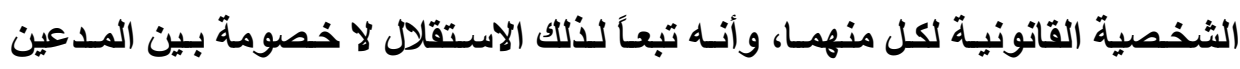

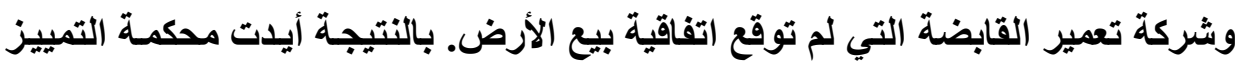

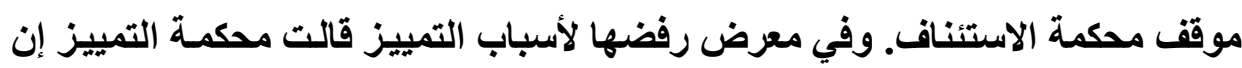

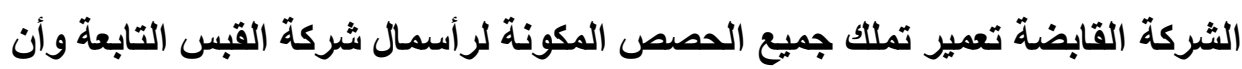

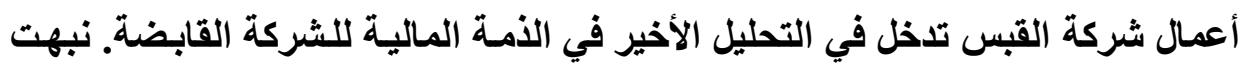

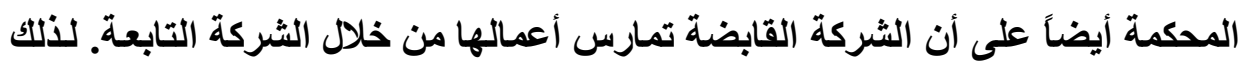

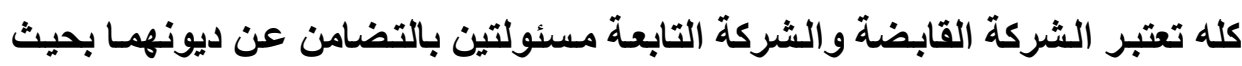


تكون الثركة القابضة مسؤولية عن أعمال الثركة التابعة وتسأل الشركة التابعة عن أعمال الشركة القابضة(')

وقد اتجهت محكمة العدالة التابعة للسوق الأوربية المشتركة إلى تقرير مسئولية

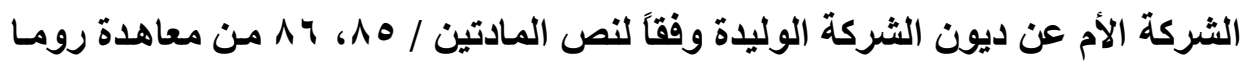

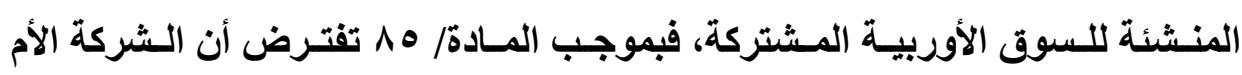
تشارك بنسبة رأسمال الشركة التابعة الموجودة في إحدى دول السوق الأوربية. وهذه

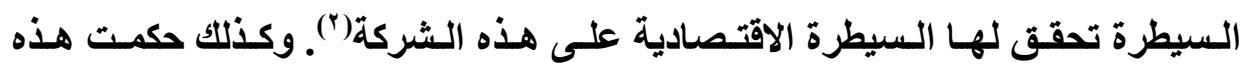

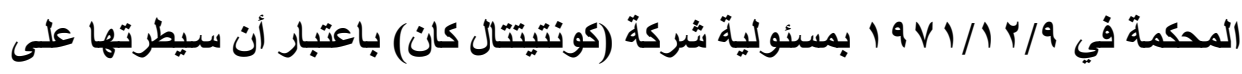

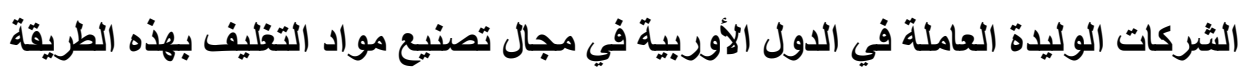
يشكل استثماراً تعسفياً في استعمال الوضع المسيطر (َ). وقد عرض هذا الموضوع على القضاء الفرنسي في قضية شركة مساهمة حصلت على عقد من البلاية باستغلال حمامات معدنية وفنادق. تم إنشاء ثُلاث شركات تابعة. أفلست الشركة الأم فطالب السنديك (وكيل التفليسة) بمد إفلاسها إلى شركتين من الشركات التابعة. وكان من وقائع الدعوى ما يكشف عن صورية هذه الشركات، منها أن مدير الشركة الأم عين مديرين الشركة التابعة وكانت إدارة الشركات كلها في ذات التهن المدينة التي بها إدارة الشركة الأم ولهم جميعاً إدارة حسابات وخزينة واحدة، وبالتالي

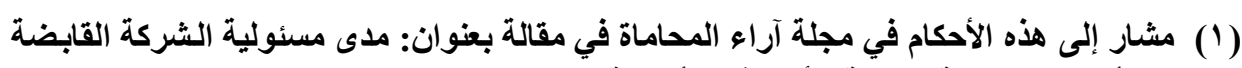

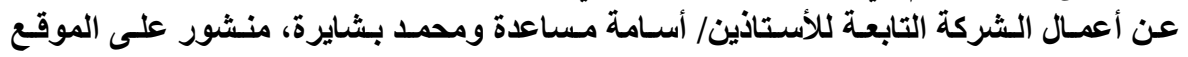
الاكتروني dictaconsulting.com./coporateveil (Y) هذا الحكم مشار إليه لاى د. د. هند محمد حسن، النظام القانوني للشركات متعددة الجنسيات، طبعة

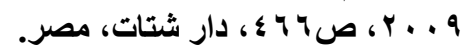

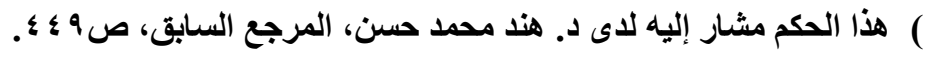


حكمـت محكمـة اكس الفرنسـية بمـــ الإفـلاس للـشركتين التـابعتين وأيــتها محكمـة

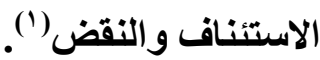
كما ذهب جانب من أحكام القضاء الأمريكي هذا الاتجـاه وقرر مسؤولية الشركة

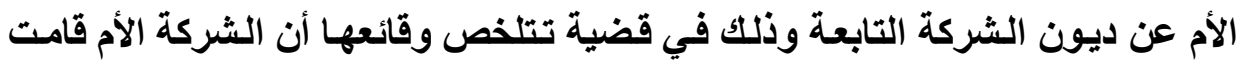

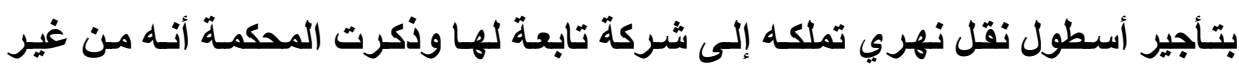

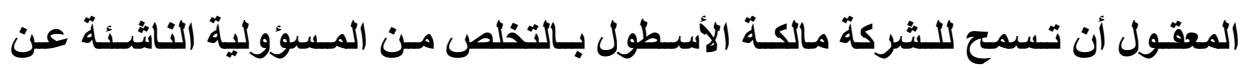

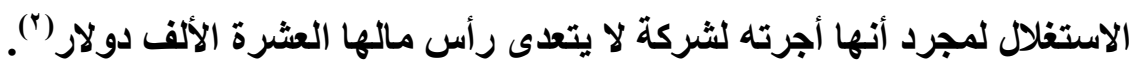

\section{الفرع الثثاني}

\section{أثر الارتباط على استقلال الذهم المالية}

\section{في حالة التجمه المؤقت}

ذكرنا سلفاً أن اتفاقات الكونسورتيوم بين أعضائه لا تؤدي إلى تكوين شخصية

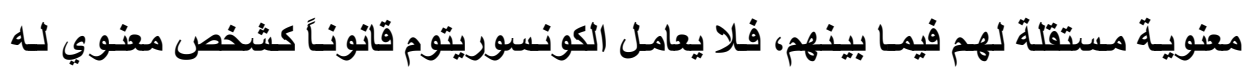

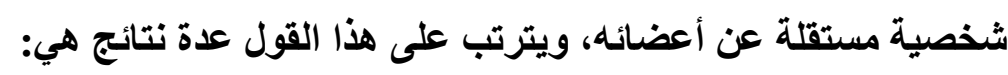
أولاً: لا يوجد رأسمال مشترك للكونسورتيوم:

إن عدم تمتع الكونسورتيوم بالثخصية المعنوية المستقلة يؤدي إلى أنه لا يتمتع

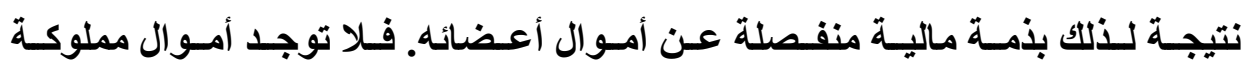

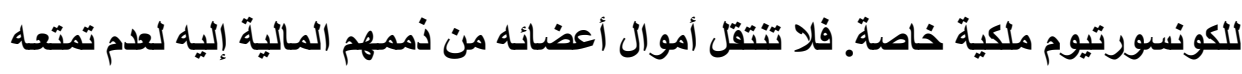
بذمة مالية مستقلة. ويترتب على ذلك أن أي حساب مصرفي يتم فتحسه باسم أعضاء

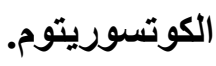

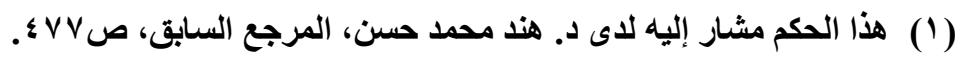

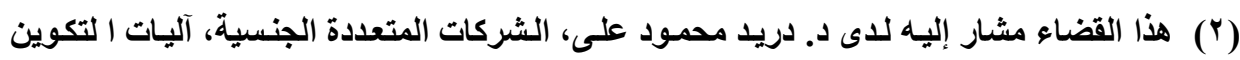

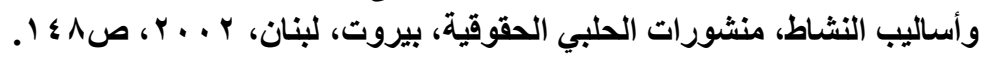


فـلا يقدام أعضاء الكونسورتيوم حصصاً عنــ تكوينه، و إنمـا يكون لكل عضو رأسماله الخاص به يتم تخصيصه لتنفيذ الجزء الخاص المسند إليه من الأعمال. وهذا القول مؤداه أنتـا في حالـة الكونسورتيوم لا نكون أمسام إلا الذمم الماليـة

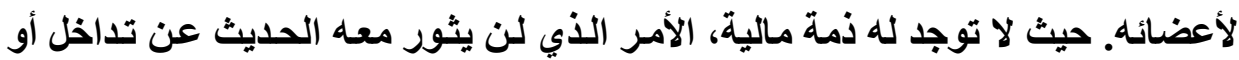

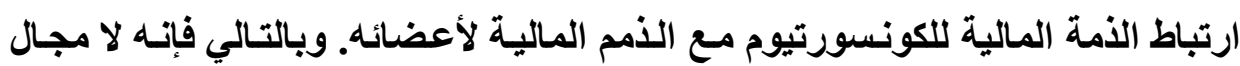
أصلاً للحديث عن مسئولية هؤلاء الأعضاء من أعمال وديون الكونسورتيوم. إلا أن طبيعـة تنفيـذ المـشروع قــ تقتضـي وجـود بعض النفقـات المشتركة مـن أعضاء الكونسورتيوم. وتللك النفقات تقسم بينهم حسب مساهمة كل عضو في الأعمـال، ويتحمل كل عضو دفع نصيبه في تلك النفقات دون أن تداخل الأمم المالية للأعضاء في في الأبمات هذا الخصوص. ثانياً: الارتباط بين الأمم المالية لأعضاء الكونسورتيوم: يحدد اتفاق الكونسورتيوم الذي يبرم بين أعضائه حقوقهم والتزامـاتهم وأحكام

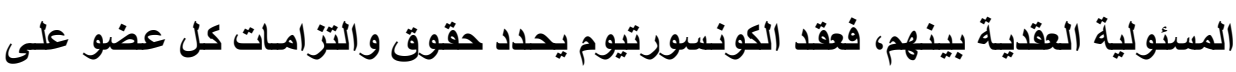
حدة تجاه رب العمل. فلا يكتسب أي منهم حقاً مقرراً لغيره من الأعضاء ولا يتحمل عنـه

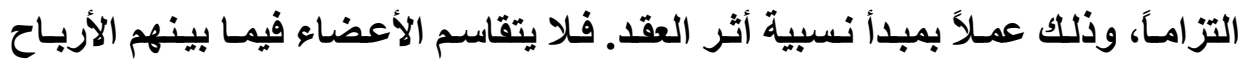
والخسائر الناتجة عن الأعمال. فكل عضو يحصل وحده على الربح الذي يتحقق من تنفيذ العمل المنوط به، كما أنه يتحمل وحده الخسائر التي تنجم عن تنفيذ هذا العمل.

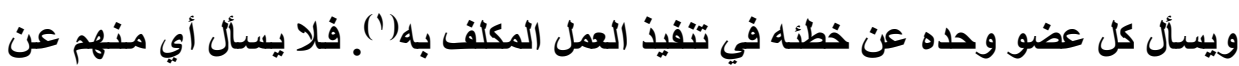
أعمال او أخطاء الآخرين. 
ثالثاً: ارتباط الذمم المالية لأعضاء الكونسورتيوم تجاه رب العمل:

يعتبر التزام أعضاء الكونسورتيوم تجاه رب العمل التزامـاً تجارياً باعتبار أنهم

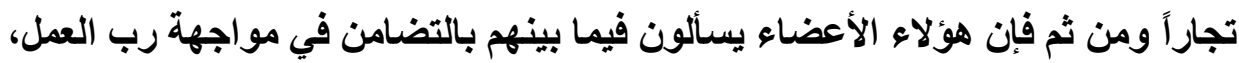

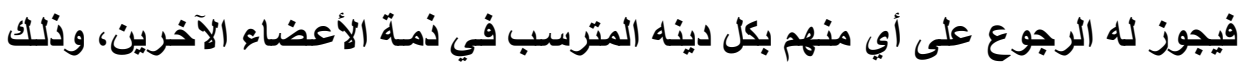

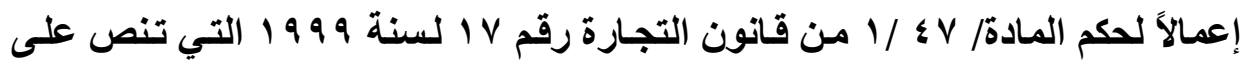

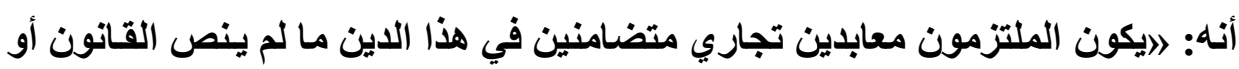
الاتفاق على غير ذلك.... أنهان. وعلى ذلكت فبإذا أراد أعضاء الكونسورتيوم التخلص من هذا التضامن فيجب النص في العقد المبرم بينهم وبين رب العمل على عدم التضامن بينهم تجاهه. ويترتب على المسئولية التضامنية لأعضاء الكونسورتيوم تجاه رب العمل، تداخل وارتباط ذمهم المالية مع الأمة المالية لهذا الأخير.

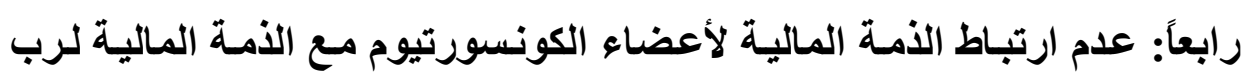

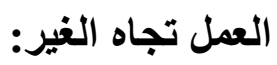

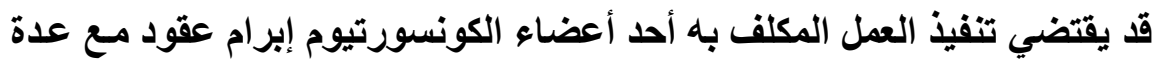

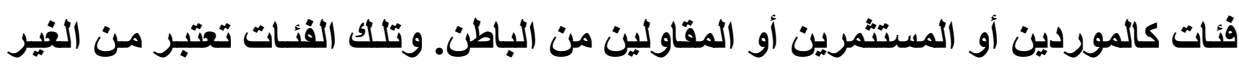

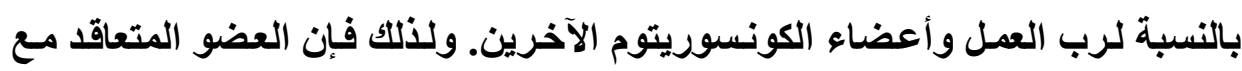

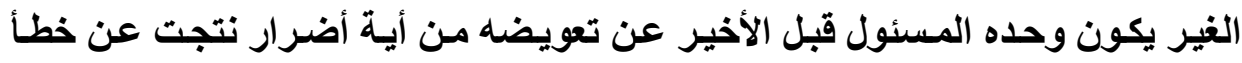

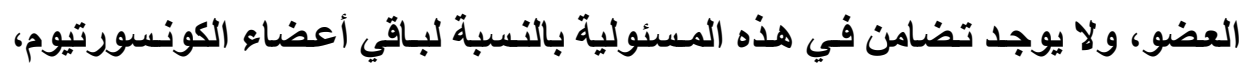

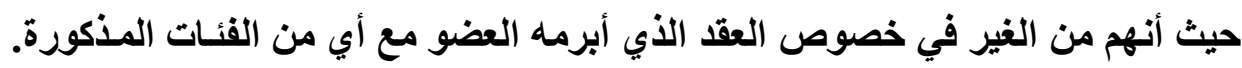

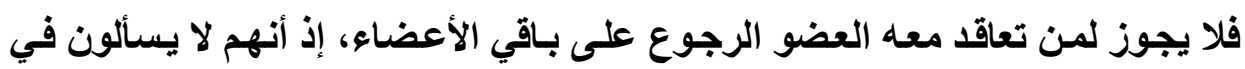
مواجهة هذا المتعاقد لا مسئولية تضامنية ولا غير تضامنية. 
ومن نتائج غياب المسئولية التضامنية لباقي أعضاء الكونسورتيوم وعدم وجود ارتباط بين ذمههم المالية والذمة المالية للعضو الذي تعاقد مع الغير، أنه عند التقاضسي تكون الخصومة القضائية أو التحكيمية بين الغير والعضو الذي تعاقد معده، ولا يجوز اختصام باقي أعضاء الكونسورتيوم في هذه الخصومة'('). 


\section{الفصل الثالث}

\section{الاستقلال بين العلاقات الناشئة عن العمليات الصـرفية}

نظم المشرع المصري، ولأول مرة، العمليات المصرفية حيث أفرد لها قانون

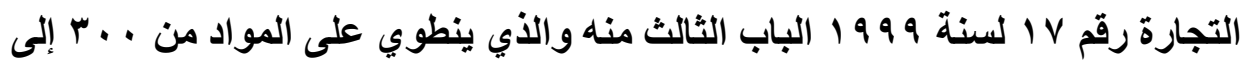

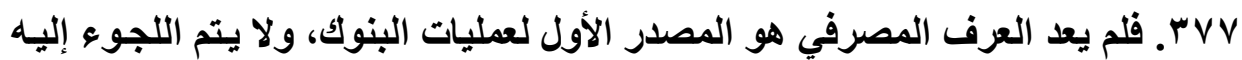

وتطبيقه إلا إذا أحال عليه قانون التجارة المذكور (').

كما أن المشرع في القانون المذكور قد أحال، ولأول مرة أيضاً، على القواعد

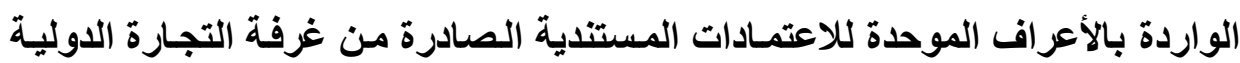

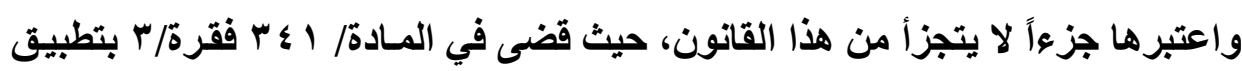

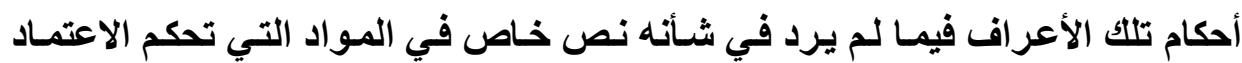

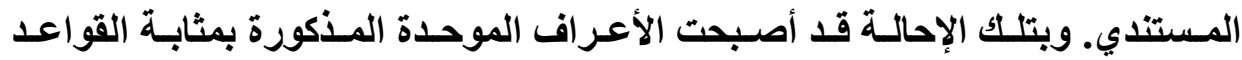

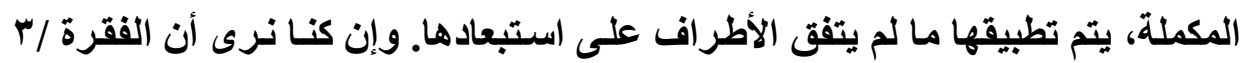

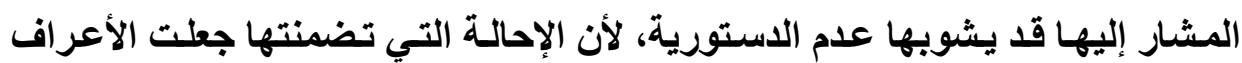

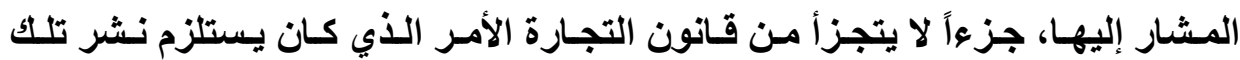

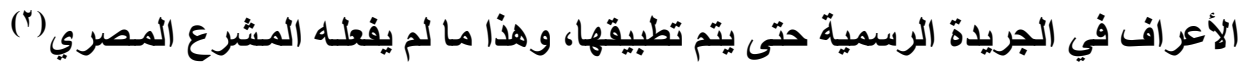

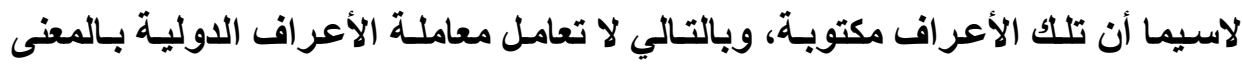

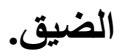

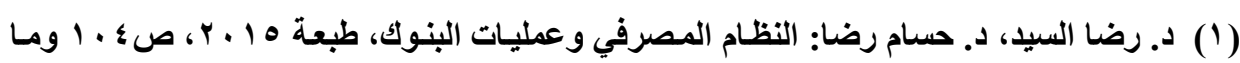
بعدها، دار النهضة العربية.

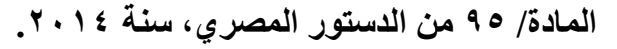


وعمليات البنوك عديدة، ولكن مـا يهنــا منهـا في مجـال هذه الاراسـة العمليـات

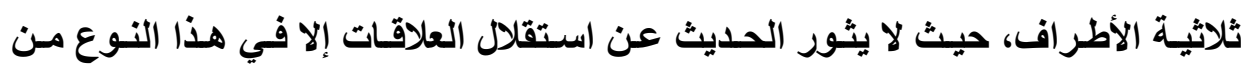

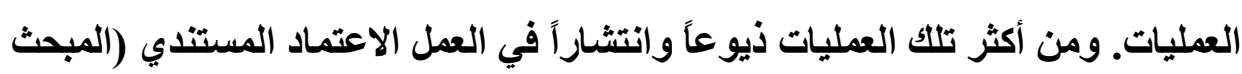
الأول) وخطاب الضمان (المبحث الثاني).

وقبل الاسترسال في الحديث عن العلاقات التي تنشأ عن هـاتين العمليتين ومدى استقلالها عن بعضها، وأثر هذا الاستقلال على التزامات أطرافها، هنـاك ملاحظة يتعين

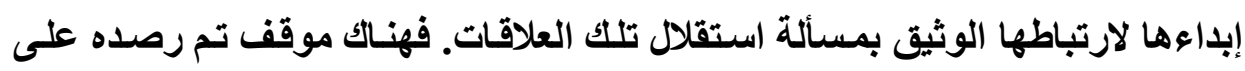

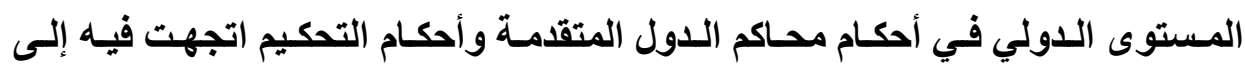

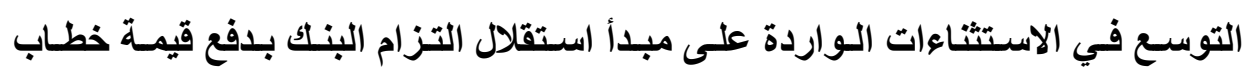
الضمان عن علاقة الأسسا، والتضييق من تلك الاستثناءات عندما يتعلق الأمر بـالتزام البنك بدفع قيمة الاعتماد المستتدي. فاستقلال التزام البنك بالدفع يعتبر ضمانة مقررة

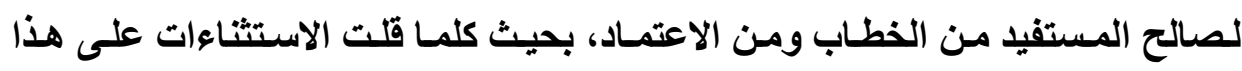
الاستقلال كان ذلك في مصلحة العميل الآمر وضــــــ مصلحة المستفيد، إذ أن الاستثناء يؤدي إلى زوال الاستقلال ومن ثم الربط بين علاقة الأساس والتزام البنك بالدفع، فيحق دالقي

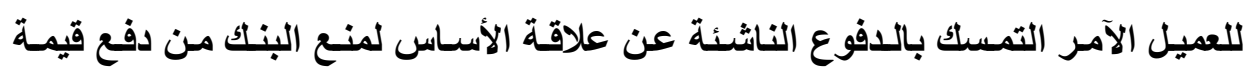
الاعتماد المستتدي وخطاب الضمان. وحيث أنـه في الغالب الأعم يكون العميل الآمـر بخطاب الضمان من رعايا دول العالم المتقلم فإن كثرة الاستثناءات على مبدأ الاستقلال

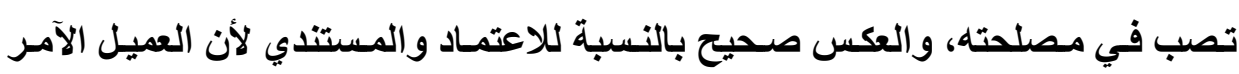

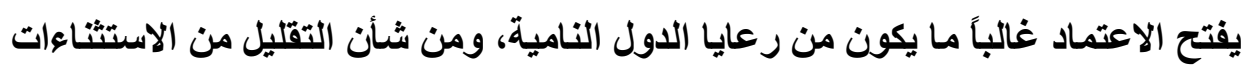
على مبدأ الاستقلال الإضرار به لصالح المستفيد الذي ينتمـي غالبـاً لرعايـة دول العـالم 


\section{المبحث الأول \\ العلاقات الناشئة عن الاعتماد المستندي \\ وهدى استقللاها}

أطراف الاعتمـاد المستتدي، من حيث الأصل، ثلاثة، وأحيانـاً قد يكونوا أربعة. و هذا التعدد في أطراف الاعتماد يؤدي بطبيعة الحسال إلى تعدد العلاقات الناشئة عنده

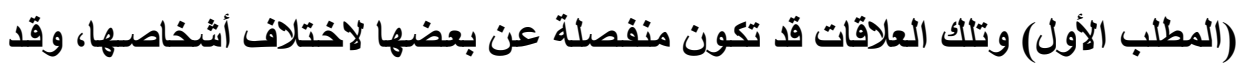
تكون مرتبطة بيضعها لوجود أحد الأثخاص كقاسم مشترك بينها. فما مدى استقالدال تلك العلاقات في ضوء هذا الانفصال والارتباط؟ (المطلب الثاني). المطاب الأول

\section{علاقات الاعتهماد المستندي}

أطراف الاعتمـاد المستندي، بحسب الأصل، هم: العميل الآمر بفتح الاعتمـاد،

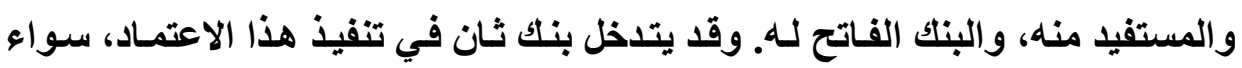

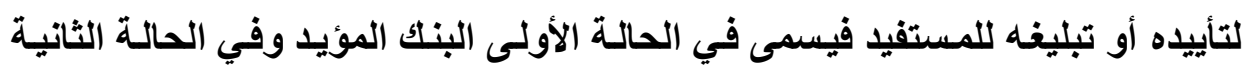

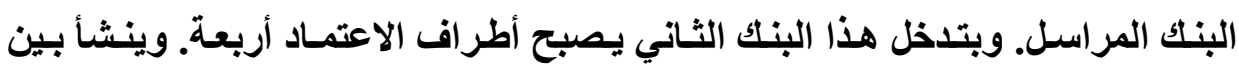
هؤلاء الأطراف عدة علاقات تتمثل في: العلاقة بين العميل الآمر والمستفيد (الفرع

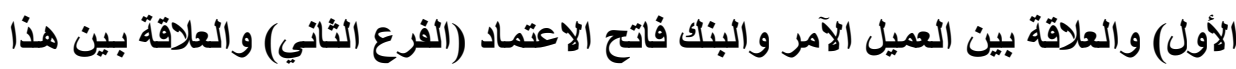

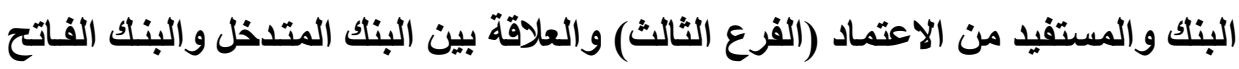

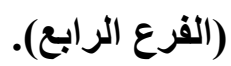




\section{الفرع الأول}

\section{علاقة العميل الآهر (المورد)}

\section{بالمستفيد (المستورد)}

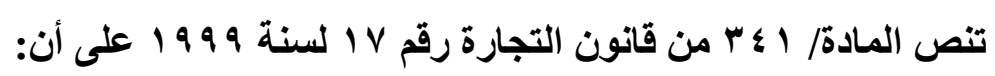

الاعتماد المستندي عقد يتعهد البنك بمقتضاه بفتح اعتمـاد بنـاء على طلب أحد

عملائه (يسمى الآمر) لصالح شخص آخر (يسمى المستفيل) بضمان مستندات تمثل

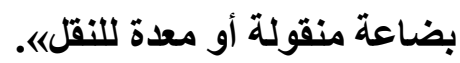

فمن مفترضات وجود الاعتماد المستندي، وفقاً لهذا النص، أن يكون هناك ابتداء عقد توريد بضائع يتم إبرامـه بين المورد والمستورد، يتفقان في أحد بنوده على أن يدفع ثمن البضاعة عن طريق اعتماد مستندي يفتحه المستورد لاى أحد البنوك لصالح

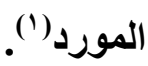

فهناك علاقة سابقة على فتح الاعتماد تسمى 》علاقة الأساس《 يحكمها عقد بين

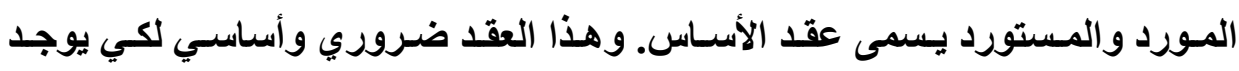
الاعتماد المستتدي، فبدونه لا ينشأ هذا الاعتماد. فيجب أن يكون هذا العقد قائمساً وقت

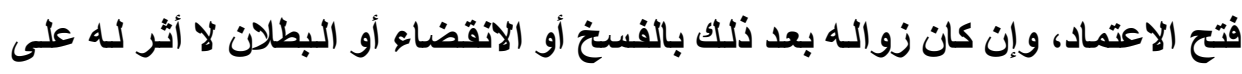
وجود الاعتماد، طالما أن هذا العقد كان قائماً وقت فتح الاعتمـاد. وهذا أمر طبيعي لأن الأن منح الاعتماد يتم تنفيذاً لأحد بنود هذا لاعندا لعقد.

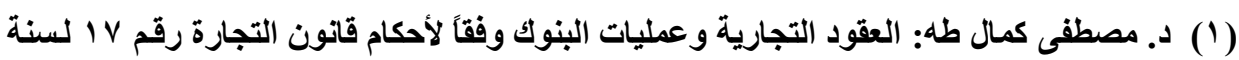

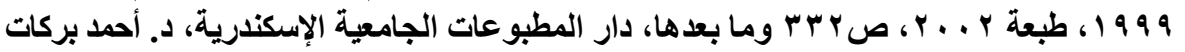

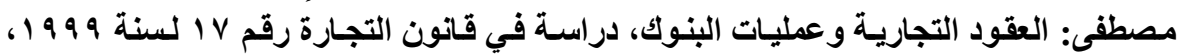

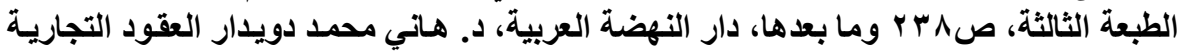

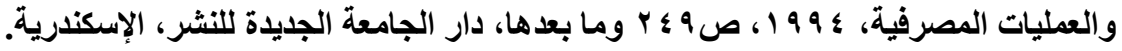


ويرتب هذا العقد مجموعة من الالتزامات على عاتق كل من المورد والمستورد

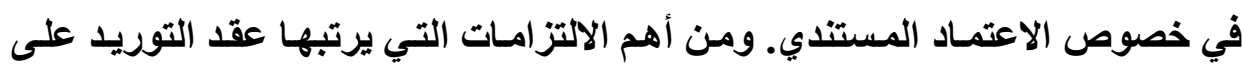

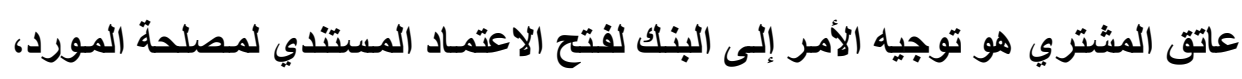

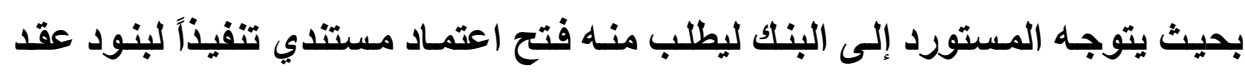

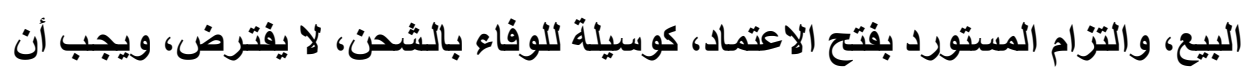
ينص عليه صراحة في العقد حيث أنه يعتبر عنصراً جوهرياً فيه ('). ويتم فتح الاعتماد في التاريخ المتفق عليه بين الطرفين،البائع والمشتري. أما إذا لم يتفق على هذا التاريخ، فإنه يجب أن يكون الاعتماد تحت تصرف البائع المستفيد قبل

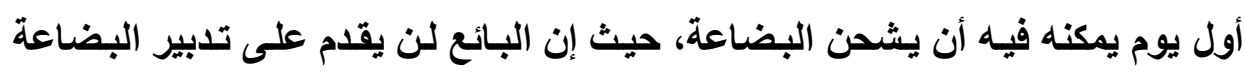

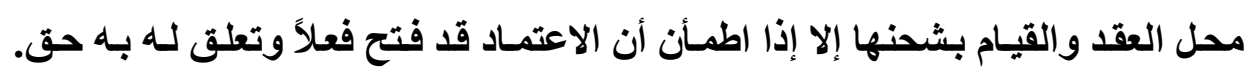
وتجدر الإثـارة إلى أن هذه رخصة مقررة لمصلحة البائع ولـه التـــازل عنها بتدبير البضاعة وشحنها بالفعل قبل أن يدبر المشتري الاعتماد المستندي. ويظل هذا الاعتماد صالحاً لحين انتهاء المدة المتفق عليها بين البائع والمشتري، وفي حالة عدم الاتفاق على هذه المدة، فإن الاعتمـاد يجب أن يظل سـارياً طوال المدة

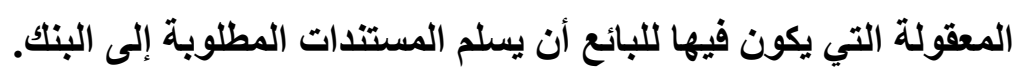
ويلتزم المشتري بتدبيز الاعتمـاد بذات العملـة المتفق عليها، وفي حالـة عدم

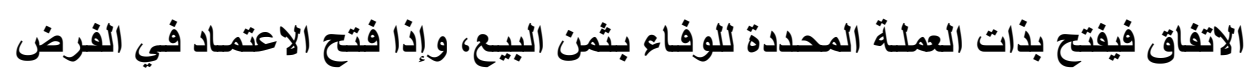

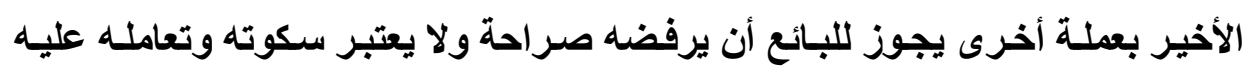

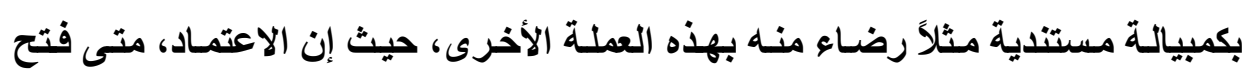
وقبله البائع فكأنه استوفى الثمن وبشكل نهائي.

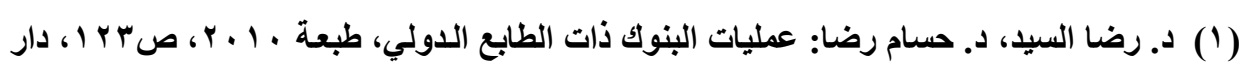
النهضة العربية. 
أمسا عن تحديد البنك الذي يقوم بفتح الاعتماد فيتفق عليه بين البائع والمشتري،

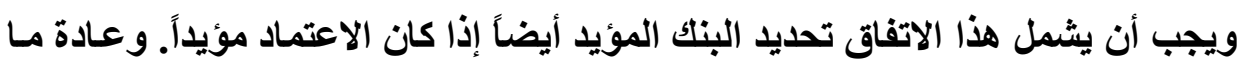
يوجد البنك المؤيد في بلد البائع لسهولة التقدم إليسه بالمستتدات المطلوبـة، واستيفاء قيمة الاعتماد. وفي حالة عدم تحديد البنك في اتفاق البائع والمثتري، يحق لهذا الأخير

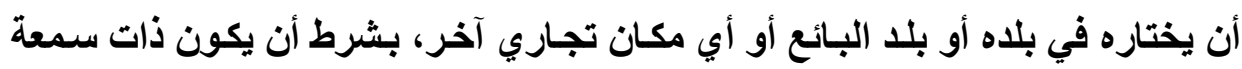
طيبة.

وهكذا، فـإن التزام البـائع بتــبير البضاعة محل البيـع وشـــهـا يقابلـه التزام

المشتري بتدبير الاعتمـاد، بحيث يستطيع البائع - طبقاً للقواعد العامـة في القانون المدني - أن يتمسك بعدم تتفيذ التزامه إذا لم يقم المشتري بفتح الاعتماد فعلاً. ونظراً للاتفـاق في عقد الأسـاس على أن ثــن البضـاعة سـيدفعه البنـك فـاتح

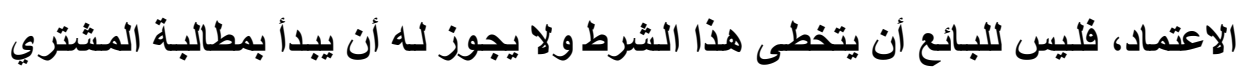
مباشرة طالما أن المدة المقررة في الاعتماد لا تزال مفتوحة أمامه. ولكي يستطيع البائع

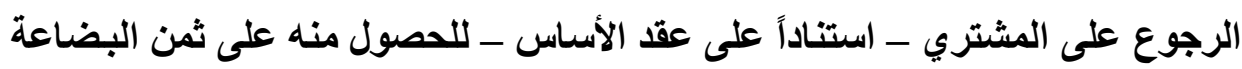
عليها أن يثبت أنـه طالب البنـك بقيمـة الاعتمـاد ولكن دون جدوى. ويكفي هنـا أن تتم المطالبة في أي شكل ولا يشترط أن تكون قضائية.

ولكن قد تنقضي المدة المحددة للاعتماد المستندي دون أن يقدم البائع (المستفيا) المستندات المطلوبة إلى البنك، فيكون له أن يرجع مباشرة إلى المشتري بـالثمن نظراً

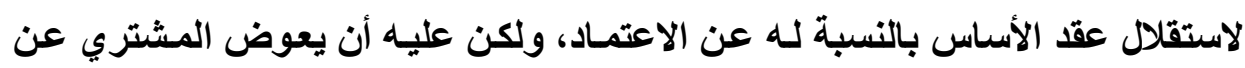
مصاريف فتح الاعتماد. وتجدر الإثـارة إلى أن مسميات طرفي علاقة الأسـاس تتفير بعد فتح الاعتمـاد. فيصبح المستورد عميلاً آمراً، ويضحي المورد مستفيداً. إلا أن تغيير المسمى لا يعني نشوء علاقة جديدة بين العميل الآمر والمستفيد، حيث تظل العلاقة بينهما علاقة واحدة، 
وهي عقد الأسـاس فيجب النظر إلى هذه المسميات الجديدة مـن منظور البنـك فـاتح الاعتماد، حيث أن مسمي العميل الآمر يعني أنه يوجه أمره إلى هذا البنتك ليفتح اعتمـاد

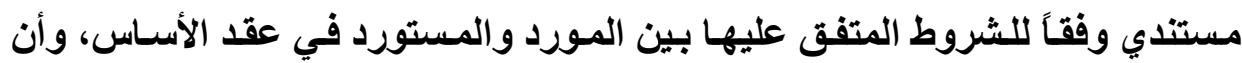
مسمى المستفيا يعني أن البنك يفتح الاعتماد لمصلحته.

فالالتزامات التي تقع على عاتق الطرفين والحقوق التي يتمتعان بها، حتى بعد

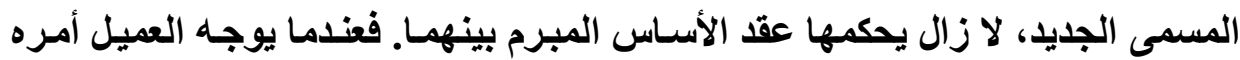

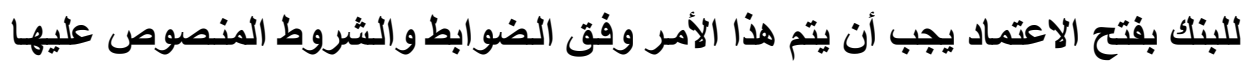
في بند فتح الاعتمـاد الوارد في عقد الأسـاس، من حيث نـوع الاعتمــاد وتـاريخ بدايته

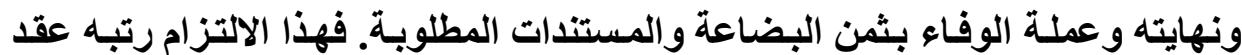
الأساس على عاتق المستورد الذي أصبح عميلاً آمراً بعد فتح الاعتمـاد، ويظل خاضعاً لهذا العقد. فقتح الاعتماد ليس تجديداً للالتزام الوارد في عقد الأسـاس ('). وكذلك الأمـر بالنسبة للمستفيد فإن حقوقه والتزاماته تظل خاضعة لعقد الأساس. وعلى ذلك فإنه لا يوجد بين المورد (المستفيد) والمستورد (العميل الآمر) سوى علاقة واحدة هي علاقة الأسـاس ومن ثم فلن يثور الحديث من استقلال العلاقة بين العميل الآمر والمستقيد والعلاقة بين المورد والمستورد لأنهما علاقة واحدة.

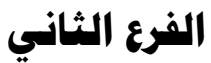

\section{علاقة البنـك الفاتح بالمستورد (العـميل الآهمر)}

يحكم هذه العلاقة عقد الاعتمــاد المستتدي. فمتى أبرم عقد البيع، وتعهد فيـه المشتري بفتح اعتماد مستتدي للوفـاء بثمن البضاعة، فإنـه يتوجه إلى مصرفه طالبـاً 
فتح اعتماد لصالح البائع، وذلك بملع بيانات طلب فتح الاعتماد وهو نموذج يعده البنك مقدماً لهذا الغرض، ويعتبر طلب فتح الاعتمـاد إيجابـاً من قبل المشتري متى صـادفه قبول من البنك ينعقد بين البنك والمشتري عقد الاعتماد المستندي.

ويرتب هذا العقد مجموعة من الالتزامـات على عـاتق المشتري (الآمر). فيجب

عليه الإبقاء على التعليمات التي أصدرها البنك في طلب فتح الاعتماد حتى لا يضر بهذان الأخير الأي أبلغ تلك التعليمات بمقتضى خطاب الاعتماد إلى المستفيد والتزم بتنفيذها.

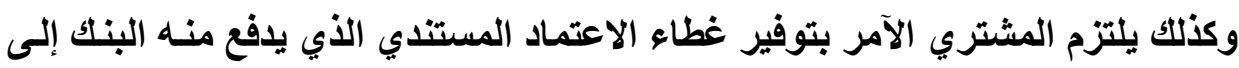
المستفيد، وفي حالة عدم توفير هذا الغطاء يلتزم المشتري (الآمر) بتعويض البنك عن قيمة ما دفعه. وفضلاً عن ذلك، فإن المشتري يلتزم بدفع العمولة المتفق عليها، والتي تتناسب قيمتها تناسباً عكسياً مع قيمة غطاء الاعتمـاد. وقد يتفق المشتري مـع البنتك على تحصيل هذه العمولة من المستقيد، وينص على ذلك في خطاب الاعتماد، بشرط أن يقبلها المستفيد وإلا رجع بها البنك على الآمر (1). وبعد أن يدفع البنك قيمة المستتدات التي تأكد من سلامتها ومطابقتها لشروط فتح الاعتماد، فإنه يخطر المشتري الآمر بوجود المستثدات تحت يده وأنها تحت تصرفه

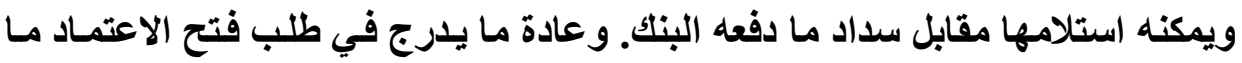
يلزم المشتري بتسلم المستندات، حيث ينص في هذا الطلب على تلك العبارة: ارنتعهد بسحب المستتدات التي ترد إليكم في بحر أسبوع من تـاريخ أخطارنـا بوصولها بخطاب

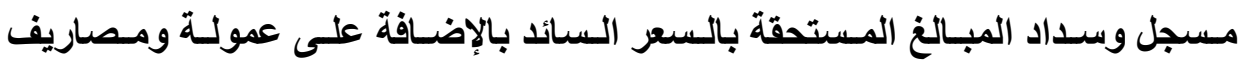
مراسليكمب، ويترتب على أعذار البنك للمشتري الآمر بتلقي المستتات، نقل تبعة هلاك بلك 
البضاعة وتلفها على عاتقه، وتحمله كافة الرسوم الجمركية المستحقة عن التأخير في سحبها.

هذا، وتقضي المـادة/ • ه ب من قانون التجـارة. في هذا الخصوص، بأنـه إذا لم يدفع الآمر إلى البنك قيمة المستتدات المطابقة لشروط فتح الاعتمـاد خلال ستة أشـهر

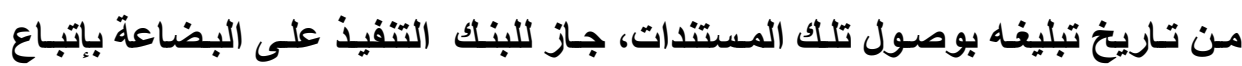

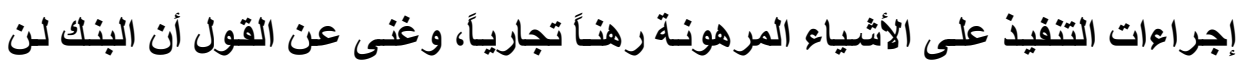
يسنطيع مباشرة تلك الإجراءات إلا إذا كان حائزاً للمستندات التي تمثل البضاعة البهاء المراد

التنفيذ عليها (1)

ولكـن يحـق للآمـر، قبـل تـسلم المستثندات، أن يفحصها ليتأكسـ مسن سـلامتها

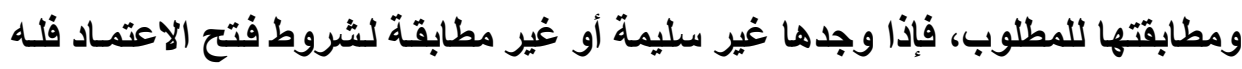

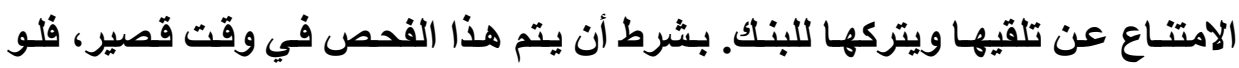
تراخي المستفيد في ذلك أو قبل المستندات فلا يستطيع أن يتركها للبنك ويترتب على الترك مجموعة من النتائج هي: ـ أن تبعه هـلاك البضاعة أو تلفها تظل على عـاتق البنك ولا تنتقل إلى المشتري الآمر، وذلك لأن نقل عبء تلك التبعة إلى المشتري مرهون بتلقيه للمستتدات. ـ أن البنك يظل حائزاً للمستتدات، وبالتالي حائزاً للبضاعة التي تمثلها. ويكون لـه تسلم البضاعة وبيعها لحسابه ليقتضي من قيمتها قيمة ما دفعه للمستفيد، ويكون له أيضاً أن برد المستندات إلى المستفيد ويطالبه برد ما قبضه إذا كان الدفع قد تم تحت تحفظ أو قدم المستفيا مقابل ذلك ضماناً مـا. إلا أن هذه المستتدات غالباً مـا تصدر لأمر أو إذن المشتري الآمر، وبالتـالي يجب الحصول على تظهيره على 
المستندات للبنك حتى يـمكن من التصرف في البضاعة. ولكن موافقة المشتري على هذا التظهير قد لا تكون بالأمر السهل نظراً لما يرتبه هذا التظهير من نتائج

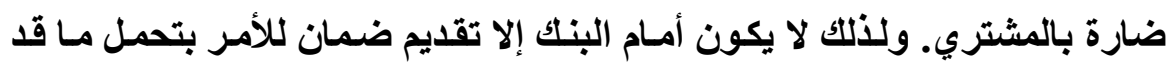
يتعرض له من مضار مقابل قيامه بتظهير المستثدات له.

أما الالتزامات التي تقع على عاتق البنك في مواجهة العميل الآمر، فتتمثل أساسـاً

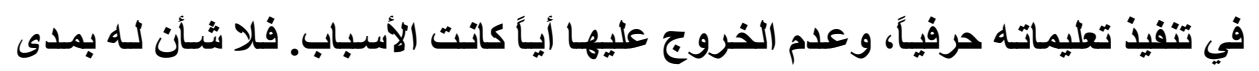
مطابقة تلك التعليمات لمضمون عقد البيع الذي فتح الاعتمـاد بمناسبته إذا وصل هذاب المضمون إلى علم البنك.

والأصل أن تعليمات الآمر تكون كاملة وواضحة وخالية من التفصيلات المبالغ

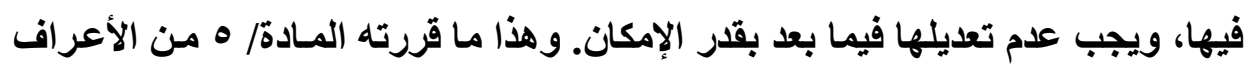

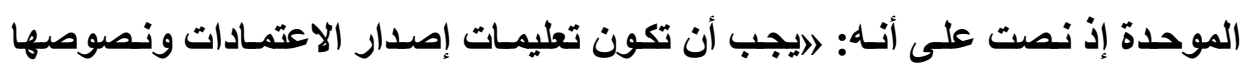
وطلب تعديلها ونصوص التعديل كاملة ومحددة. وبهدف الوقاية من سوء الفهم وحدوث

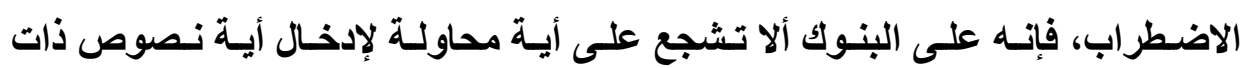
تفصيلات مبالغ فيها في الاعتماد أو في أي تعديل لا حق لهاهـ. أمسا إذا كانت تعليمـات الآمـر للبنك ناقصة أو بها أخطاء بحيث لا يمكن تنفيذها بحالتها، فعلى البنك أن يطلب من عميله تكملتها أو تصحيحها، ولا يتحرك البنك قبل ذلك تجاه المستقيد وإلا كان مسئولاً عن تصرفه. وتنص المـادة/ء أ من الأعراف الموحدة

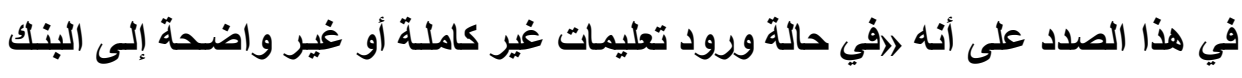

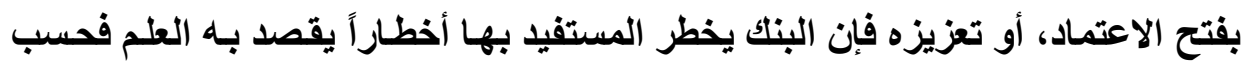
دون مسئولية على البنك. ولا يفتح البنك الاعتماد أو يعزه أو يخطر بـه أخطاراً نهائياً

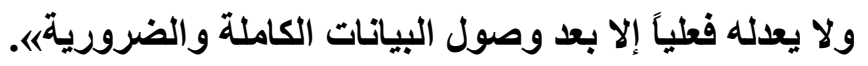


وعلى البنك أيضاً أن يفتح الاعتماد لصالح المستفيد الأي حدده الآمر في طلبه،

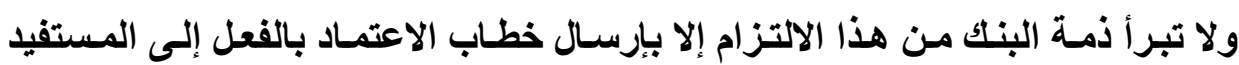

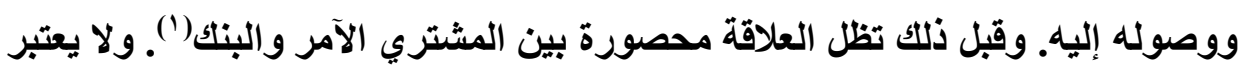
المشتري قد أوفى بالتزامه الوارد في عقد البيع تجـاه المستفيل إلا بقيـام البنك بارسـال

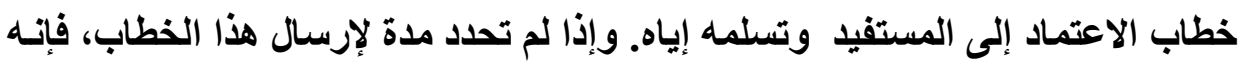

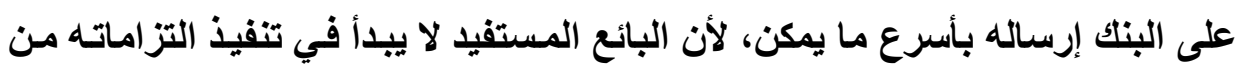
حيث تدبير البضاعة إلا بعد إخطاره بفتح الاعتماد. وتضيف ذات الفقرة أن هذا الالتزام

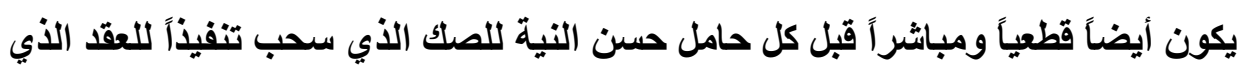
فتح الاعتماد بسبيه. والفرض الأي يعالجهه هذا الحكم هو حالـة الوفـاء بقيمـة الاعتمـاد

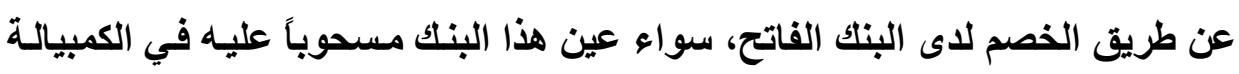

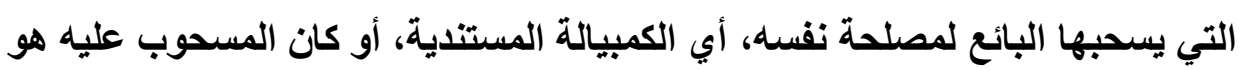
المشتري أو أي شخص آخر في كمبيالة أو سند إذنسي سحبها المشتري لصالح نفسه.

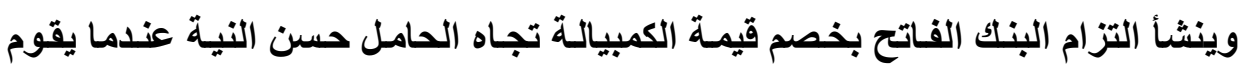
المستفيد من الكمبيالة المستندية بتظهيرهـا أو تظهير الكمبيالة العادية أو السند لأمر

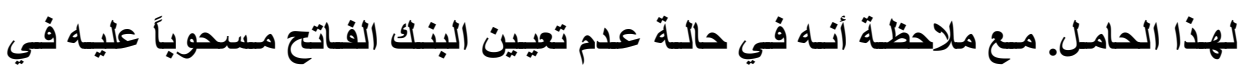
الكمبيالة محل الخصم، فإنه لا يستطيع، بعد خصمها، الرجوع بقيمتها على المظهرين

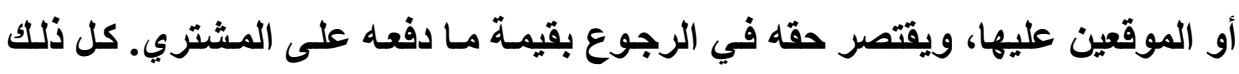
بطبيعة الحال يقتضي النص صراحة في عقد فتح الاعتماد على التزام البنك بالخصم. والأصل أن المستفيد لا يحصل على قيمة الاعتماد إلا إذا قدم المستتدات المطلوبـة

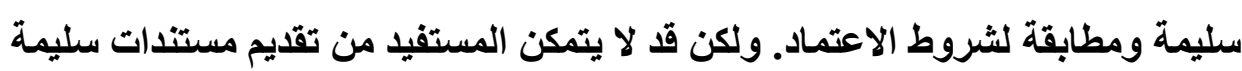


أو مطابقة تماماً، ويؤكد للبنـك أن المخالفـات الواردة بالمستتـات طفيفـة ولن يعترض

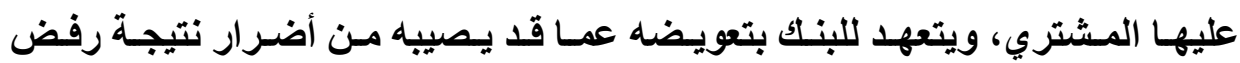
المشتري للمستتدات، ولضمان هذا التعهد يقدم المستفيد كفالة مصرفية من بنك آخر.

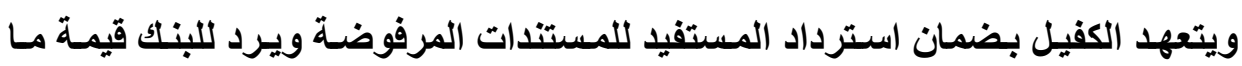

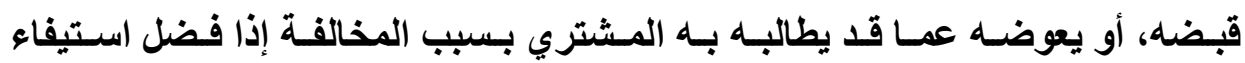

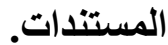

وقيـام البنـك في الفـرض السـابق بـدفع قيمـة الاعتمــاد يكون بمثابـة التسوية

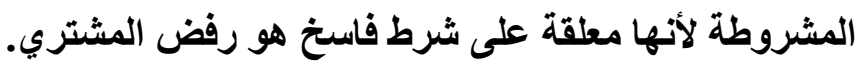

\section{الفرع الثالث}

\section{علاقة البنـاك الفاتح بالمورد (المستفيد)}

يحكم العلاقة بين البنك فـاتح الاعتمـاد والمستفيد منـه خطـاب فتح الاعتمـاد الذي

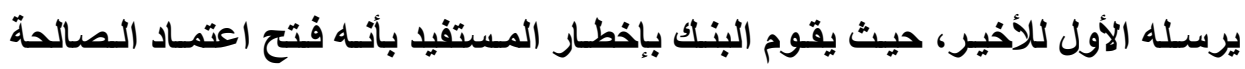
بشروط معينة، ويتعهد له بموجب هذا الخطاب أن يدفع له قيمة الاعتماد بمجرد أن يقدم له مستندات معينة في خلال مدة محددة. ولخطاب فتح الاعتماد letter de credit أهمية كبيرة لأنه يحدد مضمون التزام البنك وحقوق المستفيد. وهذا الخطاب إسمي يصدر باسم المستقيل ومن ثم فلا يكون قابلاً للتداول بالطرق التجارية. وإن إصدار الخطاب المذكور من جانب البنك وإرسـاله للمستفيل منـه يلزم البنـك منذ لحظة وصوله للأخير دون انتظار قبوله، حيث لا يضيف قبول المستفيل للخطاب

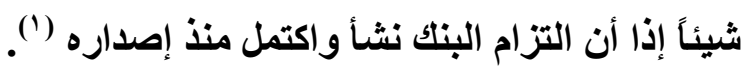

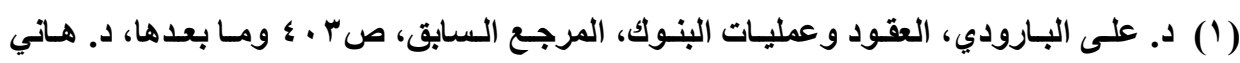

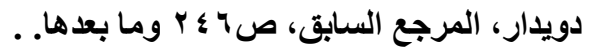

VO. 
ولكن إذا وجد المستفيد أن شروط الاعتماد المنصوص عليها في الخطاب مخالفة لما اتفق عليه مع المستورد جاز لله رفض الاعتماد استناداً إلى عقد الأساس. ولا يكون من حق المورد مناقشة البنتك في ذلك وإنمـا يرجع إلى المستورد وحده بطلب تعديل شروط الخطاب طبقاً للمتفق عليه بينهما في عقد الأساس. ومصدر حق المستفيد في مواجهة البنك يتمثل في الإرادة المنفردة لهذا الأخير.

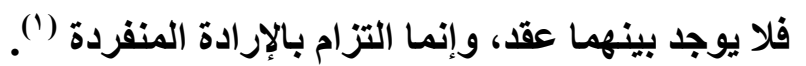

\section{الفرع الرابع}

\section{علاقة البنك الفاتج بالبنك الإتدخل}

قد يقوم البنـك فـاتح الاعتمـاد بإخطسار المستفيد رأسـاً بفتح الاعتمـاد، وقـد يتم الإخطار عن طريث بنك وسيط في بلد المستفيد، وهذا هو الوضع الغالب لمـا ينطوي عليه من مزايا للمستفيد. والبنك الوسيط قد يكون مؤيداً للاعتماد أو مجرد مبلفاً له. وقد أشدارت إلى هذا التقسيم المادة/ ؟ ؟ ب من قانون التجارة التي تنص على أنه: 》ا - يجوز تأييد الاعتمـاد المستندي البـات من بنتك آخر يلتزم بـدوره بصورة قطعية

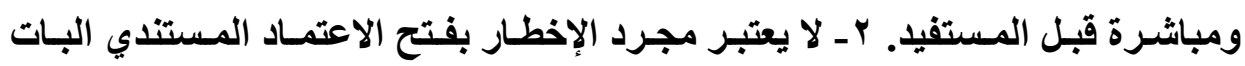
المرسل إلى المستفيد عن طريق بنك آخر تأييداً من هذا البنك للاعتمادها.

وقد ورد هذا التقسيم أيضاً في المـادتين/ ^ و • ا من الأعراف الموحدة، حيث

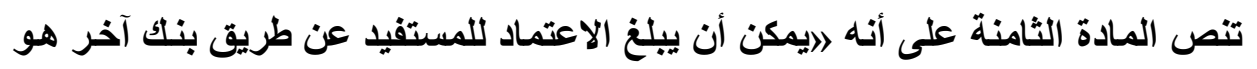
البنك المراسل أو مُبلغ الاعتماد، دون أن يلتزم الأخير بمقتضاه، ولكن هذا البنك يلتزم

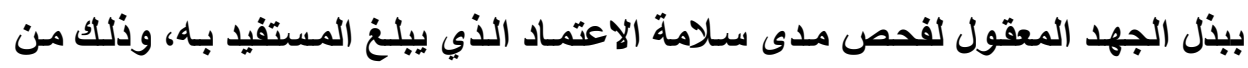

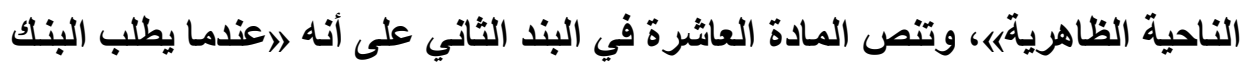


فـاتح الاعتمـاد أو يفوض بنكـاً آخر لتعزيز هذا الاعتمـاد، ويضيف تعزيزه، فِان هذا التعزيز يعتبر التزاماً قاطعاً في ذمة هذا البنك (البنك المعزز)، بالإضافة إلى التزام البنك

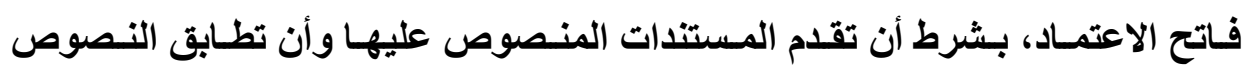

$$
\text { والثروط الواردة في الاعتماد....٪. }
$$

الواضح من هذه النصوص أن البنك المراسل الذي يعينه المستفيد في بلده، يقوم

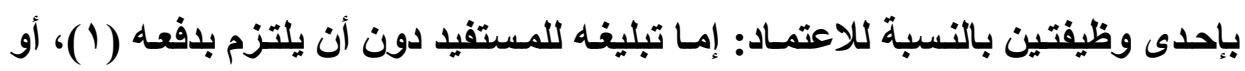
تأييده، أي يلتزم شخصياً بدفع قيمة الاعتماد مثله في ذلك مثل البنك الفاتح تماماً (ץ). ا ـ علاقة البنك الفاتح بالبناك المتلدل المراسل:

قد يستعين البنـك مصدر الاعتمـاد بينـك وسـيط في بلد البـائع المستفيد يكلفهـ

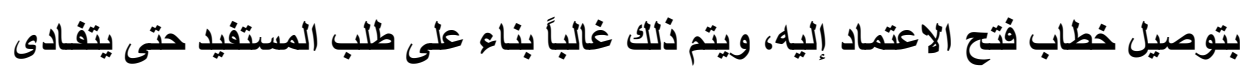

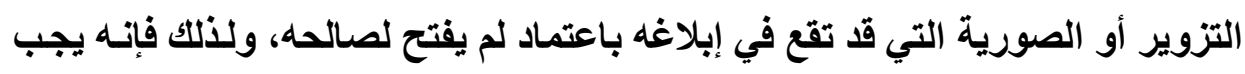
على البنك الوسيط التحقق من الصدق الظاهري للاعتماد المبلغ ('). ويقتصر دور البنتك المراسل في هذا النوع من الاعتمـاد المستندي على مجرد

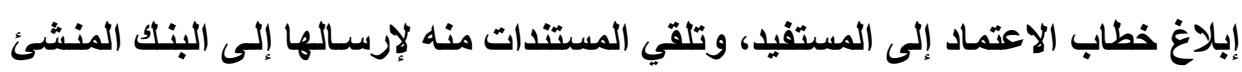
ولا يلتزم البنك المراسل بشيء ما ويكون دوره هو دور الرسول، أي مجرد أداة لتنفيذ

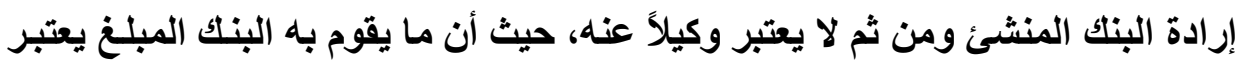

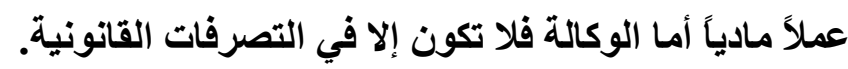

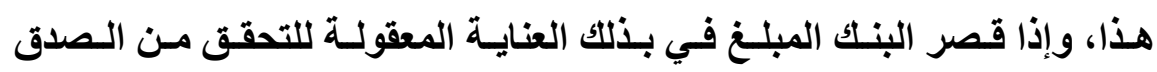
الظاهري للاعتماد الذي يبلغه، كان مسئولًا أمام البائع المستفيد على أسـاس المسئولية 
إلا أن البتك قد يتجاوز دور ساعي البريد فيتعهد بأن يتم تنفيذ الاعتماد لديه وذلك دون تأييد من جانبه. ومسألة كون البنك المراسل مجرد مبلخ للاعتماد أو مكلف في ذات ذات

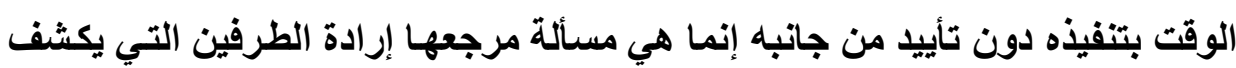

$$
\text { عنها قاضي الموضوع. }
$$

r- علاقة البنك الفاتح بالبنك المتلخل المؤيد:

قد يكون الاعتماد المستتدي مؤيداً ومعززاً، وفي هذا النوع من الاعتماد لا يقتصر

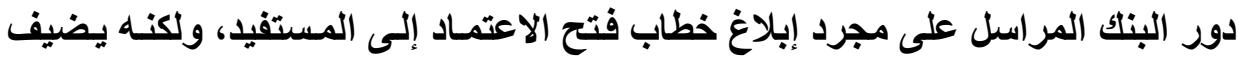
تأييده للاعتماد المستتدي فيلتزم شخصياً بنفس التزام البنك مصدر الاعتمـاد. ويكون

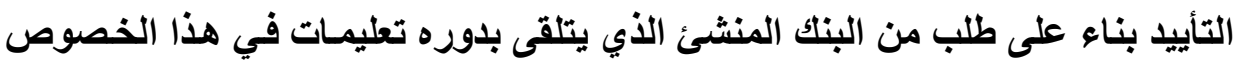

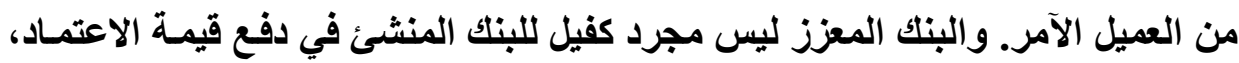

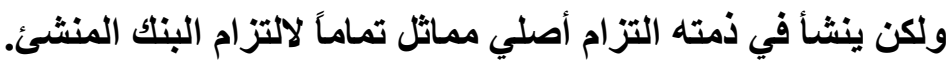
والأصل أن يرد التأييد على الاعتماد المفتوح كما هو، وقد يرد مقيداً بمبلغ أقل منه أو لمدة أقصر، وهنـا تسري تلكل القيود على المستفيد الذي أبلغ بالاعتمساد، لأن العبرة في تحديد التزامات البنك المؤيد هو بالرجوع إلى عبارات خطاب الاعتماد الذي الذي الإني أيده، وذلك بصرف النظر عن خطاب الاعتماد الأصلي. هذا، ويجوز للبنتك المؤيد التمسك بالغش الصادر من المستفيد للامتناع عن دفع

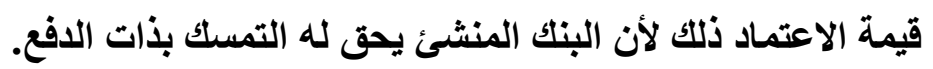
ويحقق الاعتمـاد المؤيد مزايـا عديدة للمستفيد من الاعتمـاد (')، حيث أن التزام

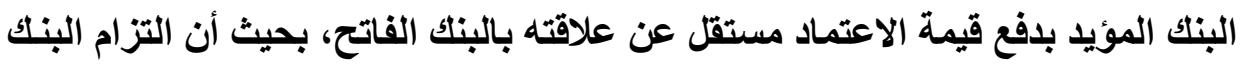

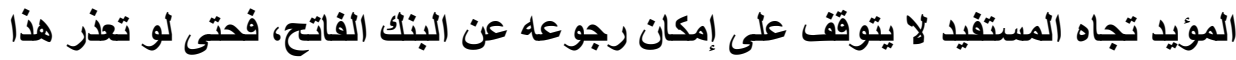


الرجوع، لأسباب اقتصادية أو نقدية أو سياسية، فإن التزام البنك المؤيد تجاه المستفيد يظل قائماً. وهذا الحكم قررته المادة/ ك ؟ ؟ من قانون التجـارة، حيث اعتبرت أن التزام البنك الموئيــ التزامـاً قطعيـاً ومباشراً قبل المستفيد، أي أن التزامسه مضاف إلى التزام البنك المنشئ وليس بديلاً له، فالالتزامان لا يحل أحدهما محل الآخر. ويترتب على ذلك

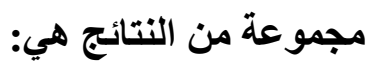

- - أن كلا من البنكين ملتزم بالوفاء بقيمة الاعتماد كاملاً. - لا يجوز لأي من البنكين المطالبة بتقسيم قيمة الاعتماد بينه وبين البنك الآخر. - يرجع البنك المؤيد على البنك المنشئ بقيمية الاعتماد الذي دفعه. - من حق المستفيد مطالبـة أي من البنكين بكل الـين، وإن كـان من الأيسر لـه مطالبة البنك المؤيد لوجوده في بلاه. - الوفاء الحاصل من أي من البنكين يبرئ ذمة البنك الآخر تجاه المستفيد. ولكن يلاحظ أن البنك المنشئ إذا أو في بقيمة الاعتماد فلا يجوز له الرجوع على البنك المؤيد ولكنه يرجع إلى العميل الآمر. وفضلاً عن تلك الميزة، فإن البنك الموئيد عادة مـا يقع في بلد المستفيد، الأمر الذي يمكن المستفيد من سـب كمبيالـة عليـه بقيمسة المستندات، وإذا رفض الوفـاء بقيمتها فإنه يختصمه أمام محاكم بلده، ويكون من السهل تنفيذ الحكم الذي حصل عليه في نفس البلا(') فإصدار تلك الشهادات في ميناء القيام هي الأكثر ذيوعاً وانتشاراً في العمل، حيث تقوم إحدى شركات المعاينة بفحص البضاعة المعدة للنقل، وإذا تأكدت من مطابقتها 
للمواصفات المتفق عليها في عقد الأسـاس تصدر شههادة مطابقة بذلك. وتلكك الشهادة تكون - كما ذكرنا ـ ضمن المستتدات التي يقدمها المورد (المستفيد) إلى البنك الفـاتح. وتلك الشهادة توفر الاطمئنسان للدى المستورد أن البضاعة محل عقد الأسساس مطابقة للمواصفات المتفق عليها في هذا العقد وقت شحنها في مينـاء القيام، فهي تغطي على

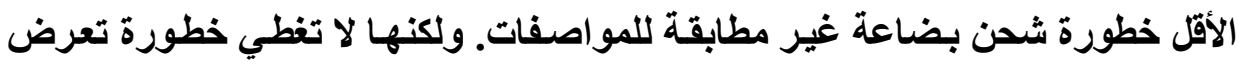
البضاعة للتلف أو الهـلاك أثـاء عمليـة النقل، وإن كانت تلك المخـاطر يمكن تغطيتها بوثيقة التأمين البحري.

وقد يتفق على إصـار شـهادة المطابقة في مينـاء الوصـول. وهذا النـوع مـن

الشهادات غير شـائع في العـل حيث غالبـاً مـا يرفضه المستفيل مـن الاعتمـاد، لأنـه يتناقض مع الهدف من فتح الاعتماد المستندي وفلسفته، حيث يلجأ المورد على الاتفاق على تسوية ثمن البضاعة مع المستورد عن طريق فتح اعتمـاد مستندي لصالحه يتم

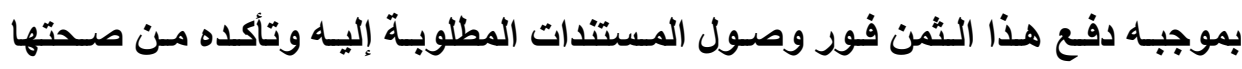
وسلامتها ومطابقتها، فلا ينتظر المورد وصول البضاعة إلى مينـاء الوصول للحصول على ثمنها. فـالمورد يهدف من الاعتمـاد المستتدي إلى سرعة قبض ثمن البضاعة ليحقق بذلك سرعة دوران رأسماله. أما إذا انتظر حتى وصول البضاعة ميناء الوصول لتحرير شهادة مطابقة بها، فلن يتحقق الهدف المنشود من فتح الاعتماد المستثدي.

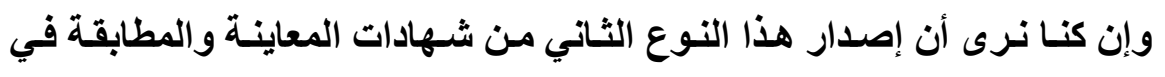
ميناء الوصول هو أكثر السبل حمايـة للمستورد، إذ أنـه في هذه الحالـة يكون مطمئنـاً

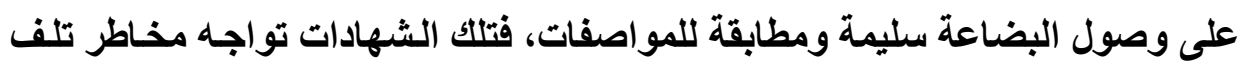
أو هلاك البضاعة أثناء عملية النقل. 
ثانياً: أثر الغش على استقلال التزام البنك بالافع عن عقد الأساس: إن المفهوم التقليدي لمبـأ الاستقلال الكامـل والمطلق لالتزام البنـك بـدفع قيمـة الاعتماد عن عقد الأساس في حاجة إلى إعادة نظر لاسيما أنه يلقي بظلاله السلبية على لإنى

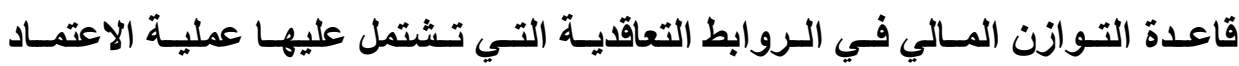
المستتدي، وأصبح كذلك عاجزاً عن مواجهة الممارسات غير المشروعة التي ينتهجها أطراف الاعتماد المستندي، خصوصاً في مجال التجارة الدولية. لذلك فإن الاتجاه الفقهي الحديث، وكذلك بعض أحكام القضاء، قد أقرا ضرورة

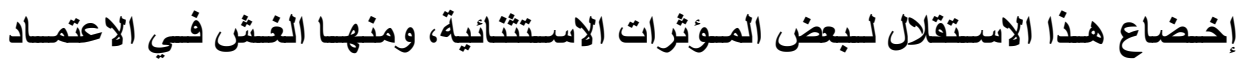
المستندي. فذهبوا إلى أن هذا الغش يعطل مبدأ استقلال التزام البنك بالدفع عن عقد الأساس بحيث يمنع البنك عن الوفاء بقيمة الاعتماد عند ثبوت الغش. ومسألة الغش في الاعتمـاد المستندي معقدة وغير واضحة المعـالم مـن حيث

$$
\text { | ـ تعريف الغش (1) وشروطه وصوره (Y) و وإثباته (Y). }
$$

بدايـة، وقبل الاسترسـال في شـرح أحكـام موضسوع الغش في مجـال الاعتمـاد

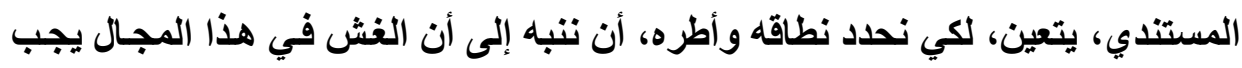
أن يتعلق فقط بالمستندات وليس بالبضاعة، لأن التزام البنك المستقل بالدفع، والذي إني

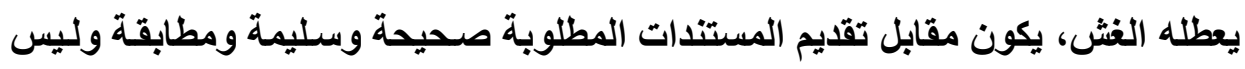
مقابل البضائع. فالبنك لا شأن لله بالبضاعة محل عقد الأساس لأنه لم يكن طرفاً فيه. ولم يرد للفش في الاعتماد المستثدي تعريف لا في الأعراف الدولية الموحدة ولا الاتفاقات الاولية ذات الصلة. 
وقد ورد تعريف للفش والتدليس بصفة عامة في قانون الغش التجاري المصري

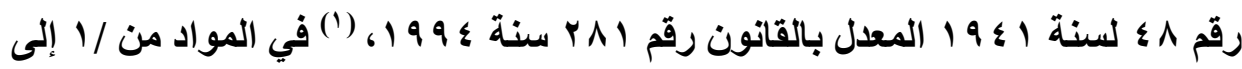
צ منـه. إلا أن هذا التعريف لا يسري ولا يجوز تطبيقه في مجـال الغش في الاعتمـاد المستندي، لأن القانون المذكور عرف الغش من منظور وجود عيوب في البضاعة محل

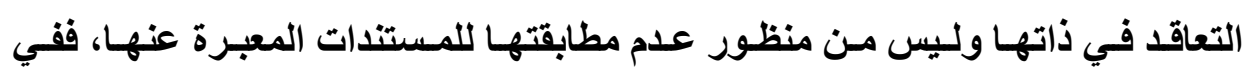

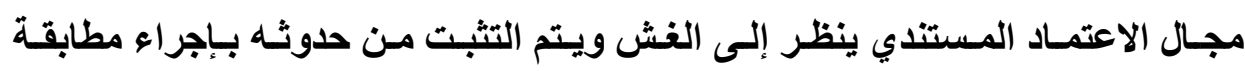
بين المستندات المقدمة إلى البنك الفـاتح من المستفيد والبضاعة محل عقد الأسـاس، فلـو ثبـت أن تلـك المستندات لا تعبر عن البضاعة فنكـون أمسام غش في الاعتمـاد المسنتدي.

وقد ورد للتدليس أيضاً تعريف في القانون المدني المصري حيث تقضي المـادة/ ه r ا منه بأن العقد يكون باطلاً للتدليس إذا كاتت الحيل التي لجأ إليها أحد المتعاقدين،

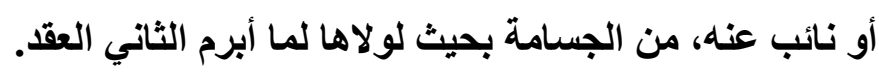
وهذا التعريف أيضاً لا يسري ولا ينطبق على الغش في مجال الاعتماد المستندي،

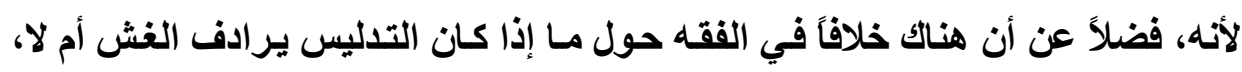
فإن المادة المذكورة من القانون المدني تتحدث عن التدليس كسبب لبطلان العقد وقت إبرامه وليس في مرحلة تنفيذه. أما التمسك بالغش في مجال الاعتماد المستندي فيكون

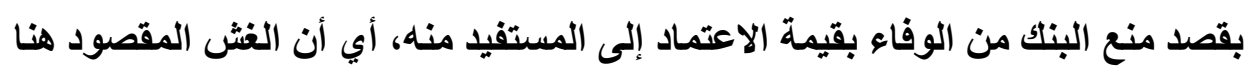
هو الذي يحدث في مرحلة تنفيذ الاعتماد وليس وقت إبرامه. أما الأعراف الدولية الموحدة للاعتمـادات المستتدية فلم تثنـاول الغش الموجب لتعطيل مبدأ الاستقلال بين التزام البنك بالدفع وبين عقد الأساس ومنع البنك من الدفع، 
و وإنما ذكرت فقط حالات من الغش التي تعفي البنك من المسئولية إذا ثبت غش المستفيد

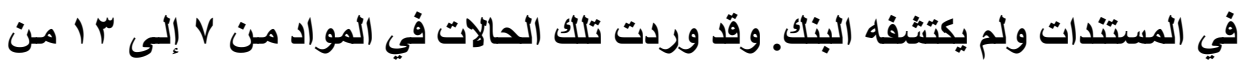

وفيما يتعلق باتفاقية الأمم المتحدة بثأن الكفالات المستقلة وخطابات الضمان

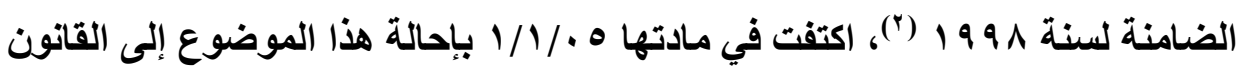

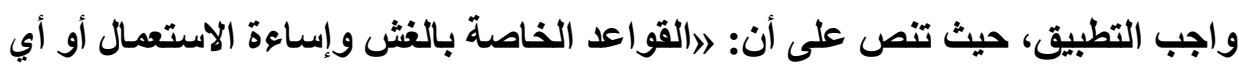
أمر مماثل غير خاضعة لأحكام الاتفاقية، ويترك أمر تنظيمها إلى القانون واجب التطاعل التطبيقها. وإزاء غياب تعريف للغش في مجال الاعتماد المستندي في أي تشريع أو أعراف

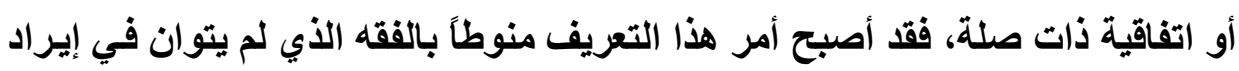
تعريف لله. وقد تعددت تلك التعريفات الفقهية: فقد عرفه البعض ( • V مكرر) بأنه النقض الفاحش من المستفيل لالتزامها وفق الاعتماد . (الماد

ونكون أمام حالة غش من البائع في الاعتمساد المستندي إذا قدم مستندات كاملـة

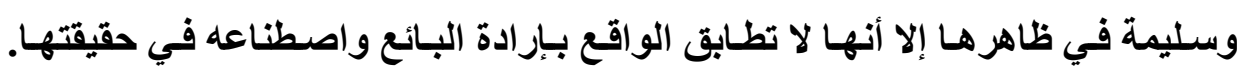

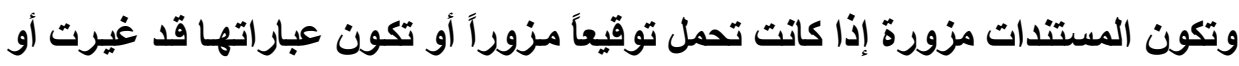

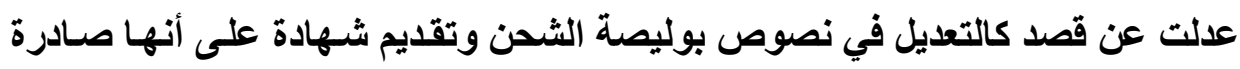

(1) Khaled Kanan, fraude cohesion IBLJ. No. 6.

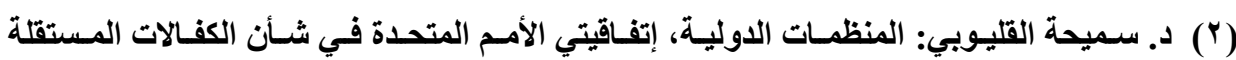

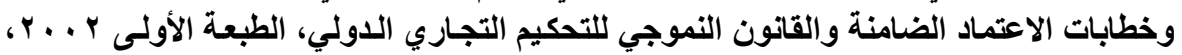

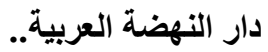

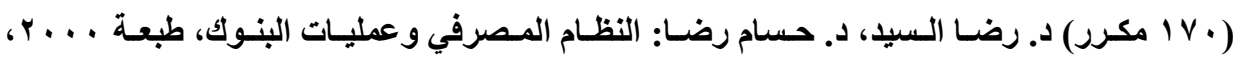
ص ص صrrا، دار النهضة العربية، القاهرة. 
عن سلطة عامة معينة مع أنها صادرة عن شخص غير ذي صفة. ففي مثل هذه الحالات

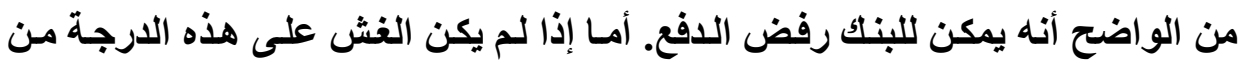
الوضوح فيمكن اللجوء إلى القضاء للحصول على أمر بمنع الدفع.

كما عرف البعض الغش في الاعتماد المستندي بأنه كل عمل من جانب المستفيد يقصد به الحصول على مزية الاعتماد بطريق الغش. ويجب أن يقتصر الغش في عمل هل المستفيد نفسه فلا يشمل الغش الصادر من الغير إذ يعتبر المستفيد بريئًا منه('). وقد يستخدم الغش بمعنى أوسع بأنه سلوك غير شريف مقترن بدرجة من الخداع

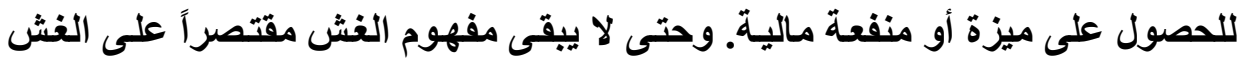
الصادر من المستفيد فإن البعض يرى أن الغش هو عدم صدق المستتدات أياً كان سبيه أو المتسبب فيه ولا عبرة إلا بالواقع ().

والغش في الاعتماد المستتدي يمكن أن يطول وثائق الاعتمـاد بالكامل كبوليصة

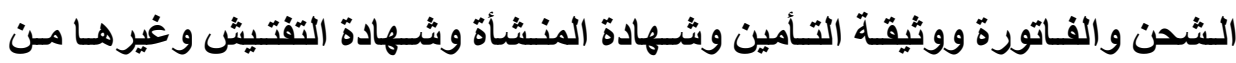
الوثائق. إلا أن الغش في بوليصة الشحن يحظى بالنصيب الأكبر، وذلك كنكر بضائع

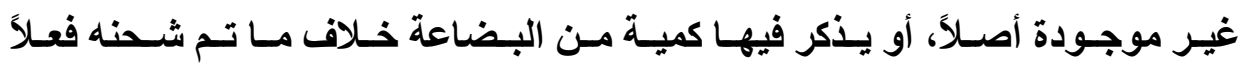
كشحن نفايـات بـلاًا من شحن البضاعة المذكورة في الوثيقة أو كمية أقل من الكمية المحددة) ("آ)

(1) د.على جمال الدين عوض: الاعتمـادات المصرفية وضماناتها، ؛ 99 1 ، ص ب ؛ ال، دار النهضة

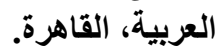

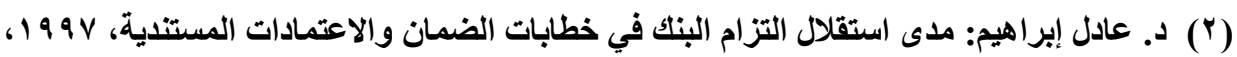

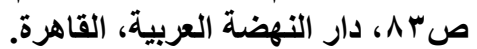

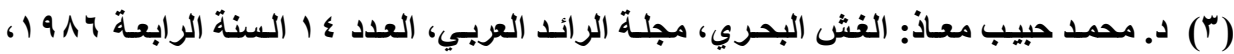


ويذلك يمكن أن نرى إجماع فقهي أو يكادوا أن يجمعوا على أن الغش هو تصرف سـلبي مـصدره أحــ الأطـراف المتعاقدة بنيـة الإضــرار مـع سـبق الإصـرار والإخـلال بالتزامات وحقوق مفروض احترامها والعمل وفق مقتضاها.

وعندما يكون المستتد قد اعتراه عيب الغش فإنـه يتجرد من كل أثر قانوني، فيكون المستند متجرداً من قيمته ويحق للمصرف رفضه. وبما أن بوليصة الشحن دليل

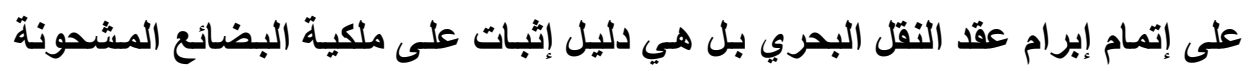

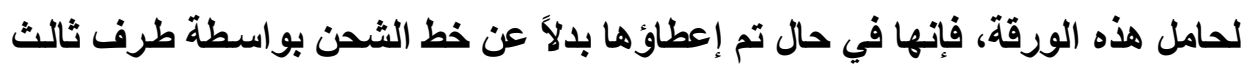

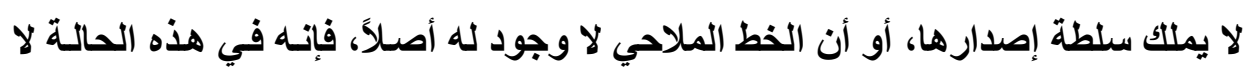

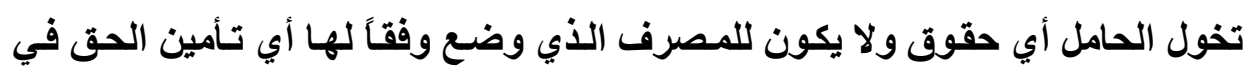

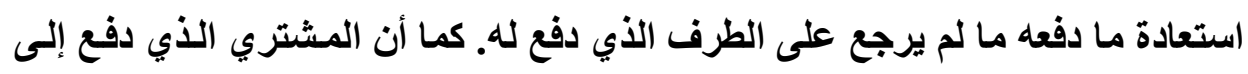
المصرف مصدر الاعتماد سوف يواجه مستثدات دون قيمة. وكذلك الأمر لو أن شـهادة فحص طلبت من وكيل فحص مسمى ونفذت من قبل شخص لا علاقة له بهذا الوكيل

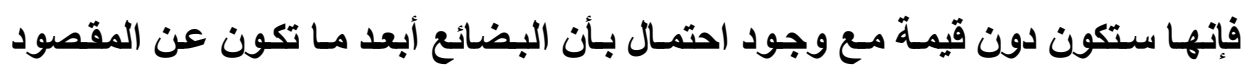

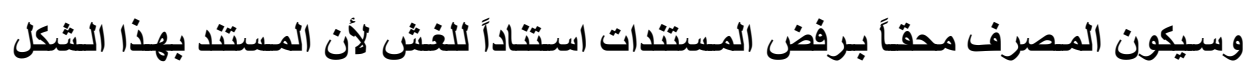

سيكون ورقاً لا قيمة له فهو ليس بوليصة شحن أو شهادة فحص لأنه مزور (') والواقع أن الاتجـاه السائد في معظم الـول، وبـصفة خاصـة الاتجـاه القضائي الفرنسي، وإن كان يقر التزام البنك بسداد مطالبة المستفيد وعدم الاعتداد باعتراضسات

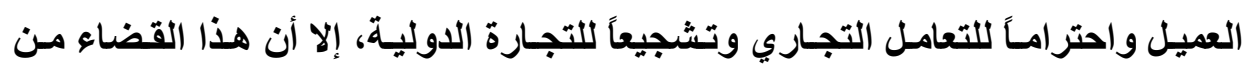

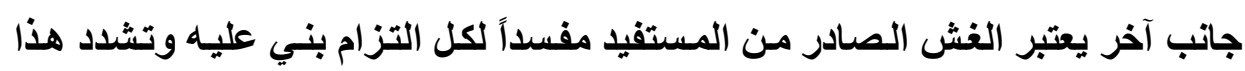
القضاء بأن يطلب ثبوت الغش بما لا يدع مجالاً للثك، والأي عبر عنه هذا القضاء بـأن

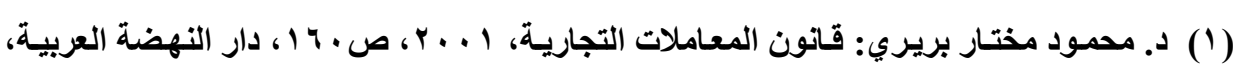


يكون واضحاً للعين، بمعنى أن مجرد الإدعاء بوجود الغش دون سند أكيد يحتاج إلى تحقيق فلا اثر له على استقلال التزام المصرف في السداد عند تقديم المستندات ('). وإن كان هناك رأي واسع في الفقه وهو (الغش يفسد كل شيء)، بمعنى استبعاد التزام المصرف عند توافر الغش .

الواضـح مـن كل هذه التعريفـات أنهـا ربطت بين المستتدات والبضاعة للقول بوجود غش من عدمه. فإذا كـان المدون في المستتدات من بيانـات ومعلومـات لا يعبر عن حقيقة البضاعة فيكون هناك غش في الاعتماد المستندي. والحقيقة أن هذا الربط بين المستتدات والبضاعة لإثبات الغش يتنافي مـع جوهر وفلسفة الاعتماد المستندي الذي يرتبط تنفيذه بالمستندات فقط وليس بالبضاعة، حيث لإبـ

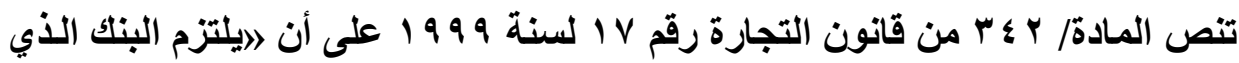
فتح الاعتماد بتنفيذ شروط الوفاء والقبول والخصم المتفق عليها في عقد فتح الاعتمـاد

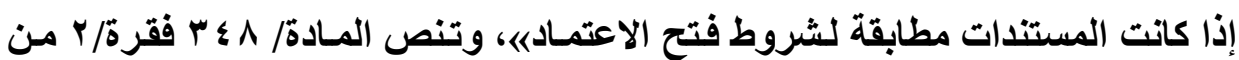
ذات القانون على أن: اولا يتحمل البنك أي التزام يتعلق بالبضاعة التي فتح الاعتمـاد

بسبيهاء.

وعلى ذلك فإن أحكام الاعتمـاد المستثدي تأبى الربط بين المستتدات والبضاعة

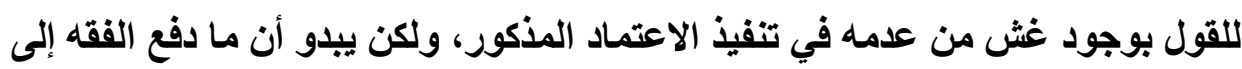
هذا الربط في تعريفه للفش في الاعتمـاد المستندي هو ازديـاد اللجوء إلى الممارسـات

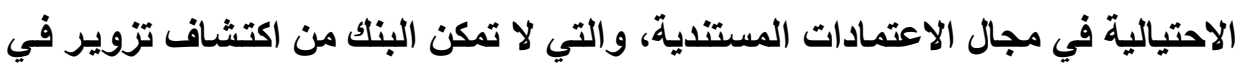

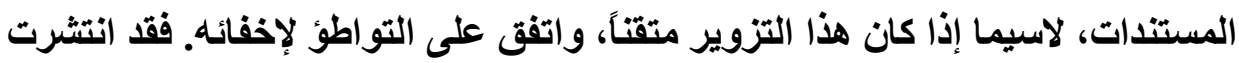

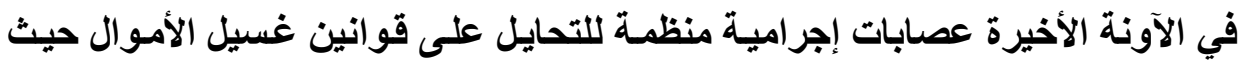


يتآمر المورد والمستورد على تقديم مستتدات تتطوي على احتيـال بمـا يخص بضائع غير موجـودة، ويفحص البنـك المستتدات ويتأكد مـن سـلامتها وصـتهـا ومطابقتهـا ظاهرياً ويدفع من ثم قيمة الاعتماد، دون أن يكون هناك أي شكوى من أي طرف، الأمر

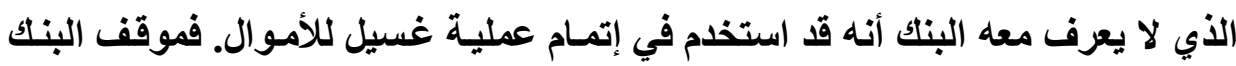

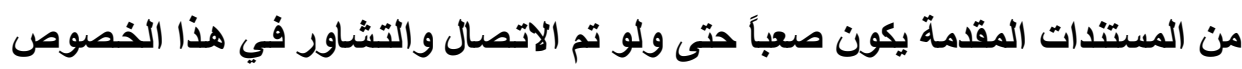
مع العميل المتواطئ. لذلك فإن موقف البنك من المستندات، واكتشاف تزويرهـا من فئ عدمه يجب أن يتم وفقاً للواقع، أي وفقاً للمطابقة بين المستندات والبضاعة التي تمثلها

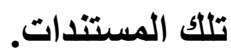

ويمكن أيضاً تبرير مسلك الفقه في تعريف الفش بـالربط بين المستتدات وحقيقة

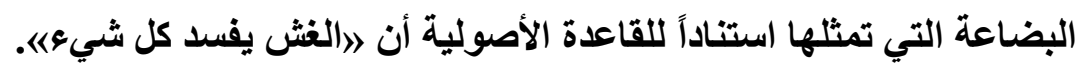
Y ب - شروط الغش وصوره: سنمهر للحديث عن شروط الغش في مجـال الاعتمـاد المستتدي وصوره بعرض بعض الأحكام التي صدرت في بعض الدول العربية، خصوصاً في المغرب ومصر، والتي صدرت من محكمة النقض الفرنسية. فقد صدر حكم من محكمة الاستئناف التجارية، بالدار البيضاء بالمملكة المغربية

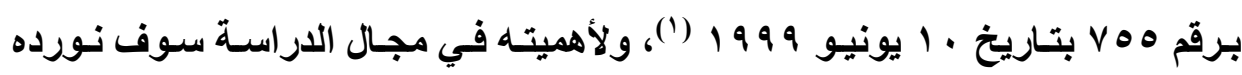
نصاً:

(1) هذا الحكم مشار إليه في مقالة للقاضي الدكتور/ يوسف بنباصر ، منشورة في الموسوعة القانونية

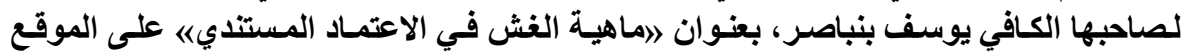
الإكتروني benbaceryousef@meneara.ma 
”... حيث إن كنه النزاع يتلخص في كون شركة سينومار فتحت اعتمـاداً مستتدياً

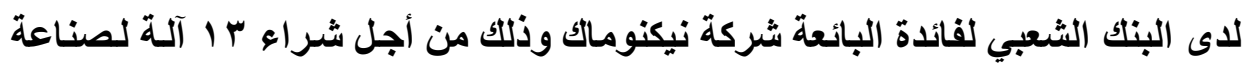

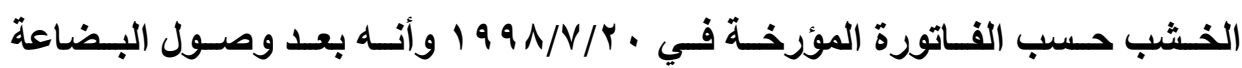
استصدرت أمراً بتعيين الخبير السيد: هـ سه أنجز تقريراً في الموضوع خلص فيه إلى ألى

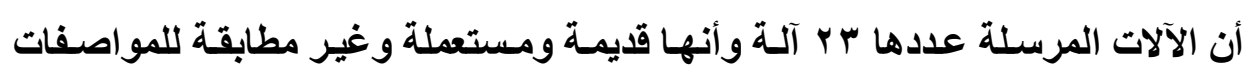

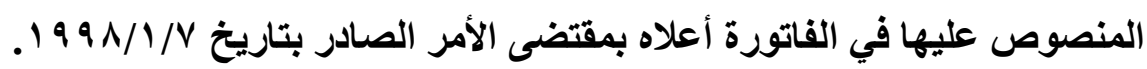
وحيث أن البنك الثعبي تمسك في استئنافه برفع الحجز المذكور على أسـاس أن عقد الاعتماد المستندي مستقل عن عقد البيع، وأنه أجنبي عن النزاع القائم بين البائع

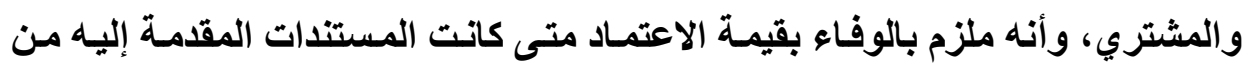

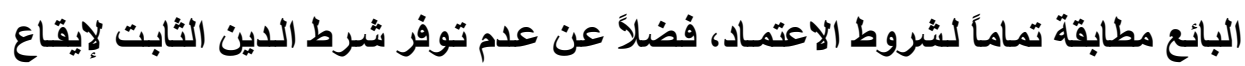

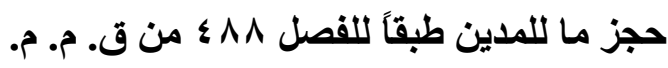
حيث أن الثابت مـن ظـاهر الوثائق المـلى بها مـن قبل الطرفين وكذلك تقرير الخبير السيد "هـ. ح" أن الآلات المرسـلة من طرف البائعة المستفيدة مـن الاعتمـاد

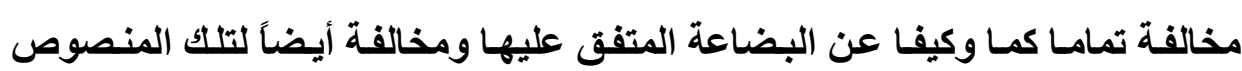

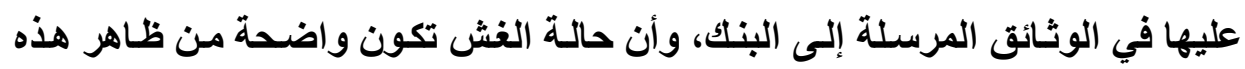
الوثائق.

وحيث أنه إذا كانت مقتضيات المادة V من القواعد والعادات الموحدة للاعتمادات المستندية تنص على أن البنك المنشئ للاعتماد المستندي لا يتحمل أيـة مسؤولية عن من العيوب التي تشوب البضاعة، إذا كانـت المستئدات التـي توصـل بهـا مطابقـة تمامـاً

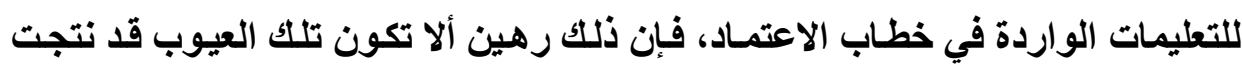

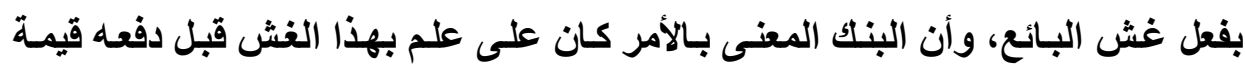
الاعتماد (راجع في هذا الصدد كتاب العقود البنكية للاكتور/ محمد الفروجي، صفحة 
• ع ب) الأمر الذي هو متوفر في النازلة ويتعين معه بالتالي رد الدفع بكون البنك ملزم بالوفاء متى كانت المستندات المقدمة إلى البنك من البائع مطابقة لشروط الاعتئ لاعتماد. وحيث إنه لا جدال في أنها يحق للمشتري الذي فتح إعتمـاداً مستتدياً قطعياً أن يجري حجزاً على هذا الاعتماد عند إثباته عدم قيام البائع بتنفيذ التزاماته وفق الاتفـاق المبرم بين الطرفين لأن من شـأن تنفيذه لالتزامه والقيام بالوفاء للمستفيد من الاعتمـاد،

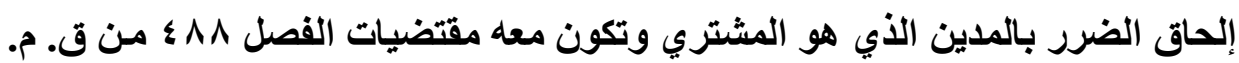
م. متوفرة في النازلة بسبب مديونية البائع لما ذكره أعلاه.

وحيث أنـه بـذلك يكون الأمر الاستـعجالي فيمـا قضى بـه مصادف للصواب، ممـا يتعين تأييده بهذا الخصوص مع تحميل الصائر للطاعن. وعملاً بأحكام المواد: • و ـ 1 و 1 من قانون أحداث المحاكم التجارية: لوهذه الأسباب فِإن محكمة الاستئناف التجاريـة بالبيضاء، وهي تبث انتهائياً علنيـاً وحضورياً تصرح: في الشكل: قبول الاستئناف. في الجوهر: برده وتأييد الأمر الاستعجالي الصادر.... ونـذكر مـن القضاء القرنسي بعض الحيثيات مـن حكم محكمة النقض الصادر بتاريخ r ديسمبر ع Y V I (') فقد قضت المحكمة في هذا الحكم بأن: |البنك لا يسأل عن تنفيذ الاعتماد ولو اتضح أن البضاعة غير مطابقة للمستثات الواردة بخطاب فتح الاعتماد، إلا إذا كان هناك غش من البائع وكان البنك يعلمه...ب؛. (1) مشار إليه لاى د. يوسف بنباصر، المرجع السابق، ص • 1، ص 1 . 
اليرتكب غشاً المستفيد الذي يقدم إلى البنـك شـهادات مراقبـة لا تحمل توقيع

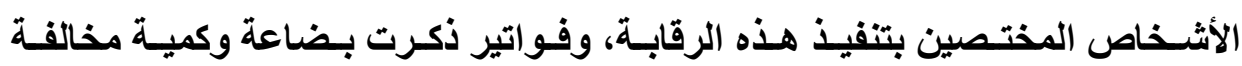

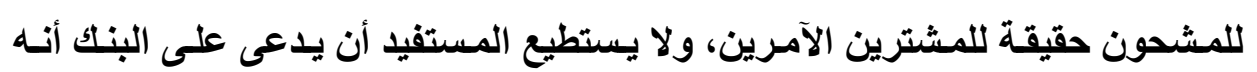

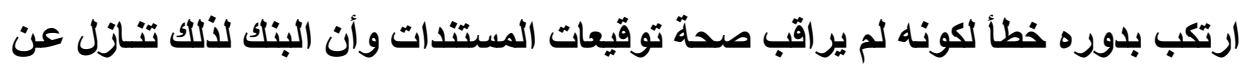
حقه في الرجوع عليه حنى دفع لله بدون تحفظ...٪.

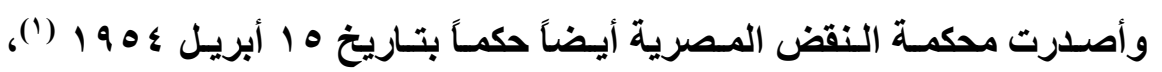
قضت فيه بأن:

الالبـائع خـالف شـروط الاعتمـاد بـأن شــن البــاعة مـن مينـاء غيـر المينـاء المنصوص عليـه في تلك الشروط، وكـان الشرط الذي يحدد مينـاء الشحن هو مسن مئن الشروط التي يجب مراعاتها....٪. rـ محل الغش في الاعتماد المستندي وشخص مرتكبه: هناك شروط يجب توافرهـا في محل الغش ( أ ) وفي شخص مرتكبه (ب) لكي ينتج أثره في تعطيل مبدأ استقلال التزام البنك بدفع قيمة الاعتمـاد المشترى عن علاقة الأسساس. ( أ ) محل الفش في الاعتماد المستتدي: يمكن أن يكون الغش الموجب لتعطيل دفع قيمـة الاعتمـاد المستتدي في عقد الاعتماد المستندي ذاته (*) أو في عقد الأساس (*). 
قد يقع الفش في الاعتماد المستتدي ذاته وليس في البضاعة وهو مـا يطق عليه

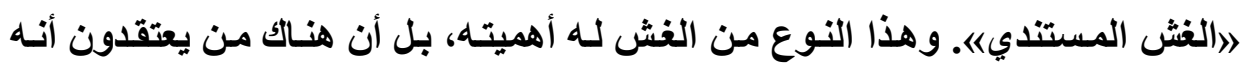

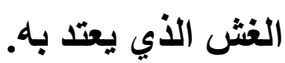

ويقصد بالغش المستندي تقديم مستندات مزورة أو احتيالية'(') و المستتد المزور

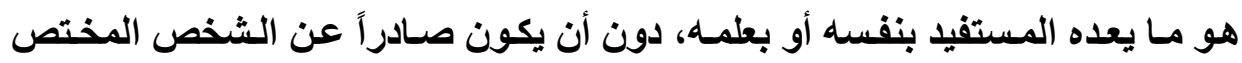
بإعداده، كأن يقوم المستفيد بتعبئة نموذج سند الثحن بنفسه ويوقع عليه بدلاً من ربان النيان

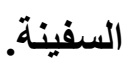

أما المستثد الاحتيالي فيقصد به ذلك المستثد الذي يعده الشخص المختص بذلك

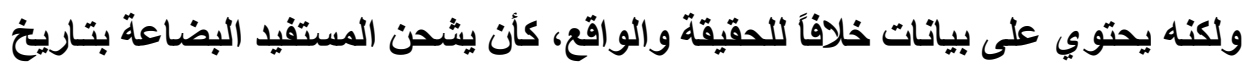

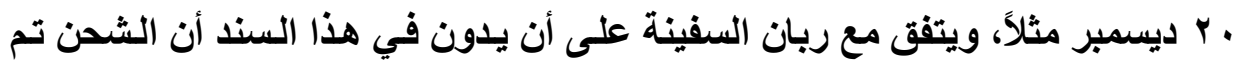

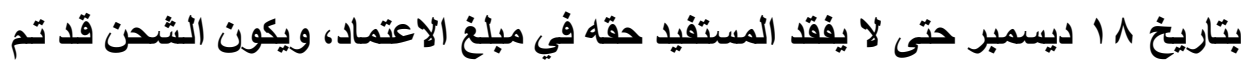

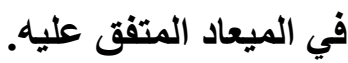
ويقع الغش المستندي أيضاً في بوليصة الشحن، وهي أهم مستندات النقل. فقد الندا تصدر من شخص لا يملك سلطة إصدارها أصلاً وليس من الخط الملاحي المعتمد. وقد لا يكون الخط الملاحي المدون في بوليصة الشحن غير موجود أصلاً. كذلك الأمسر

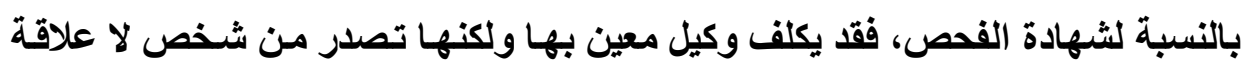

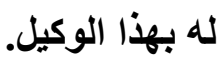


ففي كل هذه الفروض يحق للبنك الفاتح رفض هذه المستندات استناداً إلى الغش، لأن المستتدات في تلك الحالات ستكون ورقاً لا قيمة له. إلا أن اكتشاف الغش المستندي قد يكون صعباً بالنسبة للبنك إذا كـان التزوير الأي شابه متقناً.

$$
\text { ("الغش في عقد الأساس (الغش في البضاعة): }
$$

ويعتبر غشاً في عقد الأساس الغش المادي المتعلق بالبضاعة موضوع هذا العقد. فقد يتعاقد المستورد علي صفقه ساعات ثم يكتثف أن البضاعة عبارة عن "حجارة" بلاًا من الساعات. وقد يتفق المستورد مع المورد علي توريـ كميـة من الورق ويتبين بعد الثحن أن البضاعة عبارة عن قمامة ومواد لا قيمة لها. وقد استقر القضاء المقـارن علـي أن الفش الواقع في عقد الأسـاس والمتعلق بالبضاعة، والغش المستتدي الواقع في الاعتمـاد ذاته، كلاهمـا يقضي علـي أن مبدأ استقلال التزام البنك بدفع قيمة الاعتماد ويمنع البنك من الدفع. (ب) شخص مرتكب الغش في الاعتماد المستندي: قد يصدر الغش في الاعتماد المستندي من المستفيد من الاعتماد (*)، وقد يكون

$$
\text { نتيجة تواطؤ بين المورد والمستورد (*). }
$$$$
\text { صدور الغش من المستفيا (المورد): }
$$

قـ يقدم المستفيد من الاعتماد إلى البنك مستندات سليمة في ظاهرها، ولكنها في حقيقتها مزورة تزويراً متقتاً بهدف خداع البنك وإيهامسه. وقد يقوم المستفيد (المورد) بإرسال بضاعة إلى المستورد (العميل الآمر) غير مطابقة للمواصفات المتفق عليها بينهما في عقد الأساس، ويعلم المورد بذلك. وقد لا يصدر الغش مـن المستقيا ولكنـه

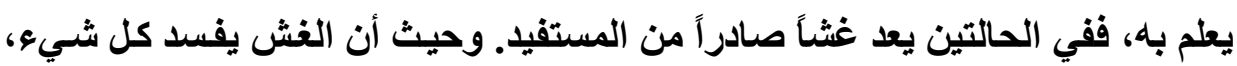


فمن حق البنك الامتناع عن الافع باعتبار أن هذا الغث يمثل استثناء على مبدأ استقلال التزام البنك بالدفع عن علاقة الأساس. (*) صدور الفش بالتواطؤ بين المورد (المستفيد) والمستورد (العميل الآمر): قد يتآمر طرفاً عقد الأساس على تقديم مستتدات تنطوي على احتيـال بمـا يخص بضاعة غير موجودة أو غير مطابقة للمواصفات. ويقوم البنـك بفحص المستندات، ونظراً لعدم وجود شكوى من أي من طرفيه بتزوير المستتدات، فِان البنك لن يستطيع أن يعلم بهذا التزوير. ولن يفيده في هذا الخصوص إرسال المستندات للمستورد (العميل

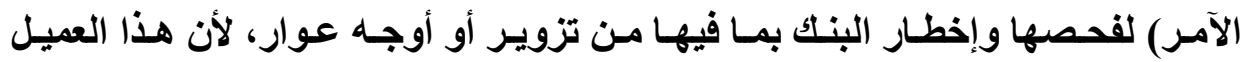
متواطئ مع المستفيد من الاعتماد (المورد). إلا أن الغش الصادر بالتواطؤ بين العميل الآمر والمستفيد، لن يتم اللجوء إليه في

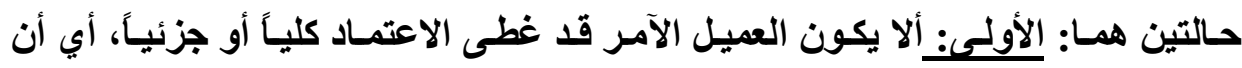

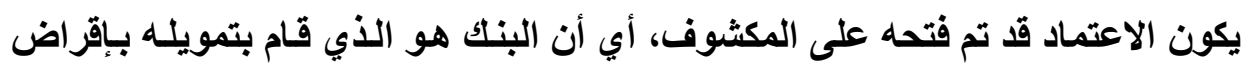
العميل الآمر غطاء هذا الاعتماد. فقي هذا الفرض يكون للغش بـالتواطؤ بين الطرفين

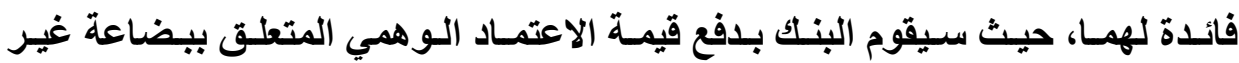
موجودة أو غير مطابقة للمواصفات للمستفيد، الذي يقوم بدوره باقتسامه مـع العميل الآمر. فالبنك في هذه الحالة وقع فريسة لطرفي عقد الأساس، واستعمل كوسيلة لغسيل

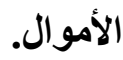

أما إذا تعلق الأمر باعتماد مغطى بالكامل فإنها يصعب حدوث تواطؤ بين المستفيد والعميل الآمر، حيث أن العميل الآمر لن يتآمر مـع المستفيد للاحتيال على البنك، لأن هذا العميل الآمر قد سبق وغطى قيمة الاعتماد بالكامل من أمواله الخاصة ويهمـه إتمـام عملية الاعتماد أو استرداد هذا الغطاء. 
الثانية: أن يكون الغش متعلقاً بعقد الأسساس أي بالبضاعة، وليس غثاً مستندياً.

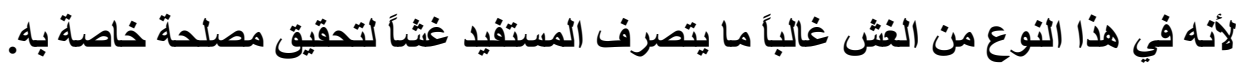

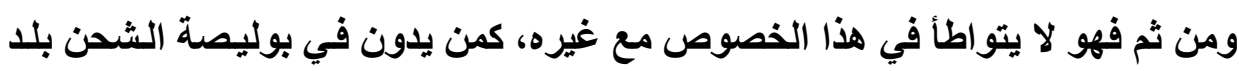

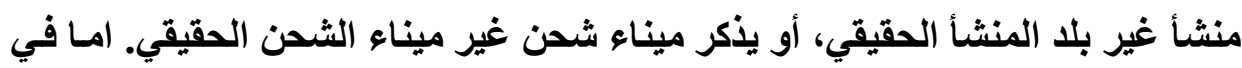

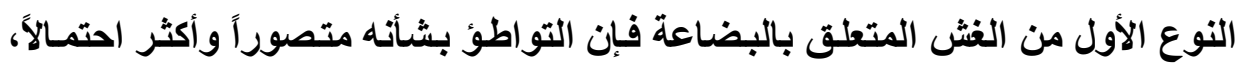

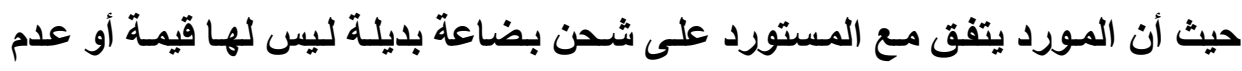

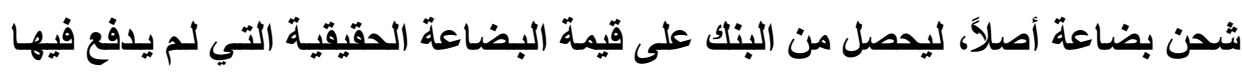
تمناً أو دفع ثمناً تافهاً، ويقتسم تلتك القيمة مع المستورد (العميل الآمر).

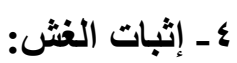
يمثل الفش استثناء هاماً على استقلال التزام البنتك بدفع قيمة الاعتماد عن عقد

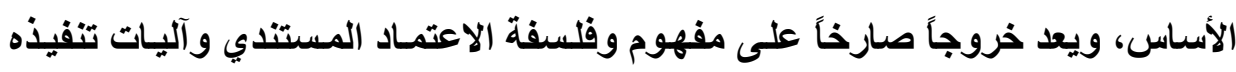

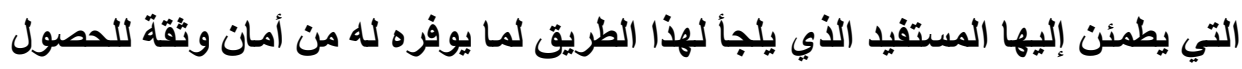

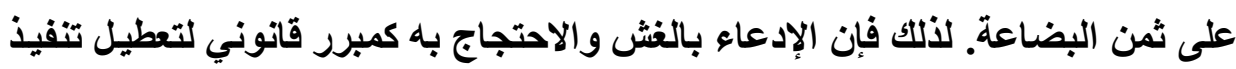

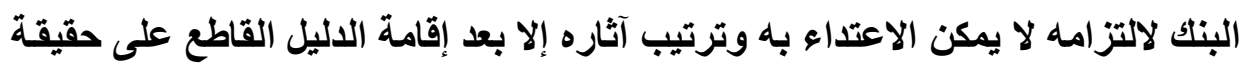

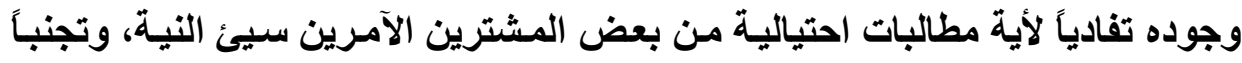

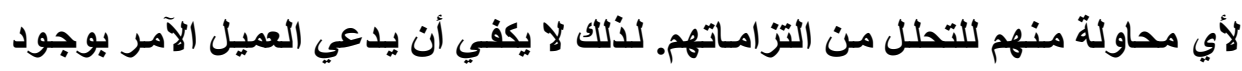

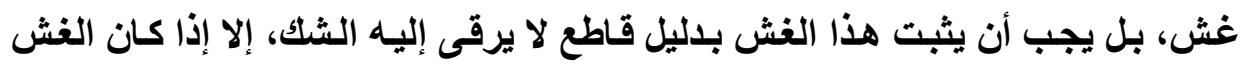
واضحاً يفقاً العينين كما ذهبت بعض أحكام القضاء (').

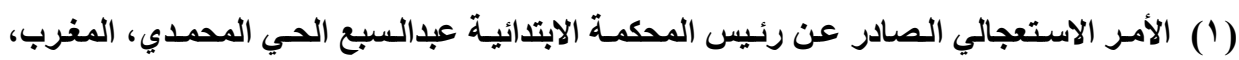

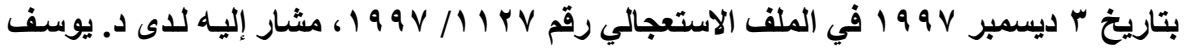

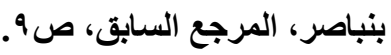


أما إذا كان الغش ليس بهذا الوضوح، فما هي وسيلة إثباته، هل يكفي تقرير

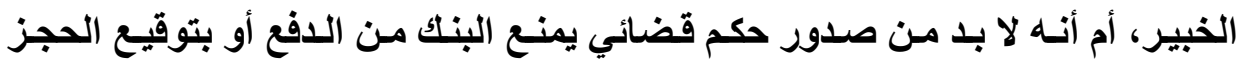
التحفظي على قيمة الاعتماد المستندي (') ذهب رأي إلى انه يكفي تقرير الخبير، وذهب رأي آخر إلى أنه لا بـ من صدور

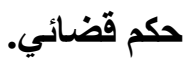
ونحن هنا نرى التفرقة بين أمرين: إذا كان الأمر منظوراً أمسام القضاء وانتدب

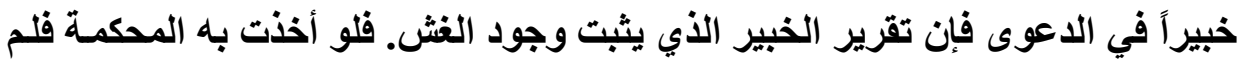

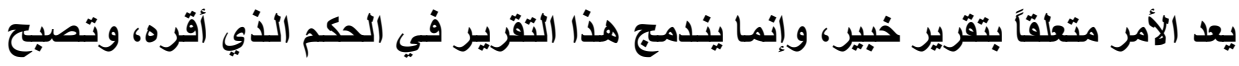

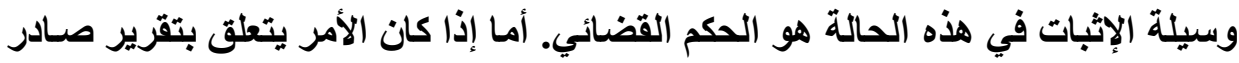
من مصلحة الجمارك، التي تكتثف الفش عند الإفراج عن البضاعة محل عقد الأسساس، فإن وسيلة إثبات الفش في تلك الحالة هو تقرير الخبير وليس حكم القضاء. وسواء تعلق الأمر بتقرير خبير أم بحكم قضائي، فإنتا نرى أن أي من هـاتين الوسيلتين كافِ لإثبات الغش الذي يمنع البنك من الوفاء بقيمة الاعتمـاد المستثندي،

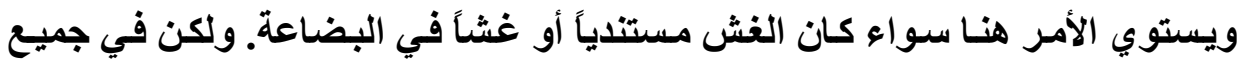

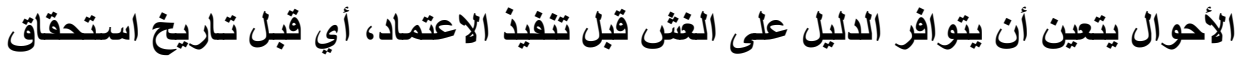
مبلغ الاعتماد، وقبل الدفع أو قبل المرحلة النهائية لتنفيذ الاعتماد إذا نفذ على مراحل. وتجدر الإشارة إلى أن إقامة الدليل على الغش، خصوصاً الغش في البضاعة، لا

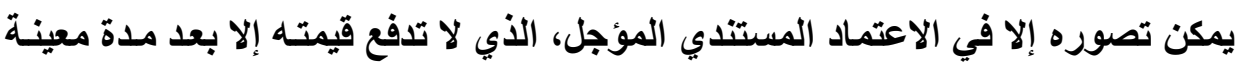

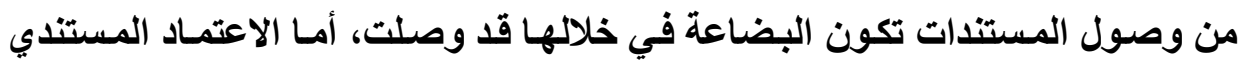


المعجل الأي تدفع قيمته بمجرد وصول المستتدات وليس بعد مدة معينة من وصولها،

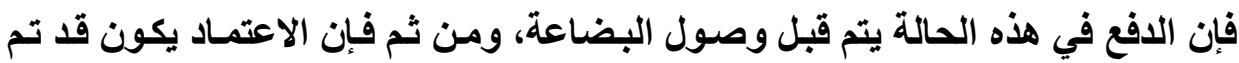
تنفيذه قبل طلب وسيلة إثبات حالة البضاعة لأنها في هذا التوقيت لم تكن قد وصلت بعد. أما إقامة الدليل على الغش المستتدي فيمكن أن يتم قبل وصول البضاعة، لأن المستندات تصل إلى البنك من المستفيد عادة قبل أن تصل البضاعة.

وذهب اتجـاه في الفقـه(') أن معظم البنـوك الأمريكيـة لـدى استلامها مستتدات تتباين جوهريـاً مـع شروط خطاب فتح الاعتمـاد، تقوم بتوجيه إخطار إلى طالب فتح الاعتماد، ويأخذ هذا الإخطار شكل خطاب مسجل بعلم الوصول، تدون فيه المخالفـات الواردة في المستندات وتطلب منـه الإطلاع عليها وإصدار تعليماتـه بالدفع من عدمـه،

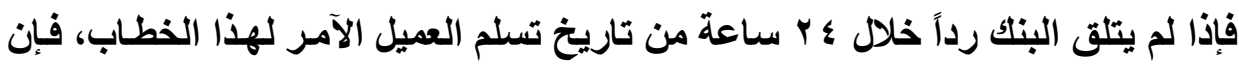
البنك يخطر المستفيل أو بنكه أن المخالفات الموجودة في المستندات لا تسمح لـه بـدفع

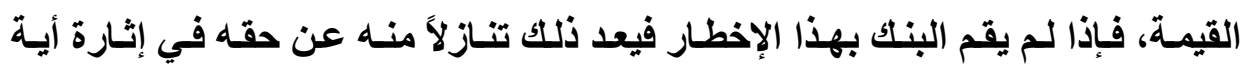
اعتر اضات لرفض الافع (؟). وهكذا فإنـه إنـارة مسألة الغش في الاعتمـاد المستندي يمكن أن تتم من العميل الآمر (المستورد) أو من البنك الفاتح نفسه أو من البنك المتدخل.

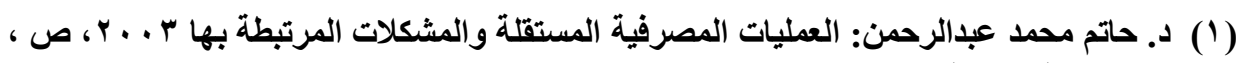
دار النهضة العربية، القاهرة. (r) د. على جمال الدين: الاعتمادات المستتدية، 19191، ص ، د دار النهضة العربية. 


\section{المبحث الثاني \\ علاقات خطاب الضهان واستقلاها}

تناول المشرع المصري تنظيم أحكام خطاب الضمان في المواد من هـ ب إلى

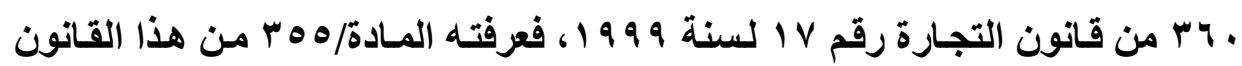
بأنه تعهد مكتوب يصدر من البنك بناء على طلب شخص يسمى الآمر، بدفع مبلغن معين

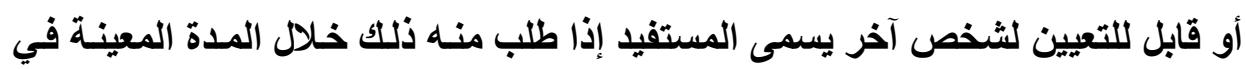

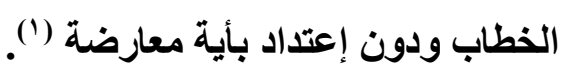
فـأطر اف خطـاب الضمان وفقـاً لهـا التعريف ثلاثنة هـم: البنك مـصدر الخطـاب، والعميل الآمر بإصدار الخطاب، والمستفيد منه، وقد يتدخل بنك ثان لضمان تتفيذ التزام البنك المصدر، ويصبح هو البنك الضامن الأصلي ويتحول البنـك المصدر إلى ضـامن مقابل، فيكون أطراف الخطاب في هذه الحالة أربعة. ويترتب على تعدد أطراف خطاب الضمان تعدد العلاقـات الناشئة عنه (المطلب الأول). وتلك العلاقات، رغم ارتباطها، مستقلة من حيث المبدأ، عن بعضها البعض

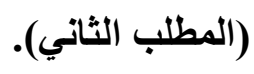




\section{المطلب الأول \\ علاقات خطاب الضشمان}

تنشأ، من حيث الأصل، عدة علاقات من خطاب الضمان إذا كانت أطرافه ثلاثثة (الفرع الأول) وتزداد تلك العلاقات تعدداً عندما يتدخل بنك ثان في حالة الضمان المقابل (الفرع الثاني).

\section{الفرع الأول}

\section{علاقات خطاب الضهمان إذا كان ثلاثي الأطراف}

قبـل الاسترسـال في شـرح العلاقـات الناثـئة عن خطساب الضمان عندما تكون أطر افه ثلاثة، هناك ملاحظة مبدأيه يتعين إبداءها فيمـا يخص الفرق بين هذه التهات العلاقـات وتلك التي تنشأ عن الاعتمـاد المستندي. فخطسب الضمان يصدر لتغطيـة أخطار غير محدودة، عقدية كاتت أو غير عقدية، على عكس الاعتماد المستتدي فيتم فتحه بمناسبة

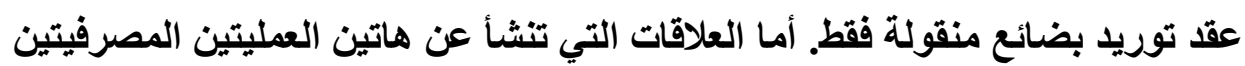

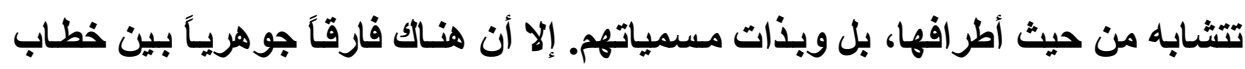
الضمان والاعتماد المستندي يلقي بظلاله بالتأكيد على محتوى ومضمون تلك العلاقات، لاسيما فيما يتعلق بالاستثناءات الواردة على استقلالها عن بعضها البعض، وهو أن الن قيمة خطاب الضمان يتم دفعها لاى أول مطالبة من المستفيد الذي لا يلتزم بتقديم أيـة

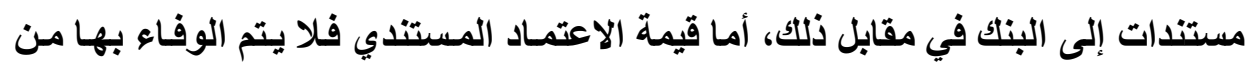
قبل البنك الفاتع إلا إذا قدم إليـه المستفيد المستتدات المتفق عليهـا، وبعد التأكد من سلامتها وصحتها ومطابقتها ظاهرياً. فقيمة الاعتماد تدفع مقابل المستتدات. وأنواع خطابات الضمان عديدة لا تقع تحت حصر، إذا أنها تختلف بـاختلاف نوع الخطر الذي صدر الخطاب لتظطيته، فهناك على سبيل المثال خطاب الضمان الابتدائي 
وخطـاب الضمان النهائي، وخطاب ضـمان حسن التنفيذ، وخطـاب الضمان الملاحي، وخطاب الضمان الجمركي، وخطاب الضمان المقابل.

وأياً كان نوع الخطاب فالعلاقات التي تنشأ بين أطر افه واحدة، وتتمثل فيما يأتي:

أولاً: العلاقة بين العميل الآمر والمستقيد:

تنشأ العلاقة بين العميل الآمر والمستفيد قبل إصدار خطاب الضمان، ويحكمها العلاقة التي تربط بينهما والتي صدر الخطاب بسببها('). وتتضمن هذه العلاقة، التي قد التدان

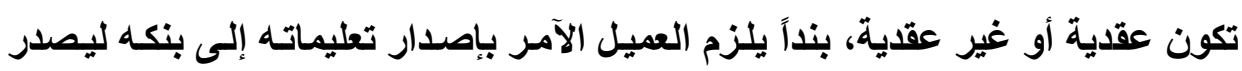

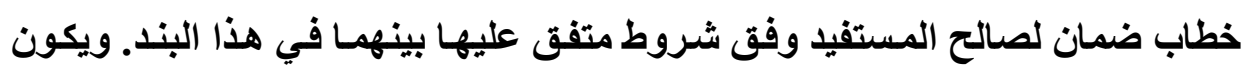
العميل الآمر في تلك العلاقة، والذي تختلف صفته ومسماه حسب نوع هذه العلاقة، هو المدين، ويكون المستفيا هو الدائن، والذي أيضاً يختلف اسمه في العلاقة المذكورة. وتسمى العلاقة التي تربط العميل الآمر بالمستفيد علاقة الأساس، وتتحدد حقوق

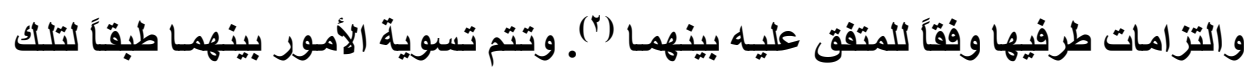
العلاقة حتى بعد قيام البنك بدفع قيمـة خطاب الضمان، فهي المرجع النهائي للطرفين. فكما سنرى لاحقاً. فهذه العلاقة لا تستقل عن خطاب الضمان بالنسبة لحقوق والتزامـات

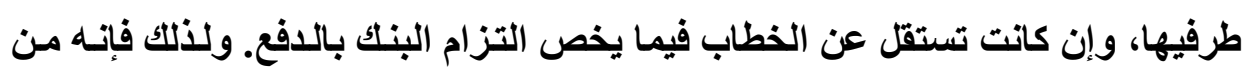
الأفضل والأدق القول أن التزام البنك بدفع قيمة خطاب الضمان هو المستقل عن خطـاب الضمان، وليس القول أن خطاب الضمان يستقل عن علاقة الأساس.

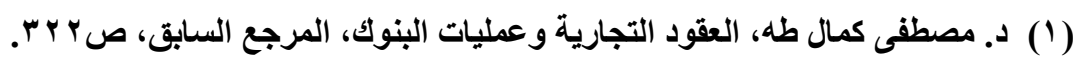

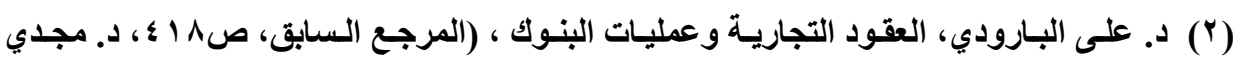

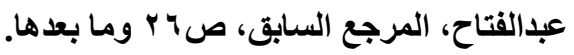


فقد يقوم البنك بدفع قيمة الخطاب ثم ينازع العميل الآمر في أحقية المستفيد في مبلغ الخطاب، فيرجع عليه، وليس على البنك، لاسترداد مـا قبضه على أسـاس الدفع غير المستحق، ويتم هذا الرجوع وفقاً لبنود علاقة الأسـاس، حيث سيتحدد إخلال أي من الطرفين من عدمه بتنفيذ التزاماتهما على ضوء هذه العلاقة. ثنانياً: العلاقة بين العميل الآمر والبنك مصدر الخطاب: يتوجه العميل الآمر إلى البنك، إعمالاً لبند إصدار خطاب الضمان الوارد في علاقة

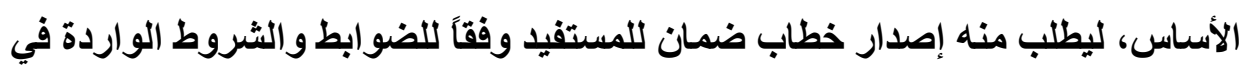
هذا البند، فيقوم البنك، تتفيذاً لأمر عميله، بإصدار الخطاب. وهذا هو عقد إصدار خطاب الضمان الذي يربط بين العميل الآمر والبنك، يتضمن مدة الخطاب ومبلغه وعملة الوفاء به. وهي ذات الشروط والضوابط المنصوص عليها في علاقة الأساس. وبالتالي فإن علاقة الأساس هي التي تؤدي إلى نشوء عقد إصدار الخطاب، فهي

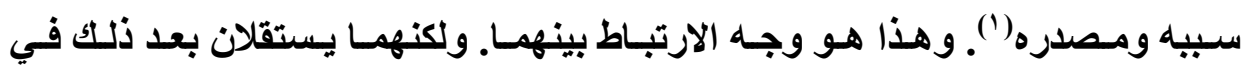

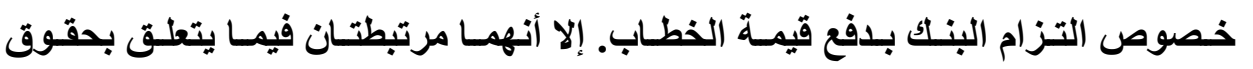
والتزامسات طرفي علاقة الأسـاس، حيث يتم تسوية العلاقة بينهما والناشئة عن عقد إصدار الخطاب وفقاً للبنود المتفق عليها في علاقة الأساس. ثالثًاً: علاقة البنك المصدر بالمستفيذ من الخطاب: بعد أن يقوم البتك باببرام عقد إصدار الخطاب مـع العميل الآمر، يخطر المستقيد بـأن هنـالك خطـاب ضـمان قد صـدر لصالحه بنـاء على تعليمـات العميل الآمـر، ويبلغـه 
بتفاصيل هذا العقد عن طريق خطـاب يوجهه إليه، هو خطاب إصدار خطاب الضمان. وخطاب التبليغ هو الذي يحكم العلاقة بين البنك المصدر والمستفيد (').

فخطاب إصدار الخطاب قد تم إبلاغه للمستقيد نفاذاً لعقد إصدار خطاب الضمان

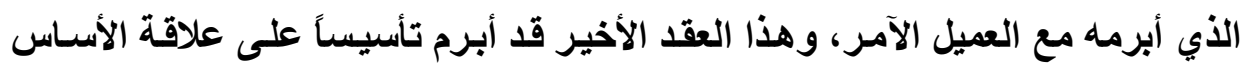
واستناداً إليها. وهكذا فتلك العلاقات الثلاث مرتبطة، فعلاقة الأسـاس أدت إلى العلاقة بين العميل الآمر والبنك، وتلك العلاقة الأخيرة أدت لنشوء العلاقة الثالثة بين البنك الثك المصدر والمستفيد. وهذه العلاقات الثلاث، رغم ارتباطها ببعضها بسبب وجود طرف قاسم مشترك، فالعميل الآمـر قاسم مشترك في علاقة الأسـاس وعقد إصدار الخطاب، والبنك المصدر قاسم مشترك في عقد إصدار الخطاب، وخطاب إصدار خطاب الضمان الموجـه للمستفيد، إلا أنهـا علاقـات مستقلة، ولا يجـوز التمسكك بـدفع يتعلق بإحداها وهاب

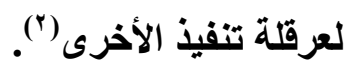

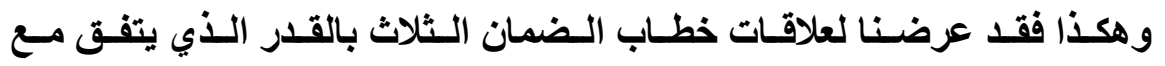
أحكام هذا الخطـاب مراعين في ذلك الفرق بينهـ وبين الاعتمـاد المستتدي، أمسا بـاقي تفاصيل هذه العلاقات فتتقق مع تفاصيل علاقات الاعتمـاد المستندي، فنحيل إليها منعاً

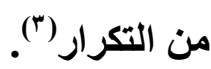

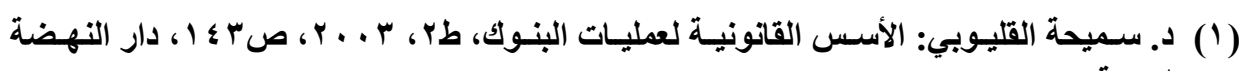
العربية.

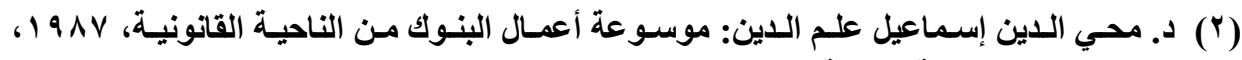
ص1^ \ه، دار النهضة العربية. انظر ما سبق ص ه1/ أوما بعدها. 


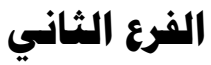 \\ علاقات خطاب الضهان إذا كان رباعي الأطراف}

قد يتدخل بنك ثان في خطاب الضمان فتصبح أطرافه أربعة. ويضاف بذلك علاقة

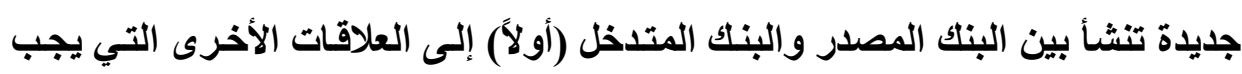
النظر إليها من منظور علاقة باقي أطراف الخطاب بالبنك المتلخل (ثُانياً). أولاً: علاقة البنك الضامن الأصلي بالبنك الضامن المقابل:

إن الضمان الناشسئ عن خطاب الضمان نوعان: الضمان المباشر: وفيه يصدر

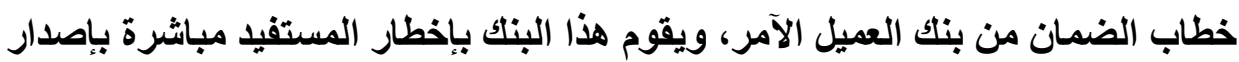

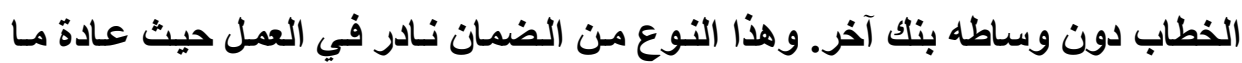
يفضل المستفيد أن يقوم بنك محلي في بلداه بتنفيذ عملية الضمان إنهان إمعاناً في حمايته.

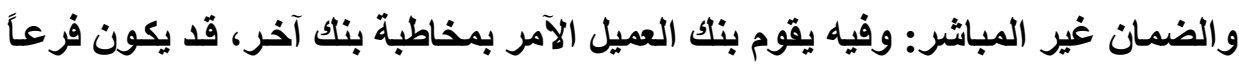
أو مراسلاً له، وقد يكون مستقلا عنه، ليصدر خطاب الضمان للمستفيد. وهنا يكون

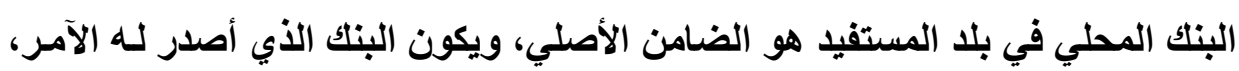
وهو بنك العميل الآمر، هو الضامن المقابل.

وفي هذا الفرض تكون عملية الضمان رباعية الأطراف: العميل الآمر، المستفيد، البنك الضامن الأصلي، البنك الضامن المقابل. ويرتبط الضمان الأصلي بالضمان المقابل ارتباطاً عضوياً، فإذا لم يطلب الضمان

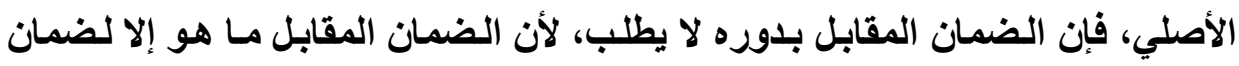

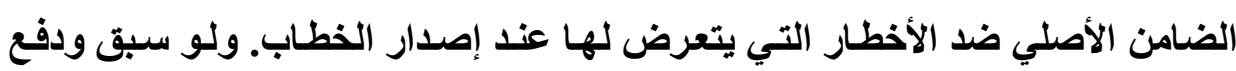

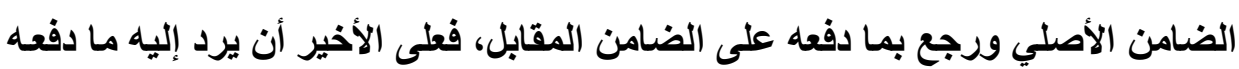

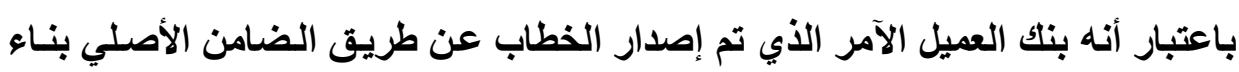


على تعليماته، فلا توجد علاقة مباشرة بين العميل الآمر والبنك الضامن الأصلي، وإنمـا توجد علاقة مباشرة بين العميل الآمر والضامن المقابل.

والعلاقة بين الضامن الأصلي والضامن المقابل هي علاقة وكالة، مثل العلاقة بين

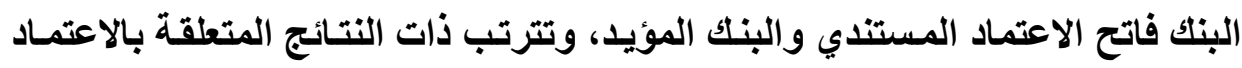

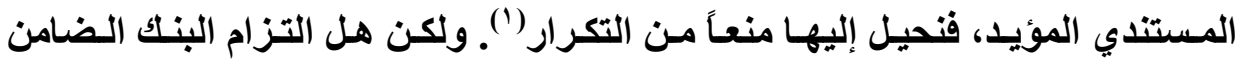

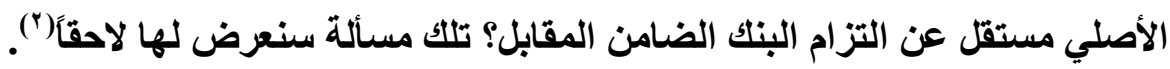
ثانياً: علاقة كل من العميل الآمر والمستفيد بالبنك الضامن الأصلي: في حالة تلخل بنك ثان في عملية خطاب الضمان لا توجد علاقة مباشرة بين هذا

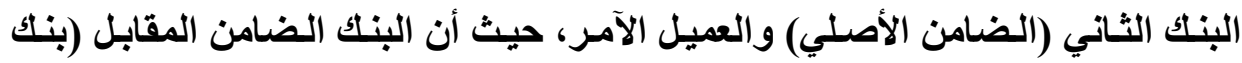
العميل الآمر) هو الذي يخاطب البنك الضامن الأصلي ليصدر خطاب الضمان لصالح المستفيد، وإن كاتت تلك المخاطبة تتم بناء على طلب العميل الآمر. أما بالنسبة للمستفيد فتوجد بينه وبين البنك الأصلي علاقة مباشرة، فهو الذي اختاره واشترط أن يكون في بلده. وهذا البنك هو الذي يخطر المستفيد بخطاب الضمان الأي أصدره لصالحه. ويرجع المستفيد مباشرة على البنك الضامن الأصلي لمطالبته بقيمة خطاب الضمان. 


\section{المطاب الثاني}

\section{هبدأ استقلال علاقات خطاب الضهمان واستثناءاتهه}

تستقل العلاقات الناشئة عن خطاب الضمان عن بعضها البعض من حيث الأصل (الفرع الأول)، إلا أن مبدأ استقلال تلك العلاقات تردعليه بعض الاستثناءعات، خصوصاً استقلال التزام البنك بدفع قيمة الاعتماد عن علاقة الأساس (الفرع الثاني).

\section{الفرع الأول}

\section{هبدأ استقلال علاقات خطاب الضهان(")}

رغم أن هنـاك ارتباطساً بين علاقـات خطـاب الضمان، إلا أنها مستقلة مـن حيث

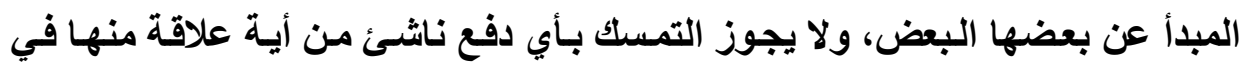
خصوص علاقة أخرى. ومن أهم العلاقات المستقلة تلك العلاقة بين خطساب الضمان وعلاقة الأساس، وخصوصاً استقلال التزام البنك بدفع قيمة الخطاب عن علاقة الأساس (أولاً)، واستقلال التزام البنك الضامن الأصلي عن التزام البنك الضامن المقابل (ثانياً). أولاً: استقلال التزام البنك عن علاقة الأسـاس:

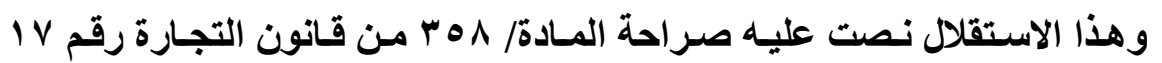

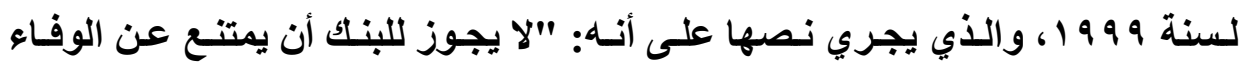
للمستفيد لسبب يرجع إلى علاقة البنك بالآمر أو إلى علاقة البنك بالمستفيد".

(1) حول مبأ الاستقلال استثناءاته بصفة عامة، انظر عادل إبراهيم السيد مصطفى، المرجع السابق،

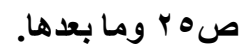

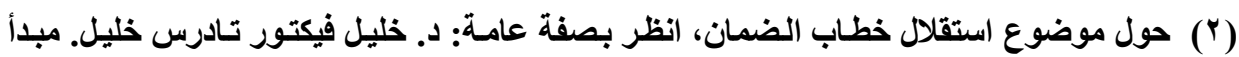
الاستقلال في خطاب الضمان الدولي وفقاً لاتفاقية الأمم المتحدة لعام

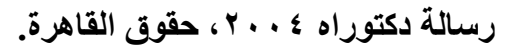


فوفقاً لهذه المادة فإن التزام البتك بالوفاء بقيمة الاعتماد مستقل عن عقد إصدار

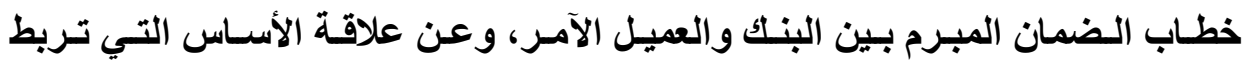

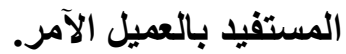

ويترتب على استقلال خطاب الضمان عن علاقة الأساس النتائج الآتية:

1- إن التزام البنك يقتصر على دفع مبلغ من النقود بمجرد طلب المستفيد، وذلك النك

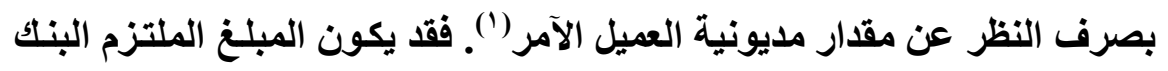
بدفعه أكبر أو أقل من تلك المديونية.

r - لا يستطيع البنك أن يدفع في مواجهة المستفيد بالدفوع الناشئة عن العيوب المتعلقة

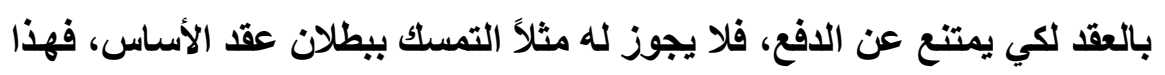

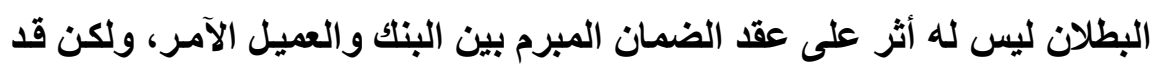

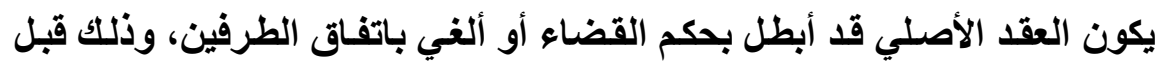

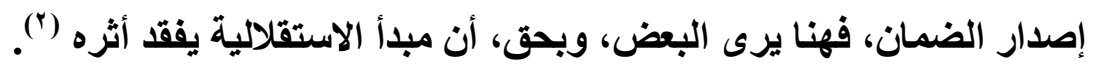

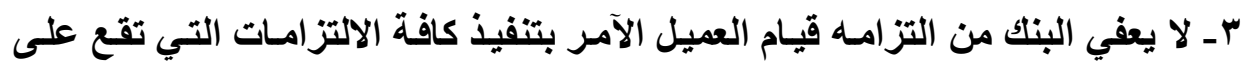

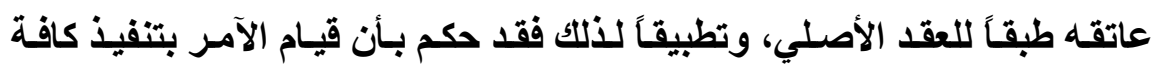

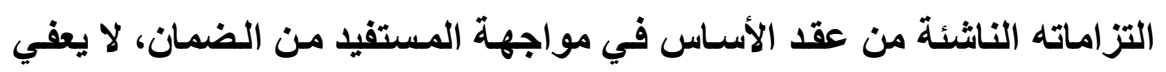
البنك الضامن من الدفع عند توجيه المطالبة إليه من المستفيد (")، بل أن القضاء الصناء

(1) VASSEUR, Droit et economie bancaire, Paris 1987, p.284.

(2) V. Cour d'appel de Paris 29 Janvier 1981, D. 1981. p. 336, note VASSEUR.

(3) Rive - Lange, garantie internationale ét caution, Banque 1987; p.11. etss. 
قد ذهب إلى ابعد من ذللك عندما قرر أن قيمـة الضمان يجب أن تدفع للدى الطلب حتى ولو أصبح تنفيذ العقد الأصلي مستحيلاً بفعل المستفيد.

ع ـ قـ يختلف القانون واجب التطبيق على كل من العقدين، حيث أن العقد الأصلي يمكن

أن يخضع لقانون مختلف عن ذلك الأي يخضع له الضمان تحت الطلب (')

هـ قد يختلف القاضـي المختص بنظر المنازعـات التي قد تنشأ من كل من العقدين،

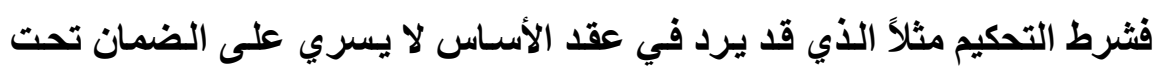

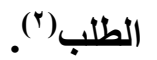

وكمـا أن خطساب الضمان مستقل عن عقد الأسـاس، فِإن التزام البنـك الضامن

الأصلي مستقل هو الآخر عن هذا العقد.

ثانياً: استقلال التزام البنك الضامن الأصلي عن التزام البنك الضامن المقابل: والسؤال الذي يثور الآن هو: هل كل من الضمان الأصلـي والضمان المقابـل

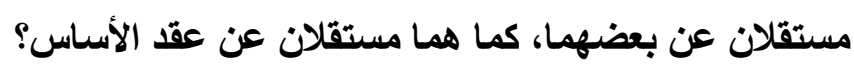

لقد قضت محكمة النقض الفرنسية في العديد من أحكامها بـأن الضمان الأصلي مستقل عن الضمان المقابل، واستخلصت من ذلك أن البنك الضامن المقابل إذا التزام

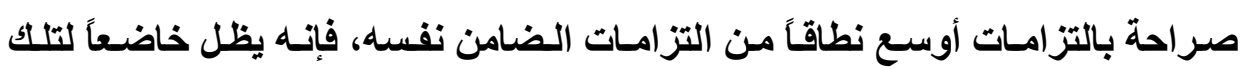

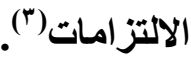

(1) Cass. Com 17 Janvier 1983., J. C. P. 1983. 11-19966 note J. Stoufflet.

(2) Cass. Com. 20 Nov 1985, Dalloz 1986, J. 213.

(3) Cass. Com 19 nov. 1985 Bull civ IV no 274, p.231. Cass. Com 5 Fev. 1985, Bull, Civ IV no 45 P. 38; Cass. Com 20 nov. 1985, = Dalloz 1986. J. 213, 3em esp, note vasseur; - Gavalda et stoufflet, chr. Dr. Bancaire, J. C. P. 1986, et. G. 1.3265 no 121. 
إلا أنـه في الحقيقة إذا تكلمنـا عن استقلال كل من هذين الضمانين عن علاقةـة

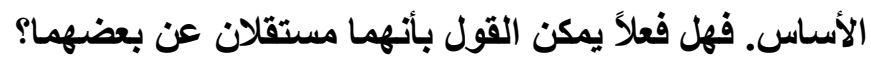

بداية، يجب أن نثير إلى أن فكرة استقلال الضمان الأصلي عن الضمان المقابل

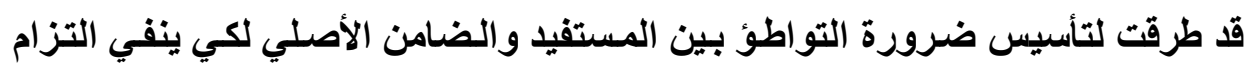

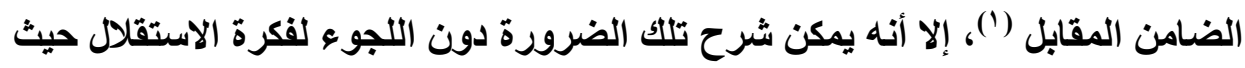

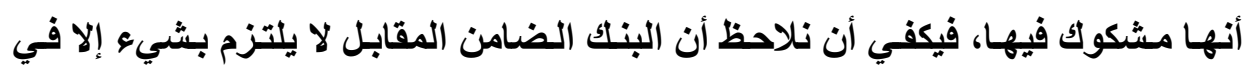

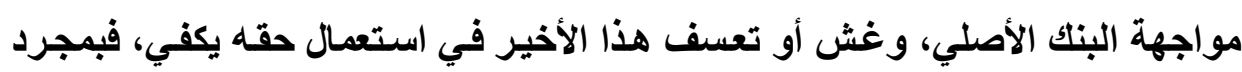

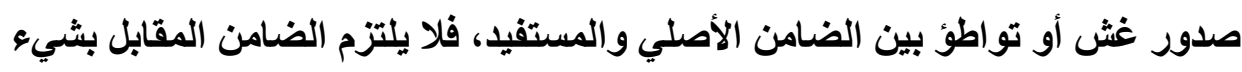

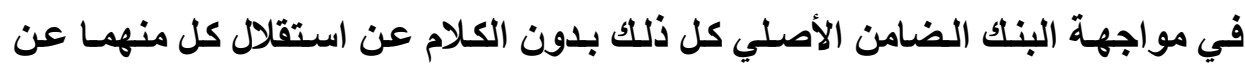
الآخر.

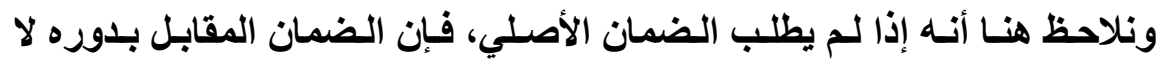

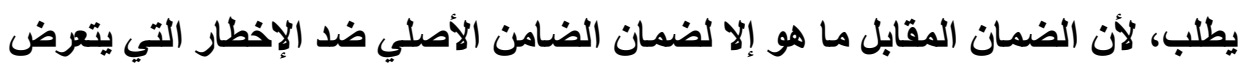

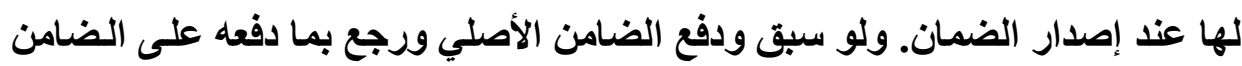

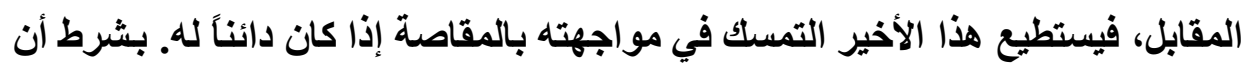
يكون الضامن الأصلي مديناً للضامن المقابل وليس للعميل الآمر. وأمام كل ذلك يصعب علينا أن نتكلم عن استقلال كل منهما عن الآخر.

(1) S. V. Stouffet, art, Prec. P. 1278; - Cass. Com. "decembre 1985, J. C. P. 1986 et (E) 11, 20593; Dalloz 1986. 213. note VASSEUR. 


\section{الفرع الثانتي \\ الاستثناءات على هبدأ استقلال التزام البنك}

\section{عن عقد الأساس}

هل الاستقلال الأي يتمتع به خطاب الضمان عن العقد الأصلي هو استقلال مطلق، أم ترد عليه بعض القيود؟ بمعنى أخر، هل مطالبة المستفيد للبنك الضامن بدفع قيمـة

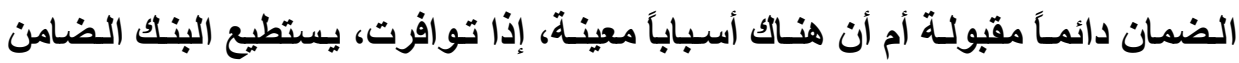

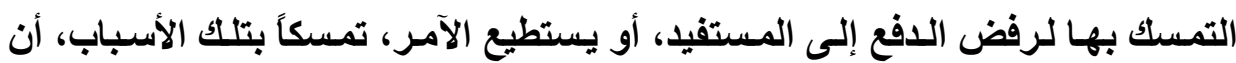
يطلب من البنك الضامن الامتناع عن الدفع إلى المستفيد؟ قبل الإجابة على هذا السؤال يجب أن نوضـح أن مبدأ الاستقلال السابق شرحه مقرر بالدرجة الأولى لمصلحة المستفيد، الذي يستطيع بمجرد طلبه من البنك أن يحصل

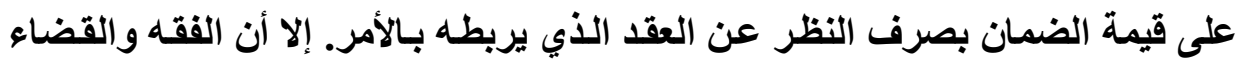
قروا أن إطلاق مبدأ الاستقلال فيه نـوع من الإجحاف بـالأمر، وخصوصاً في الحالات

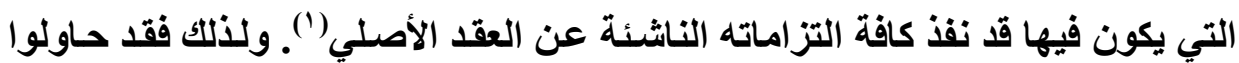
تقريـر بعض القيـود على الاسـتقلال للموازنـة بـين مـصالح الطرفين، العميـل الآمـر، والمستفيد. ولكن لما كان هذا الاستقلال هو الذي يدفع عادة المستفيد لقبول هذا النوع من الضمان المصرفي، فقد تثدد القضاء في الثروط الواجب توافرها في القيود التي

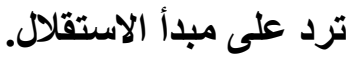

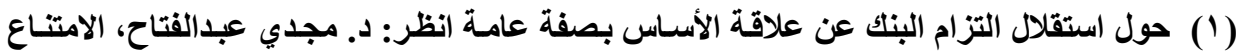

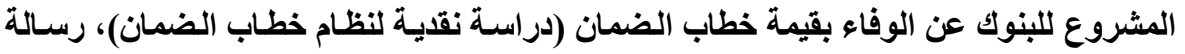

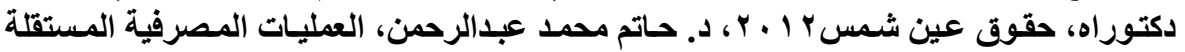

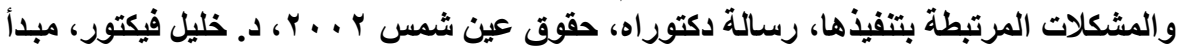

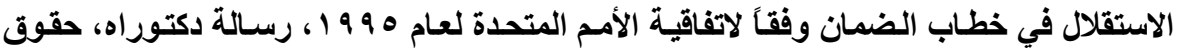




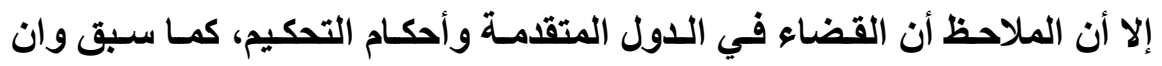

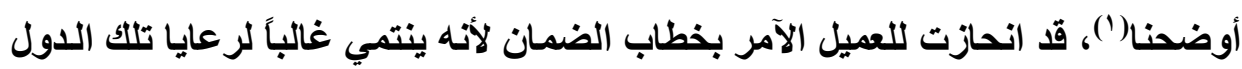

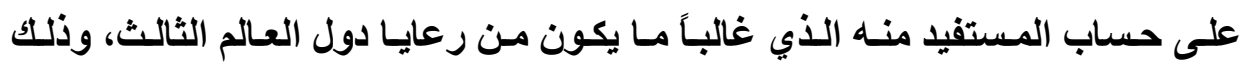
بالتوسع في الاستثناءات على مبدأ استقلال التزام البنك عن علاقة الأسـاس، إذ أن تلكت الاستثناءات تصب في صـالح العميل الآمر بالخطـاب لأن من شـأنها الربط بين التزام البنك وعلاقة الأسساس ممـا يمكن هذا العميل من التمسك بالدفوع الناشئة عن علاقة الأساس لمنع البنك من دفع قيمة الخطاب، وهذا الوضع يحقق حمايـة للعميل المذكور

$$
\text { على حساب المستفيد(") }
$$

ويمكن، استخلاصاً من الأحكام التي صدرت في الدول المتقدمة، وخصوصاً في

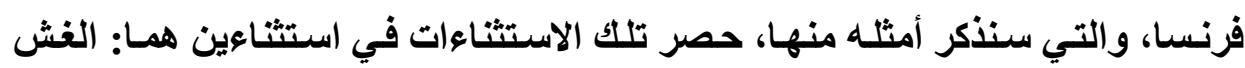

الصادر من المستقيا (أولاً)، وتعسفه الظاهر (ثانياً).

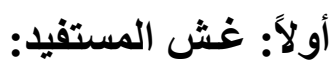

اختّت الآراء حول تعريف غش المستفيا ( ) وإثباته (Y).

$$
\text { 1 ـ تعريف غش المستفيد: }
$$

يتعين بداية أن نشير إلى أن الغش في مجال خطاب الضمان يختلف عن الغش في

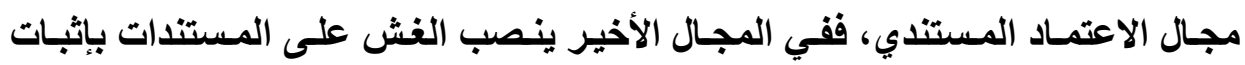

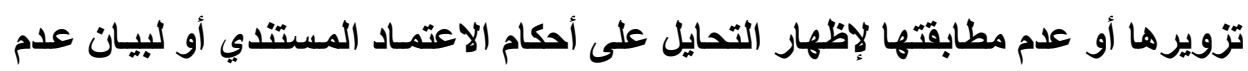
مطابقة البضاعة محل عقد الأسساس الثابتة في تلك المستتدات للبضاعة التي وصلت بالفعل. وإثبات الفش في الاعتمـاد المستثندي صعب لتعلقه بالمستثدات فقط ولصعوبة

(1) (نظر ما سبق، ص س ا ا وما بعدها.

(2) Stoufflet, la garantie bancaire à premiere demande, clunet 1987, p.265. 
إثبات تزوير هذه المستندات خصوصاً عندما يكون التزوير متقناً، فضلًا عن الربط بين المستتدات والبضاعة وهذا يتنافى مع جوهر وفلسفة الاعتماد المستندي. أما إثبات الغش في مجال خطاب الضمان فهو أكثر سـهولة، لاتسـاع دائرة حالاتـه

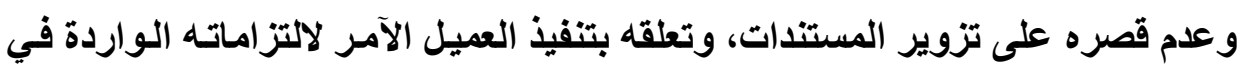
علاقة الأساس، وذلك بإثبات غياب كل حق للعميل الآمر تجاه المستفيد. ولكن ما المقصود بالغش في هذا المجال؟ أن غالبية الفقهاء قد عرفوا الغش، بأنه التأكد من عدم وجود أي حق للمستفيد

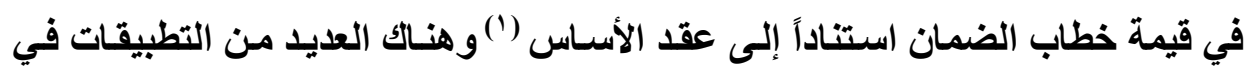
القضاء الفرنسي التي اعترف فيها بوجود غش من جاتب المستفيد، نـكر منها على

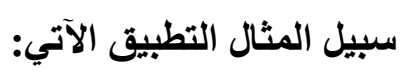
أبرمت شركة فرنسية تدعى . S. A. Eقدان مع بنك إيراني لإنشاء الملايين من

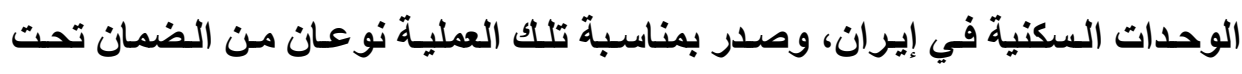

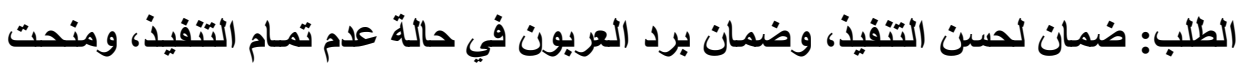
تلكك الضمانات من بنك إيراني في بلد المستفيد كضامن أصلي، مـع تعيبين بنك فرنسي كضامن مقابل.

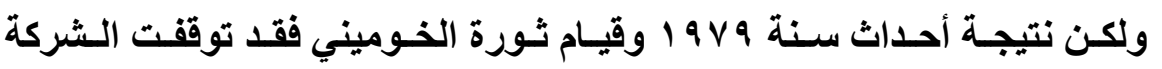
الفرنسية S. A. E. عن العمل ولم تكمل المشروع المتعاقد عليه، وطلبت من قاضي الأمور المستعجلة، ومن قاضسي الموضوع منـع البنتك الفرنسي بصفته ضـامن مقابل،

(1) Cour d'appel de Pairs 14eme ch. 12 Juin 1985 Banque 1986, 190 ob. Rive - Lange. 
والبنك الإيراني باعتباره ضامن أصلي من دفع قيمة الضمان، وإلزام البنك الذي تعاقدت معه بدفع قيمة الجزء الذي ثم تنفيذه في العملية، علاوة على استرداد خطاب الضمان. فقدر قاضـي الأمور المستعجلة أن طلب الدفع لو قدم من جانب البنك الإيرانسي المستفيد من خطاب الضمان، فإنـه سيكون منطويـاً على غش، وأصدر قراراً للبنكيين (الضامن الأصلي والضامن المقابل) بالامتناع عن الدفع لحين الفصل في الموضوع.

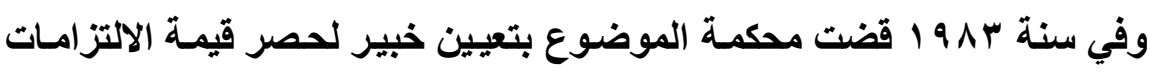
التي تقع على كل من الشركة الفرنسية .S. A. E والبنك الإيراني، الطرف الآخر في

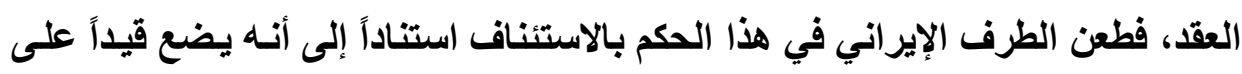
استقلال التزام البنك الضامن بدفع قيمة الضمان، الذي يجب أن ينفذ بمجرد الطلب، ورفعت الثركة الفرنسية استئنافاً فرعياً مطالبة بمنع البنكين من الدفع.

فقضي الاستئناف بحق الثركة الفرنسية في منع البنكين من الدفع، وأسس هذا

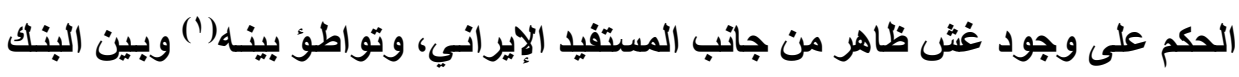
المحلي الإيراني الضامن الأصلي، وقد أثبتت المحكمة ذلك على مرحلتين: فى المرحلة الأولحى: بدأت المحكمة بإثبات أن طلب دفع الضمانات المقدم من البنك الإيراني الطرف في العقد إلى البنك الإيرانسي الضامن الأصلي كاتت تنطوي على غش حيث أن السلطات الإيرانية قد أنشأت شركة تسمى "إيران .S. A. E. وعين جميع أعضاء مجلس الإيس

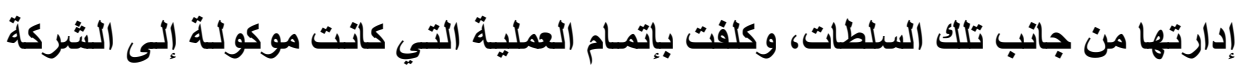
الفرنسية .S. A. E، وصقَت السلطات الإيرانية تلك الثركة دون إعطائها أي نوع من الته

(1) Cour d'appel de Paris 14eme ch. 12 Juin 1985 banque 1986, 190 ob Rive - Lange. 
التعويضات، ولا رد أي ممتلكات لها على الأراضي الإيرانيـة، فلم يكن الطرف الإيراني

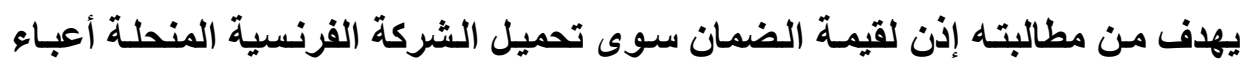

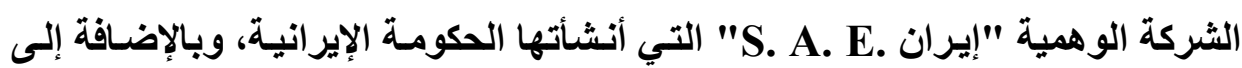
ذلك فبإن الإجراءات التي اتخذتها السلطات الإيرانية ضد الشركة الفرنسية قد جعلت تنفيذ هذه الشركة لالتزاماتها مستحيلاً.

\section{وفى المرحلة الثانية:}

فقد لاحظت المحكمة أن موقف البنك الإيراني (الضامن الأصلي) والذي أعلن أنهـ دفع للبنك الإيراني المستفيد والطرف الآخر في الصفقة، والذي كان تحت رقابة الدولة الدانة الإيرانية، وعلى علم كامل بتطورات العلاقة بين الثركة الفرنسية والمتعاقد الإيراني، لا يرقى الثك إلى الغش والتواطؤ الأي ينطوي عليه. لقد استخلصت المحكمة من ذلك، أنه أخذا في الاعتبار هذا التواطؤ والغش من جاتب البنك الإيراني الضامن الأصلي، فإنه لا يستطيع الرجوع بما دفع للطرف الإيراني، على البنك الفرنسي الضامن المقابل ولا على الثركة الفرنسية الآمرة (S. A. E.

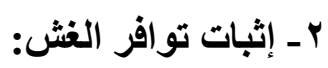

إذا كان تحديد حالات الغش في مجال الاعتماد المستتدي أمراً سهلاً نسبياً لارتباط

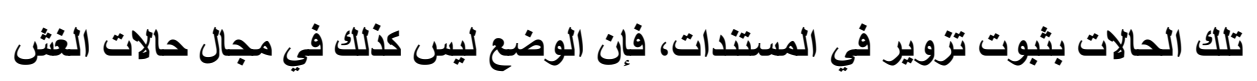
في خطاب الضمان، لتشعب هذه الحالات وتعددها وارتباطها بأكثر من مسألة واقعية. إلا أن وسـيلة ثبـوت تـوافر إحـى حـالات الغش فـي الحسالتين واحـدة، لأن هـذه الحالات تستتد في خطاب الضمان والاعتمـاد المستتدي على معيـار واحد وهو ثبوت غياب كل حق للمستقيد في مواجهة العميل الآمر. 
ووسيلة ثبوت غيسب هذا الحق هو صدور حكم من القضاء المستعجل يوقف

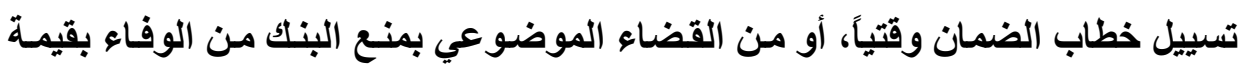
الخطاب. ولا تكفي أية وسيلة أخرى للتدليل على توافر الغش نتيجة غياب حق المستفيد

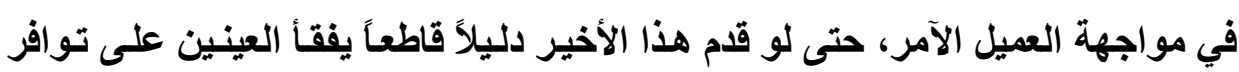

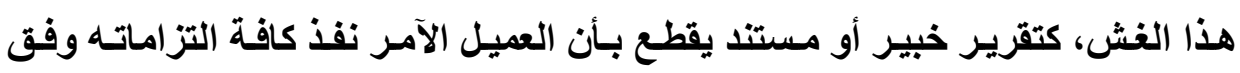

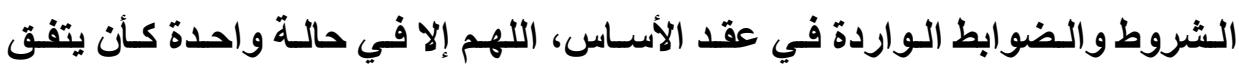

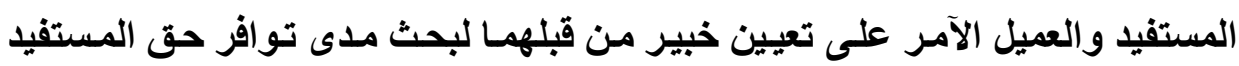

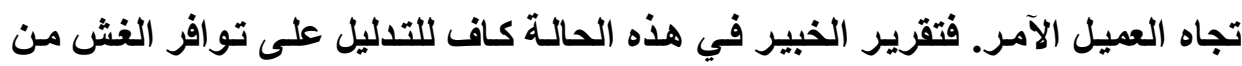
عدمه. وهذا الوضع لا ينطوي على أي مساس بالحمايـة التي يتمتع بها المستفيد في

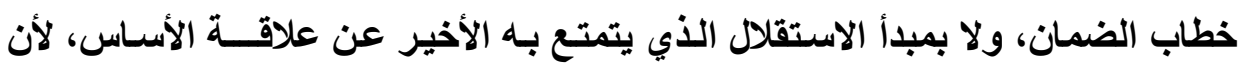

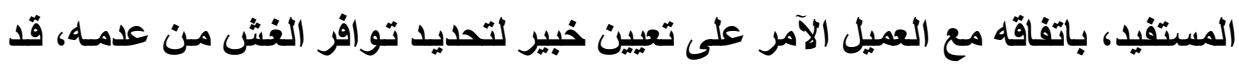
تنازل عن التمسك بمبدأ استقلال خطاب الضمان عن علاقة الأسـاس، فهذا المبدأ مقرر أصلاً لمصلحته.

وعودة إلى وسيلة الإثبات الوحيدة في ثبوت الغش من عدمه، وهي حكم القضاء

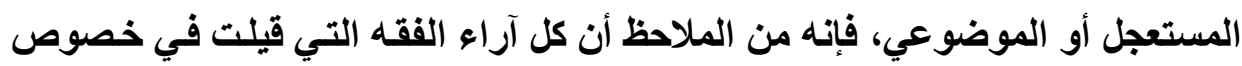
الغش أو أحكام القضاء التي صدرت بشأنه، قد أجمعت على تلك الوسيلة، ولكن الخلاف بينها كان يدور حول شروط الدليل المقدم للمحكمة وقوته لإقناعها أن تصدر حكماً وقتياً

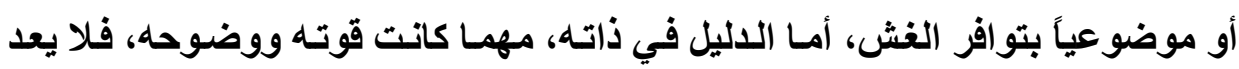

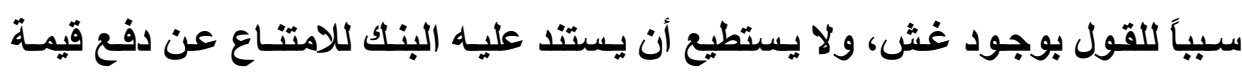
خطاب الضمان. وهذا القول يتفق في الحقيقة مـع الخصائص المميزة لالتزام البنـك في خطاب الضمان، والتي من أهمها مبدأ استقلال هذا الالتزام عن علاقة الأسـاس. فالوسيلة 
الوحيدة للقضاء على هذا المبدأ ومحوه هو صدور حكم قضائي بتوافر الغش في

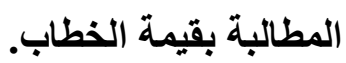

ولكن بقى في هذا الخصوص مسألتين يتعين التعرض لهمـا وإيضاحهما، وهمـا: هل يشترط أن يكون الفش صادراً من المستفيد؟. وهل المطالبة بقيمـة خطاب الضمان

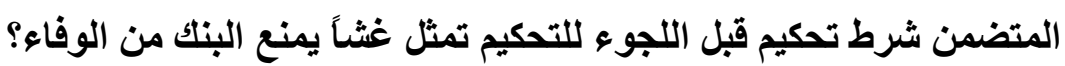

أما من مسألة ضرورة صدور الغش من المستفيد للاحتجاج بـه ضده، فهي محل للخلاف، فذهب رأي (') إلى أنسه يجب أن يصدر الغش من المستفيد وليس من الغير.

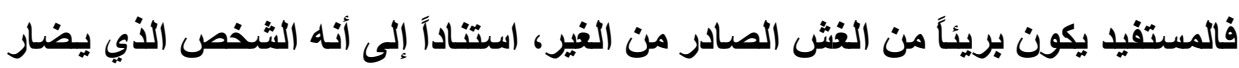

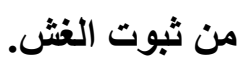

وذهب رأي آخر(") إلى أنه لا يشترط أن يصدر الغش من المستفيد نفسه، و إنمسا

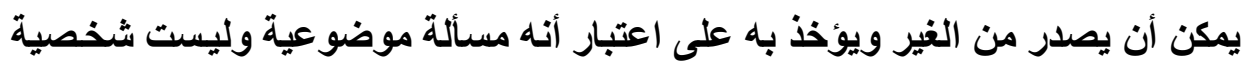

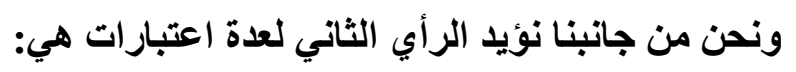
ـ أن مبدأ أن "الغش يفسد كل شيء" هو مبدأ عام موضوعي يرتبط بالغش ذاتـه

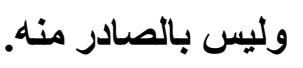

ــ أن العبرة بواقعة توافر الغش في ذاته بصرف النظر عن مرتكبه. فالمعيار هنـا موضوعي وليس شخصي.

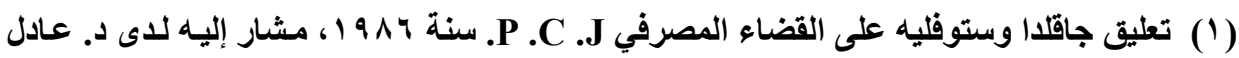

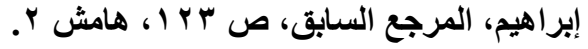

(2) Cass. Com. 29 avr. 1986. D, 1987, P. 17, 20 note VASSEUR; -Cass. Com. 10 Juin 1986, Rev. Banque 1985, p. 92; - Andre PRUM, application de l'adage "fraus ommia corrumpit" à propos des garanties à première demande, reflexions sur l'arrêt de la cour de cassation française du 10 Juin 1986; D. P. C. I 1987, t. 13. 
- أن عدم اشتراط صدور الفش من المستفيد ينطوي على توسع محمود في مجال

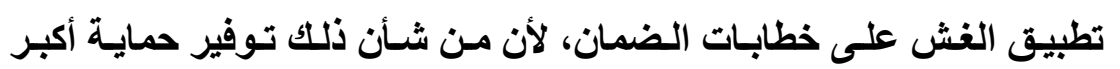

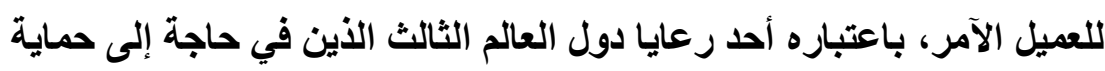

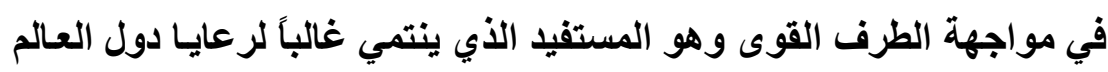
المتقام.

وفيما يتعلق بمدى اعتبار مطالبة المستفيد لقيمة الخطاب قبل اللجوء إلى التحكيم

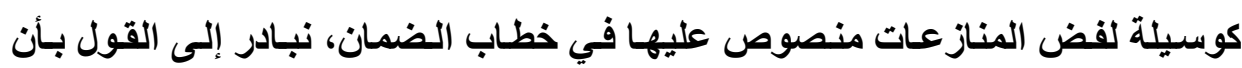

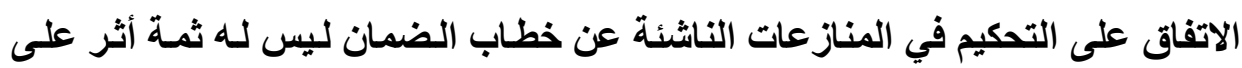

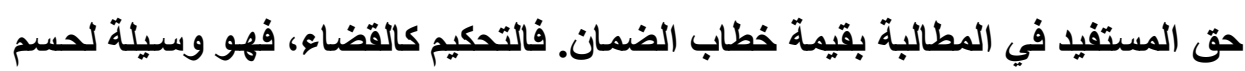

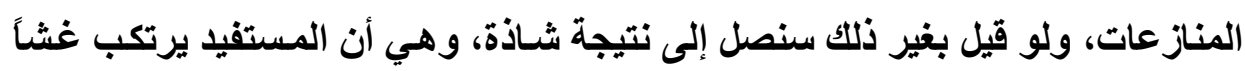

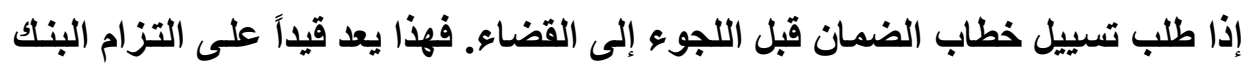

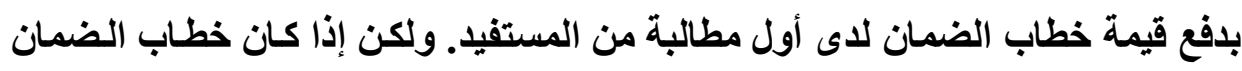

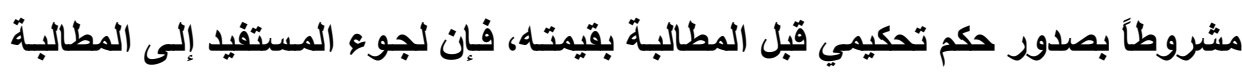

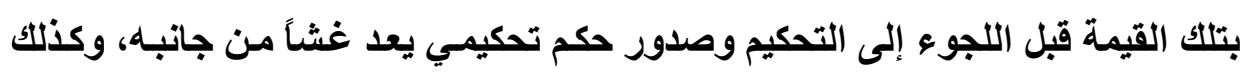
الأمر لو اتفق على التحكيم بعد نشوء النزاع المتعلق بتسييل خطاب الضمان (') ثانياً: التعسف الظاهر من المستفيد: القيد الثاني الذي حاول القضاء تقريره على مبلأ استقلال التزام البنك الوارد في خطاب الضمان فيتمثل في التعفف الظاهر .Abus manifest من جانب المستفيد.

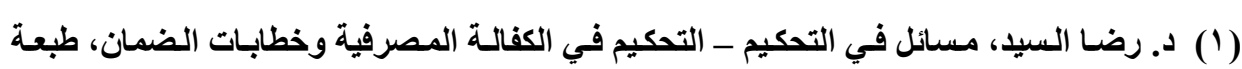

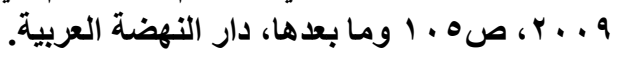


ولكن يثـور السؤال بـداءة حسل مــا إذا كانتـا فكرتـي الغش والتعسف الظـاهر مختلفتان عن بعضهما أم أنهما مترادفان بكون

أنهما فكرتان مختلفتان عن بعضهما (') وأن كانتا تؤديان إلى نفس الغرض وهو

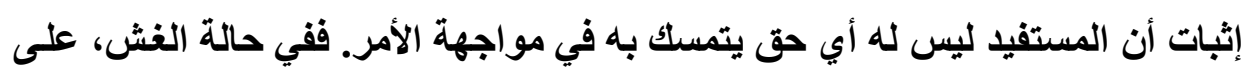

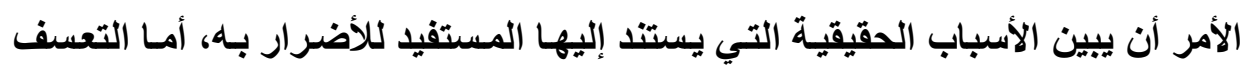

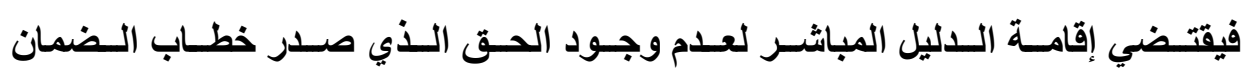
لتنفيذه (1 مكرر).

ولبيـان متى يمكن القول بوجود تعسف ظاهر Abus manifiste من جانب

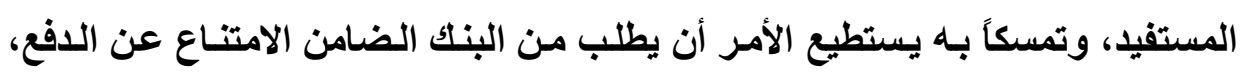
نذكر التطبيق الآتي في القضاء الفرنسي.

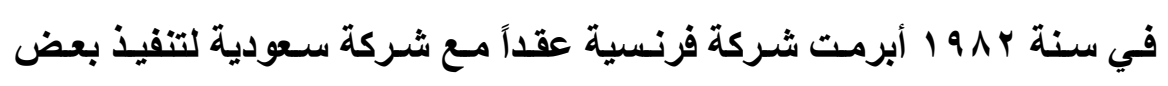
الأشغال، وطلبت من بنك فرنسا للتجارة الخارجية منح الثركة السعودية، ضمان تحت فئس

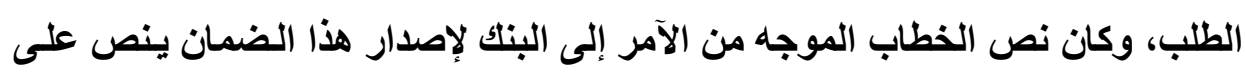

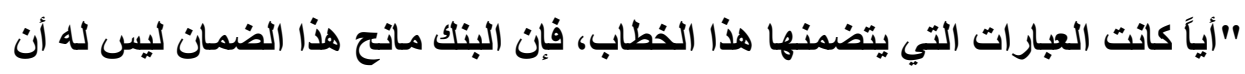

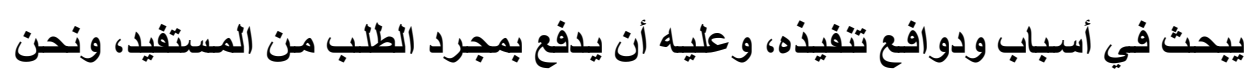

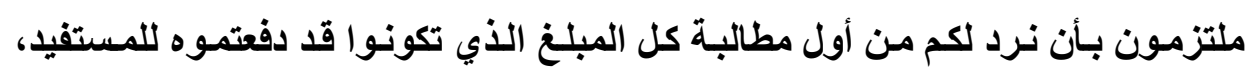

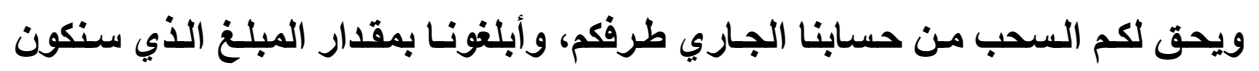

(1) Cour d'appel 14eme ch.12 Juin 1985, Banque 1986, 190 obs. Rive Lange; - Cass. Com. 21 mai 1985, Banque 1986. p. 87; - Cass.=

(1bis) Com. 120 Janvier 1987, J. C. P. Ed. (E) 1987, 11. 14882. ob. J. Stoufflet. 
مدينين لكم به، ونحن نتنازل مقدماً وبدون تحفظ عن الاعتراض على شرعية هذا الدفع الأي يتم تنفيذاً لالتزاماتنا".

وقد قام بنك فرنسـا للتجـارة الخارجية بتكليف أحد البنوك السعودية بـأن يعطي

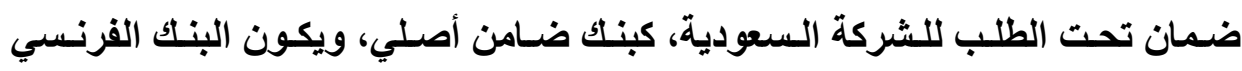

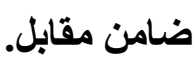

وكـان مقرراً انتهاء مـدة الضمان الأصلي والضمان المقابل في ^ا مـايو سـنة

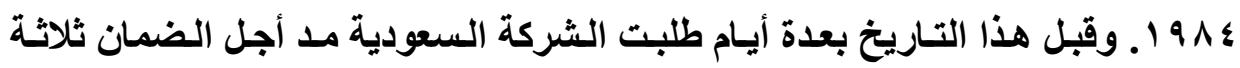
أشهر أخرى احتجاجاً بأن الثركة الفرنسية قد أخلت بتنفيذ التزاماتها التعاقديـة، مهددة أما المد أو الدفع الفوري، ولكن الشركة الفرنسية وافقت على المد شهر واحد فقط لكي

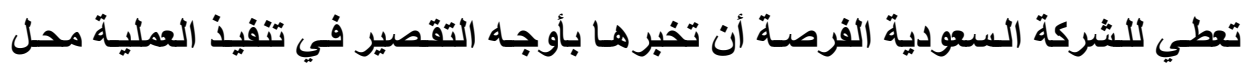

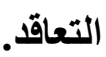

ولكن الشركة السعودية تقدمت إلى البنـلك الضامن تطلب دفع قيمـة الضمان،

وطلبت الشركة الفرنسية من قاضي الأمور المستعجلة منع البنك من الوفاع استناداً إلى أن طلب الثركة السعودية ينطوي على تعسف ظاهر، حيث كان كل الهدف هو الحصول على مد لمدة ثلاثة أثـهر، وأجـاب قاضسي الأمسور المستعجلة طلب الشركة الفرنسية، ومع ذلك قام البنك الضامن (الفرنسي) باستئناف هذا الحكم لأنه يريد أن يفي بالتزاماتها التي تعهد بها في مواجهة المستفيد، وتمسكت الشركة الفرنسية في الاستئناف بـأن جميع اشتراطات الجانب السعودي قد تحققت، وذلك بناء على إقرار صادر من ممثله. ورفضت محكمة الاستئناف الأمر الصادر من قاضسي الأمور المستعجلة استناداً إلى أن استقلال الضمان تحت الطلب عن عقد الأساس لا يمنع البتك من الدفع، وأضافت التهن قائلة "أنـه لا يمكن للشركة الفرنسية أن تحتج بأنها نفذت كل التزاماتها الواردة في لاني 
العقد الأصلي حتى تعفي البنك الضامن من الدفع، لأن التزام هذا البنك قد نشأ عن اتفاق

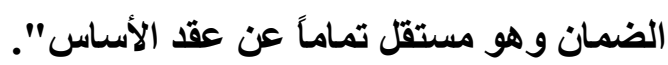

وطعن في هذا الحكم بالنقض، ولكن محكمة النقض قد أيلت حكم الاستئناف على

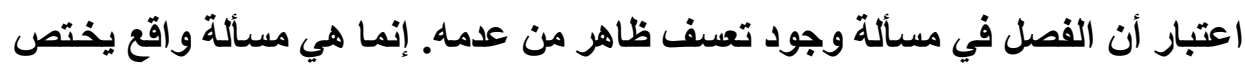

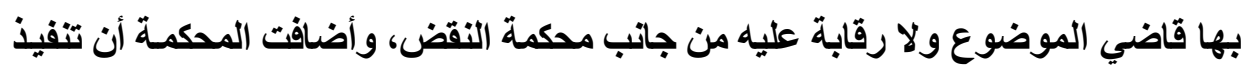
كافة شروط العقد الأصلي لا يعفي الضامن في التزامه بالدفع إلى المستفيد (') ومن ذلك يتضح أن الثركة الفرنسية لم تسنطع إقامـة اللاليل القـاطع على وجود تعسف ظاهر من جاتب الثركة السعودية، ولو كاتت قد نجحت في إثبات ذلك لكان لـه أثره على استقلال خطاب الضمان عن علاقة الأسـاس، فلو كاتـ الشركة الفرنسية قد فئ قدمت مثلاً محضر جرد موقع من الطرفين بكل مضمون العملية، لكان في استطاعتها حينئذ إثبات التعسف. ويلاحظ أنه من الوسائل التي أقرتها أحكام التحكيم، ويستطيع من خلالها الآمر إثبات وجود تعسف ظاهر نذكر من ذلك على سبيل المثال: لو كان الضمان لحسن التنفيذ، وكان سبب طلب الدفع الصادر من المستفيد هو عدم تسليم البضائع محل التعاقد، وقدم الأمر إلى القاضي المختص شـهـادة من الجمـارك تفيد تمام التسليم أو صدر حكم قضائي أو حكم تحكيم يفيد بأن التسليم قد تم فهنـا نكون

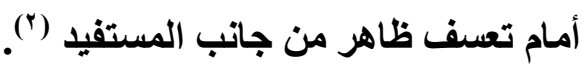

(1) Cass. Com. 21 Mai 1985, Banque 1986. 87 note Rive - Lange; Dalloz 1986, J. 214 obs. VASSEUR.

(2) Cour d'appel de Riom, 14 Mai 1980, Dallez 1981, 36 obs. VASSEUR. 
وكذلك الأمر لو ورد حسن التتفيذ في تقرير خبير تم تعيينه بموافقة الطرفين.

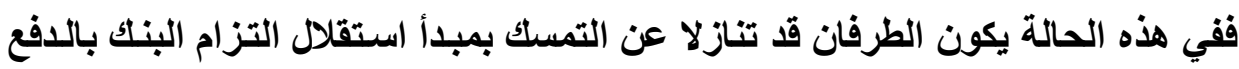

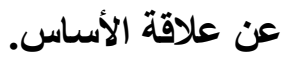

وفي جميع الأحوال يجب أن يلاحظ أنه لا يوجد في التشريع المصري مفهوم

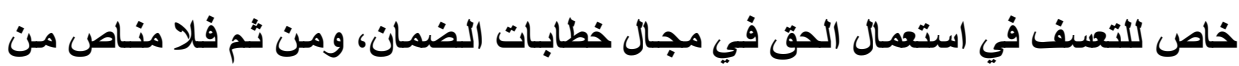

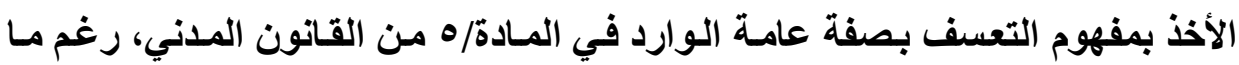

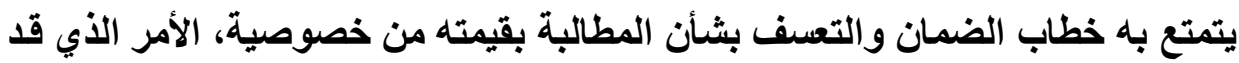
لا يكفي معه مفهوم التعفف في القواعد العامة لبيان وتفسير حالات التعسف في مجال

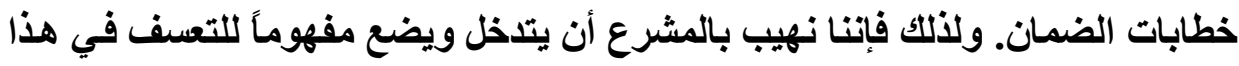
المجال، بل وفي مجالات العلاقات التجارية عموماً (')

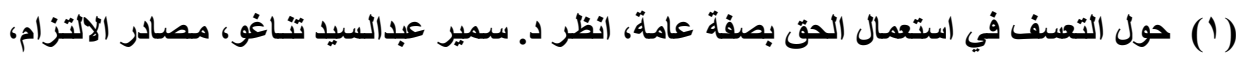

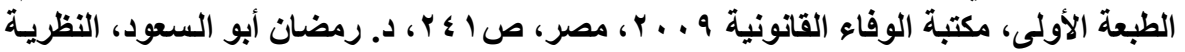

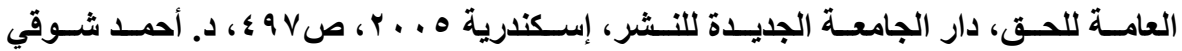

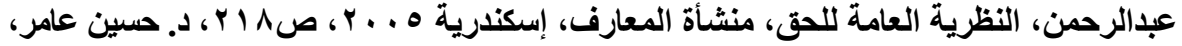

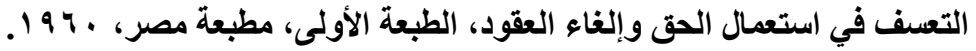


تناولنا على مدار هذا البحث موضوع الاستقلال بين العلاقات التجاريـة المرتبطة. وقد حاولنا الإجابة على التساؤلات التي يطرحها هذا الموضوع، وتعرضنا للصعوبات والمشاكل القانونية التي يثيرهـا محساولين وضـع حلول لهـا مـن خلال تحليل العلاقـات الناشئة في مجال العقود التجارية المرتبطة، وذلك ببيـان مضمون ومحتوى كل علاقة منها ومدى استقلالها وارتباطها بالعلاقات الأخرى، والتأثير المتبادل بينها، واستخلصنا

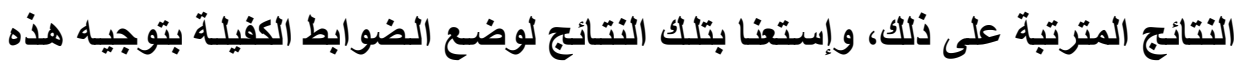
العلاقات نحو تحقيق الهرف النهائي منها، وذلكك بجعل هذه العلاقات متكاملة وليست متعارضة أو متنافرة، وبجعل التأثير بينها إيجابياً وليس سلبياً. إلا أن تلـك المحساولات المبذولـة لاز زالـت فـي حاجـة لمسساندة المسشرع بوضـع نصوص واضحة وصريحة ومفصلة تكون كفيلة بإزالة الغموض واللبس الذي يلف تلك لك العلاقات المرتبطة وصولاً لحلول ملائمة للصعوبات والمشاكل القانونية التي تثيرهـا. كمـا أن هذه المحاولات في حاجـة أيضـاً لجهـ مبذول مـن القضاء لتفسير النصوص الغامضة في ضـوء واقعـات النزاع المعروضـة عليه ليستخلص منهـا النتـائج ويضع المبادئ القانونية التي قد تكون هادياً ونبراسـاً للمشرع عند وضعاه لنصوص تعالج المشاكل التي تنتج عن العلاقات التجارية المرتبطة ذات الصلة. ففي مجال اتفاق التحكيم في المنازعات الناشئة عن العلاقـات التجاريـة المرتبطة رأينا أن هناك عدة مصطلحات في حاجة إلى ضبطوتحديد، مثل استقلال اتفاق التحكيم وانفصاله، ومده وانتقالهه. فالأمر في حاجة إلى إيضاح، متى يكون هذا الاتفـاق مستقلًا ومتى يكون منفصلاً، وبيـان أهمية التقرقة بين الاستقلال والانفصال، خصوصاً فيمسا يتعلق بمدى ارتباط مصير هذا الاتفـاق بمصير العقد الذي يتضمنه. فعندما يرد العقد الأصلي واتفـاق التحكيم في وثيقة واحدة، هي العقد الأصلـي متضمنا اتفـاق التحكيم 
ضمن بنوده، فهنـا يكون هذا الاتفـاق مستقلاً، ولا يتأثر بمصير العقد الأصلي إلا في حالتين هما: إذا كان محل هذا العقد مخالفاً للنظام العام، وإذا كان الرضا في إبرام العقد قد شابته أحد عيوب الإرادة، أو كاتت الأهلية ناقصة أو منعدمة، باعتبار أن الإرادة التي أبرمت العقد والاتفاق الوارد فيه هي إرادة واحدة. أما إذا ورد اتفـاق التحكيم في وثيقة

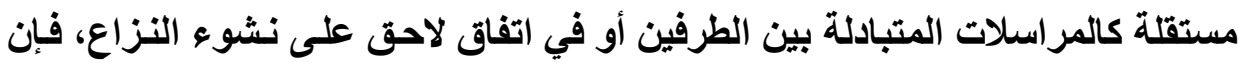
الاتفاق هنا يكون منفصلاً، ولا يتأثر ببطلان العقد الأصلي إذا كان هذا البطلان راجعاً

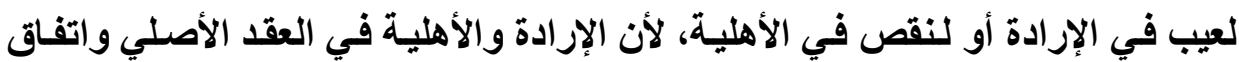
التحكيم ليست واحدة، فقد تكون الإرادة في العقد الأصلي معيبـة أو الأهلية ناقصة. ولكنها في إبرام اتفاق التحكيم تكون تلك الإرادة سليمة وهذه الأهلية كاملة. فهنـا يبطل العقد الأصلي ويظل اتفاق التحكيم صحيحًا. وكذلك قد يبرم العقد الأصلي بوكالة عامـة فيكون صحيحاً، وييرم اتفاق التحكيم بوكالة خاصة، فيكون هو الآخر صحيحاً. وإذا كان تطبيق القواعد العامة في خصوص استقلال اتفـاق التحكيم أو انفصاله كافياً، فإن الأمر ليس كذلك في شأن مد اتفاق التحكيم من علاقة إلى أخرى مرتبطتين، وسريان هذا الاتفاق على من لم يوقع عليه كتابة. فقد رأينا أن هذا المد يحدث، ويسري اتفاق التحكيم على غير الموقع عليه، إذا كان هذا الأخير قد أشترك في في إبرام العقد فئد الأصلي أو في تنفيذه أو في إنهائه، على اعتبـار أن اشتراكه في أي من تلك الأمسور

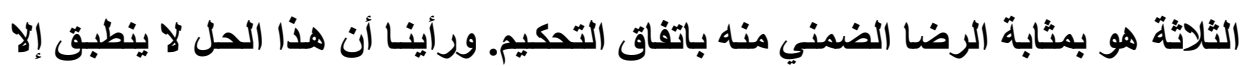
إذا كان القانون الذي يسري على إجراءات التحكيم يستلزم الكتابة لمجرد إثبات اتفـق التحكيم وليس انعقاده. وبالتالي فإنها لا يجوز الأخذ بهذا الحل في مصر ، إذا كان القانون

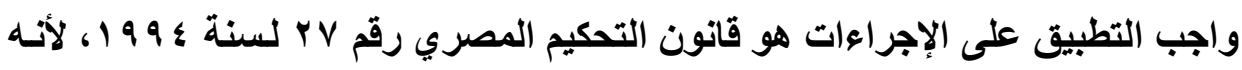
يشترط الكتابة لانعقاد اتفاق التحكيم وليس لمجرد إثباته. ولذلك فإنتا نهيب بالمشرع المصري أن يتدخل ويجري تعديلاً على دور الكتابـة في اتفاق التحكيم، خصوصاً إذا كان التحكيم يتعلق بمنازعات ناشئة عن عقود التجارة 
الدولية، بأن يستلزم الكتابة في اتفاق التحكيم في منازعات هذه العقود لمجرد الإثبات وليس للانعقداد، وذلك تحقيقاً للمرونـة في تطبيق اتفـاق التحكيم بمـا يزيــ من فائدتهـ وفاعليته. وقد ذهبت بعض التشريعات في هذا الخصوص إلى مدى بعيد حيث لم تشترط

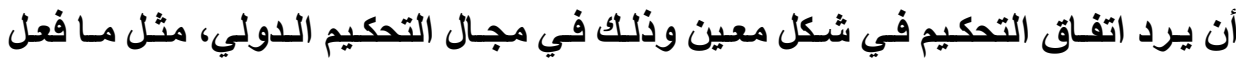
المشرع الفرنسي في المادة/ V • ه ا من قانون المرافعات الفرنسي المعدل بالقانون رقم

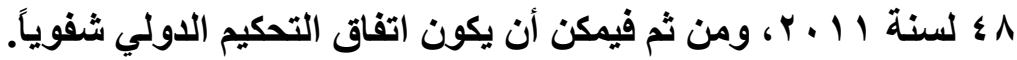
صحيح أن اشتراط الكتابة لانعقاد اتفاق التحكيم يعد ضمانة هامـة لمن يرغب في اللجوء للتحكيم، لأن اشتراط توقيعه كتابة على الاتفاق يجعله حريصاً عند هذا التوقيع لأنه يحرمه من حقه الاستوري في اللجوء إلى قاضيه الطبيعي. ولكن إذا تعلق الأمر بتحكيم دولي فإن الوضع مختلف، حيث أنه لا يوجد قاضي طبيعي، لأنه لا توجد محكمـة

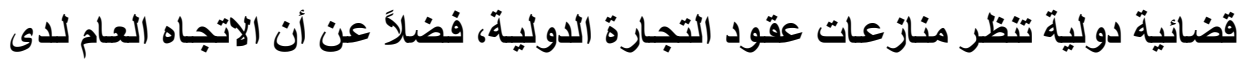
هيئات ومراكز التحكيم الدولية هو المرونـة في اتفاقات التحكيم لتحقيق فاعليتها بمد شرط التحكيم إلى كل من رضي به ضمناً. وفي مجال العلاقات الناشئة عن التعامل بالورقة التجاريـة رأينـا الخـلاف المحتدم

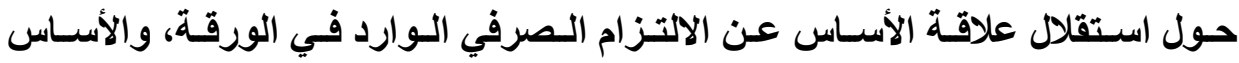

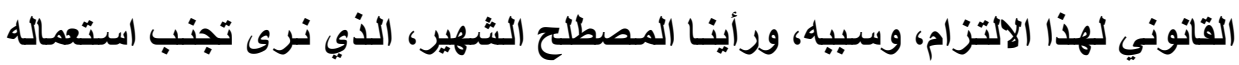
لعدم دقته وعدم وضوحه، وهو أن الالتزام في الورقة التجاريـة مجرد عن سببه، لأن هذا قد يعني أن هذا الالتزام ليس له سبب، فإذا قلنا بذلك فإنه سيكون التزاماً باطلاً، لأن

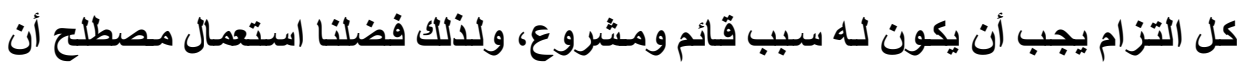
سبب الالتزام الصرفي مفترض في وجوده وفي مشروعيته. ولذلك فإنتا نهيب بالمشرع أن يعيد النص على بيان وصول القيمة كأحد البيانـات الإلزامية في الورقة التجارية، كما كان عليه الحال في تقتين التجارة الملغي. فالمشرع 
في قانون التجارة رقم VI لسنة 999 و 9 ، لم يعد يستلزم ذكر هذا البيان ضمن البيانـات

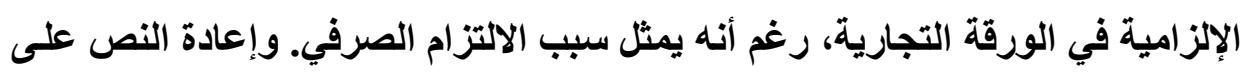

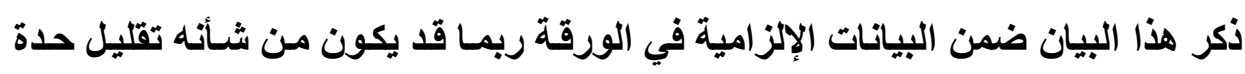
الخلاف حول البحث عن الأساس القانوني لهذا السبب الهيب.

أما العلاقات الناثئة عن الثركات التجارية، ومدى استقلال الأمة المالية للشركة

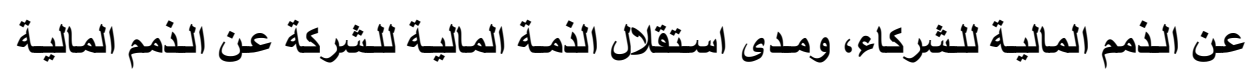

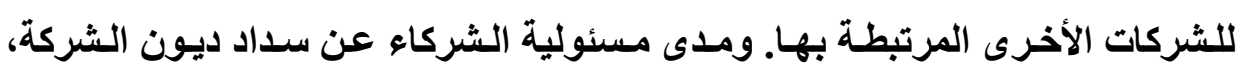

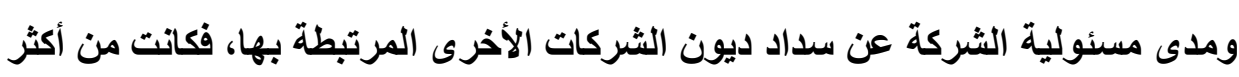
المسائل تشعباً وتعقيداً، نظراً للقصور التشريعي في هذا الشأن، خصوصاً في مجال

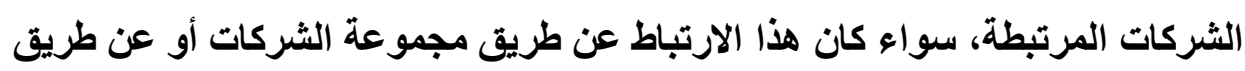

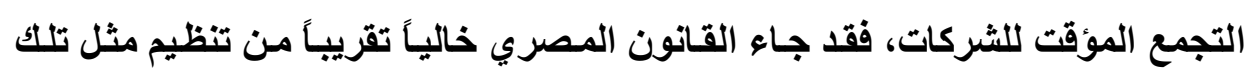

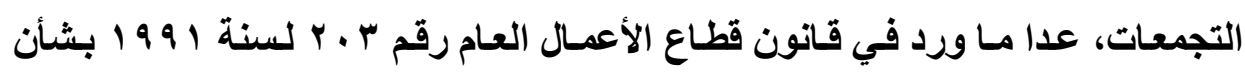
الشركات القابضة والشركات التابعة.

ونهيب بالمشرع أن يتذخل وينظم مجموعة الشركات والتجمع المؤقت للشركات

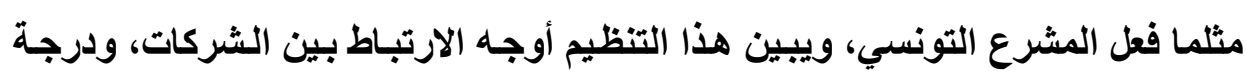
الارتباط التي تجعل إحدى الثركات المرتبطة مسئولة عن سداد ديون الثركات الأخرى.

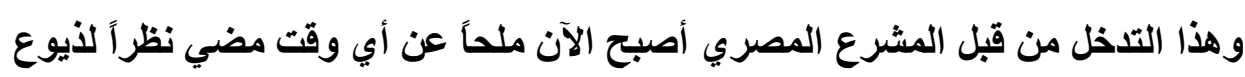

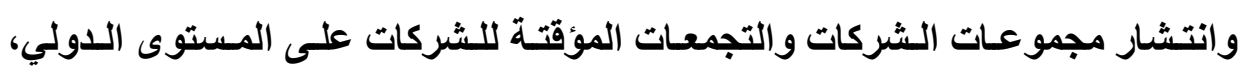
واضطلاعها بتنفيذ المشروعات الاقتصادية العملاقة، خصوصاً ذات البعد القومي منها

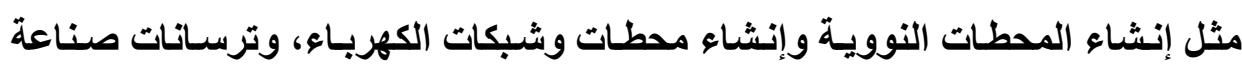
الأسـلحة والطسائرات وغيرهـا. ولا شك أن تتظيم المسئولية الناتجـة عن مشاركة عدة

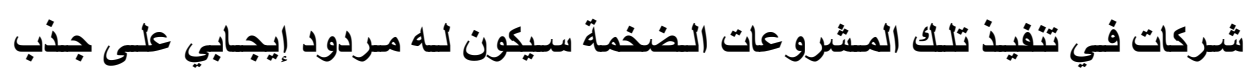
الاستثمارات الأجنبية. 
أمـا بالنسبة للعلاقـات الناشـئة عـن التعامـل بالاعتمـادات المستتندية وخطابـات

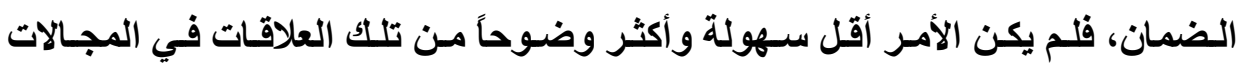

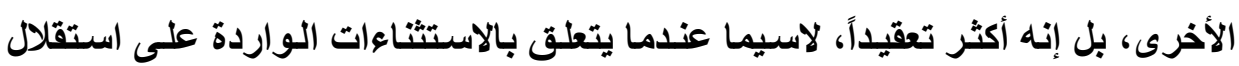

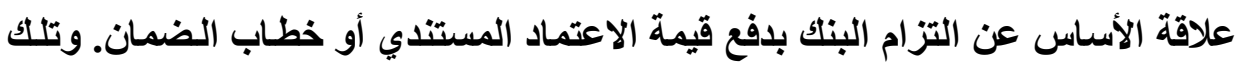

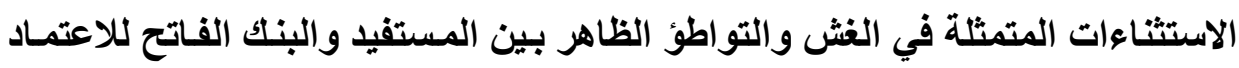

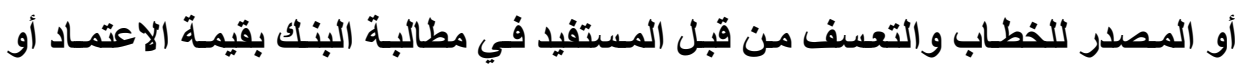

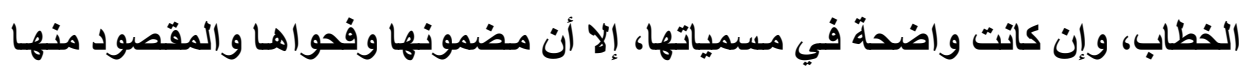

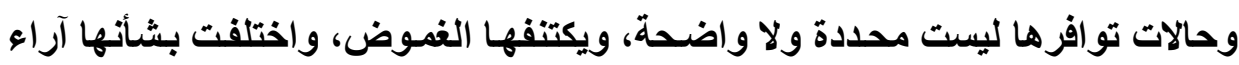

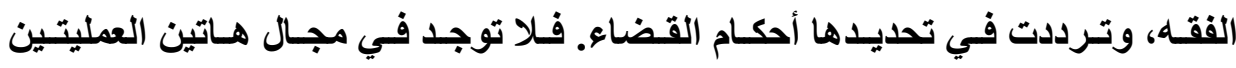

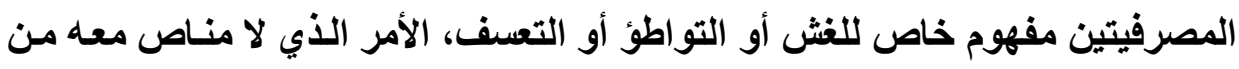

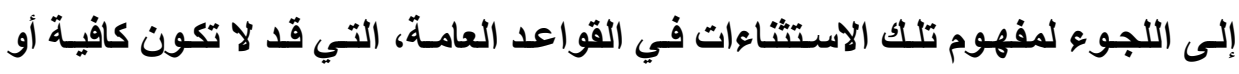

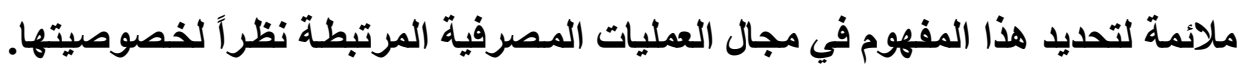

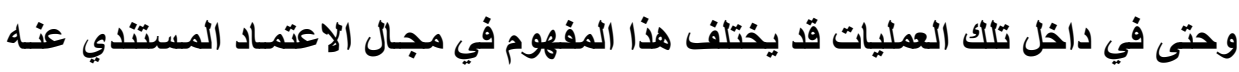

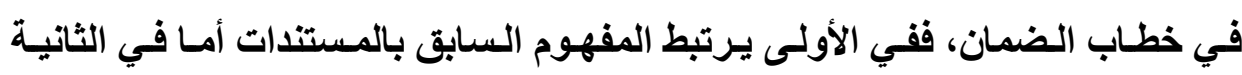
فيرتبط هذا المفهوم بالعديد من المسائل المتعلقة بخطاب الضمان.

ولا شك أن تحديد مفهوم الغش أو التواطؤ أو التعفف تثريعياً في مجال العمليات

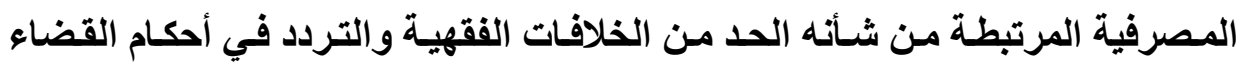

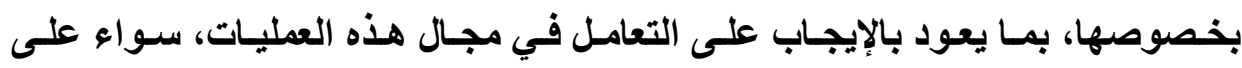
المستوى المحلي أو الدولي.

ومسن نافلـة القـول أن التظظيم التشريعي لمسـألة اسـتقلال العلاقِـات التجاريـة المرتبطة لن تكون بموجب نصوص نمونجيـة موحدة بالنسبة لجميع تلك العلاقات أياً

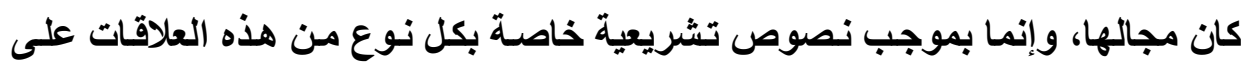
حدة نظراً لاختلاف طبيعتها وموضوعاتها.

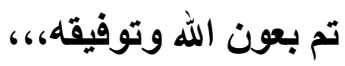




\section{المراجــــــ

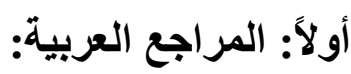 \\ 1 - دـ. أبو زيد رضوان: \\ - الأسس العامة في التحكيم التجاري الدولي، 1919 1، دار الفكر العربي. \\ ـ الثركات التجارية في القانون المصري المقارن، طبعة9 19 1 ، دار الفكر العربي. \\ ـ الأوراق التجارية، 99 9 1، شركة طابا للطباعة.

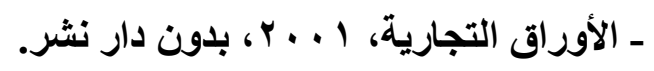

r ـ د. أحمد أبو الوفاع، نظرية الأحكام في قانون المرافعات، منشأة المعارف، إسكندرية . r...

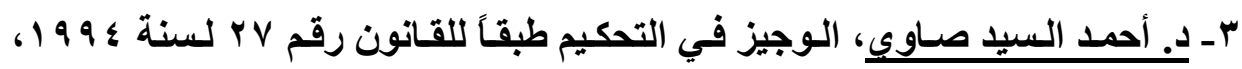

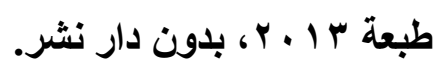

ع ـ د. أحمد حسان حافظ مطاوع: التحكيم في العقود الدولية للإنشاعات، طبعة V . . Y. دار النهضة العربية.

هـ د. أحمـ شـوقى عبدالرحمن، النظريـة العامـة للحق، منشأة المعـارف، إسـكندرية . r...

7- دـ أحمـد بركـات مـصطفى: العقـود التجاريـة وعمليـات البنـوك، دراسـة في قـانون

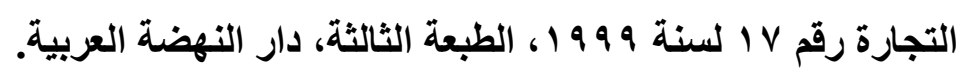

V- أسامة مساعدة، مدى مسئولية الشركة القابضة عن أعمال الشركة التابعة منشور dictaconsulting.com./coporateveil على الموقع الاكتروني 
^ـ دـ أكرم إبراهيم حمدان الزغبي، مسئولية المصرف المصدر في الاعتماد المستندي،

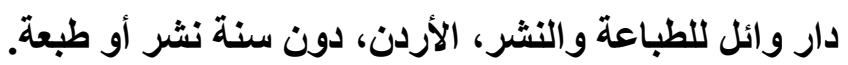

9 - د. أمين محمد بدر، الأوراق التجارية في التشريع المصري، تأصيل وتحليل لقواعد

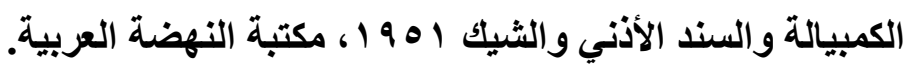

• 1 ـ دـ انطوان الناشفف، خليل الهندي: العمليـات المصرفية والسوق المالية، الجزء

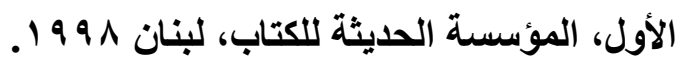

1 ا ـ دـ ثروت عبدالرحيد: شرح القانون التجاري المصري. الأوراق التجاريـة، الطبعة الأولى، نادي القضاة.

r ا ـ دـ جمـال السيد عبدالحميد، الورقة التجاريـة كضمان للائتمـان المصرفي، رسـالة

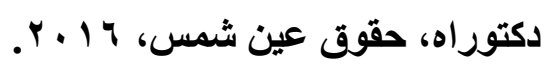

با ـ ــ. جمال محمود عبدالعزيز، الالتزام بالمطابقة في عقد البيع الدولي للبضائع وفقاً

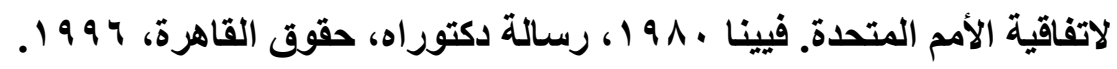

ع أ - دـ حاتم رضا السيد:

ـ اتفاق التحكيم في منازعات الشركات، رسالة دكتور اه حقوق القاهرة، ب ا ـ ؟. ه 1 - د. حاتم محمد عبدالرحمن:

ـ العمليـات المـصرفية المستقلة والمـشكلات المرتبطة بهـا ب . . r ، دار النهضة

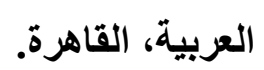

19

ـ الأهلية الناقصة والمؤقتة للشركة ه 1 ـ ب ، دار النهضة العربية. ـ التحكيم المبتور، هيئة واتفاقًا 17 ـ ب ، دار النهضة العربية. 
- وحدة الإفلاس وتعدد التفليسات ؛ ا ـ r، دار النهضة العربية.

ـ مسئولية المستحوذ على شركة المساهمة غير المفلسة والمفلسة، طبعة ج1 1 ـr،

$$
\text { دار النهضة العربية. }
$$

V - د. حسام عبدالغنى الصغير، الاندماج القانوني للشركات، رسالة دكتوراه حقوق

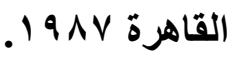

$$
\text { 1 ا - د. حسام محمد عيسى: }
$$

ـ الثركات التجارية، النظريـة العامـة للشركة وشركات الأثخاص، طبعة ؛ 99 1،

$$
\text { بدون دار نشر. }
$$

ـ الشركات متعددة الجنسيات، بدون سنة، بيروت، المؤسسة العامـة للاراسـات

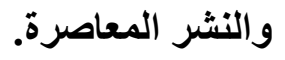

9 ا ـ دـ حسن كيرة، أصول القانون، الطبعة الأولى، منشأة المعسارف، الإسكندرية،

• ץ - د. حسين عامر، التعف في استعمال الحق و إلغاء العقود، الطبعة الأولى، مطبعة

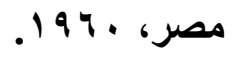

آ ـ د.جورجيت صبحى عبده قليني، مبدأ استقلال التوقيعات في الأوراق التجارية،

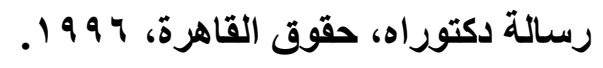

ب r- دـ خليل فيكتور تـادرس خليل: مبدأ الاستقلال في خطاب الضمان الدولي وفقاً

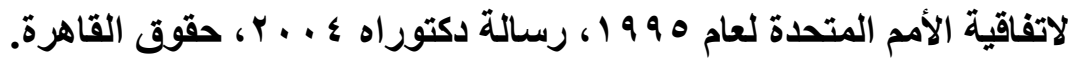
ب r - د. دريد محمود على، الثركات المتعدة الجنسية، آليات التكوين وأساليب النشاط.

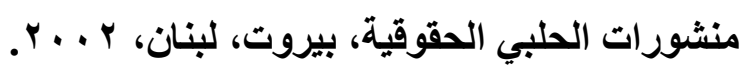


צ ץ ـ دــ راجح فؤاد السيد مصبح، التحكيم في الأوراق التجارية، دراسة مقارنـة، رسـالة

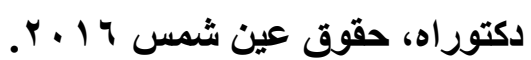

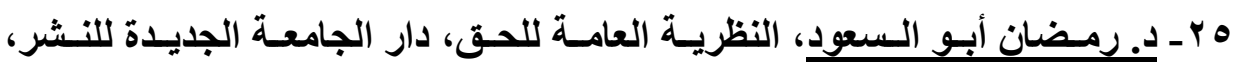

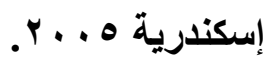
צ Y - د. رضا السبي عبدالحميد:

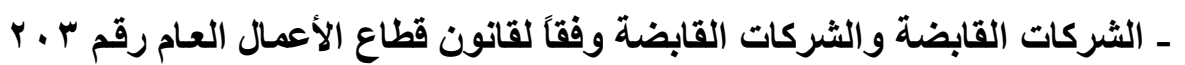

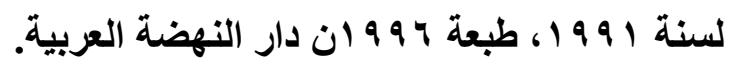
ـ مسكائل في التحكيم ـ التحكيم في الكفالـة المـصرفية وخطسب الضمان، طبعـة

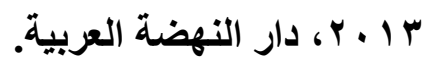

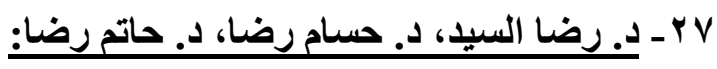
ـ الأوراق التجارية، طبعة ء 1 ـ ب، دار التهضة العربية. ـ قانون التجارة الجديد رقم V V لسنة 99 9 1 1، طبعة ه 1 ـ ب، دار النهضة العربية. ـ عمليات البنوك ذات الطابع الدولي، طبعة ـ 1 ـ ب، دار النهضة العربية. ـ النظام المصرفي وعمليات البنوك، طبعة 1 ـ ـ r، دار النهضة العربية.

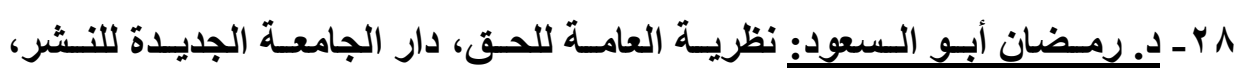

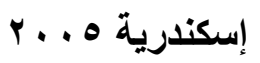




\section{Y - دـ. سميحة القليوبي:}

ـ الأوراق التجارية، طبعة ه ـ . . ب، دار النهضة العربية.

ـ المنظمـات الدوليـة، إتفـاقيتي الأمـم المتحدة في شـأن الكفـالات المستقلة وخطابـات

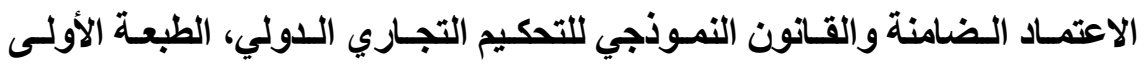

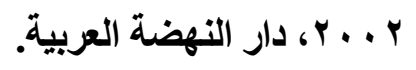

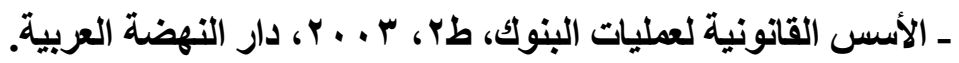

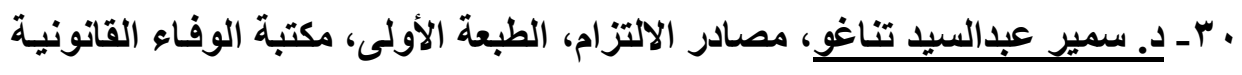

. . . 9

اس- دـ شـريف محمـد غنــام، مـدى مسئولية الشركة الأم عن ديـون شـركتها الوليدة

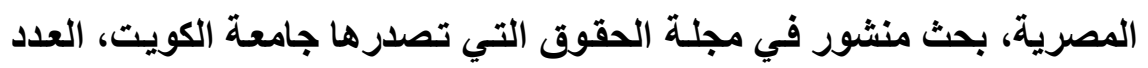

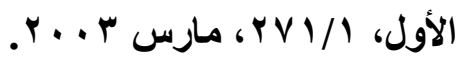

r r ـ د. طاهر شوقى مؤمن، التجمع المؤقت للمشروعات 1 ـ ـ r، دار التهضة العربية. r r- د. طلعت محمد دويدار، طرق التنفيذ القضائي، منشأة المعارف، إسكندرية، بدون تاريخ.

ع ץ- دـ. عادل إبر اهيم السيد مصطفى، مدى استقلال التزام البنك في خطابـات الضمان

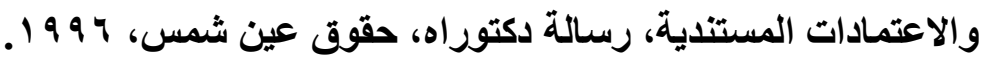

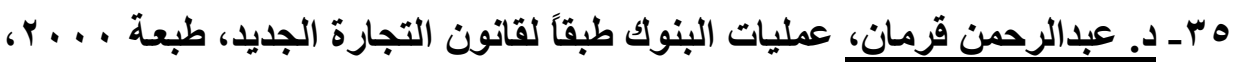
دار النهضة العربية. צ - د. عبدالحى حجازي،

ـ 190V 19 V العندات الائتمان الصرفية (الأوراق التجاريـة) الجزء الأول، القسم العام

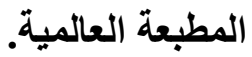




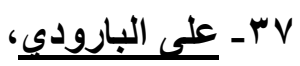

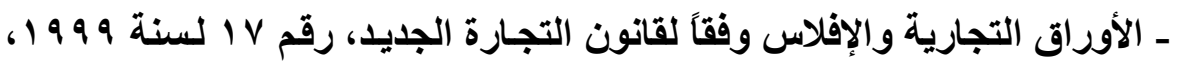

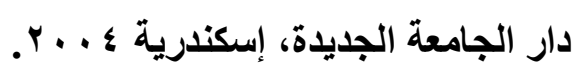

ـ العقـود وعمليـات البنـوك التجاريـة، طبعة ا ـ ـ ب، دار المطبوعـات الجامعيـة،

$$
\text { الإسكندرية. }
$$

ـ الأوراق التجارية والإفلاس وفقاً لقانون التجارة الجديد، رقم V V لسنة 999 19

$$
\begin{aligned}
& \text { دار الجامعة الجديدة، إسكندرية ؛ . . ب . } \\
& \text { אזـ ــ. على جمال الدين عوض: }
\end{aligned}
$$

ـ الاعتمـادات المستتدية، دراسـة قانونيـة للأعـراف الدوليـة، طبعـة اله 9 ا، دار

$$
\text { النهضة العربية. }
$$

ـ الاعتمادات المصرفية وضماناتها، ؛ 9 ـ 1، دار النهضة العربية، القاهرة.

$$
\text { q ب- د. على سيد قاسم: }
$$

ـ قانون الأعمال، الجزء الثالث، ط ؛ ، دار النهضة العربية.

ـ شرط التحكيم ومجموعة الشركات، المؤتمر 9 الجامعة الأمسارات عن التحكيم

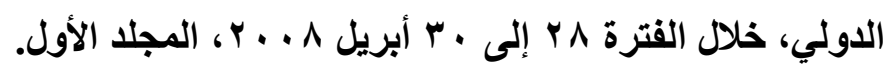

$$
\text { • ـ ـ د. على حسن: الثركات التجارية ه0 19 1 ، دار الفكر العربي. }
$$

اءـ ـــ عزمى عبدالفتاح، قواعد التتفيذ الجبري في قانون المرافعات المصري، طبعة I . . . د، دار النهضة العربية. 
ب ـ ـ د. علاء الدين محمد حمدان، التعاقد مـع الإدارة عن طريق الكونسورتيوم، مجلة

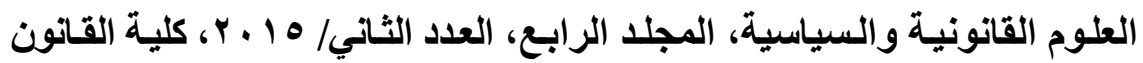

$$
\text { والعلوم السياسية، جامعة ديالي. }
$$

ب ع ـ دـ فايز نعيم رضوان:

ـ المشروعات الفرديـة ذات المسئولية المحدودة، طبعة ـ 99 19، مكتبـة الجـلاء الجديدة بالمنصورة.

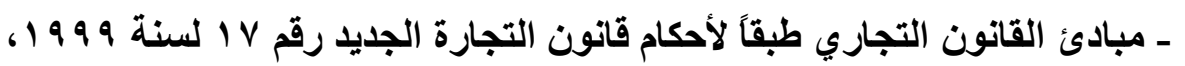

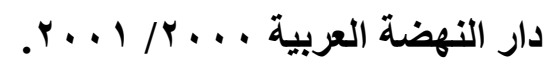

$$
\text { ـ الأوراق التجارية، 99 19 1، بدون دار نشر. }
$$

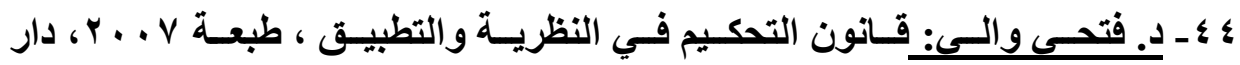

$$
\text { المعارف، الإسكندرية. }
$$

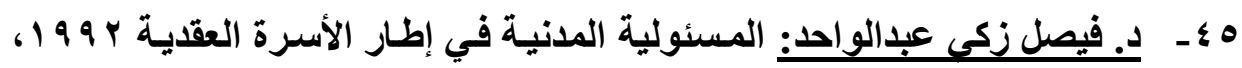

$$
\text { دار الثقافة والنشر، القاهرة. }
$$

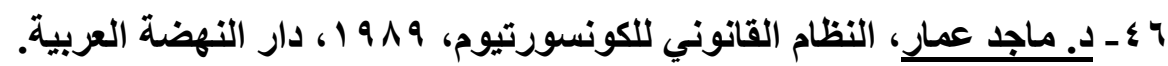

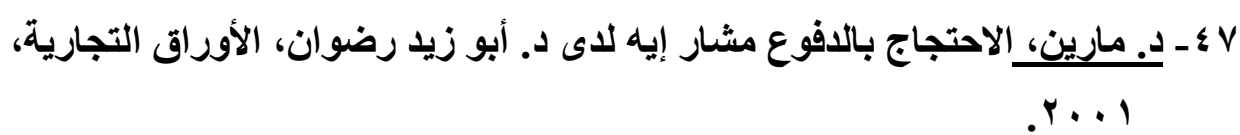

^ ـ ـ دـ مجدي عبدالفتاح، الامتناع المشروع للبنوك عن الوفاء بقيمـة خطاب الضمان (دراســة نقديـة لنظــام خطــاب الـضـمان)، رســالة دكتـور اه، حقـوق عــين

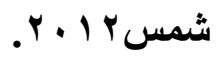




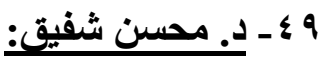

ـ المشروع ذو القوميات المتعددة من الناحية القانونية، مجلة القانون والاقتصاد،

كلية الحقوق- جامعة القاهرة، 19 VV

ـ المطول في الأوراق التجارية ال19 19، بدون ناشر.

• • المستشار محمد إبراهيم خليل، قانون التجارة الجديد وأعمالـه التحضيرية، نـادي .

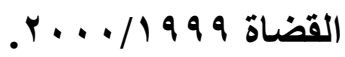

1 - 1 - د. محمد بهجت فايل،

ـ الأوراق التجارية، الطبعة الأولى 9 ، . . ، دار النهضة العربية.

ـ شركة الثخص الواحد، الطبعة الأولى • 99 1، دار النهضة العربية.

r ه ـــ محمد حبيب معاذ: الفش البحري، مجلة الرائد العربي، العدد ؛ 1 السنة الرابعة

.1919

به ـ د. محمد سـليم العوا، قانون التحكيم في مصر والدول العربيـة، ؛ ا ـ ب، المركز العربي للتحكيم.

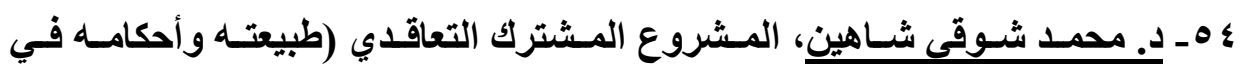

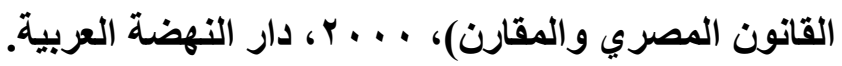

هـ ـ د.محمد صالح بك، الأوراق التجارية . . 9 1، مطبعة جامعة فؤاد الأول.

צه - د. محمد فريد العريني، د. على البارودي:

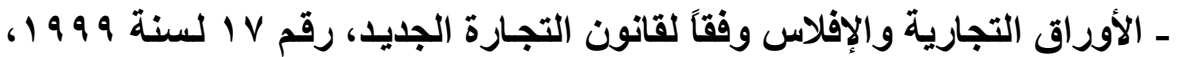

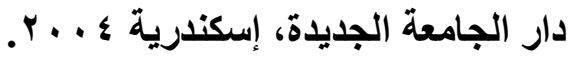

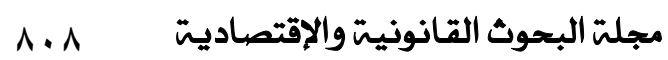


ـ الشركات التجارية، طبعة 999 19 ، دار الثقافة الجامعية الإسكندرية.

V ه ــ مـصطقى سـلامة حسن، التنظيم الـدولي للشركات متعـددة الجنسية، طبعة r r 19 1، دار النهضة العربية.

$$
\text { 10 - د. مصطقى كمال طه: }
$$

ـ العقود التجارية وعمليات البنوك وفقاً لأحكام قانون التجارة رقم VI ل لسنة 99 9 9 1،

$$
\begin{aligned}
& \text { طبعة r . . ץ، دار المطبوعات الجامعية الإسكندرية. }
\end{aligned}
$$

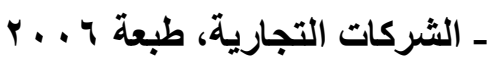

9ه ــ دـ محمـود أبو وافيـة، التصرف القـانوني المجرد، رسـالة دكتوراه، جامعة فؤاد الأول طبعة V \ 9 1، مطبعة جامعة فؤاد الأول.

$$
\text { • } 1 \text { - د. محمود سمير الثرقاوي: }
$$

ـ الأوراق التجارية في قانون التجارة الجديد، تنقيح وائل بندق طبعة ؛ 1 ـ ب، دار

$$
\text { النهضة العربية. }
$$

ـ المشروع المتعدد الجنسيات والثركة القابضة كوسيلة لقيامسه، بحث منشور في

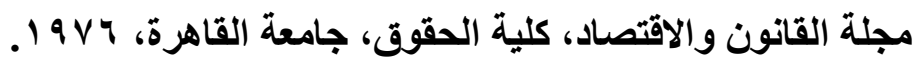
ا 1 ـ د. محمود عمر: إثكالية امتداد شرط التحكيم بالتطبيق على قضية هضبة الأهرام،

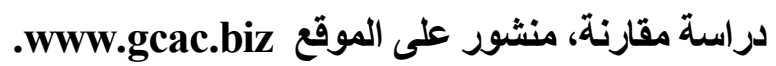

\section{با - د. محمود مختار بريزي:}

ـ التحكيم التجاري الدولي، طبعة 999 19، دار النهضة العربية.

ـ قـانون المعـاملات التجاريـة، الجزءء الثـاني، الإفـلاس والأوراق التجاريـة، طبعـة

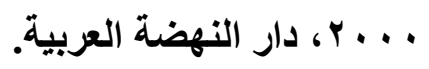


با - دـ محى الدين إسماعيل علم الدين: موسوعة أعمال البنوك من الناحية القانونية، 9 AV

ـ 7 - د. ناجى عبدالمؤمن، النظرية العامة للشركات التجارية، طبعة ه 1 ـ ب، دار نصر للطباعة.

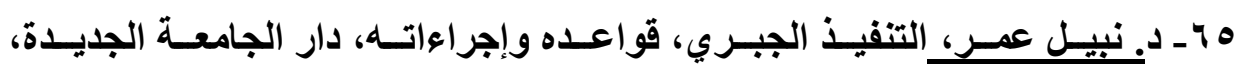

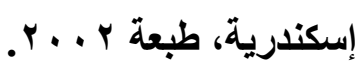

צ 7 - د. هانى محمد دويدار العقود التجارية والعمليات المصرفية، ؛ 9 و 1، دار الجامعة الجديدة للنشر، الإسكندرية.

V V - د. هانى صلاح سري الدين، اتفاقـات الكونسورتيوم، الطبعة الأولى 999 19، دار النهضة العربية.

1 - - د. هند محمد حسن: ـ مدى مسئولية الشركة الأم عن ديون شركاتها الوليدة في مجموعة الشركات، مع

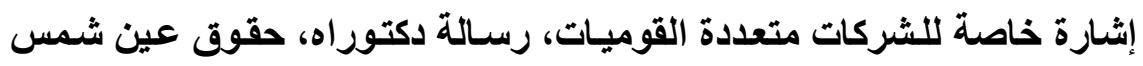
$.199 \mathrm{~V}$ ـ النظام القانوني للشركات متعددة الجنسيات، طبعة 9 . . ب ، دار شتات، مصر. 9 7 - دــ وجدي راغب النظريـة العامـة للتنفيذ القضائي في قـانون المرافعـات المدنية

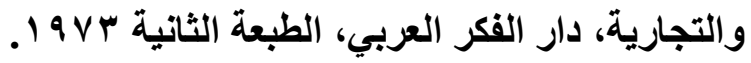
• - د. يوسف نـاعس، حجز ما للمدين لدى الغير، مجلة المحامون، نقابة المحامين،

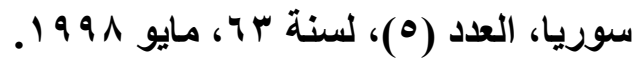




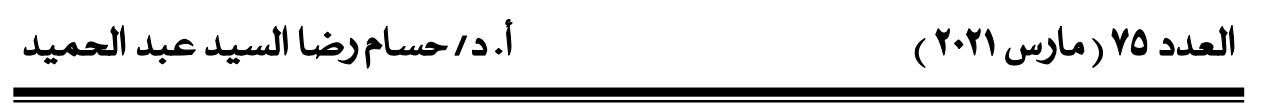

ا - يوسف بنباصر، 》اماهية الغش في الاعتمـاد المستثدي/ على الموقع الإكترونسي .benbaceryousef@meneara.ma

V - مقال بعنوان: كمبيالات المجاملة وأثرها على الائتمان والتداول التجاري، منشور

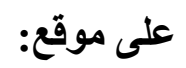

http://www.mohamoon/montada/default.aspex?action=Display

$$
\begin{aligned}
& \text { ثانياً: المراجع الأجنبية: } \\
& \text { 1ـ الكتب والمقالات: }
\end{aligned}
$$

(1) Azencot, F. la protection de porteurs d'obligations. L. G. D. J. Paris 1939.

(2) Buttet, E, Groupement d'intérêt economique, Bull. Joly 1989, p. 855 et ss;

(3) CABRILLAC M., la letter de change dans la jurisprudence, librairies techniques, 1978, p. 17 etss.

(4) CHAMPAUD Claude. Le pouvoir de concentration de la societé - par action, Librairie sirey, Paris 1962 p. 243 : 317.

(5) Cohen D. Arbitrage Et Société, Preface, R. Oppétit. L. G. B. J. 1993.

(6) Escarra, manuel de droit commercial T. 2. 1948, p. 676.

(7) Frederic magnas, les groups de société et la protection des interest catégoriele, sur le site. www.academia.edu. 
(8) FRIEDEL G., de l'inopposabilité des exceptions en matiere d'effets de commerce, Paris 1950.

(9) Gavalda et j. stoufflet

- Cheques et effets de commerce, Paris 1979.

- Chr. Dr. Bancaire, J. C. P. 1986, et. G. 1.3265 nº 121.

(10) Huxinyu, le groupe de sociétés en droit francais et en droit chinois, thése Angers, France 2010.

(11) Kanan Kh., fraude cohesion IBLJ. No. 6.

(12) Loquin Eric, difference et convergence dans le regime de la transmission et de l'extension de la clause compromissoire, les cahiers de l'arbitrage, vol. 2, p. 49;

(13) MAYER, Pierre les limites de la séparabilité de la clause compromissoire, Rev. arb. 1998. p. 359 etss.

(14) NIOREL, la societé anonyme devant la jurisprudence moderne, Thése Nancy.

(15) PRUM Andre application de l'adage "fraus ommia corrumpit" à propos des garanties à première demande, reflexions sur l'arrêt de la cour de cassation française du 10 Juim 1986; D. P. C. I 1987, t. 13. 
(16) Seraglini Ch., le transfert de la clause compromissoire dans les chaines de contrats, après l'arrêt peavey, les cahiers de l'arbitrage, vol1, P. 87.

(17) Thaller et Percerou,

- Nature Juridique du titre de crédit. Ann. Droit commercial 1906. no 60 etss.

- Traité élémentaire de droit commercial Paris 1931. t. 2.3 p. 807.

(18) Tyssie B. les groups de contrats, L. G. D. J. Paris 1979, Preface, P. Catala.

(19) Vallez, quell est le fondement de l'obligation engendrée par l'acceptation d'une lettre de change, Ann. De dr. Com. 1923p. 180 etss.

(20) VASSEUR,

- Droit et economie bancaire, Paris 1987, p.284.

- Filiales et participation fasc. 165 bis du traité jurisclasseur des societés.

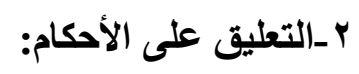

(1) Paris 22 mars 1995, Rev. arb. 1995, 247. obs. E. loquin; Cass. Civ. 6 fevr. 2001, Rev. Arb. 2001. 1135, note, D. Cohen. 
(2) Cass. Civ. 27 mars 2007, D. 2007 Jun, 2077 note S. Bolle (láffaire ABS/ AGF).

(3) Sentence arbitral, c. C. I du 23 sept. 1982, Rev. Arb. 1984. 137.

(4) Cass. Com 17 Janvier 1983., J. C. P. 1983. 11-19966 note J. Stoufflet.

(5) cass. Com. 20 Nov 1985, Dalloz 1986, J. 213.

(6) Cass. Com 19 nov. 1985 Bull civ IV no 274, p.231. Cass. Com 5 Fev. 1985, Bull, Civ IV no 45 P. 38; Cass. Com 20 nov. 1985, Dalloz 1986. J. 213, 3em esp, note vasseur; Gavalda et stoufflet, chr. Dr. Bancaire, J. C. P. 1986, et. G. 1. 3265 no 121.

(7) Cour d'appel de Pairs 14eme ch. 12 Juin 1985 Banque 1986, 190 ob. Rive - Lange.

(8) Cour d'appel de Paris 14eme ch. 12 Juin 1985 banque 1986, 190 ob Rive - Lange.

(9) Cass. Com. 29 aur. 1986. D, 1987, P. 17, 20 note VASSEUR; -Cass. Com. 10 Juin 1986, Rev. Banque 1985, p. 92; (210) Cour d'appel 14eme ch.12 Juin 1985, Banque 1986, 190 obs. Rive - Lange; - Cass. Com. 21 mai 1985, Banque 1986. p. 
أ. د/ حسام رضا السيد عبد الحميد

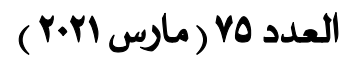

87; - Cass. Com. 120 Janvier 1987, J. C. P. Ed. (E) 1987, 11. 14882. ob. J. Stoufflet.

(10) Cass. Com. 21 Mai 1985, Banque 1986. 87 note Rive Lange; Dalloz 1986, J. 214 obs. VASSEUR.

(11) Cour d'appel de Riom, 14 Mai 1980, Dallez 1981, 36 obs. VASSEUR. 